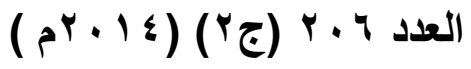
مجلة دراسات في المناهج وطرق التدريس

برنامج لتنمية كفايات النقد الأدبي لاى طلاب شعبة اللغة العربية بكليات التربية في ضوع نظرية التَّقِي

\author{
إعـداد \\ د / سيد محمد السيد سنجي \\ أستاذ مساعد مناهج وطرق تدريس اللغة العربية والدراسات الإسلامية \\ بكلية التزبية جامعة بنها
}

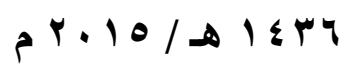


برنامج لتنمية كفايات النقد الأدبي لاى طلاب شعبة اللغة العربية بكليات التربية في ضوء نظرية

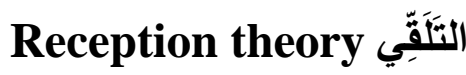

د / ميد محمد السيد سنجي

المقدمة والإحساس بالمشكلة :

تبرز أهمية الأدب لما له من دور بارز في مساعدة المتلقي على الشعور بالمتعة الفنية، والسمو بالذوق الجمالي، وبعث السرور النفسي، والاتصال بالمثل العليا في الأخلاق، وزيادة الحصيلة اللغوية، وتوسيع أفقه الثقافي، والانفعال بالآثار و التجارب الإنسانية الر ائعة التي تنعكس في لون من

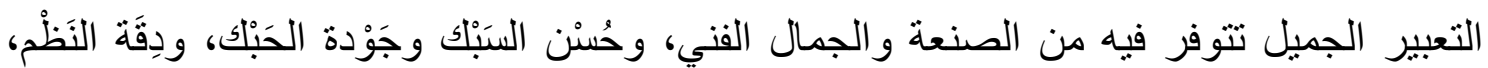

وسمو المعنى، وروعة التصوير، و الخيال المبتكر ، والعاطفة النبيلة، و الموسيقا المؤثرة. ومن ثن، فالأدب لا يتأتى له أن يؤثر في المتلقي إلا إذا اكتملت له تللك المقومات الفكرية و الجمالية و العاطفية و الفنية، كما أن المتلقي لن يستطيع التفاعل معه تقديرًا و إنتاجًا إلا إذا كان

متمكنًا من كفاية مهمة تسمى "بالنقد". و هذا يؤكد العلاقة الوثيقة بين النقد والأدب، فالنقد هو الذي يكثف أصالة الأدب وعدم أصالته، ويميز بين جيده ورديئه، وسواء أكان النقد عِلْمًا أم فَنَاً فإنه ليس قائمًا بذاته، و إنما هو متصل بالأدب، يستمد منه وجوده، ويسير في ظله يرصد خطاه واتجاهاته (رسلان، ه ... ؟،

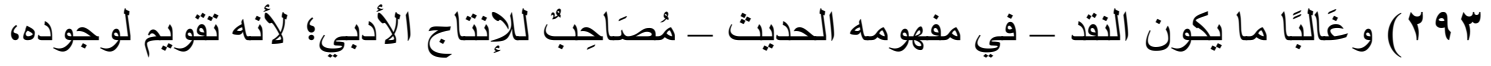
وقد يدعو النقد إلى إنتاج جديد، في سماته وخصائصه فيسبق ما يدعو إليه من أدب، بعد إفادةٍ وتَمَثُلٍ للأعمال الأدبية والتيار ات الفكرية العالمية؛ ليوفق بدعوته بين الأدب ومطالبه الجديدة في العصر

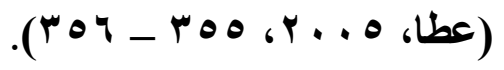

ومن ثم فالنقد نشاطٌٌ إبداعيٌ مثله مثل الأدب، و إذا كان الأدب إبداعًا تركيبيًا، فالنقد إبداعُ تحليليٌ، ولا غنى عن الحوار بين الطرفين، إذ لا يقوم نقدٌ مبدعُ إلا بوجود أدبٍ مبدعٍ، ولا يتطور

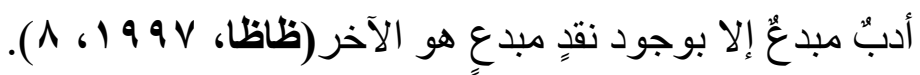
والنقُّ الأدبيُ "جُزْهُ من النقد العام يهتم بالظاهرة الإبداعية في أقانيمها الثلاثة [المرسل، و الرسالة، و المرسل إليه، أو الكاتب، والنص، و المتلقي]، ويدور حولها ويوليها عنايته، يفحصها

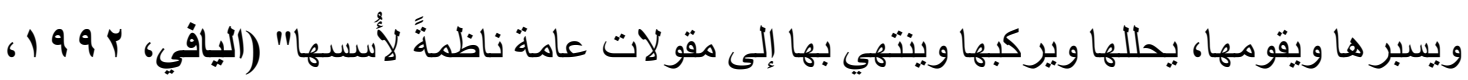




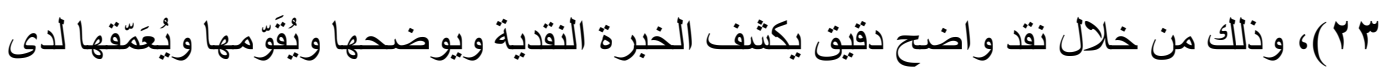

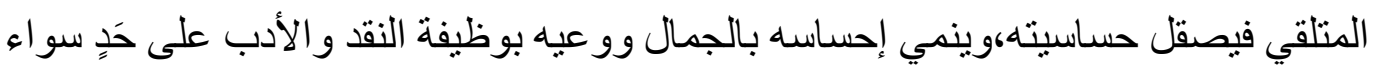

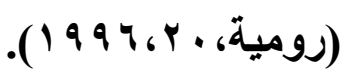

وعلى ذلك، فقد تركزت اهتمامات النقاد على أركان الإبداع الأدبي الثلاثة منذ نثأة النقل،

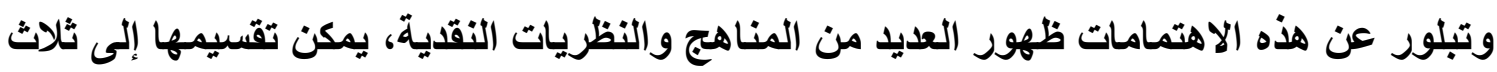
مراحل، هي: أــ مرحلة المؤلف (سلطة المؤلف وهيمنة السياق): حيث اهتم النقد في هذه المرحلة بدر اسة العمل

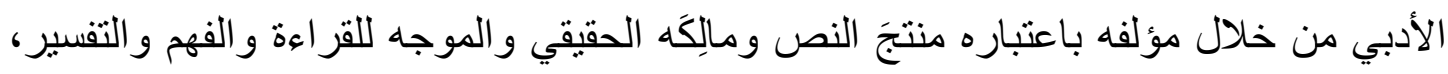

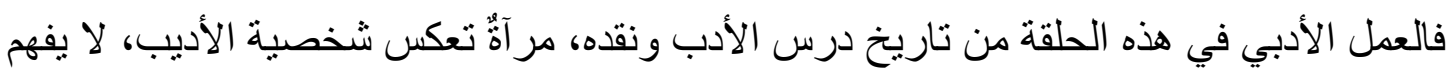

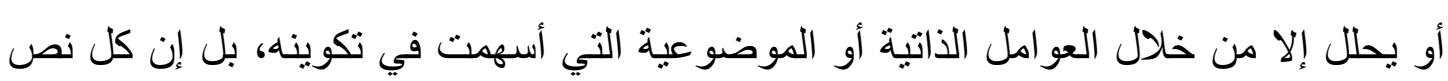

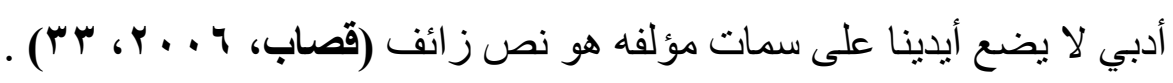

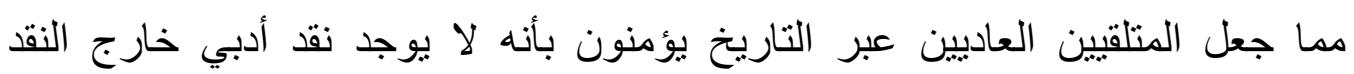

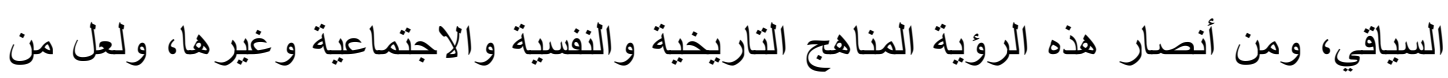

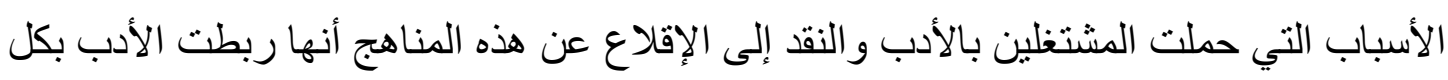

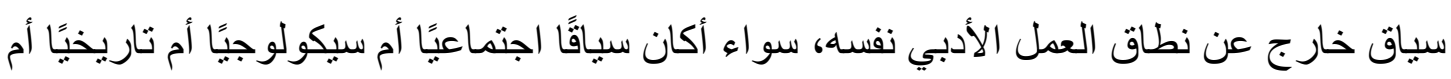

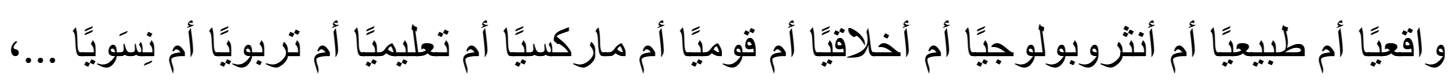

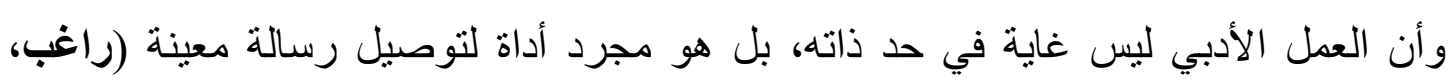

$$
\text { . (rq. . r..r }
$$

ب ـ مرحلة النص (سلطة النص وهيمنة النسق): وقد اهتم النقد في هذه المرحلة بالتركيز على ). أدبية النص، وأن النص ليس أدبيا بمعناه أو فحو اه، و أنه ليس كذللك من حيث الئ نشأته وما يتندخل

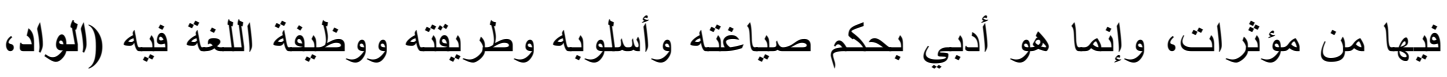
ه191 ( ، 7 7)، ولذا فقد كان شعار النقد في هذه المرحلة "موت المؤلف أو اختفائه"، ومن أنصار

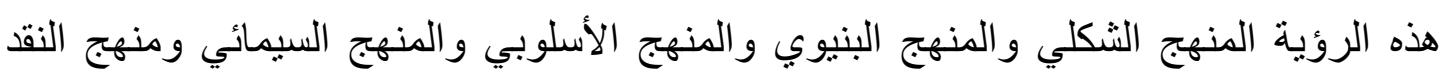

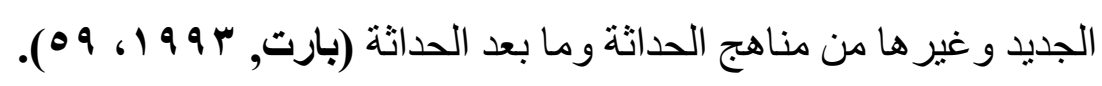

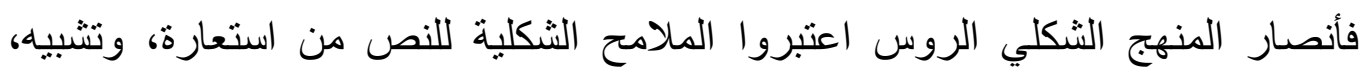

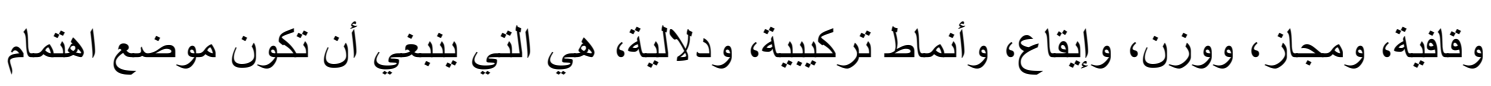


الناقد أو القارئ. وبناء عليه فرقوا بين اللغة الأدبية واللغة العادية، بل قالو ا: إن اللغة الأدبية يجب التبا

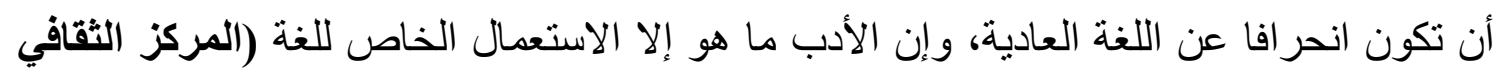

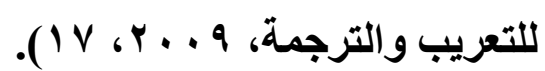
كما نادى رواد منهج النقا الجديد بضرورة فصل تحليل النص عن ذاتية المؤلف والناقد معا، فمن النص الانطلاق و إليه الوصول، دون اعتبار لقصدية الناص و المتلقي (حمودة ، 9191 1،

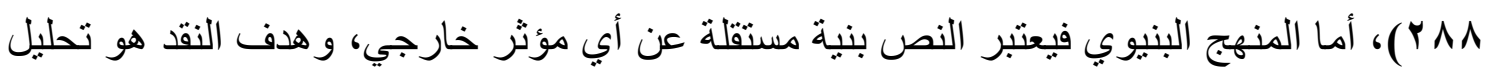
هذه البنية والكثف عن قو انينها الحاكمة لها وذلك وفق منهج واضح يحلل الأجز اء اللسانية تحليلا

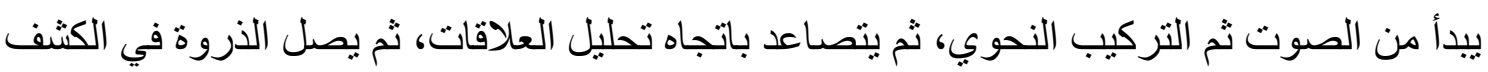

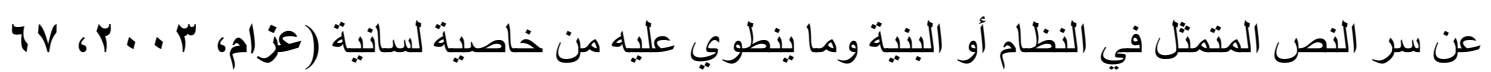

ويركز النقد السيمائي على الكثف عن الكيفية التي يتشكل بها المعنى داخل النص الأدبي

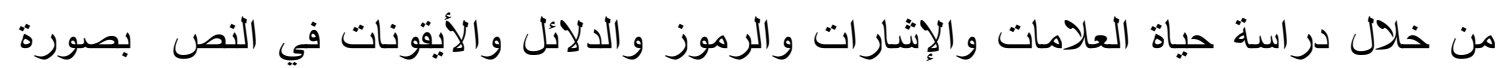
منظمة منتظمة ودور ها في تحقيق المعنى، فلا يهمه المضمون، و لا قائل النص، بل يهمه كيف قيل

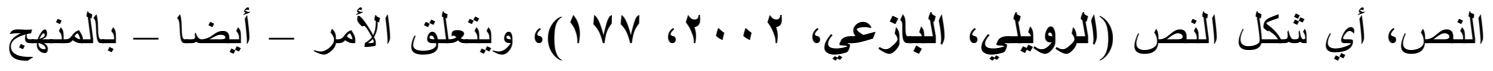

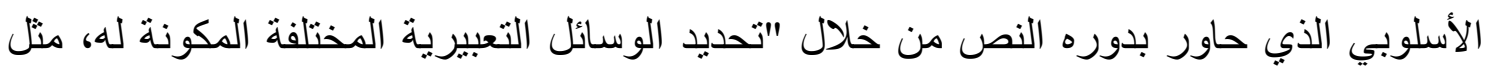

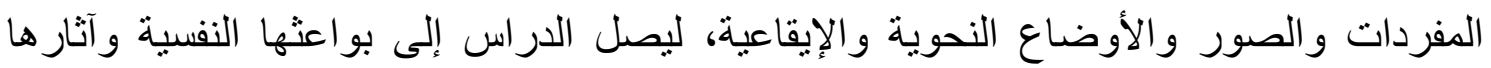
الجمالية، فالأسلوبية تحاول الإجابة عن السؤال: كيف يكتب الكاتب نصا من خلال اللغةّ؟ إذ بها

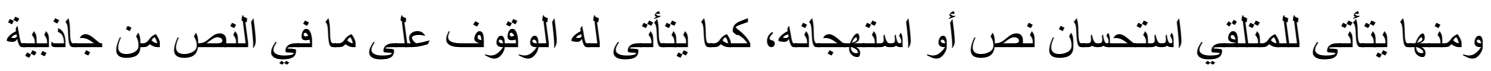

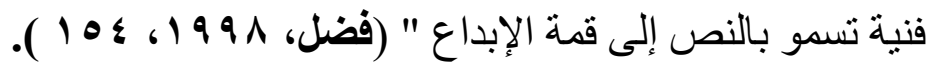

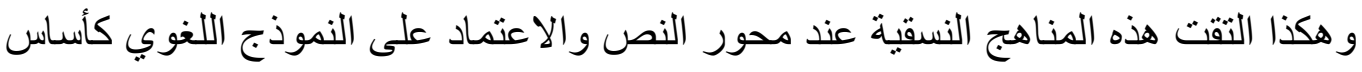

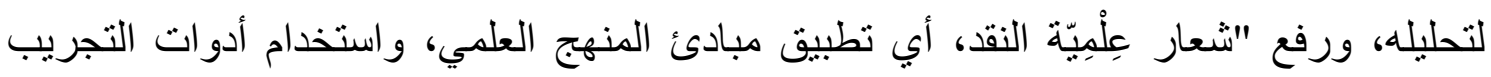

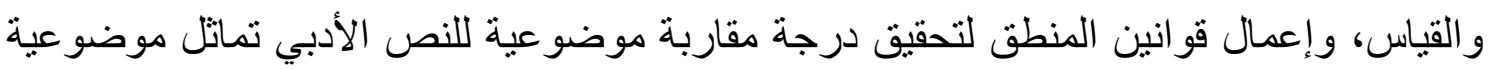

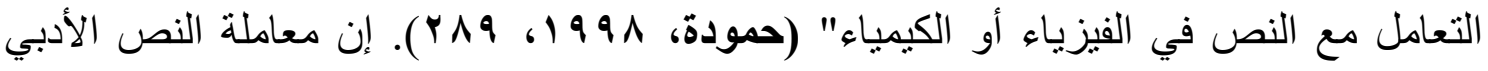
كمادة تجرييية يمكن إخضاعها ــ دائما ـ لقو انين وقو اعد عامة تحكم النصوص اللغوية، هي عملية لا تؤدي فحسب إلى تجاهل الذات المتكلمة، و التضحية بمضمون الأثر، و إهمال هوية النص الأدبي وخصوصيته، بل إنها - كذللك - تسمح بإككانية أن يكون أي نص أدبي موضو عا أو مادة تجريبية 
للانقا وإن كان ضئيل القيمة، ما دام الهدف لم يعد هو النص في ذاته و إنما التناول المنهجي أو

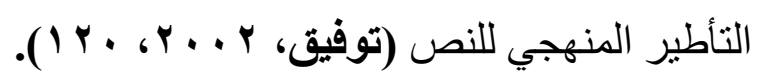

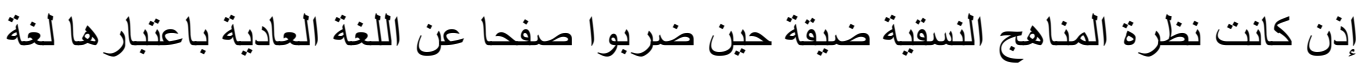

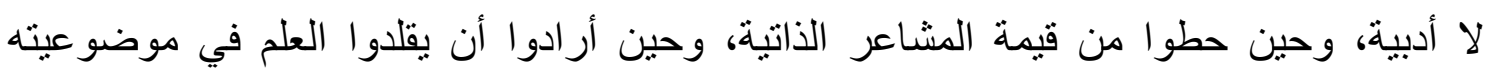

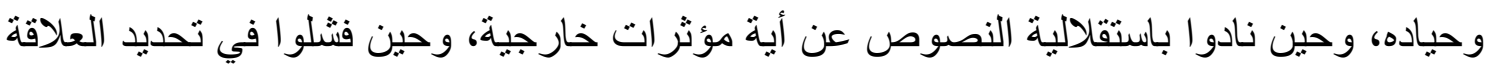

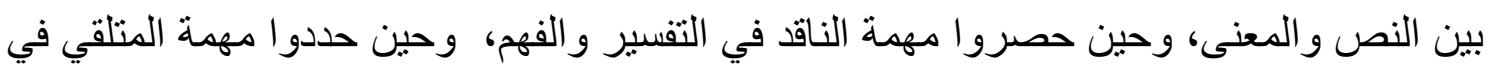
الحصول على المعنى الجاهز الذي يقدمه له الناقد دون اعتبار لاستجابته العاطفية للنصوص، لكل

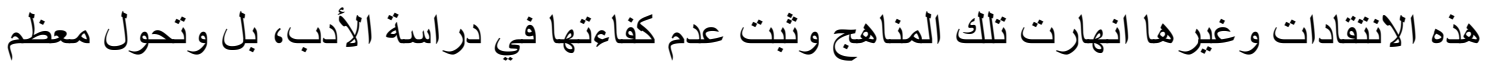
روادها عنها إلى مناهج نقدية أخرى لتجديد أدو اتهم النقدية (المركز الثقافي للتعريب والترجمة،

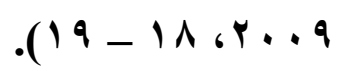

ج- مرحلة القارئ والمتلقى: وقد اهتم النقد في هذه المرحلة بإعطاء القارئ دور ا أساسيا عند تناول

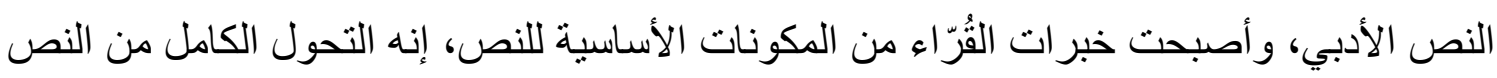
و المؤلف إلى القارئ والنص، فالنص لا يستمد وجوده وكينونته من مؤلفه و إنما يستمدها من القارئ،

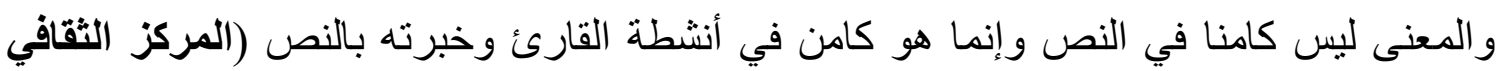

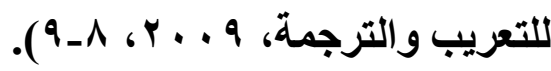
ولقد كان لهذا التصور الجديد لمكانة القارئ دوره في ظهور نظرية نقدية جديدة في الأدب هي لهي نظرية التلقي ، حيث كانت الانطلاقة في ستينيات القرن العشرين من "مدرسة كونستانس

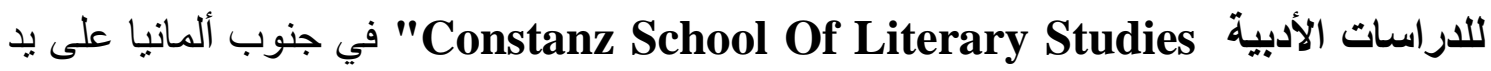
العالم "هانس روبرت ياوس Hanse Robert Jauss"، ثم تلاه في ذلك "فولفجاتج إيزرWolfgang Iser"؛ الذي تبنى آراء مو اطنه ياوس؛ لتوجيه الاهتمام إلى المتلقي بهذف كثف

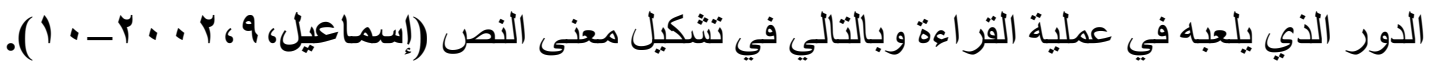
و اكتسبت هذه النظرية أهمية كبرى في العملية النقدية من خلال الافتراضات و المفاهيم الفريدة

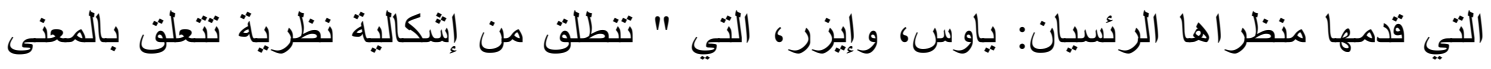

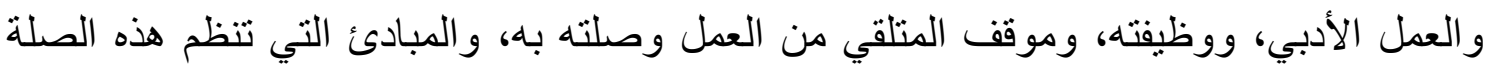

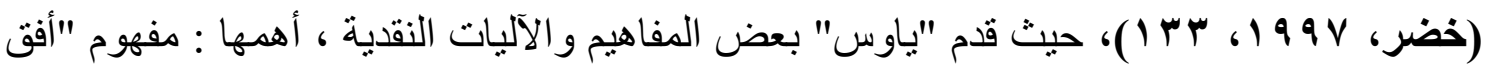


التوقعات Horizon Expectation" ، ومفهوم "الكسافة الجمالية Aesthic Distance" و المنعطف التاريخي ، و آلية السؤال و الجواب ، والتلقي المنتج.

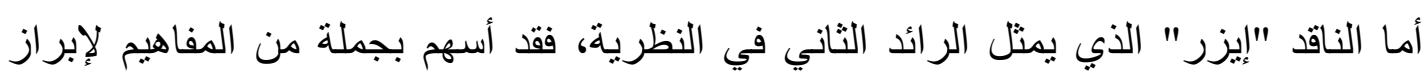

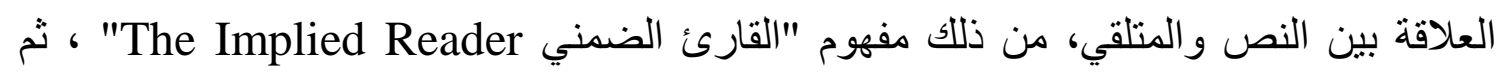

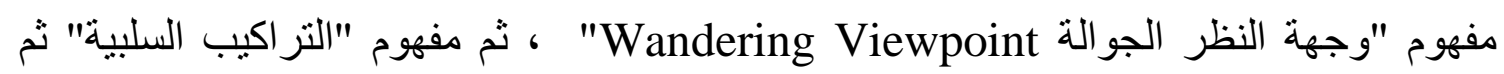
مفهوم "الفجوات Lacunas" ثم مفهوم "الاستر اتيجية".

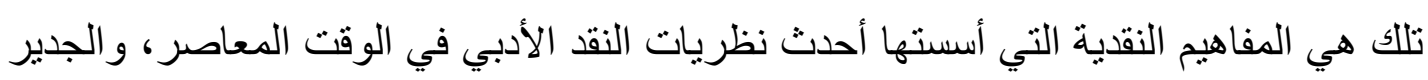

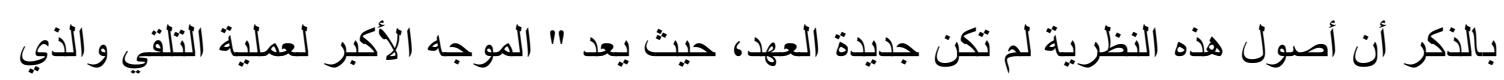

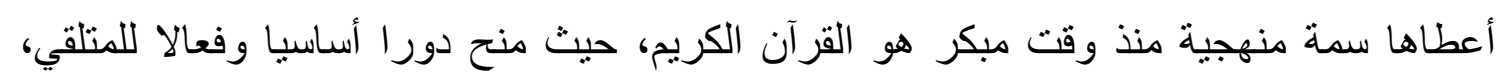

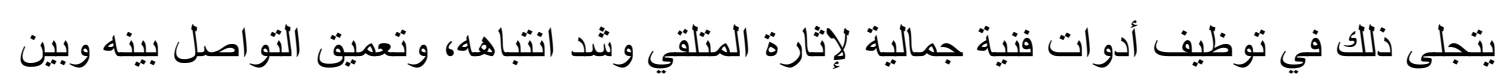

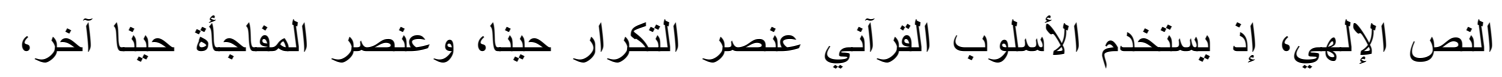

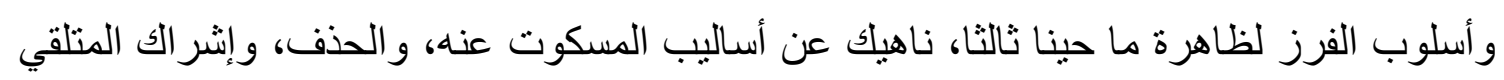
كعنصر أساسي في الاتصال عبر نوجيه الخطاب إليه مباثرة، وعبر دعوته له بالتفكر و التدبر في

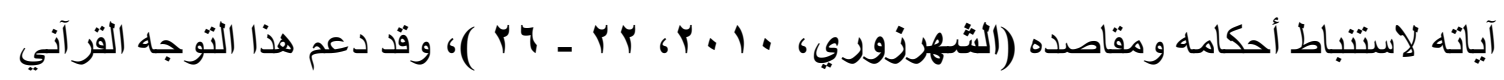
الحديث النبوي الثريف، فقد دعا النبي - صلى الله عليه وسلم ـ لعبد الله بن عباس - رضى الله

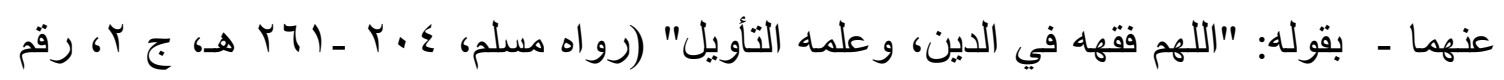

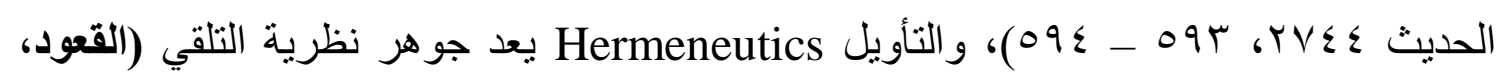

$$
\text { . (ra9، r. r r }
$$

وبالرجوع إلى تراثنا النقدي العربي القيم نجد احتفاء النقاد بدور المتلقي ، فقد اعتبره الجاحظ

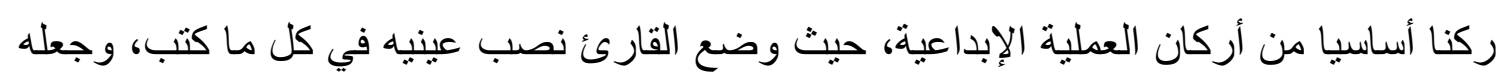

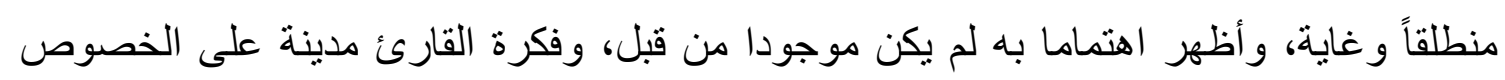

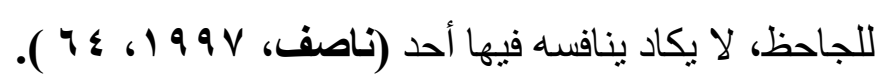

من هنا تبرز ضرورة تأهيل النقد القارئ لإنجاز عملية تلثي فعالة من خلال استثمار مفاهيم نظرية التلقي، كما تبرز ضرورة تضمين تلك المفاهيم في برنامج إعداد معلم اللغة العربية بكليات

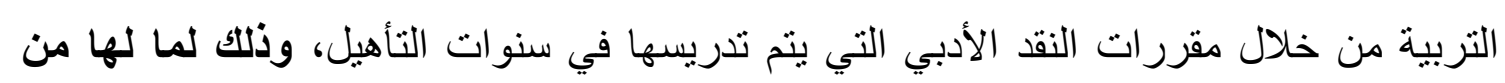
أهمية، يمكن تحديدها في الآتي: 
ـ تغيير دور الهتلقي في العمل الأدبي، من مستقبل سلبي إلى مستقبل إيجابي، قادر على فهم

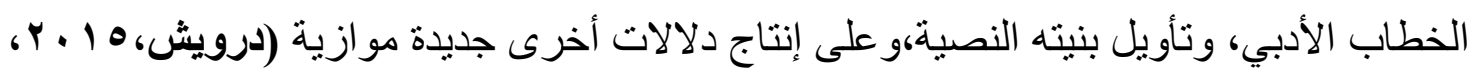

- إبراز أنماط التفاعل الأدبي بين بنية النص ومتلقيه، فالعمل الأدبي له قطبان، هما: القطب الفني،

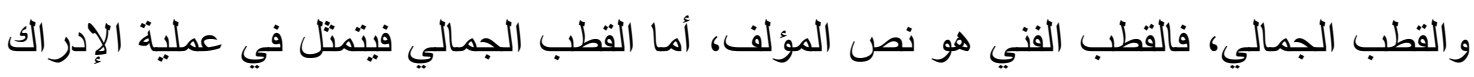

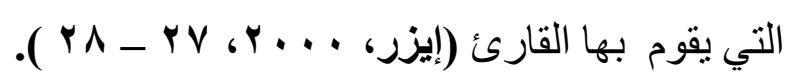

- إعادة تنظيم دورة العمل الأدبي باعتبار ها سيرورة تلقى وإنتاج جماليين، تتم من خلال تفعيل

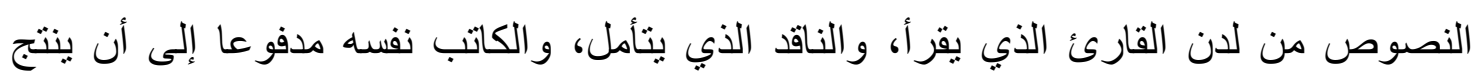

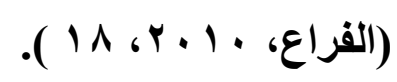

ـ تصحيح زوايا انحر اف الفكر النقدي لتعود به إلى قيمة النص وأهمية القارئ، بعد أن تهدمت

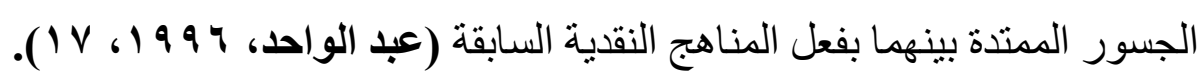
ـ نوظيف أفق نوقعات القارئ التي اكتسبها من خلال خبراته السابقة عن النوع الأدبي الذي ينتمي

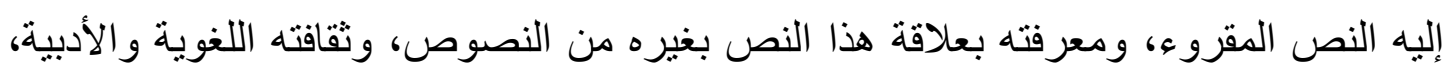
في قياس المسافة الجمالية للعمل الأدبي. ـ تتمية مهار ات التذوق لدى المتلقي باعتباره يعد من الأغر اض الكبرى لتندريس الأدب (يونس،

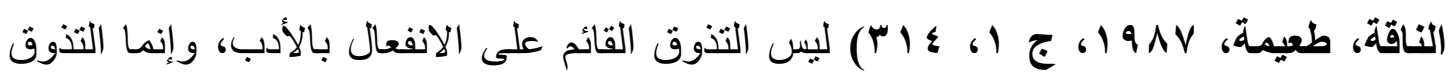

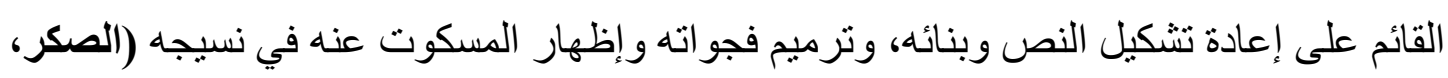

$$
\text { . ( } \mathrm{Y} \leq 6,1 \text {. }
$$

- إعادة تنظيم العلاقة بين عناصر الاتصال الأدبي [المؤلف، النص، المتلقي]، حيث لا تركز - فقط

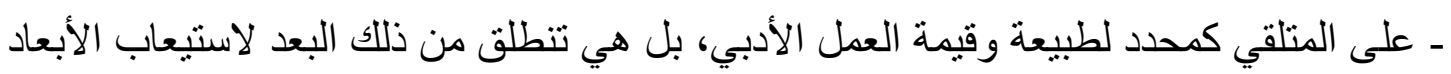

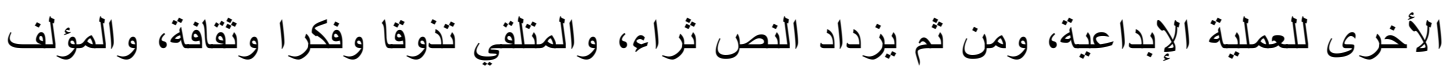

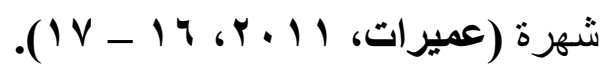

ـ احتو اء المناهج النقدية السابقة التي استنفدت جُل إمكاناتها و أدواتها، وتجاوز ها في الوقت نفسه

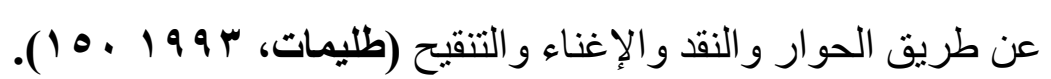

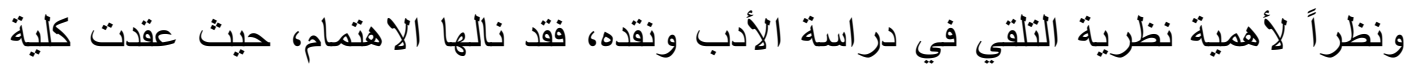

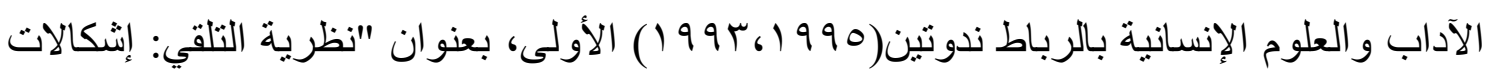


وتطبيقات"، والأخرى، بعنوان "من قضايا التلقي والتأويل"، وعقدأيضـاً مركز الخليل بن أحمد

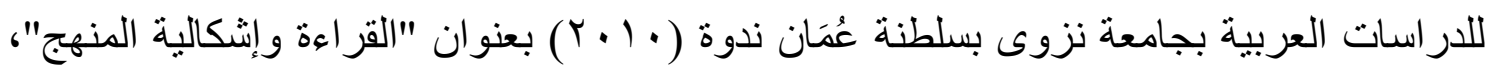

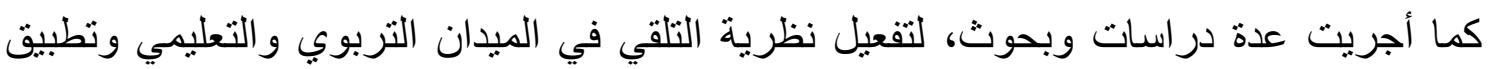
آلياتها وإجراءاتها في تدريس النصوص الأدبية وتتمية مهارات نقدها، منها: دراسة (حبيبي، ونسية

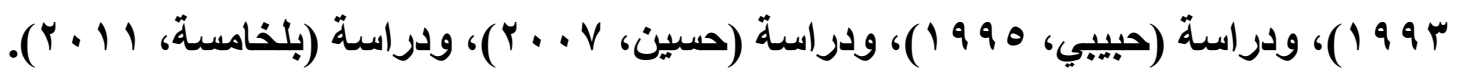

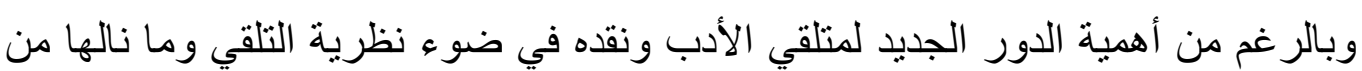
اهتمام، إلا أن هناك تدنيا في مستوى تمكن الطلاب المعلمين من الدفاهيم النقدية بصفة عامة،

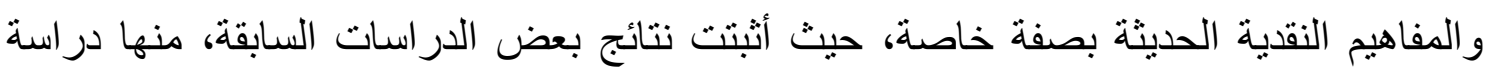
(رسلان، و99) أن درجة إلمام طلاب شعبة اللغة العربية ببعض كليات التربية في الوطن

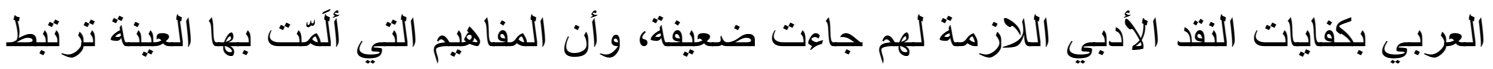

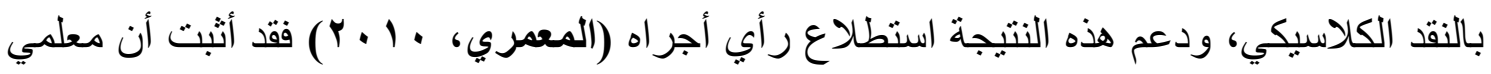
اللغة العربية في أثناء الخدمة ليس لديهم معرفة واسعة بادوات النده النقد الحديث التي تمكنهم من التفاعل

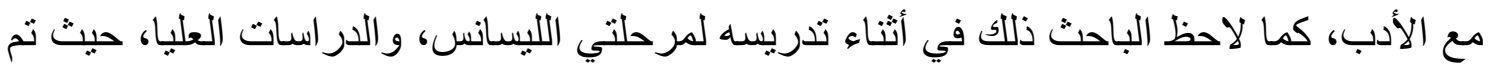

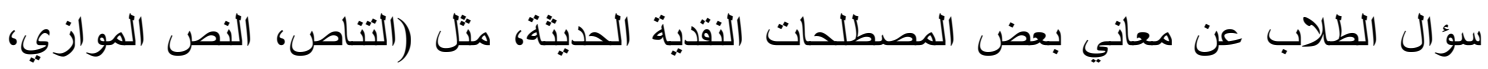
القارئ الضمني) فجاءت إجابات بعضهم خلافا للمقصود من الدصطلح، وأفاد بعضهم الآخر بجدَّها. ويُعَى ذللك التنني إلى العفوية والذاتية في اختيار الدقررات النقدية المقدمة للطلاب، وعدم وجود اتفاق على الكفايات اللازمة للطالب المعلم في مجال النقد الأدبي، وجمود المقررات بيرنامج الإعداد، و الانغلاق على مجموعة من مؤلفات النقاد الرواد الأو ائل أو التلخيصات المبتورة من هذه المؤلفات، دون الانفتاح على الاتجاهات النقدية الحديثة ومدارسها المتعددة (رسلان، هـ...ب، ץ ץ ץ)، بالرغم من انفتاح حركة الترجمة من أدبيات النقد العالمي المعاصر إلى اللغة العربية،

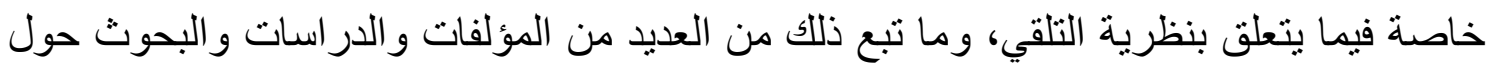

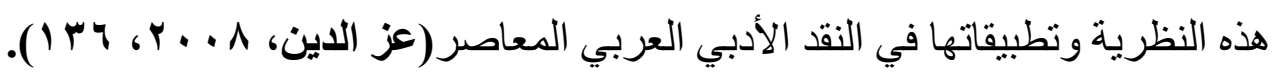

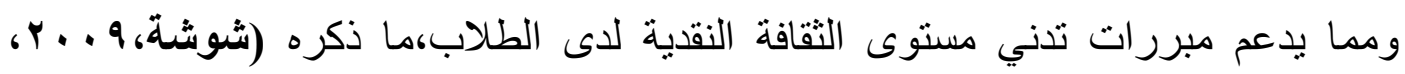
ه r 1 ) من أن المناهج التعليمية في المدرسة وفي كثثير من الجامعات تكرس الدفاهيم النقدية التقليدية في النظرة الجمالية إلى النص الأدبي،حيث الاهتمام بالمعنى لا بالدلالة أو الدلالات الملتبسة 
و المر او غة،فالا هتمام بالمعنى اهتمام بالساكن و الثابت و المؤطر ،و العجز عن اكتثاف تجليات الدلالة

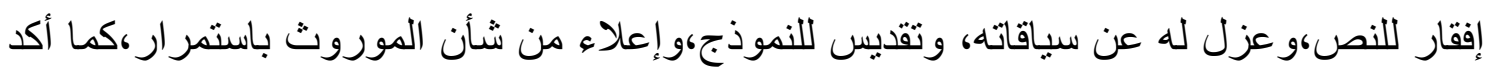

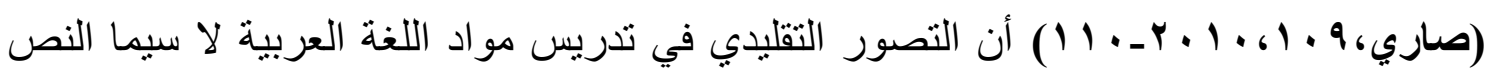
الأدبي هو السائد عموما بمراحل التعليم العام في الوطن العربي،وأن درجة الإفادة من المناهج

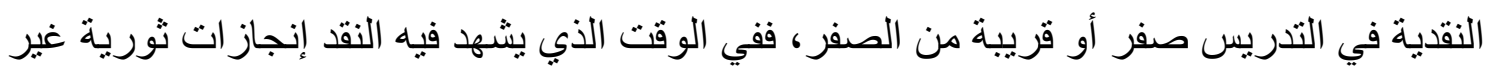

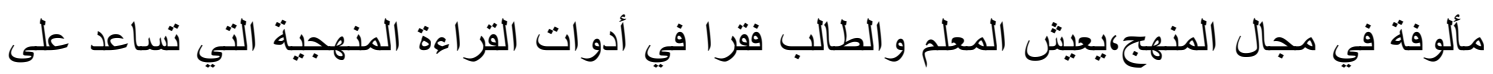

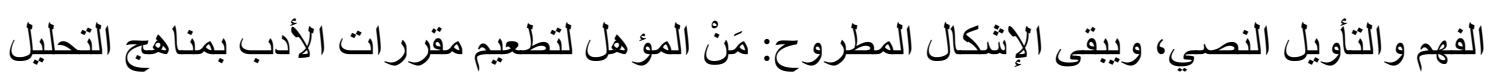
الحداثية؟ وكيف يحقق ذلك؟ بل كيف يُقنِع من يرفض النظريات الأدبية الحديثة أو بعاديها؟ وهل التكوين الذي تلقاه مدرس اللغة العربية يؤ هله لهذا التجديد؟.

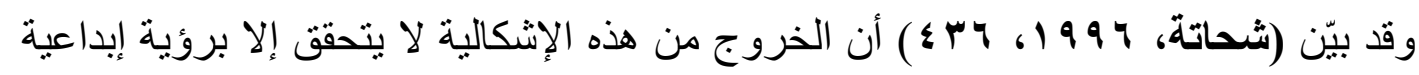

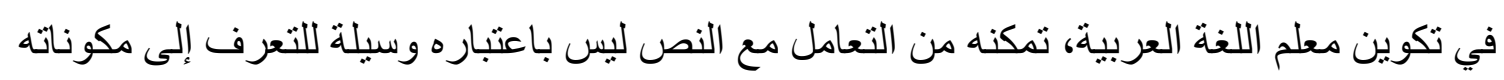

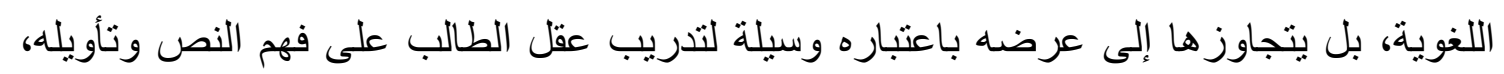

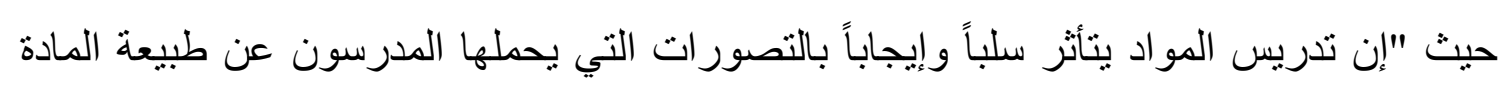

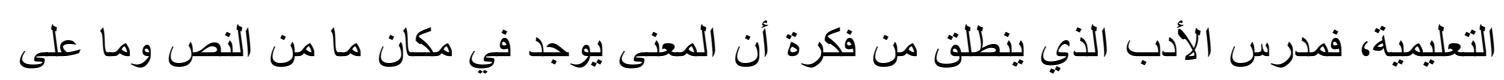

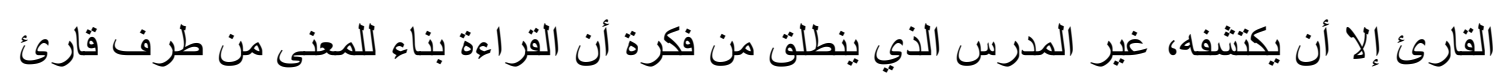

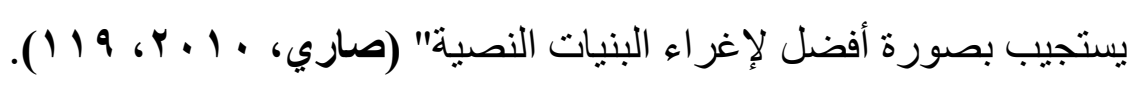

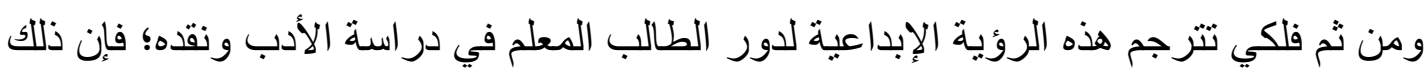

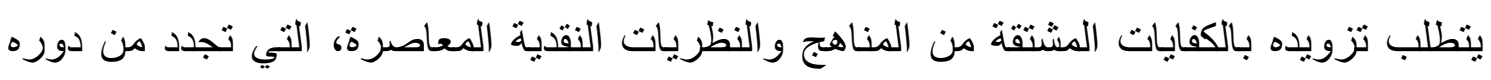
و أدائه في أثناء تفاعله مع النص من حيث هو " بناء لغوي ينطوي على تشكيلات رمزية ومستويات

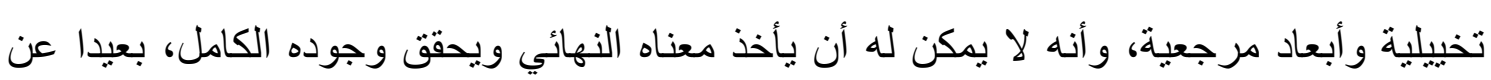

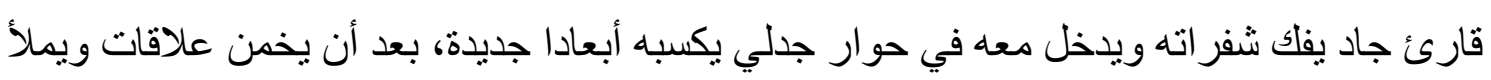

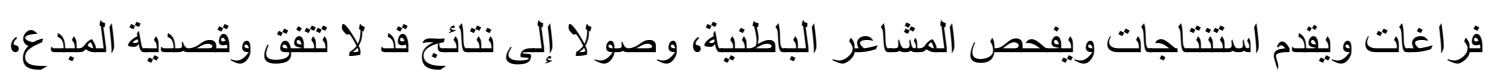

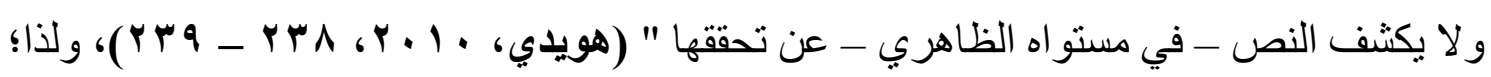
فقد تولد الإحساس بمشكلة الدر اسة الحالية لدى الباحث. 
تتحدد مشكلة الدر اسة الحالية في قصور برنامج إعداد معلمي اللغة العربية بكليات التربية

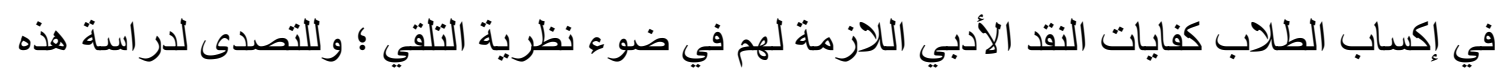
المشكلة ينبغي الإجابة عن السؤال الرئيسي التالي :

كيف يمكن بناء برنامج لتنمية كفايات النقا الأدبي لدى طلاب شعبة اللابئ اللغة العربية بكليات

التربية في ضوء نظرية التلقي ؟ باء برنج

ويتفرع عن هذا السؤ ال الرئيسي الأسئلة الفرعية النالية :

1- ما كفايات النقد الأدبي اللازمة لطلاب شعبة اللغة العربية بكليات التربية في ضوء الاعه نظرية

التلقي؟

r - ما أسس بناء برنامج قائم على نظرية التلقي لتنمية كفايات النقد الأدبي لاى طلاب شعبة اللغة

$$
\text { العربية بكليات التربية ؟ باء برنيج }
$$

r- ما البرنامج القائم على نظرية التلقي لتتمية كفايات النقد الأدبي لاى طلاب شعبة اللغة العربية

$$
\text { بكليات التربية؟ }
$$

ع- ما فاعلية البرنامج القائم على نظرية التلقي في تتمية كفايات النقد الأدبي لدى طلاب شعبة اللغة

$$
\begin{aligned}
& \text { العربية بكليات التربية؟ } \\
& \text { حدود الاراسة : }
\end{aligned}
$$

تقتصر الدراسة الحالية على:

ـ الكفايات النوعية المشتقة من الدفاهيم النقدية المرتبطة بنظرية التلقي؛ حيث تركز برامج إعداد معلمي اللغة العربية بكليات التربية على مناهج ونظريات النقد الكلاسيكي؛ مما أفقد الطلاب ثقافة نقدية حديثة تمكنهم من التفاعل المنتج مع الأدب.

ـ طلاب الفرقة الر ابعة؛ حيث بمتلكون معرفة لغوية وأدبية كافية لِّنُوَّن لديهم أفق من التوقعات

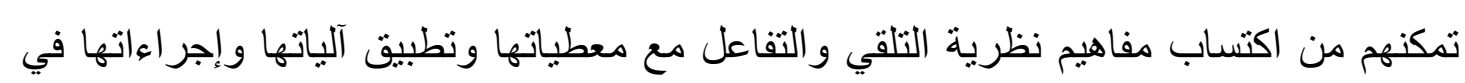
أثناء تواصلهم الأدبي مع النصوص المنضمنة في محتوى البرنامج المقتر ح.

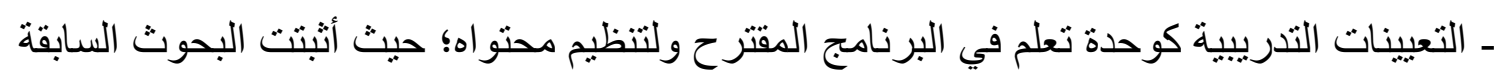

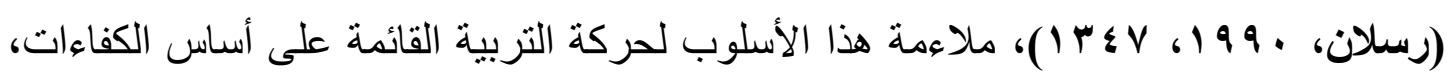


وكذا مناسبته لقدرات واستعدادات طالب الجامعة التي تؤهله للتعلم ذاتياً وبلوغ مستوى الإتقان المر غوب فيه بكفاءة عالية. تحديد المصطلحات:

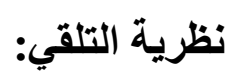

تعددت تعريفات نظرية التلقي ، حيث عرفت بأنها: "مجموعة من المبادئ و الأسس النظرية،

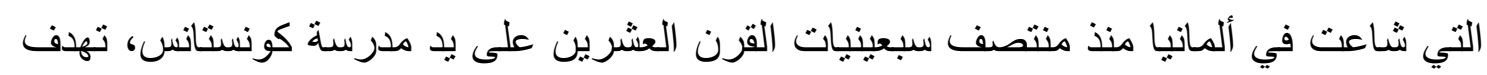

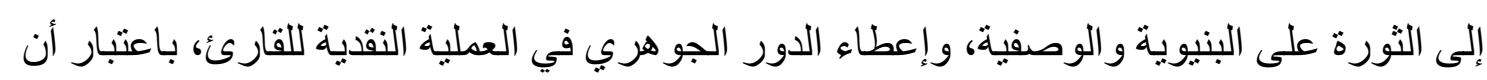

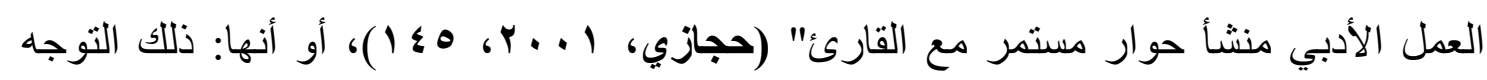

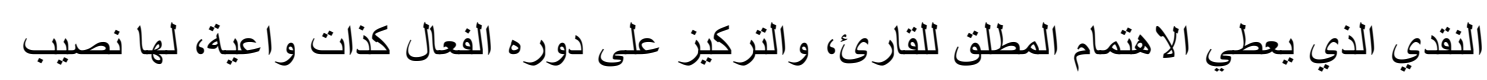

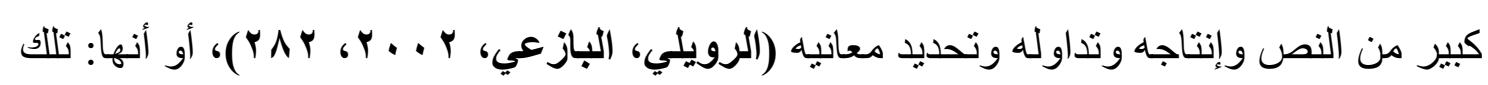

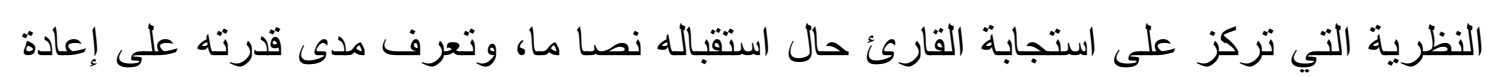

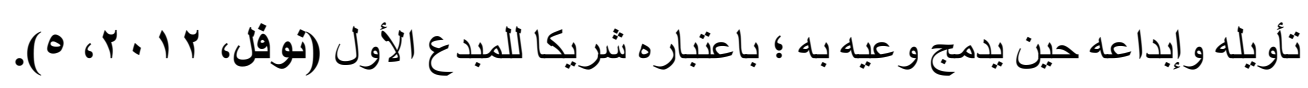
ويقصد بالتلقي في هذه الدراسة : مجمو عة من الإجراءات النقدية المشتقة من نظرية التلقي

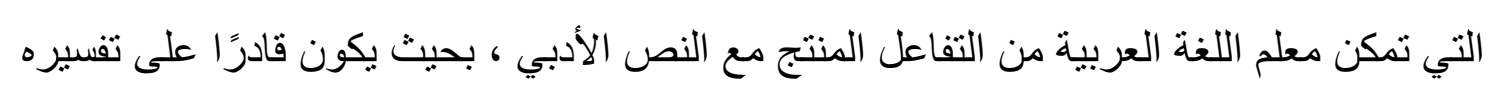
و تحليله ونقده وتذوقه و إعادة تأو يله و منحه معاني متجدئ.

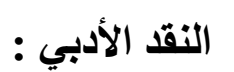
هو محاولة منضبطة يشترك فيها ذوق الناقد وفكره للكثف عن مواطن الجمال أو القبح في الأعمال الأدبية ( طبانة ، 1975 ، 12 ) .

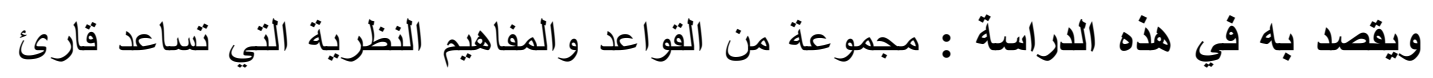
النصوص الأدبية على فهم عمليات التذوق و الاستجابة و الوعي بأدو ات إنتاجها وشروط لهاهي لتقيها. الكفاية : وتعرف بأنها : " القدرة التي تتضمن مجموعة من المهارات والمعارف والمفاهيم

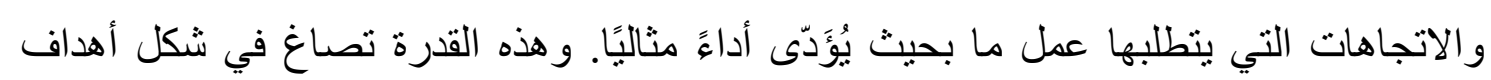

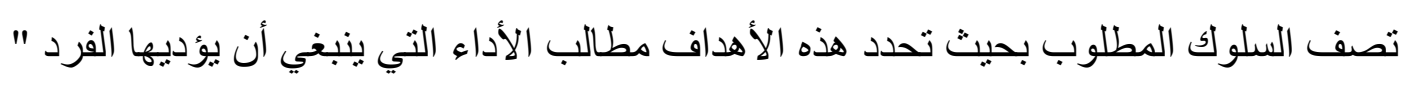
( الناقة ، 1997 ( 12 ، 12 ). 
ويقصد بها في هذه الدراسة : مجموعة المعارف و المفاهيم والمهارات المرتبطة بالنقد الأدبي و المشتقة من نظرية التلقي اللازمة لطلاب شعبة اللغة العربية بكليات التربية ، ويكتسبونها نتيجة مرورهم ببرنامج تدريبي معين ؛ بحيث ترنقي بأدائهم إلى مستوى معين من الإتقان ، ويمكن

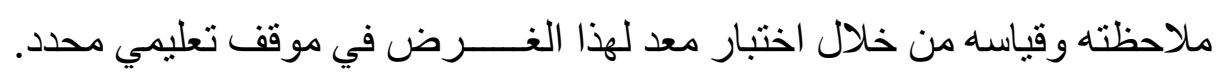

ويقصد بها في الدراسة الحالية:ارتفاع مستوى أفراد عينة الدراسة في إتقان كفايات النقد الأدبي في ضوء نظرية التلقي، ويتحدد ذللك من خلال التحسن و التقام الملحوظ في أداء كل كفاية

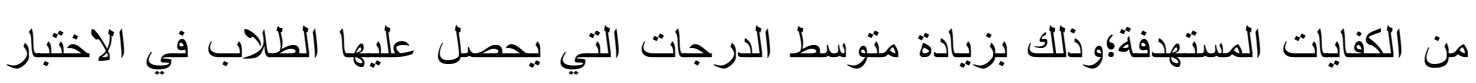

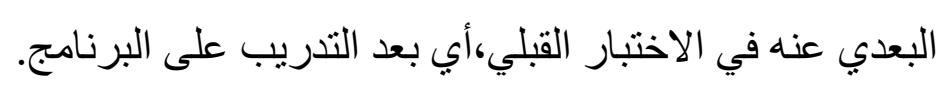

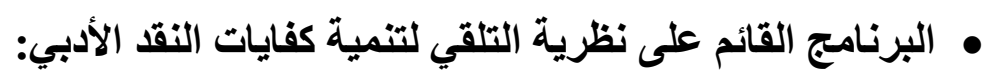
ويقصد به في الاراسة الحالية: تنظيم منطقي للخبرات التعليمية المشتقة من مفاهيم

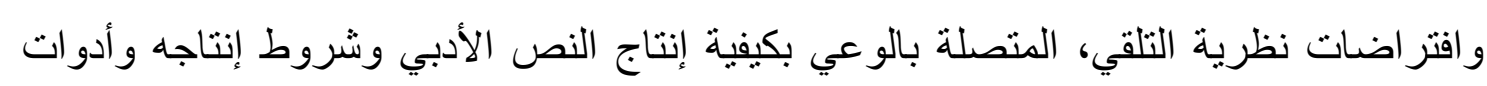

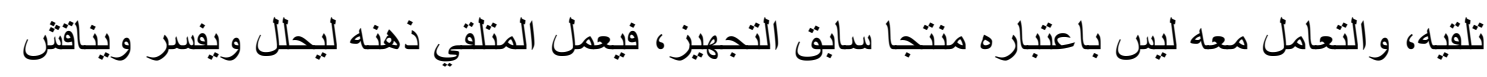

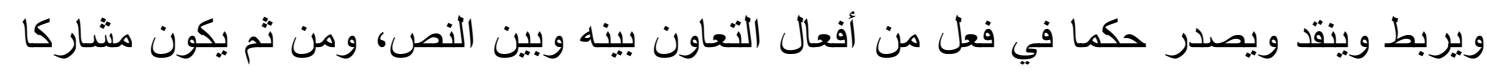

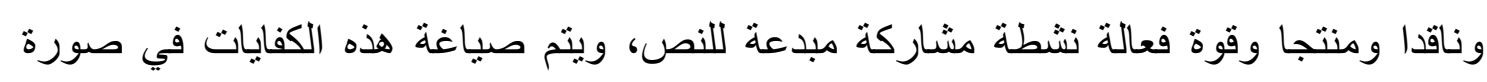

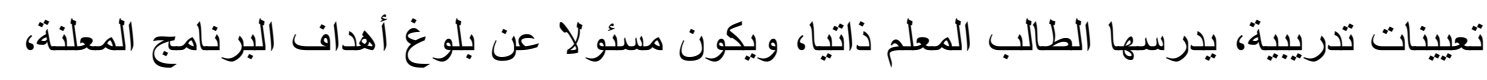

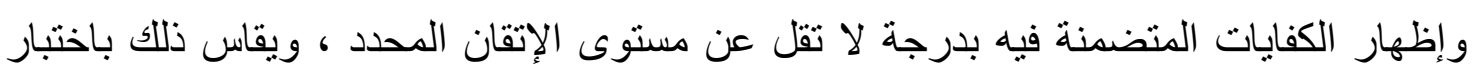

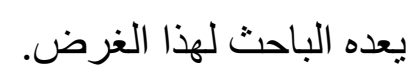

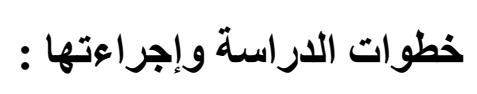

تسير الدراسة وفقاً لمجمو عة من الخطوات واتواتهاء الإجر اءات، تتمثل في: أولاً: تحديد قائمة بكفايات النقل الأدبي اللازمة لطلاب شعبة اللغة العربية بكليات التربية في ضوك

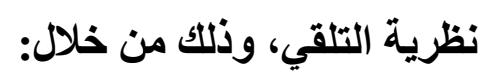
ـ در اسة البحوث السابقة والأدبيات التي تتاولت نظرية التلقي في الأدب العربي ونقده. ـ در اسة طبيعة النقد الأدبي. ـ در اسة طبيعة الطلاب المعلمين بكليات التربية. ـ آراء الخبر اء و المختصين في النقد الأدبي ، ومناهج وطر الطئق تدريس اللغة العربية. 
ثانيًا : تحديد أسس بناء برنامج قائم على نظرية التلقي لتنمية كفايات النقل الأدبي لدى طلاب

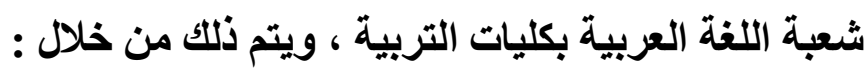
ـ در اسة ما تم التوصل إليه في الخطوة السابقة. ـ در اسة البحوث السابقة و الأدبيات التي تناولت نظرية التلقي. ـ آراء الخبر اءو المتخصصين. ثالثًا : بناء البرنامج القائم على نظرية التلقي لتتمية كفايات النقل الأدبي لاى طلاب شعبة اللفة

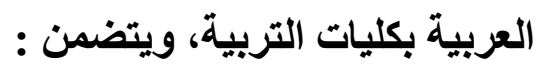

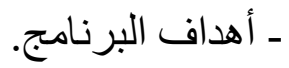

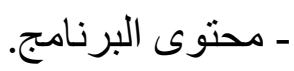
ـ ـ طر ائق و استر اتيجيات التنريس المنضمنة في البرنامج. ـ الأنشطة و الوسائل التعليمية المستخدمة في البرنامج. - إجراءات التقويم في البرنامج. رابعًا : تحديد مدى فاعلية البرنامج القائم على نظرية التلقي في تنمية كفايات النقل الأدبي لاى طلاب شعبة اللغة العربية بكليات التربية، وذلك من خلال: - بناء اختبار الكفايات النقدية في ضوء نظرية التلقي وضبطه. ـ اختيار عينة من طلاب الفرقة الرابعة عام تخصص اللغة العربية بكلية التربية جامعة بنها، وتطبيق الاختبار عليها تطبيقا قبليا. ـ ـ تدريس البرنامج لعينة الدراسة. ـ تطبيق اختبار المفاهيم النقدية في ضوء نظرية التلقي تطبيقا بعديا على عينة الدراسة. - رصد البيانات ومعالجتها إحصائيا ومناقثتها وتفسير ها. ـ تقديم التوصيات و المقترحات.

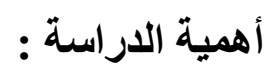
تستمد هذه الدر اسة أهميتها مما يمكن أن تسهم به في:

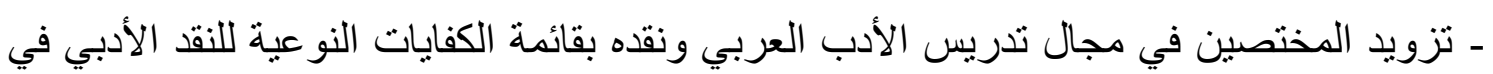
ضوء نظرية التلقي. 
ـ تزويد المختصبن في مجال تدريس الأدب العربي ونقده باختبار المفاهيم النقدية في ضوء نظرية

التلقي.

ـ تزويد المختصين في مجال تدريس الأدب العربي ونقده ببرنامج لتنمية كفايات النقد الأدبي في ضوء نظرية التلقي لاى طلاب شعبة اللغة العربية بالمرحلة الجامعية. ـ تتمية كفايات النقا الأدبي في ضوء نظرية التلقي اللازمة لطلاب شعبة اللغة العربية بكليات التربية، مما يمكنهم من التوصل الأدبي مع النصوص الثعرية والنترية القائم على التفاعل

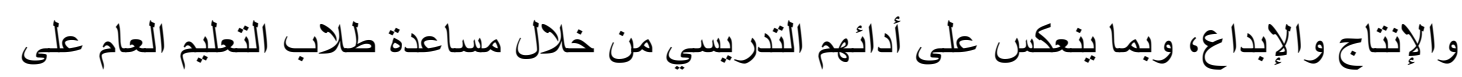
التحليل و النقد وتذوق النصوص الأدبية المقدمة لهم. ـ فتح المجال لاراسات علمية مستقبلية في مجال كفايات النقد الأدبي في ضوء لنوف نظرية التلقي اللازمة لمعلم اللغة العربية.

وفيما يلي عرض تفصيلي لإجراءات الدراسة ؛ وذلك من خلال تتاول المحاور التالية : " المحور الأول : المفاهيم المركزية لاى رواد نظرية التلقي ، وكفاياتها النقدية :

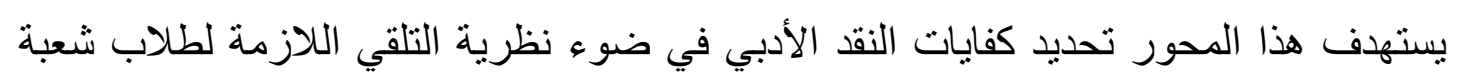

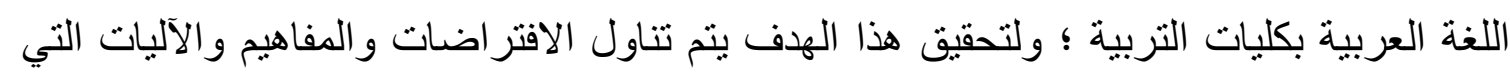

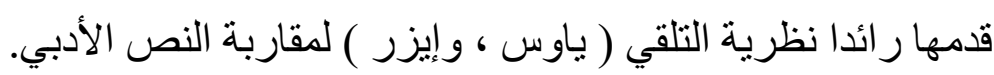

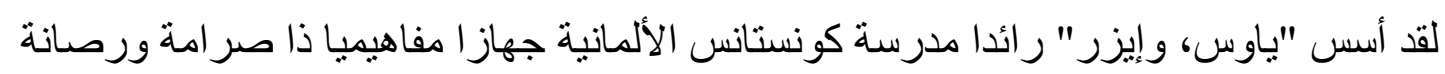

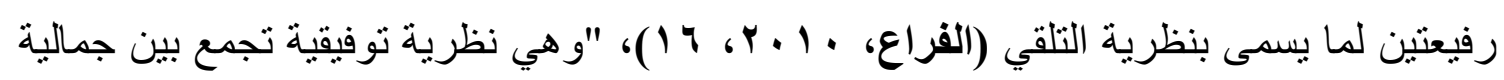

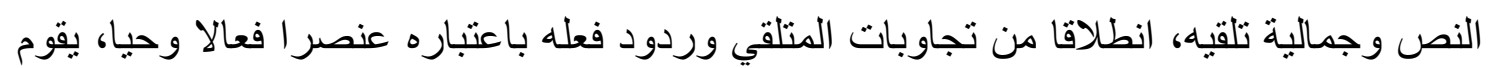

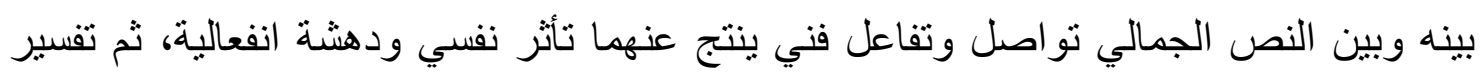
وتأويل، فحكم جمالي استنادًا إلى موضوع جمالي ذي علاقة بالوعي الجمعي، مما يعني أن القيمة

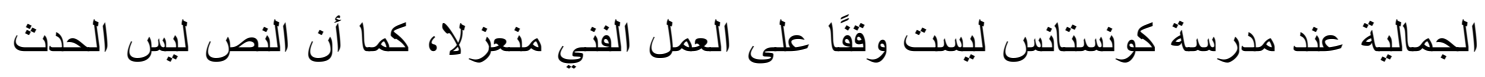
الوحيد الذي يجسد هذه القيمة، فهناك أيضا تفاعل المتلقي وردود فعله إزاء النصا، حئ حين يتأمله

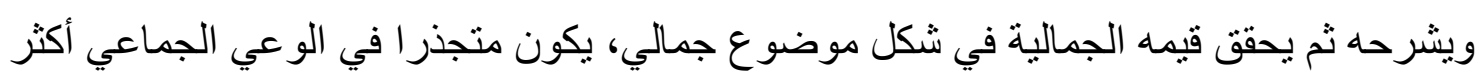

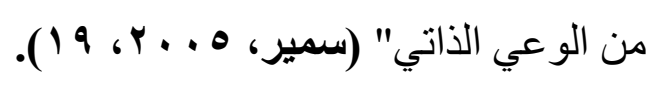

و إذا كان "ياوس، وإيزر" يجمعهما أساس نظري مركزي، ويشتركان في مفاهيم كثيرة

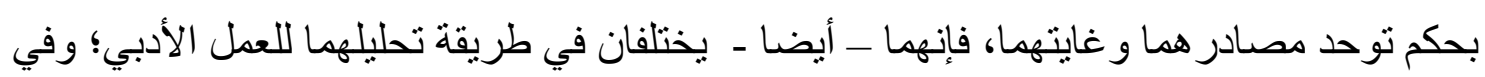


الفرضيات التي انطلق منها كل واحد، وفيما يلي عرض لتصور هذين المنظرين لتلقي العمل الأدبي من خلال الفرضيات و المفاهيم التي تبناها كل منهما.

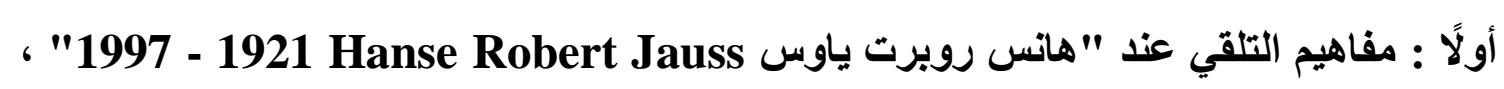
وكفاياتها النقدية: يعد "ياوس" المنظر الأول الذي طور التلقي الأدبي، وقد انطلق في نظريته عن التلقي، من

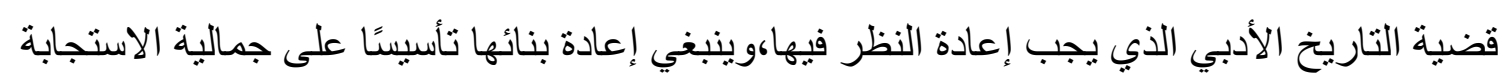

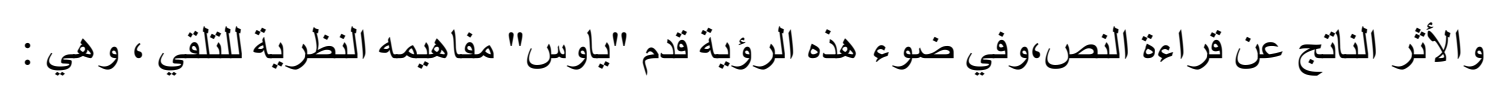

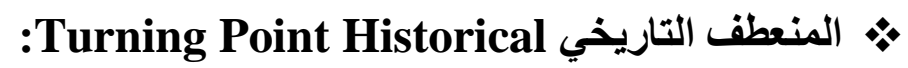

تعد "نظرية التلقي Reception theory" حسب وجهة نظر رائدها الأول "هانس روبرت

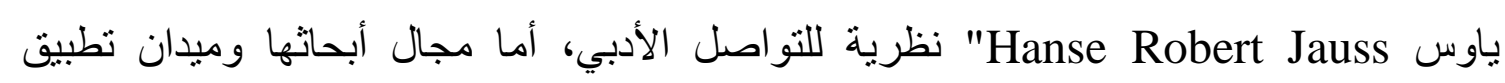

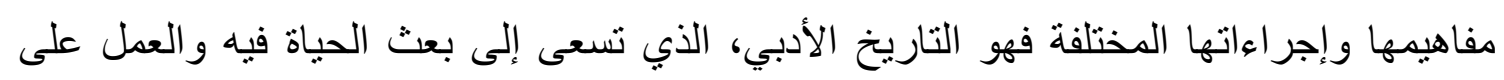

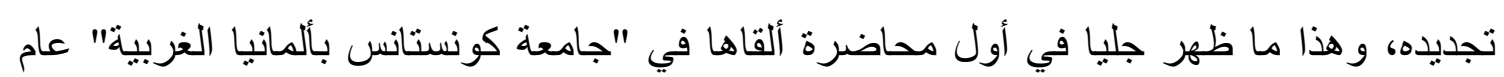

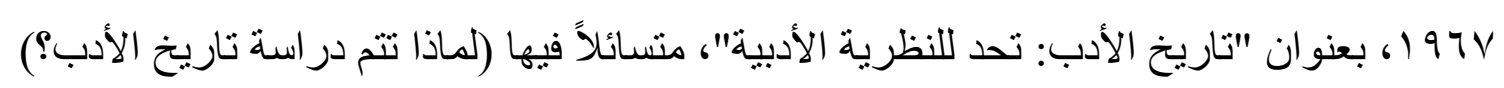

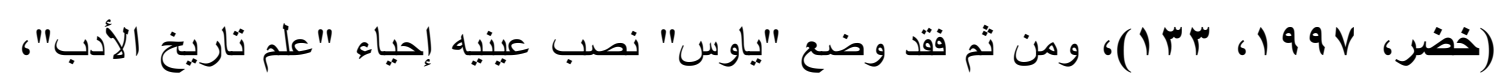

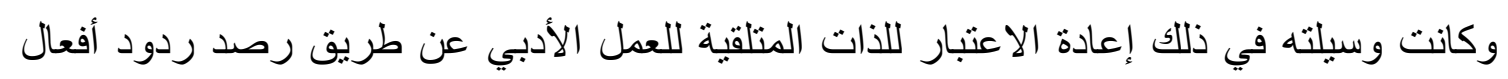

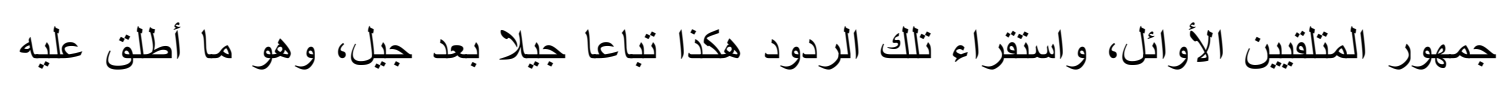

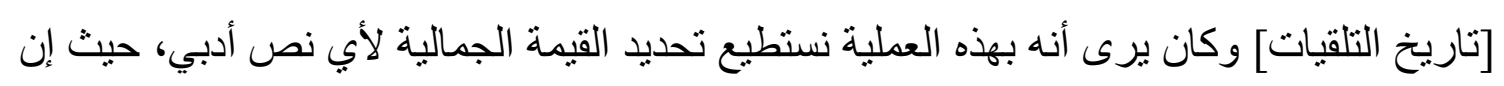

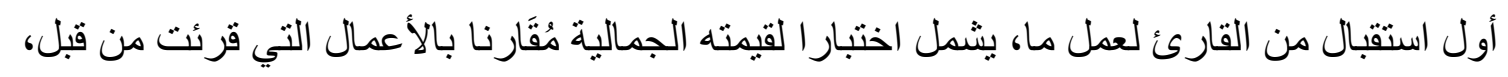
و الدلالة التاريخية الواضحة لهذا هي أن فهم القارئ الأول سيؤخذ بها، وسينمى في سلسلة من لفئل

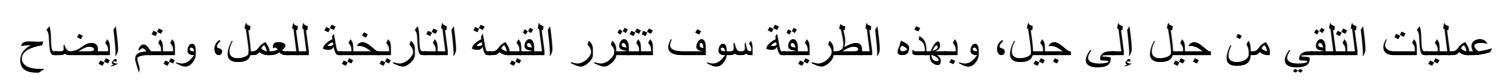

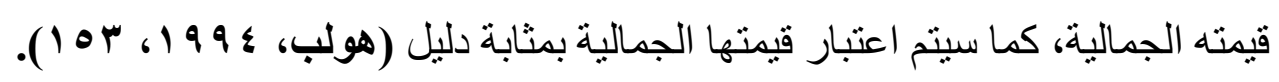

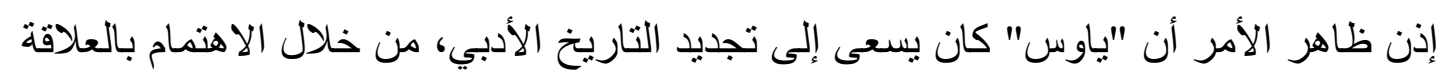

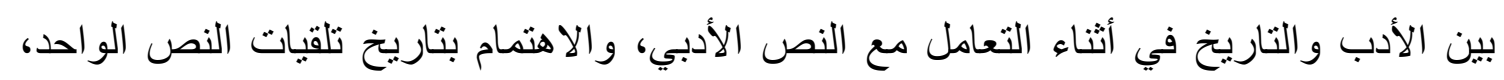

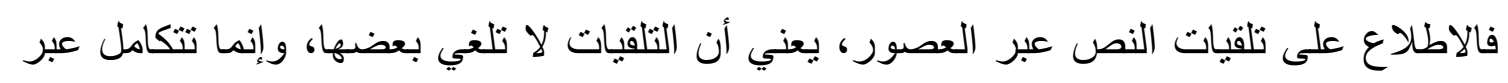
العصور و الأزمنة. 
ولهذا يدعو "ياوس" إلى أن يكون التاريخ تسجيلا لمختلف تلقيات الأثر الواحد عبر الزمن،

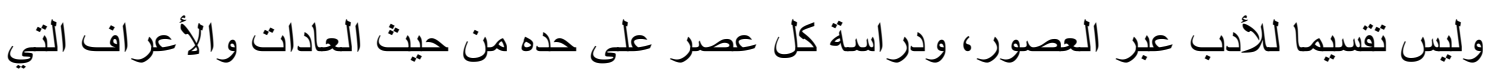
عرفتها بيئة الأديب عند إنتاج النص. من هذا المنطلق، إذن، نظر" ياوس" إلى تاريخ الأدب باعتباره سلسلة من التلقيات

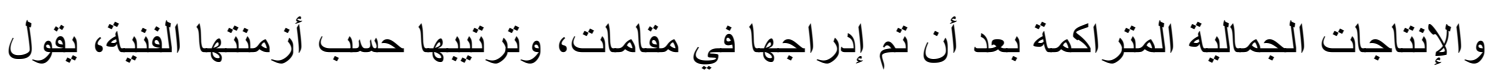
"ياوس": "إن العلاقة بين العمل الأدبي والقارئ تعرض من خلال وجهين اثنين: وجه جمالي،

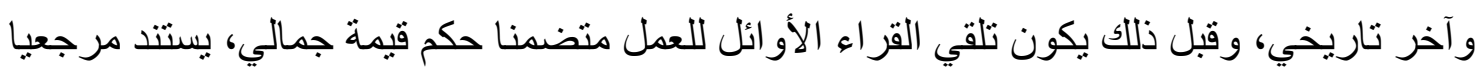
إلى أعمال أخرى قرئت من قبل. إن هذا الفهم الأول للعمل يسنطيع من بعد أن يتطور ويغتني من

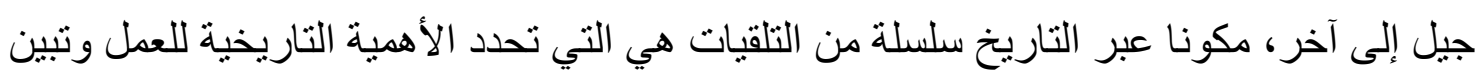

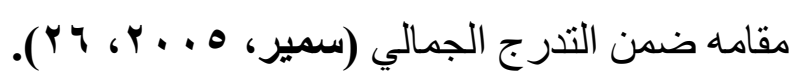
إن "ياوس" حين يدمج جمالية الأدب ضمن منظومته التاريخية، إنما يؤكد تو اصلية الأدب

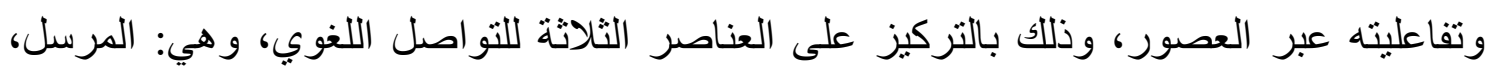

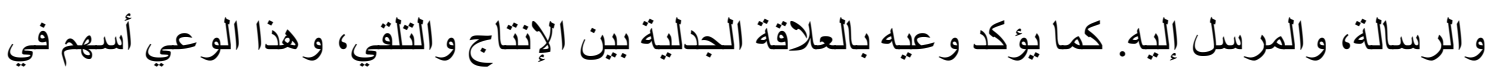

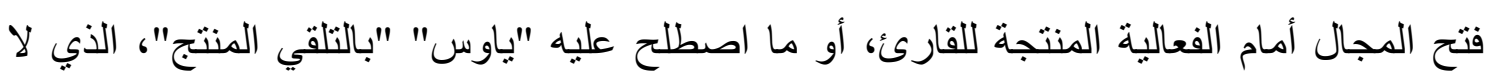
يكون المتلقي في إطاره مستقبلا سلبيا للعمل الأدبي، بل يصبح لبنة رئيسة في عملية استكمال دائرة

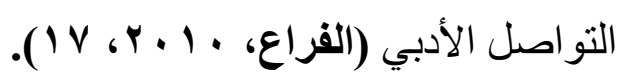
وفي ضوء مفهوم المنعطف التاريخي يمكن اشتقاق بعض الكفايات النقدية المتعلقة بهذا ـ ـ يقارن بين المعرفة التاريخية و المعرفة الجمالية للعمل الأدبي.

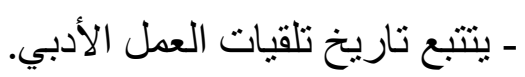
- يو ازن بين القراءات المتعددة للعمل الأدبي.

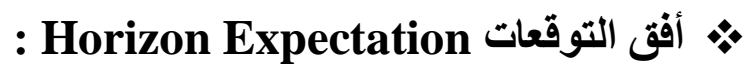

في سبيل سعي "ياوس" لتأكيد العلاقة بين المعرفة التاريخية و المعرقة الجمالية، ودورها في تلقي العمل الأدبي، جاء مفهومه الأساسي "أفق التوقعات" الذي يعد الدحور والركيزة الأساسية

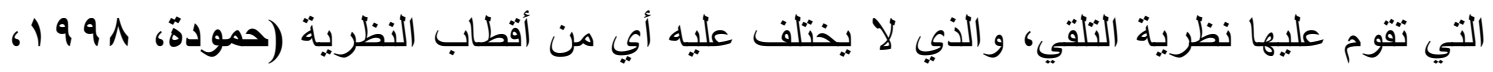

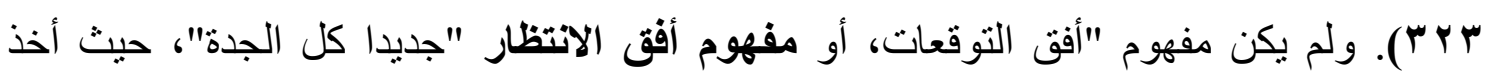


"ياوس" مفهوم "الأفق" من "جادامير GADAMMER" رائد النظرية "الهرمنيوطيقية أو التفسيرية أو التأويلية" مركبا معه كلمة "الانتظار"، كما أخذها من مفهوم "خيبة الاتتظار" عند "كارل بوبر KARL.R.POPPER" رائد المنهج التاريخي (محمد، 999 19، 9 . 1 )، وقد وجد

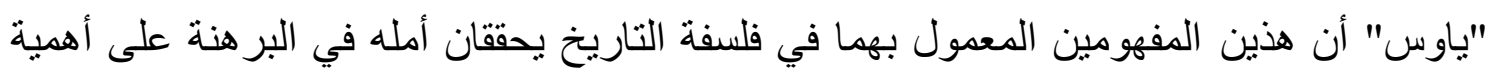
التلقي في فهم الأدب و التأريخ له، ويعني مفهوم "الأفقى" عند "جادامير": أنه لا يمكن فهم أية حقيقة

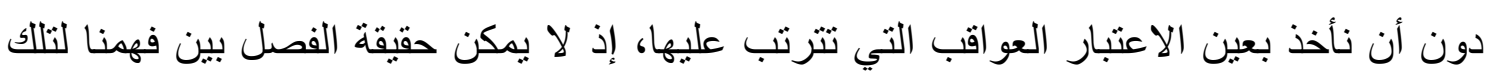

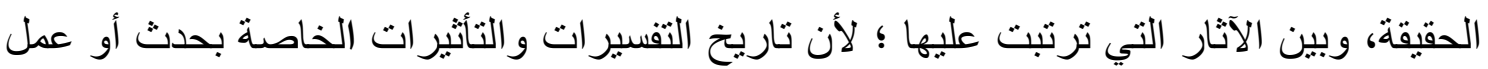

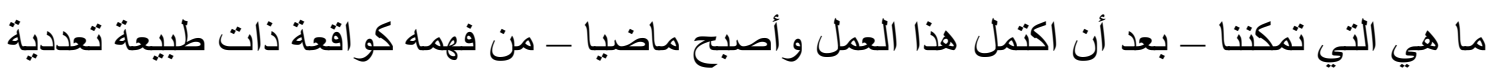

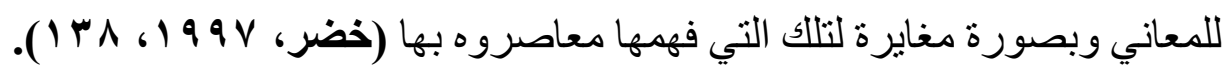

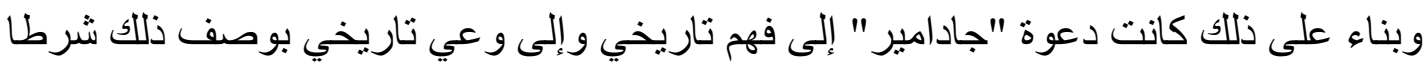

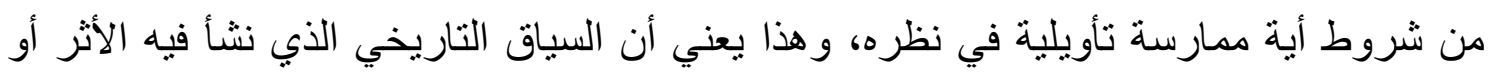

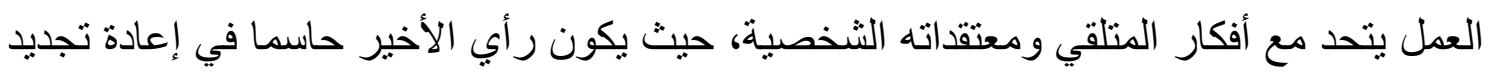
معنى النص، ويسمي "جادامير" ذلك بأنه "انصهار آفاق" أي: أفق النص و أفق المؤول أو المتلقي التئي

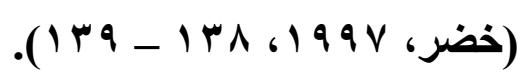

إن المفهوم العام لأفق التوقع يتجّلى في التهيؤ القبلي (المسبق) للقارئ أو ما يجيء به من الته

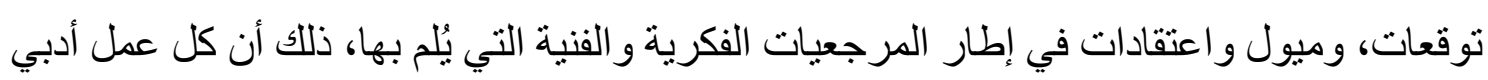

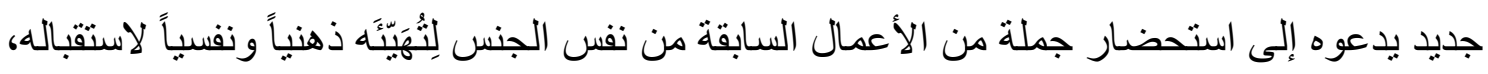
مما يأخذ به إلى خلق توقعات معينة، وقد ذهب "ياوس" في ذلك إلك إلى أن الأثر الأدبي يتجه إلى دلى

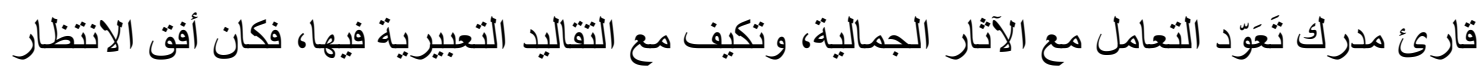

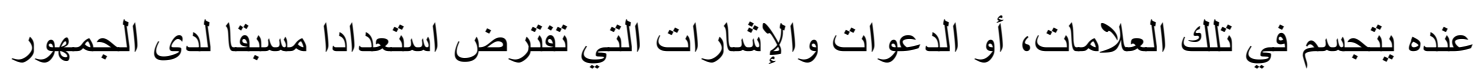

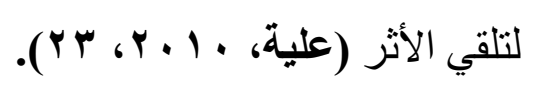

كما يشير مفهوم أفق التوقعات إلى مجموعة الخبرات والكفايات التي يختزنها المتلقي

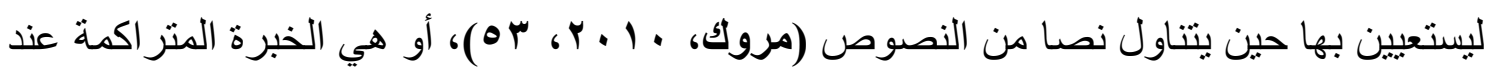

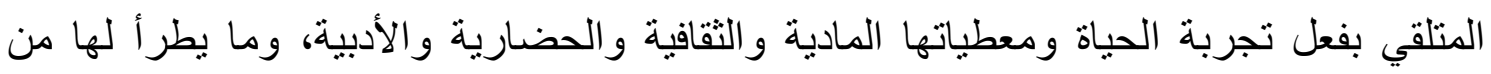

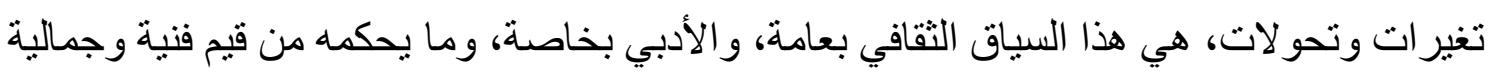

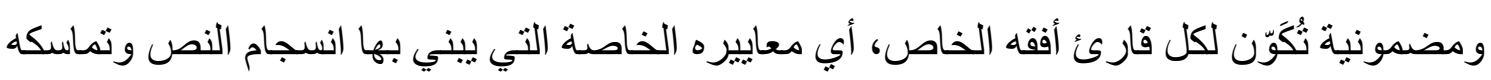


دلالياً، أي يؤوله. وتبدو هذه الخبرة المثر اكمة بعد أن تتبلور، وتتفاعل عناصر ها (القعود، ؟ . . ؟ ، דיז

ويتثكل أفق التوقعات حسب "ياوس" من ثلاث عناصر أساسية، هي (ياوس، ؛ . . ץ، 0 ؛ ـ

• المعرفة القبلية التي يكتسبها القارئ عن الجنس الأدبي الذي ينتمي إليه العمل الأدبي الذي

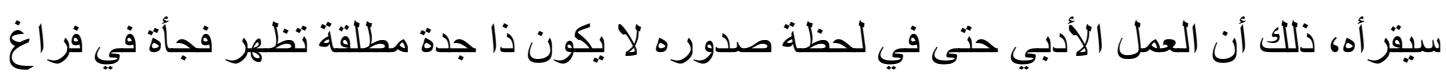
.... فكل عمل يذكر القارئ بأعمال أخرى سبق له اله أن قرأها.

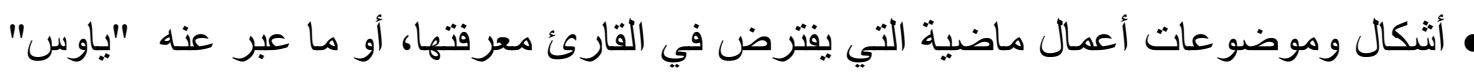

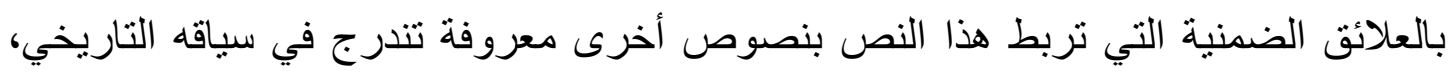
حيث إن النص الجديد بستدعي بالنسبة للقارئ أو السامع مجموعة كاملة من التوقعات

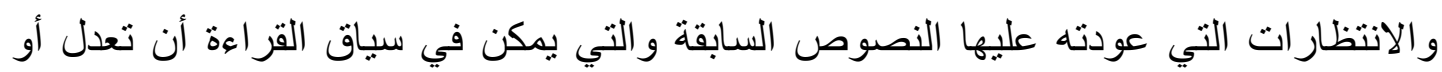

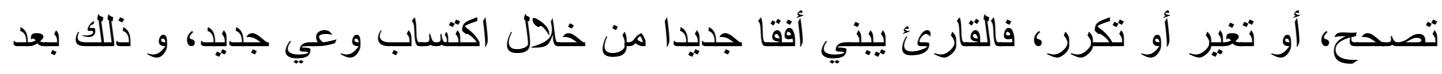

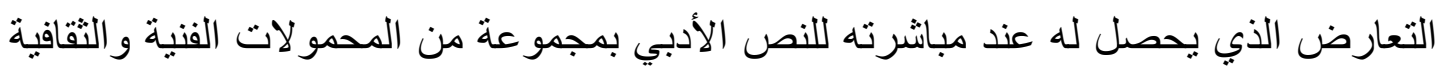
وبين عدم استجابة النص لتلك الانتظار ات و التوقعات. • التعارض بين اللغة الثعرية (العالم الخيالي) و اللغة العملية (العالم اليومي)، أي بين الوظيفة

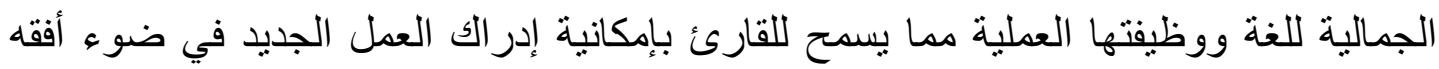

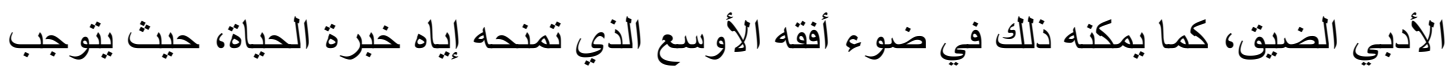

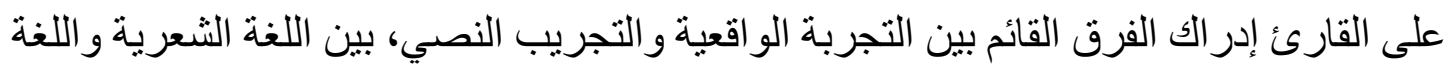
العملية، فثمة تعارض بين العالم التخيلي والواقع اليومي، وعلى هذا تتم عملية بناء المعنى

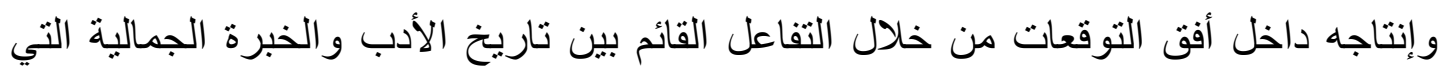
يكتسبها القارئ.

إذن يمكن القول بأن مفهوم أفق التوقعات ينكون من ثلاثة عناصر رئيسة، بعضها يتصل

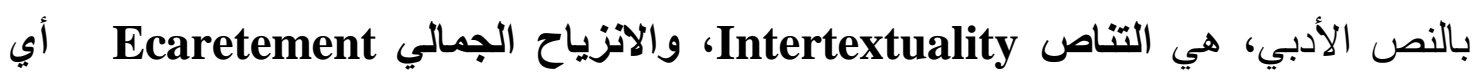
انحراف Deviation اللغة الثعرية عن التعبير اللغوي المألوف، وبعضها الآخر يتصل بالمتلقي، تتمثل في خبرته الفنية والأدبية السابقة. 
وفي ضوع مفهوم أفق التوقعات يمكن اشتقاق بعض الكفايات النقدية المتعلقة بهذا المفهوم :

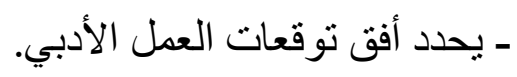
- يحدد أفق انتظاره للعمل الأدبي.

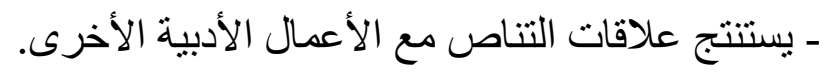
- يحكم على النص الأدبي في ضوء انزياحاته الجمالية.

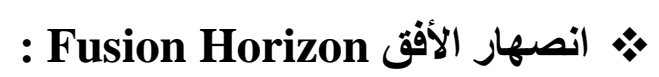

يعد مفهوم أفق التوقعات شرطاً معياريا أو معيارا شرطيا لتلقي النص الأدبي وتأويله

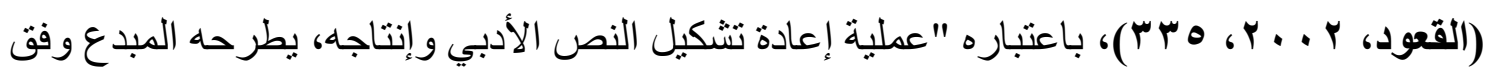

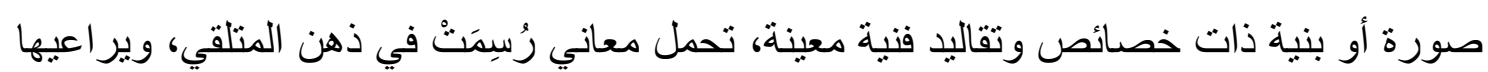

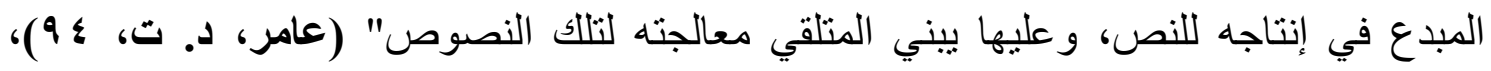
فالمتلقي (القارئ) الجاهلي مثلا ينتظر من شاعره قصيدة ذات تقاليد فنية تتسق وبنية النص الجاهلي

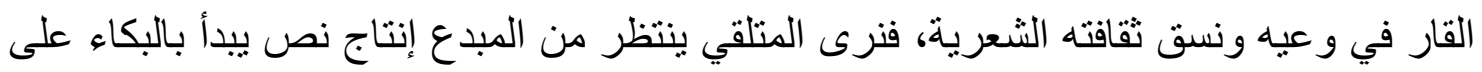

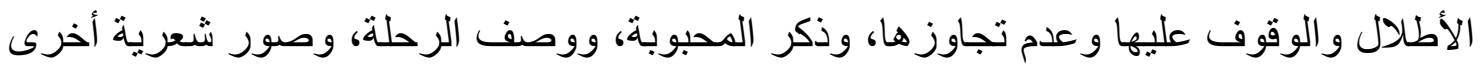
ذات تقاليد فنية استقرت في وعيه الثعري وذهنه مسبقًا. و هذا يعني أنه عندما يتوافق أفق المتلقي مع أفق النص؛ فئن فئن ذللك يسمى بانصهار أو اندماج

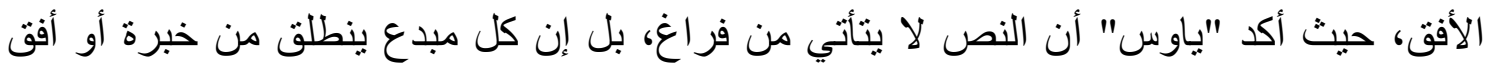

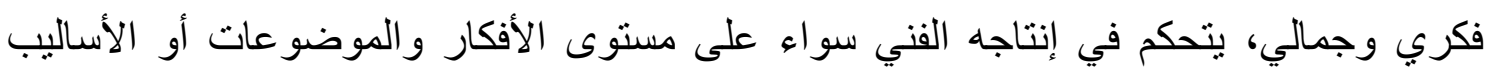

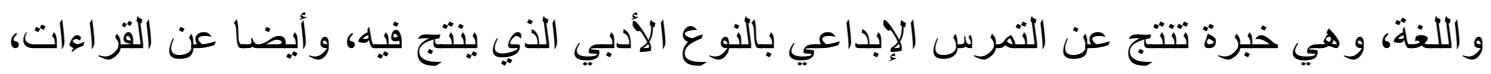

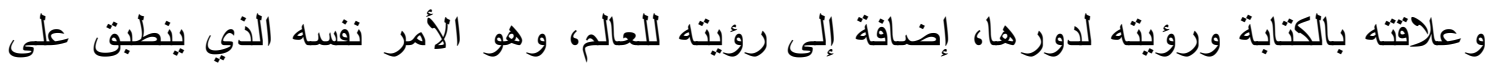

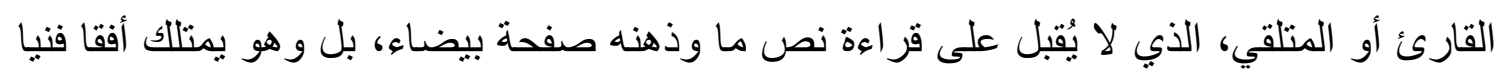

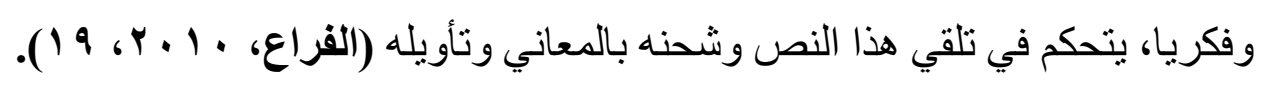

وفي ضوء مفهوم انصهار الأفق يمكن اشتقاق بعض الكفايات النقاية المتعلقة بهذا المفهوم :

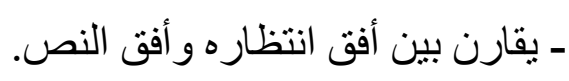

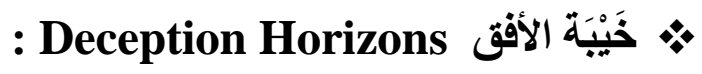

عندما يتلقى القارئ نصا أدبيا ما لا يتو افق في سماته و أسلوبه وشكله ولغته وموضو عاته مع المعايير المألوفة لديه؛ فإنه يصطدم بلحظة الخيبة، حيث يخيب ظن المتلقي في مطابقة معاييره 
السابقة مع المعايير التي ينطوي عليها العمل الجديد (محمد، 999 (1)، 1 (1))، ومن ثم تحدث له ما بسمى بالمفاجأة Surprisingness، والتي تعني الأثر الذي يحدث في وعي المتلقي نتيجة

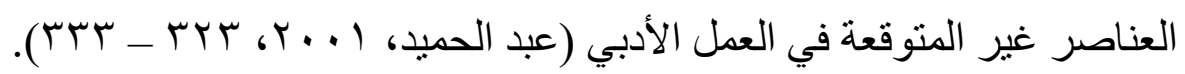

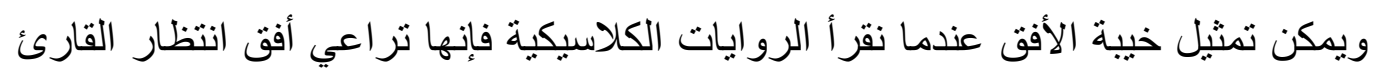

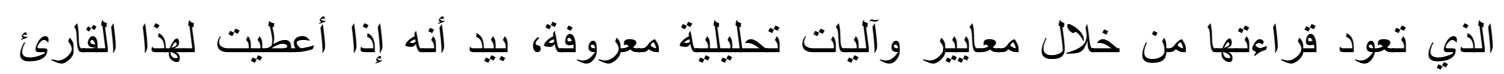
الكلاسيكي رواية حداثية فإنه يخيب توقعه. ومن ثم، فإن لحظات الخيبة مهمة جدا بالنسبة للمتلقي؛ حيث يحدث فيها تأسيس الأفق

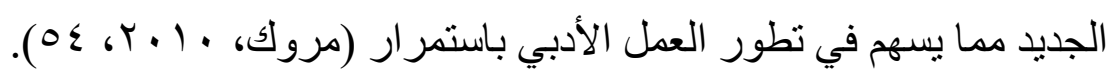
وفي ضوء مفهوم خيبة الأفق يمكن اشتقاق بعض الكفايات النقدية المتعلقة بهذا المفهوم :

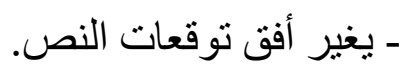

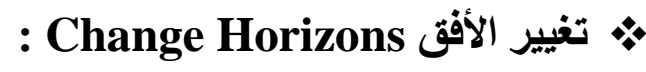

بعد أن قرأ المتلقي النص الأدبي وخيب أفق انتظاره: إما أن لا ينسجم مع النمط الجديد

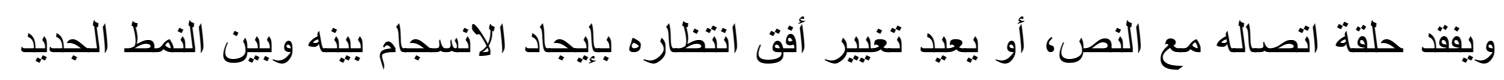

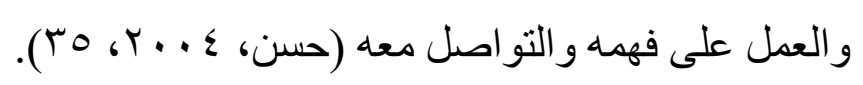

إن كل أدب حق ير اهن على تغيير وتعديل آفاق توقعات قر ائه، وعليه يتضح تطور العلاقة

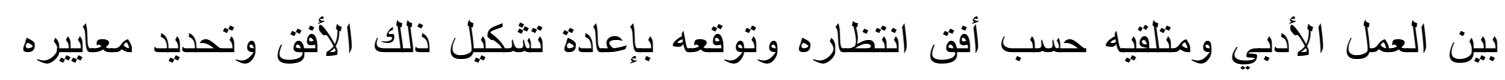

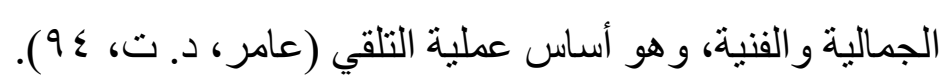
وفي ضوء مفهوم تغيير الأفق يمكن اشتقاق بعض الكفايات النقدية المتعلقة بهذا المفهوم : - يقيس تغيير الأفق.

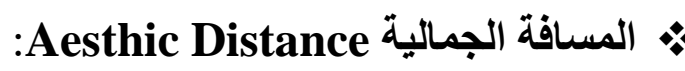

تسمح عملية إعادة تشكيل أفق توقع عمل أدبي ما، من منظور "ياوس" بتحديد قيمته الفنية؛

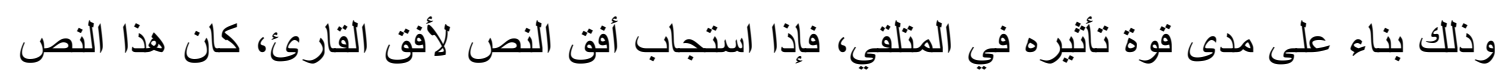

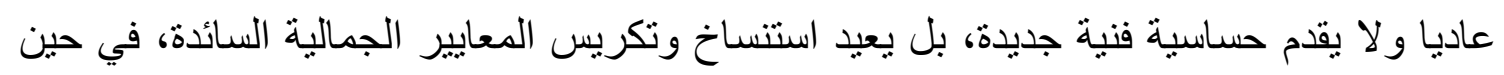

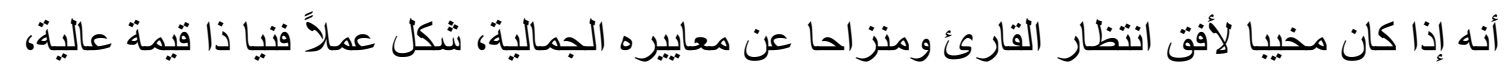
ويسمي "ياوس" الفرق بين أفق الكتابة وأفق القراءة بـ"الهسافة الجمالية"، و التي بمكن قياسها من 
خلال ردود أفعال القراء وأحكام النقاد، لتشكل وحدة قياس للتوتر بين أفق النص وأفق انتظار

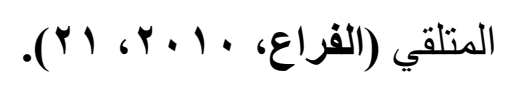

ويسمح مفهوم المسافة الجمالية بأن نميز بين ثلاث حالات من ردود الفعل لاى المتلقيين

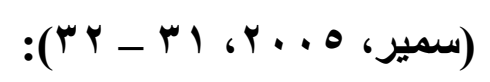

- أن تكون الكتابة وفق معيار جمالي واحد معروف لدى القارئ، يجد فيه تأكيدا لأفق انتظاره. وفي

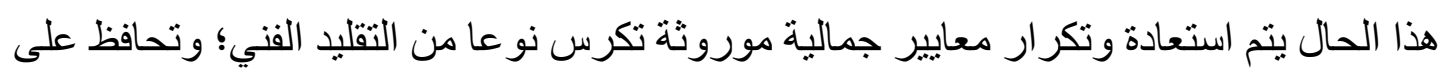
إرثه الجمالي، انطلاقا مما اكتسبه الجنس الأدبي في مساره التاريخي. و هنا نكون إزاء تلقئ أدبي

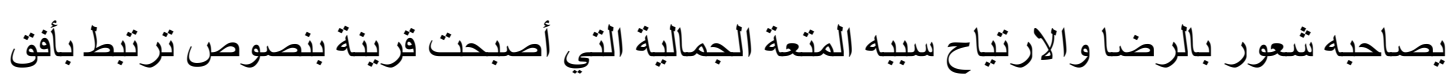
ذي تقاليد جمالية موروثة، تنتج عنها لذة تسمى "لذة النص" The Pleasure Of The

.Text ـ أما الحالة الثانية فقيها يتم التصادم بين عمل أدبي جديد وبين أفق انتظار متداول ومألوف. و هذا ما

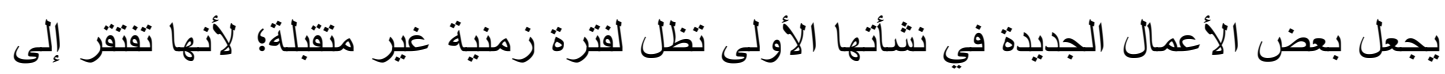

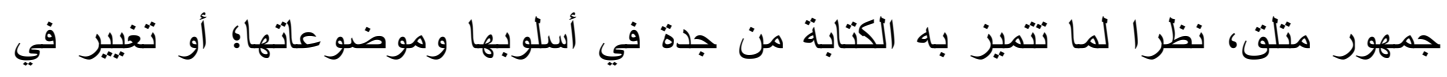

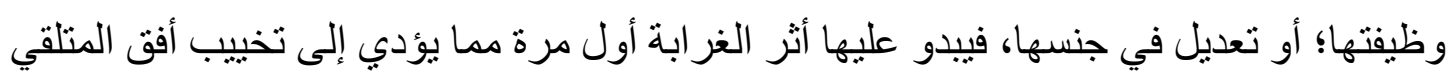

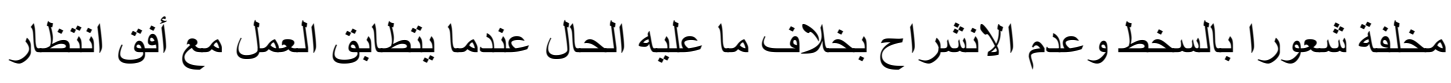

$$
\text { المتلقي. }
$$

- إن الحالة الثانية سر عان ما تؤدي بنا إلى حالة أخرى وذللك عندما تتمكن الدقاييس الجمالية الجديدة

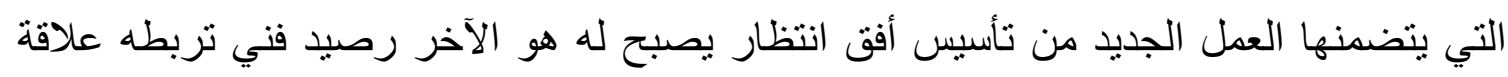

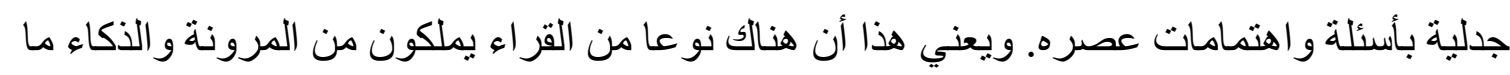

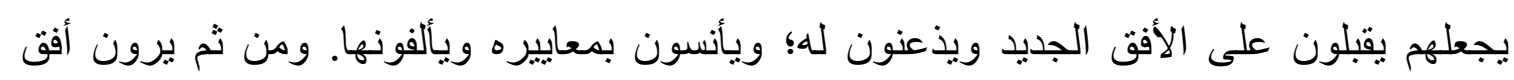

انتظار هم يتغير، وذخيرتهم الفنية تتسع شيئا فثيئًا. وتعد المسافة الجمالية في نظر "ياوس" هي المعيار الذي تقاس به جودة العمل الأدبي وقيمته الفنية،

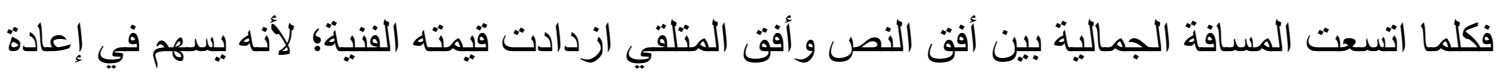
توجيه تجربة القارئ نحو أفق تجربة جمالية جديدة، وإذا لم يتمكن من ذللك، فإنه يكون أقرب إلى إلى إنى مجال "فن الطبخ" وفق تعبير "ياوس"؛ لأنه يستنسخ معايير متداولة بشكل كبير في أفق انتظار

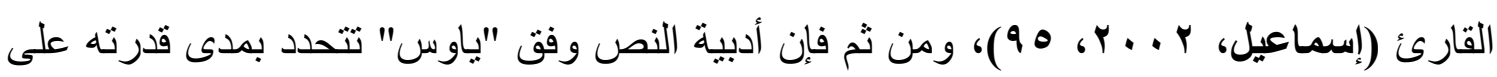


عدم السقوط في الابتذال وخرق المعايير الجمالية السائدة بشكل يؤدي إلى تأسيس معايير فنبة جديدة؛

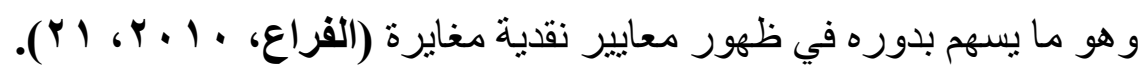

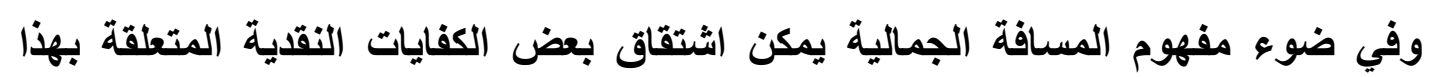

- يحكم على النص في ضوء مسافته الجمالية.

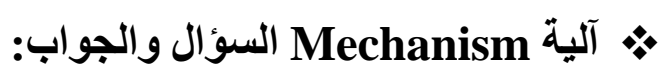

يرى " ياوس" أن تأسيس الأفق وتغييره لتحقيق التفاعل بين العمل الأدبي والمتلقي رهين بآلية

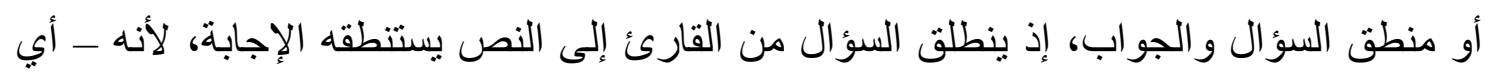

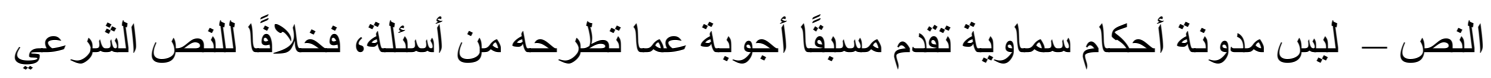
الذي يعتبر حجة والذي يتعين إدراك معناه الجاهز على "كل امرئ يمتلك أذنين للسماع"، فإن النهان

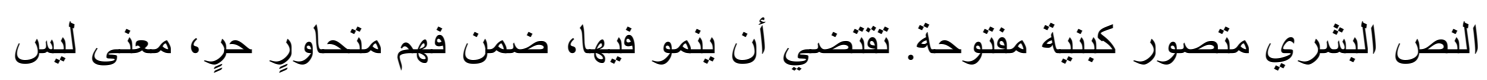

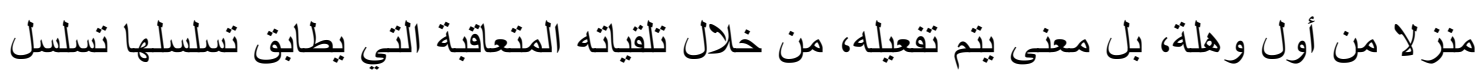

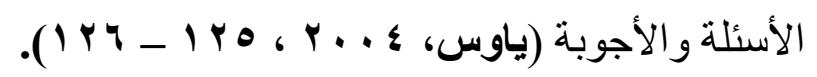

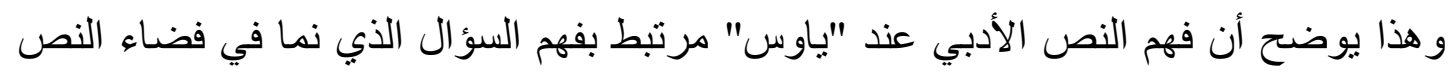
وقدم لله جوابا عنه؛ وهذا ما يقتضي اللجوء إلى منطق السؤال والجواب عند كل على علية فهر النصوص وتأويلها.

ولقد استوحى "ياوس" هذه الأداة التأويلية من "هرمينوطيقا السؤال والجواب لدى

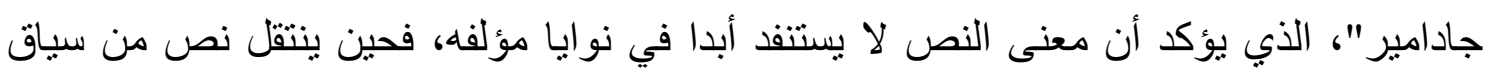

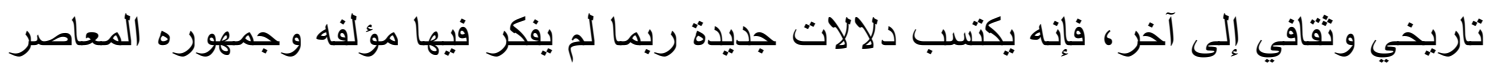

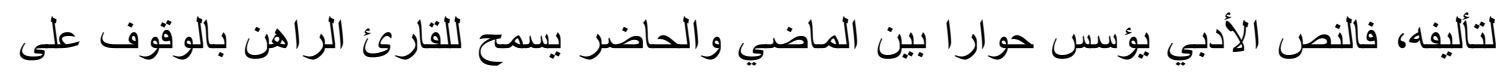

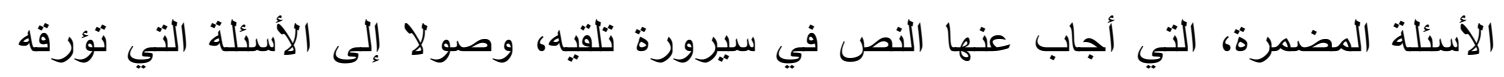

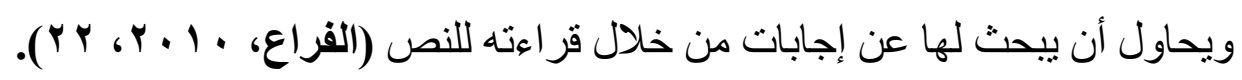

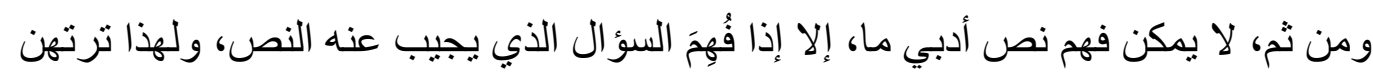

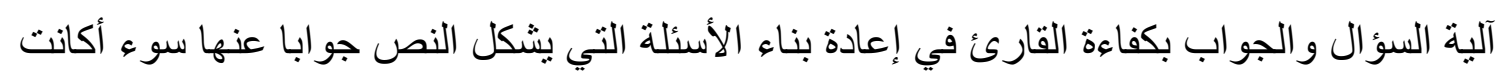
أسئلة جمالية وفنية أم أسئلة أخلاقية أم أسئلة فكرية. 
وفي ضوء آلية السؤال والجواب يمكن اشتقاق بعض الكفايات النقدية المتعلقة بهذا المفهوم : ـ يطبق آلية السؤ ال و الجواب في بناء معاني النص وتأويلها.

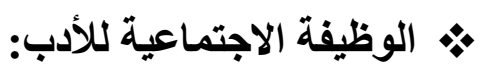

يرى "ياوس" أن النص لا يُتَلَّقى ويحكم على مستوى أدبيته من خلال تضمنه لمعايير

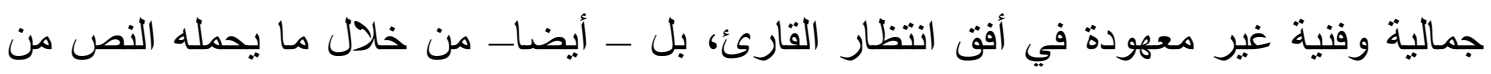

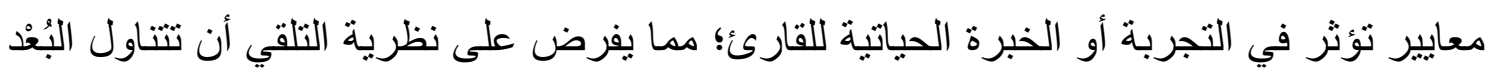

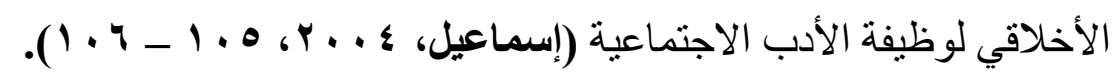
ويوضح "ياوس" أن الوظيفة الاجتماعية للأدب ليست هي التعبير عن المجتمع أو تصويره _ كما كان سائدا للى المناهج النقدية السابقة - بل هي إبداعه للمجتمع من خلال إعطاء المباء المتلقي

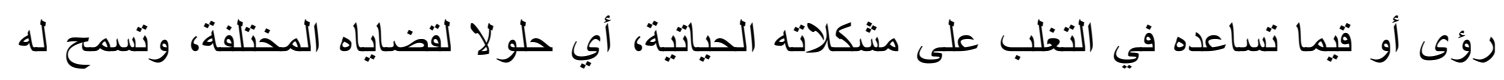

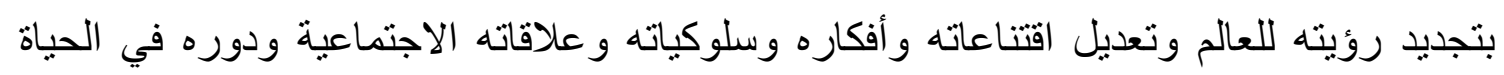

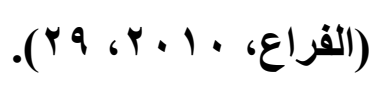

وفي ضوء مفهوم الوظيفة الاجتماعية للأدب يمكن اشتقاق بعض الكفايات النقدية المتعلقة بهذا

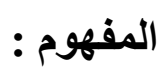

ـ يُعَيَّم النص في ضوم: لئو ما يتضمنه من اتجاهات وقيم اجتماعية و إنسانية.

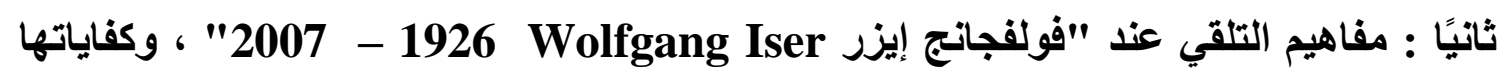
النقدية: يعد "إيزر " الُُنَظِر الثاني لنظرية التلقي، وإذا كان "ياوس" القطب الأول للنظرية مهتما

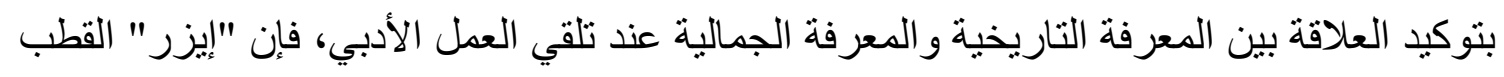

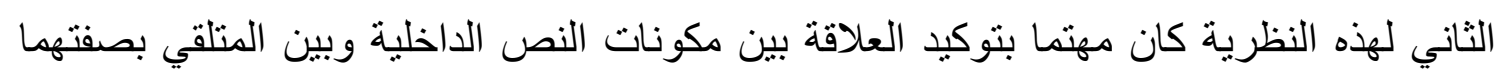

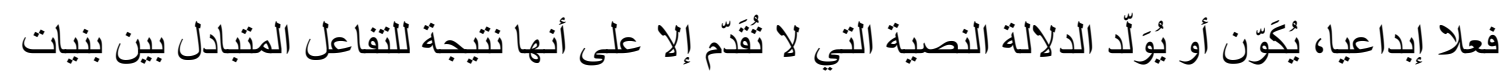

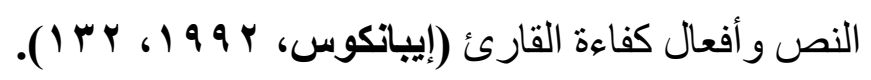
و هذا يعني أن "إيزر" كان اهتمامه منصبا بأبعاد القراءة وآليات الفهم عند المنلقي القارئ للنص النص

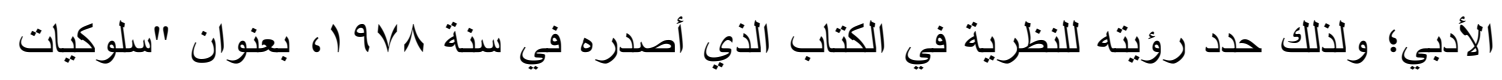

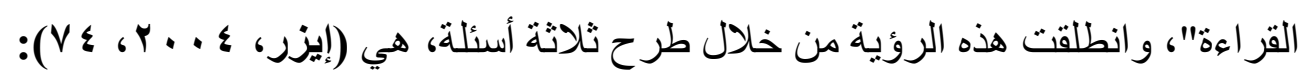
ـ كيف ينمّ استيعاب النصوص وفهمها؟ 
ـ ما البنيات النصيّة التي توجّه القارئ في أثناء عمليّة القر اءة؟ ـ كيف يكون للنص معنى بالنسبة للقارئ وفي ضوء هذه الإجابة عن هذه الأسئلة بنى "إيزر" مفاهيمه الأساسية التي توجه القارئ وتحدد دوره في تلقي العمل الأدبي، ويمكن تحديدها في الآتي:

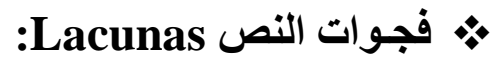
يقدم "إيزر" هذا المفهوم ليؤكد دور المتلقي في عملية التواصل الأدبي، فالعمل الإباعي من وجهة نظره له قطبان: قطب فني Artistic Pole، وقطب جمالي Aesthetic Pole، فالقطب الفني يكمن في النص الذي يؤلفه الكاتب، أما القطب الجمالي فيكمن في الإدر الك الذي ينجزه القارئ لسبر أغوار النص واستكناه دلالاته والبحث عن معانيه الخفية والواضحة (سحلول، لونه

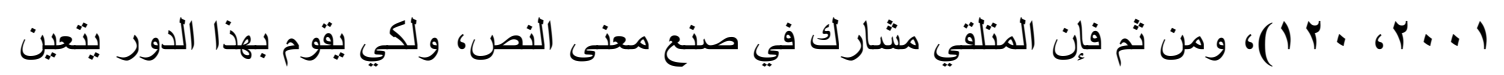

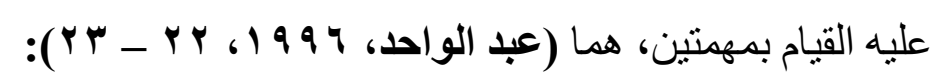

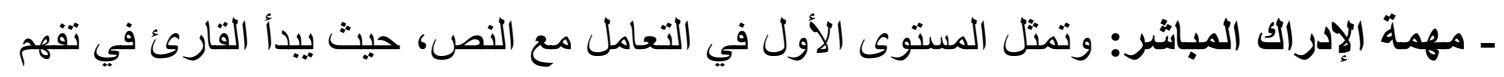

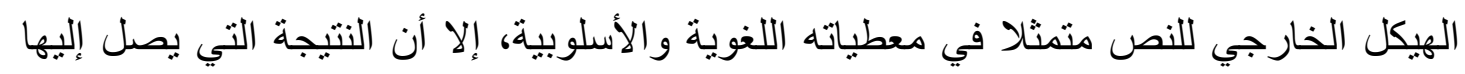

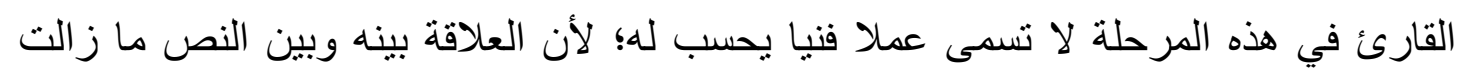
مفصولة أو معزولة بهذا البناء اللغوي.

ـ مهمة الاستذهان: أي عمل الذهن و الخيال، فهي المهمة التي تتشكل فيها ذاتية القارئ، ويكتثف بهن

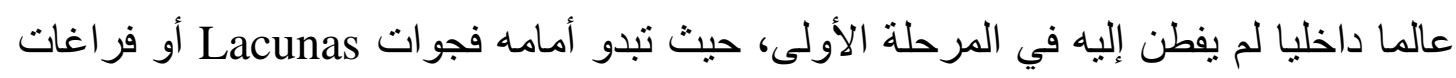

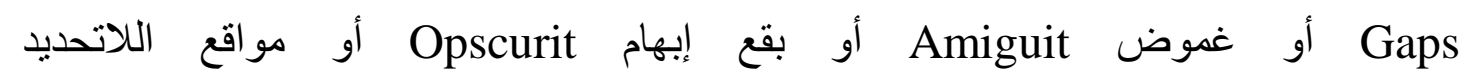

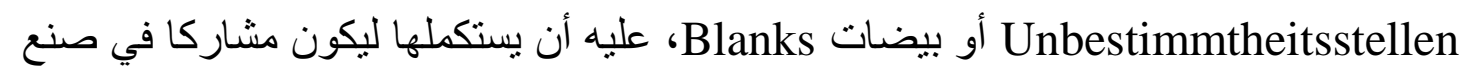

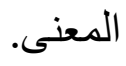
وهذا يعني أن "إيزر" ينظر إلى النص على أنه هيكل عظمي أو جوانب تخطيطية نوجد بها

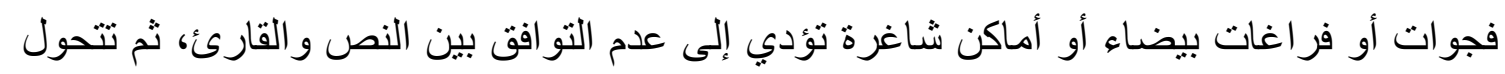

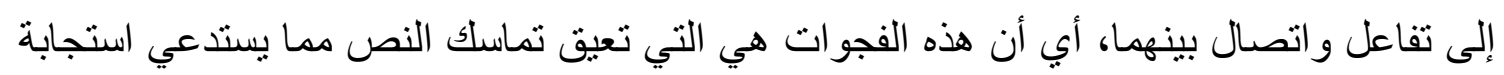

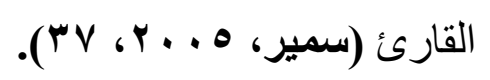

و لا يجب اعتبار فجوات النص مواطن ضعف أو قصور تحسب نقديا على العمل الأدبي؛ وذللك لأنها سِمَة رئيسة فيه، بل يجب النظر إليها على أنها نشاط قصدي من قبل المؤلف، يهدف من ور ائه 
إلى ترك مساحة كبيرة من الخيال للقارئ لكي يملأ من خلاله فر اغات النص (إسماعيل، 991 19،

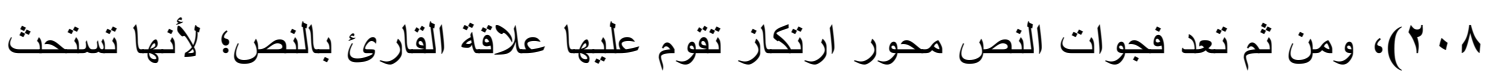

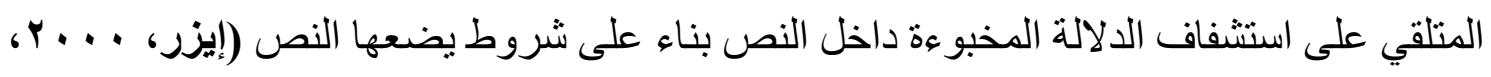
ع ا V )، أي أن القارئ يسهم في إنتاج معنى النص بتوجيه من بنيات النص الداخلية؛ لأن هذه البنية

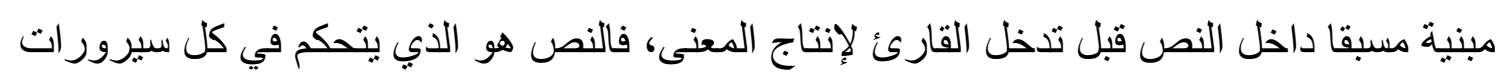

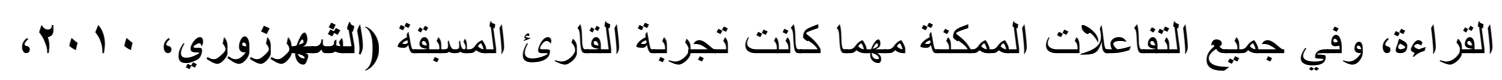

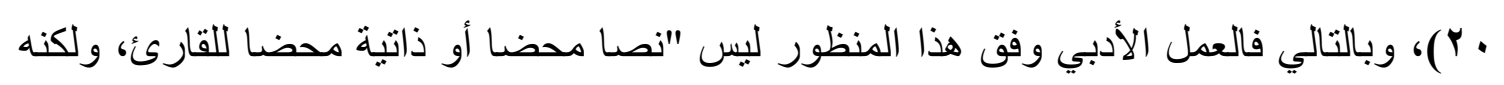

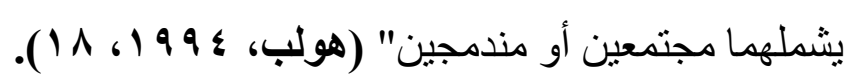

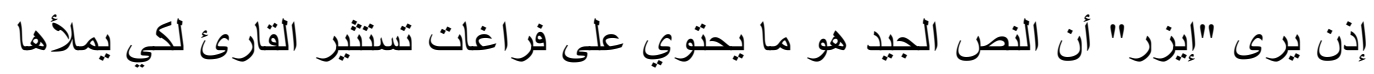

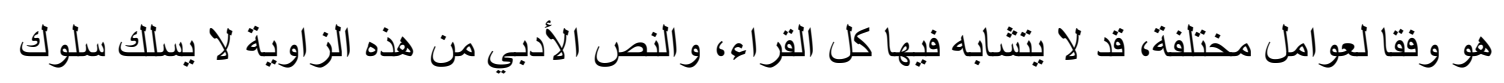

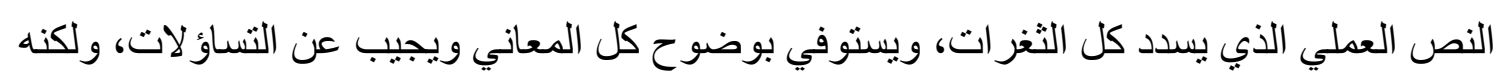
نص يتضمن الفراغات التي تذهب فيها النفس كل مذهب كما يقول البلاغيون القدماء، أو يعتبر

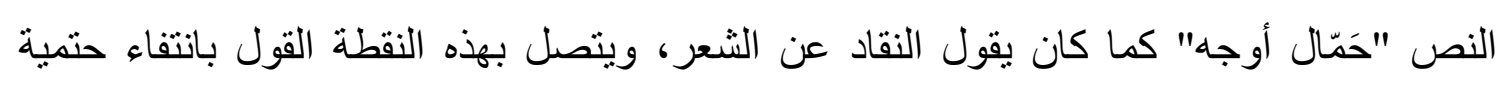
المعنى الموحد الصادر عن النص، وانفتاح النص من جديد، حسب إمكانات بنياته الجمالية

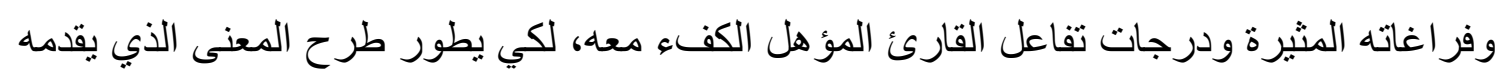

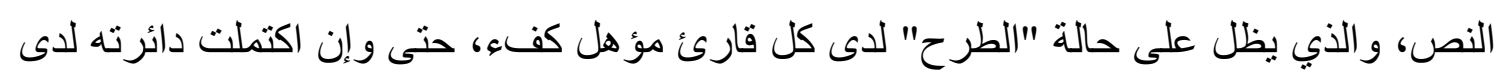

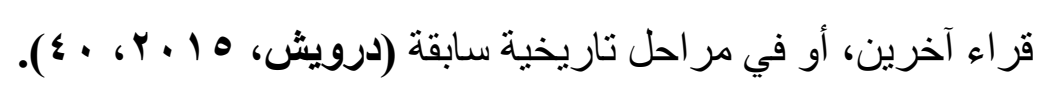

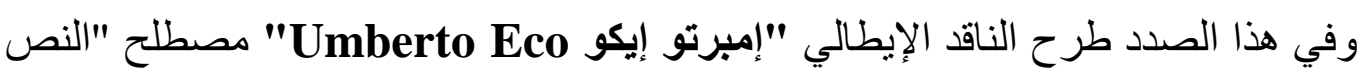

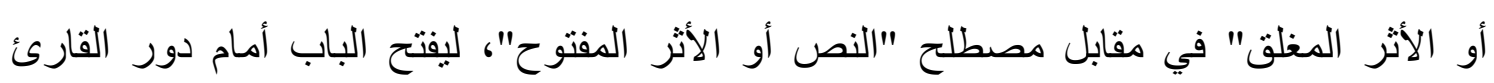

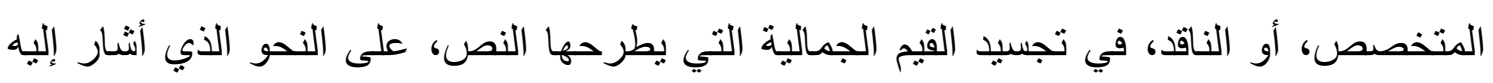
"إيزر"، فالنص المفتوح يسمح لمتلقيه بإعادة إنتاجه حسب فهمه وخبر اتها وكئه وكفاياته الأدبية و النقدية،

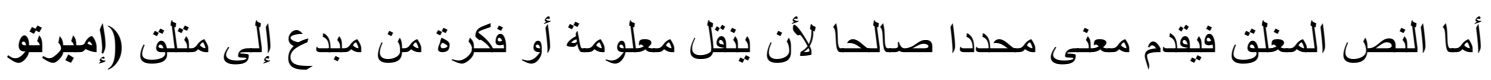

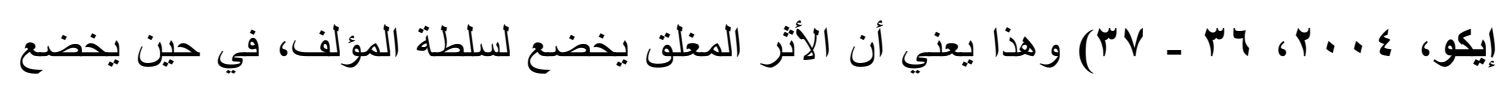
النص المفتوح لسلطة المتلقي. 
وتتمثل البنيات النصية Textual Structures التي يمكن أن تحدث فيها فجوات تستدعي تدخل القارئ ليملأها في ضوء أفق توقعاته في عدة مناطق، هي (هالين، شويرفيجن، أوتان،

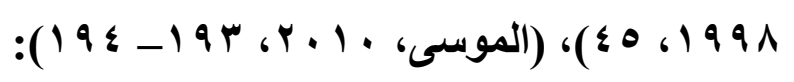

- تغييب لفظة من الألفاظ الدالة على التضاد المعنوي.

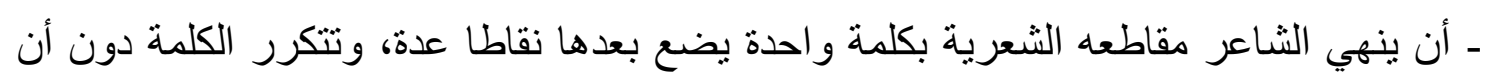
تفصح عن مدلول محدد، بل هي تعطل أحيانا مدلول المقطع نفسه، ليترك للقارئ فرصة لأل بأن يعبئ هذه الفر اغات حسب ما يرتئيه بمساعدة السياق نفسه.

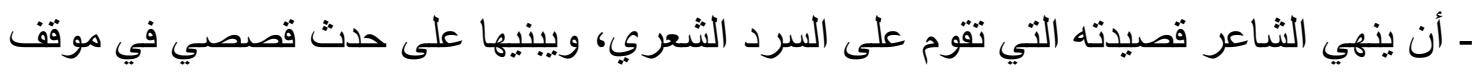
إنتكالي يحتاج إلى حل تفترضه مخيلة القارئ بمساعدة السياق.

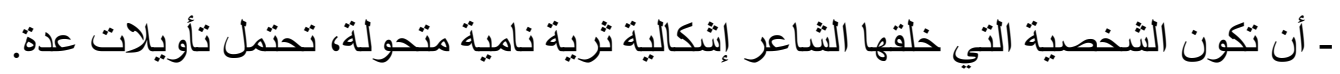

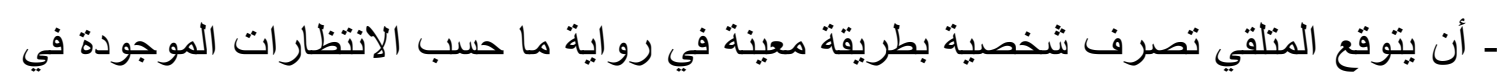
أفقه وتثمل معايير السلوك والعادات والتقاليد، وحينما يجيء سلوك الثخصية مخالفا لأفق توقعاته يقوم بعملية تعديل أو تكييف.

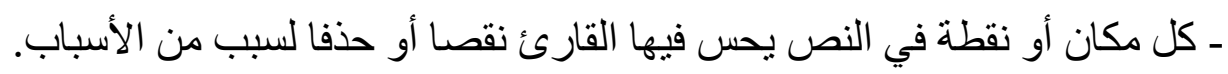
ـ كل مكان أو نقطة في النص تعمد المؤلف إسكات شئ ما لتفعيل مشاركة القارئ. ـ كل لفظة أو جملة في النص يخفق القارئ في تحديد دلالاتها المتعارفة من أجل كسر أفق توقعه وتنشيط وعيه.

ـ أن يترك المؤلف صفحات فارغة (بيضاء) في نهاية كل فصل من فصول القصة وفي بداية

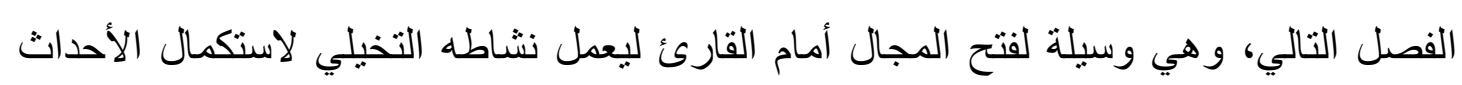
و إعادة تنظيمها من أجل المساهمة في بناء النص وتحقيق الفهر.

وفي ضوء مفهوم فجوات النص يمكن اشتقاق بعض الكفايات النقلية المتعلقة بهذا المفهوم : ـ يملأ فجو ات النص لإعادة بنائه و إنتاج معناه.

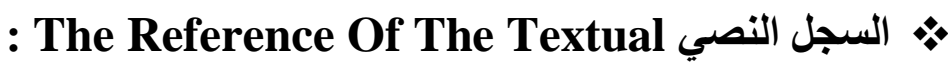

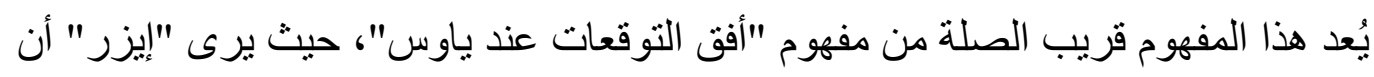

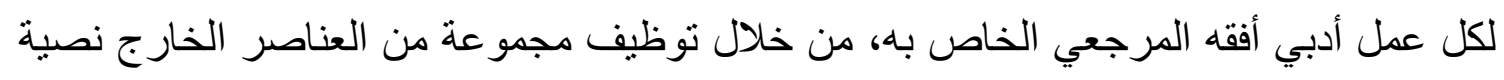

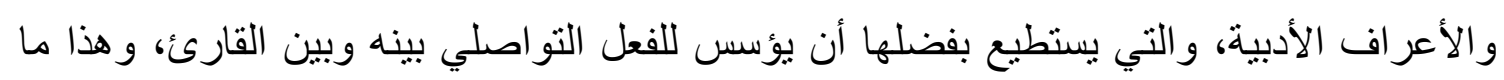


يسميه "إيزر" بسجل النص أو رصيد النص أو ذخيرة النص أو مرجع النص أو موسوعة النص . . . . بله

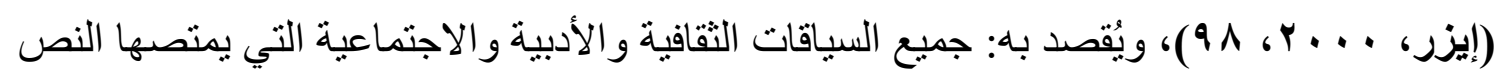
ويجمعها ويخزنها في ذاكرته وتترسب في فضائه ويعيد بنائها بما تضفي عليه قيمته الدينامية

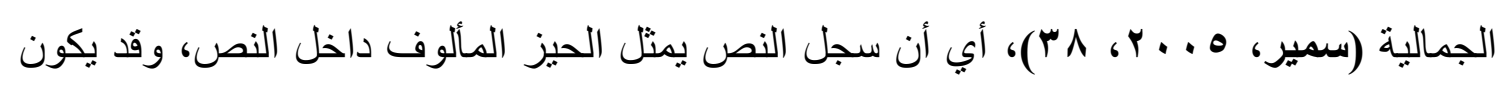
على شكل إثارات لأعمال ونصوص سابقة، أو إلى معايير اجتماعية وتاريخية، أو إلى مجمل التصل

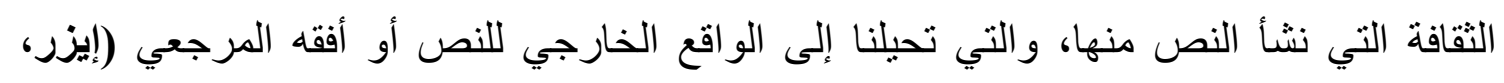

$$
\text { ( }(\mathrm{D} 0, \mathrm{Y}, \ldots
$$

ولعل مفهوم السجل هو نفس مفهوم "السياق Context" الذي استخدمه النقاد العرب القدماء، ومعرفة هذا السياق مُسَّمَّة نقدية؛ حيث يعد شرطا للإبداع و التلقي، فالكاتب لن يبدع إلا إذا أتقن

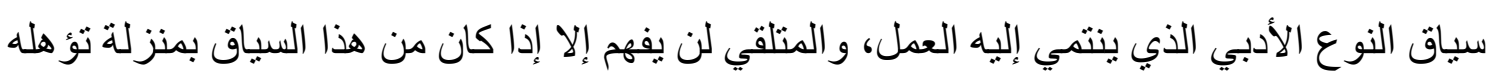

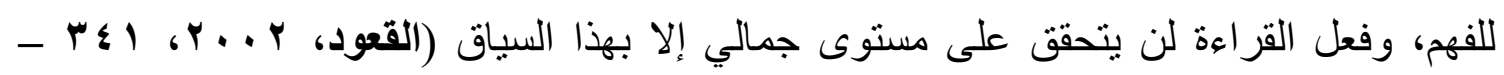
. (r $r$ r

وفي ضوء مفهوم السجل النصي يمكن اشتقاق بعض الكفايات النقاية المتعلقة بهذا المفهوم : - يؤول النص في ضوء سياقه اللغوي و الأدبي.

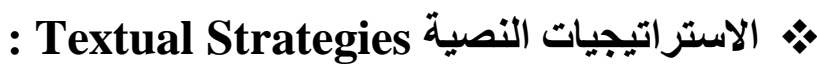

و إذا كان لكل عمل أدبي سجل أو رصيد يمتص فيه معايير وقيم اجتماعية وثقافية وتاريخية

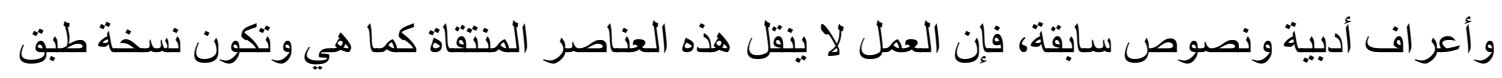
الأصل، بل تُنزع من سياقاتها وتدخل في سياق نصي جديد، بحيث تكتسب أبعادا دلالية مغايرة

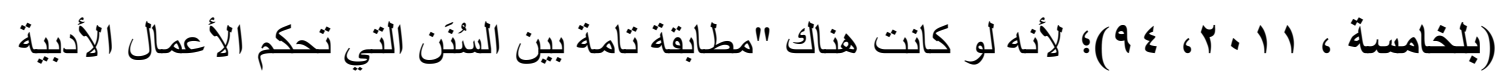

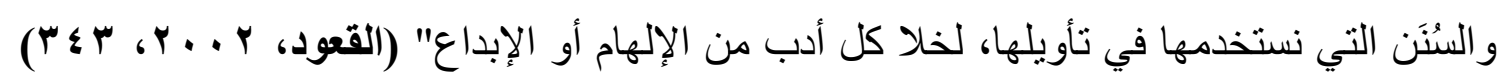

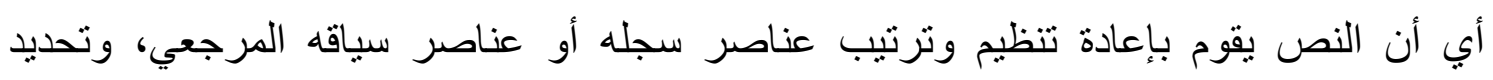

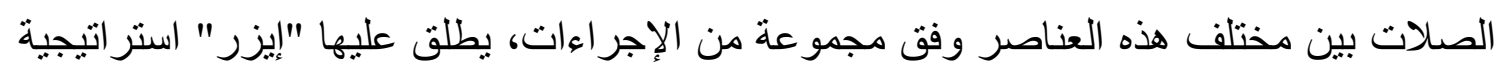

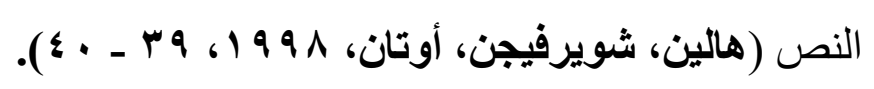

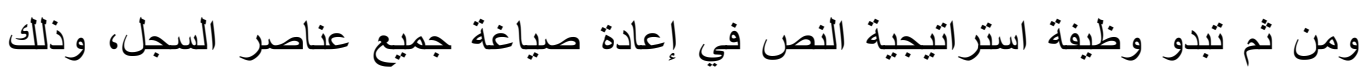
بمخالفة المعايير الأدبية المتعارف عليها، والانحر اف عن النموذج القياسي والمبادئ الثابتة المألوفة 
وتحطيمها ؛ مما يؤدي إلى رسم معالم موضوع النص ومعناه من جهة، وتنظيم شروط التواصل

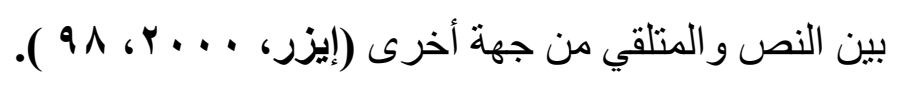

وفي ضوء مفهوم الاستراتيجيات النصية يمكن اشتقاق بعض الكفايات النقدية المتعلقة بهذا

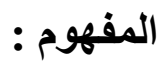
- يحكم على أدبية النص في ضوء سياقه المرجعي.

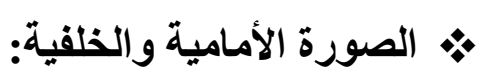

يرى "إيزر" أنه في ضوء الأدوار المهمة لكل من السجل النصي والاستر اتيجيات النصية،

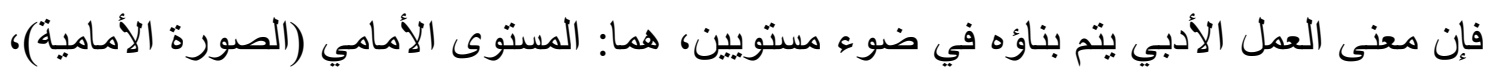

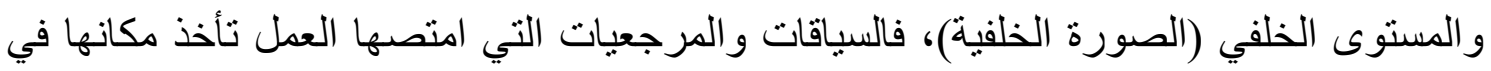
الصورة الخلفية، أما الدلالات الجديدة لتلك السياقات و المرجعيات فتأخذ مكانها في الصورة الصوات الأمامية

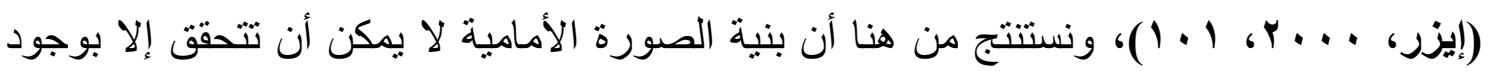

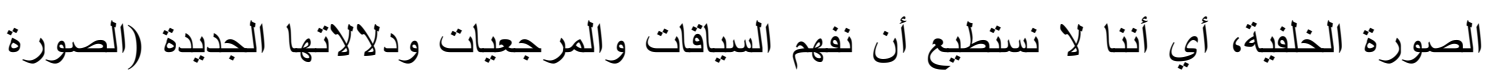
الأمامية) إلا على ضوء الصورة الخلفية التي انفصلت عنها وماز الت مستمرة في إثارتها والإنشارة

و هكذا يجد المتلقي نفسه أمام مستويين متناقضين للمعنى؛ مستوى مو افق لأفق توقعاته (الصورة الخلفية)، ومستوى آخر مخالف لهذا الأفق (الصورة الأمامية) مما يسبب له نوع من التوتر و الانفعال يدفعه إلى تفعيل كفاياته النقاية للتأويل و المساهمة في إنتاج النص. لهن.

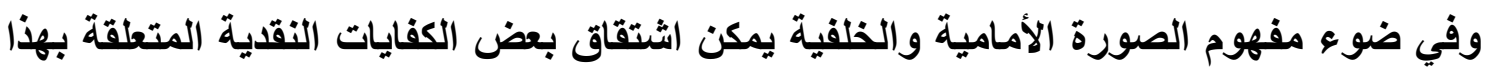

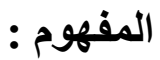

ـ يحدد العلاقة بين الصورة الأمامية و الخلفية لبناء معاني النص وتأويلها.

: بارئ الضمنى The Implied Reade:

ينطلق "إيرز" في تصوره لتلقي العمل الأدبي من فكرة مفادها أن النص لا يعدو أن يكون

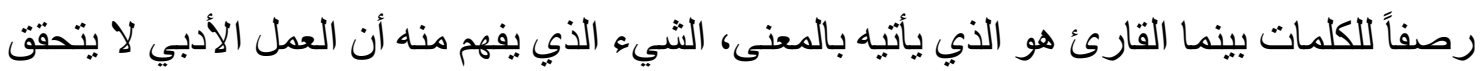
من تلقاء نفسه، و إنما استنادًا إلى فعل إنجازي يقوم به قر اء ومتلقون، ولذلك يطلق "إيرز" على هذه القوة التي تحول النص من بنية الكمون إلى بنية الفعل و التحقق اسم القارئ الضمني. 
ويعتبر "إيزر" أن مفهوم القارئ الضمني من أهم الأسس الإجرائية لوصف العلاقة

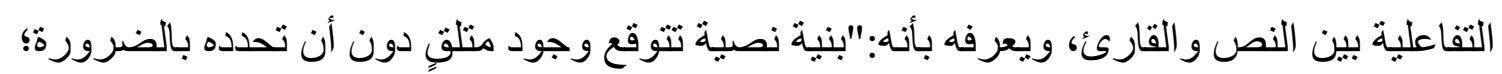

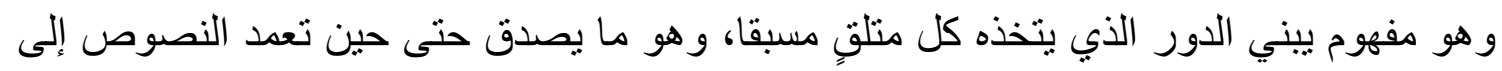

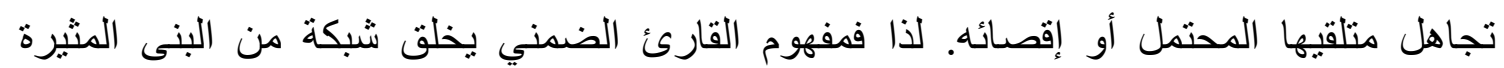

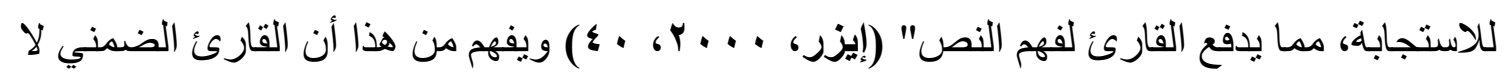

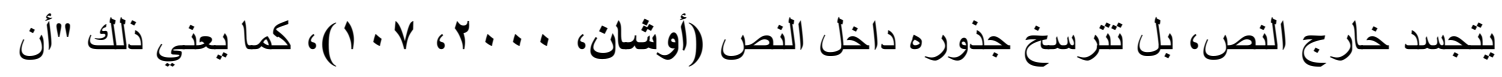
القارئ الضمني موجود قبل بناء المعنى الضمني في النص، وقبل إحساس المتلقي بهذا التضمين

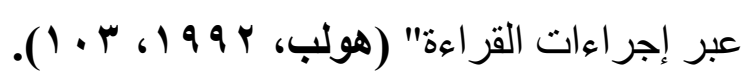

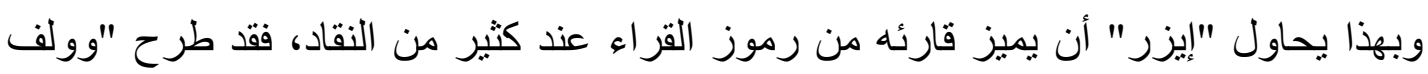

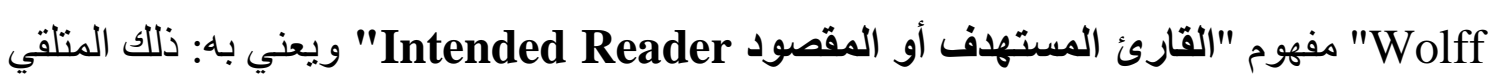
الذي يتثكل في ذهن المؤلف عند إبداعه للعمل الأدبي، باعتباره يجسد تقاليد ومعايير المتلقيين

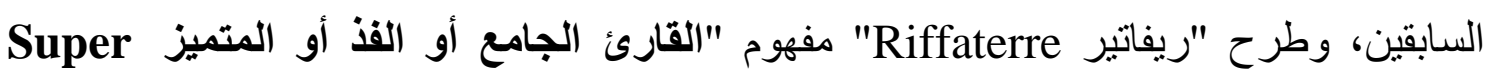
Reader" و هو ذلك المتلقي الذي يمتلك قدرة إدر اكية عالية على فهم النص الأدبي وتمييز حقائقه

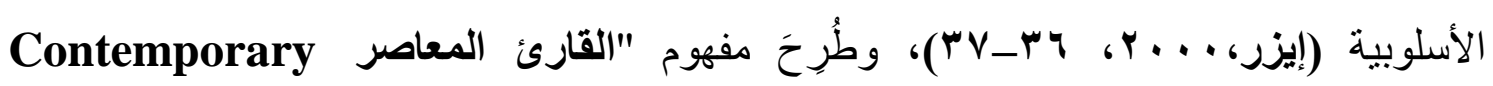

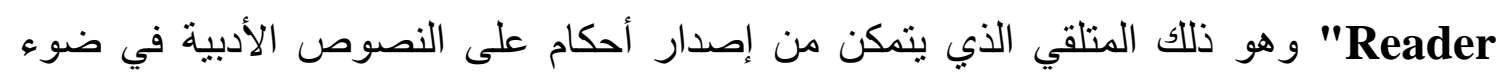

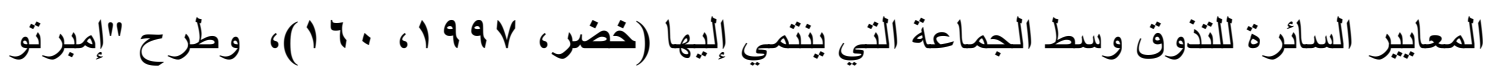

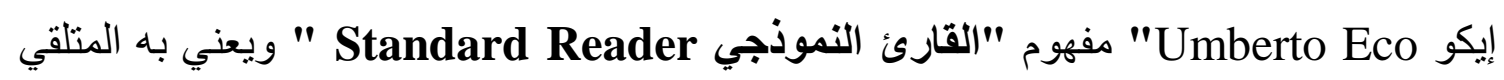

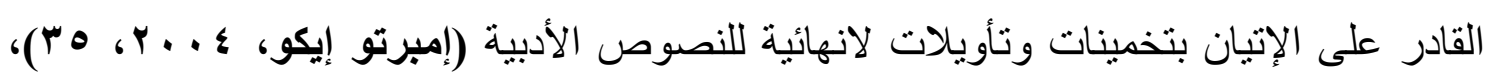

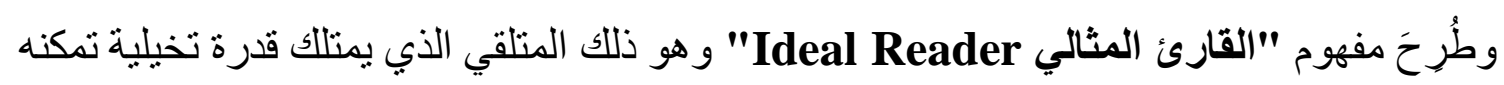
من فلك الثفرات المتحكمة في نظام النص، والكثف عن مكنونات ومضامين متغايرة بحسب

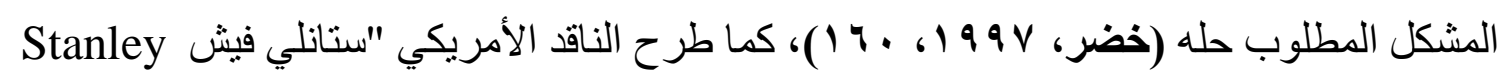

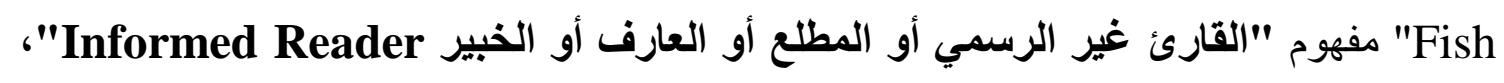

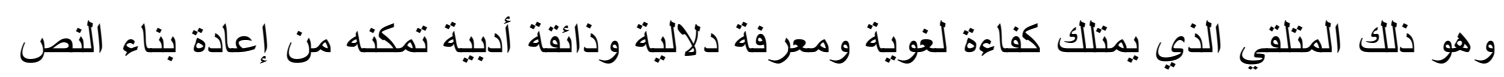

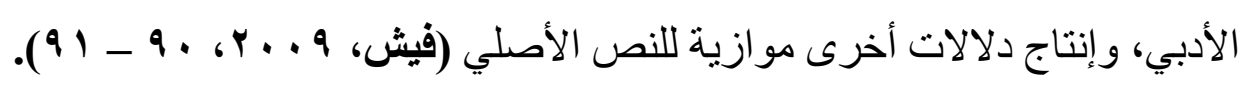

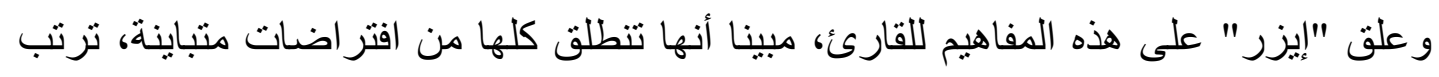

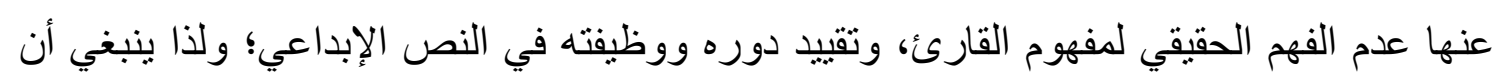

\section{$1 \cdot r$}


نحرر القارئ ونسمح بوجوده دون تحديد مسبق لطبيعته أو موقفه التاريخي، ولكننا نستطيع أن نرسم لله ملامح تقريبية بناء على صورتين اثنتين يكون عليهما، إحداهما: نصية تتجلى في بنية النص، وثانيهما: تتجسد في بنية فعلية تستدعي تجاوبا ينتج عنه فهم وتأويل، وبهذا المفهوم يكون بناه للقارئ الضمني في نظر "إيزر" مظهران منر ابطان: الأول ذو معنى تجريدي يتبدى في صورة نمطية مثالية، تحضر في جميع النصوص التي تتنمي إلى حقبة فنية داخل ثقافة ما، في حين يكون

الثاني مجسدا في قارئ كفه له وجود فعلي؛ ويملك مقدرة على التفاعل (إيزر، . . . ب، . ؛). ويمكن أن نتلمس - بصورة إجرائية - حضور القارئ الضمني في العمل الأدبي من خلال

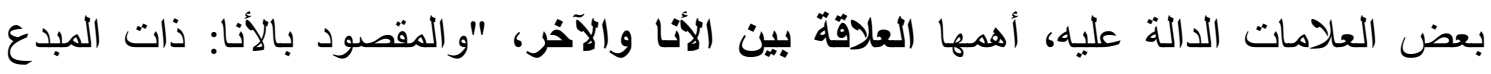

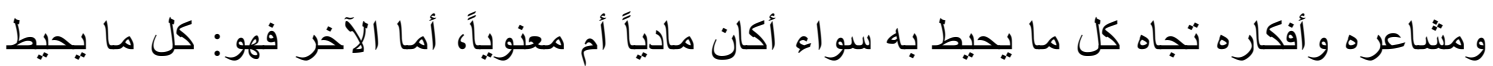
بالمبدع، أو كل ما هو خارج ومختلف عن ذاته سواء أكان هذا الآخر شخصاً أو شيئاً مادياً أم فئاه

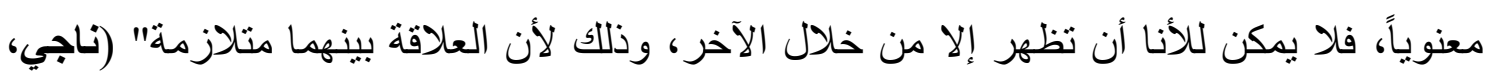

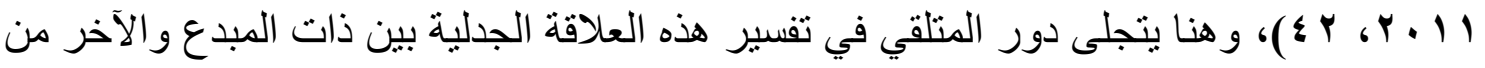
خلال رصد الدلالات المحتملة على ضوء اللامنوقع في مكوناتها، وبالتالي ضمان مشاركته في لهني العملية التو اصلية لتفعيل القر اءة وتثكيل معنى العمل الأدبي.

وفي ضوء مفهوم القارئ الضمني يمكن اثتقاق بعض الكفايات النقدية المتعلقة بهذا المفهوم:

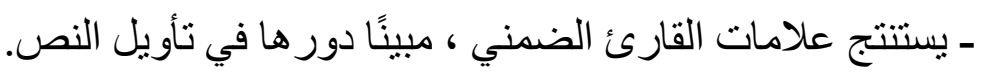

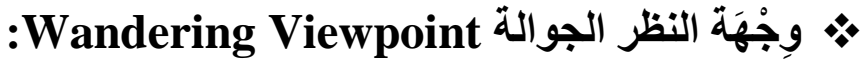

يوظف "إيزر" هذا المفهوم انطلاقا من مسلمة نقدية مفادها أن النص الأدبي لا يمكن إدر اكه و استيعابه دفعة واحدة، بل يتشكل في وعي القارئ تدريجيا خلال مر احل القراءة، إذ ينتقل القارئ عبر مختلف البنى النصية، ويمثل كل انتقال من بنية نصية معينة لحظة أو مرحلة جديدة من مر احل القر اءة، وسوف يتحتم على القارئ أن ينسق ويؤلف عند كل انتقال جديد بين البنى النصية

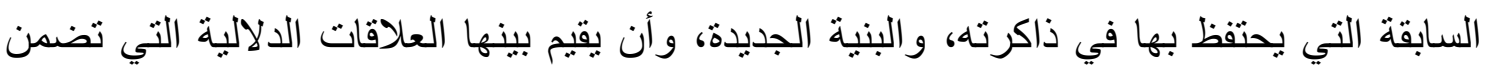

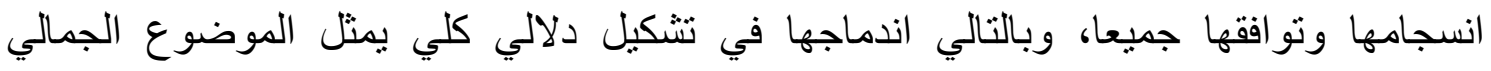

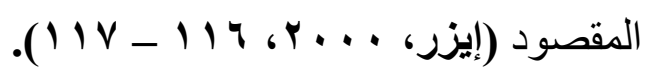

ومن ثم تبدو وظيفة وجهة النظر الجوالة (وجهة النظر الثاردة، نقطة الروئة المتحركة) في أنها تسمح للقارئ بالسياحة في النص فيكثف العلاقة بين طبقات Stratum العمل الأدبي على لهى 
مستوى الأصوات و الكلمات و الجمل و الأفكار و المعاني و الصور والربط بينها لإنتاج المعنى العميق للنص (إسماعيل، 991 199، ؛ ـ 1).

ويمكن أن نحدد - بصورة إجر ائية - دور المتلقي في العمل الأدبي من خلال مفهوم وجهة النظر الجوالة، ففي مجال الثعر مثلا يقوم المتلقي بفهم دلالة الرموز، وتحديد الدلالة الإيحائية

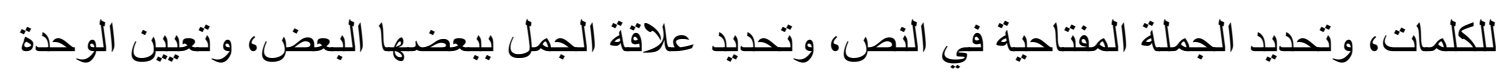

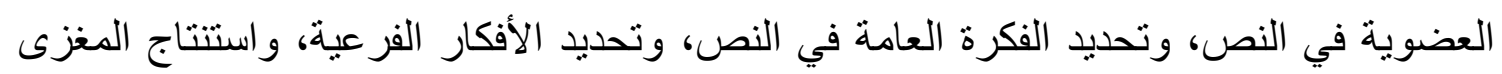
من وراء عنوان النص، واكتشاف تلميحات النص، فكل هذه الآليات الإجرائية تمكن المتلقي من فن قر اءة المعاني الغائبة في النص. وفي ضوء مفهوم وجهة النظر الجوالة يمكن اشتقاق بعض الكفايات النقية المتعقة بهذا المفهوم: المئ مون ـ يكتثف العلاقة بين طبقات العمل الأدبي ، موضحًا أثر ها في إبر از تماسكه و إظهار وحدثه

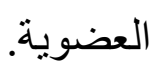

\section{• : التراكيب السلبية Passive Synthesises:}

إن عمليات الفهم التي تنتج عن وجهة النظر الجوالة تنظم انتقال النص إلى العقل الواعي

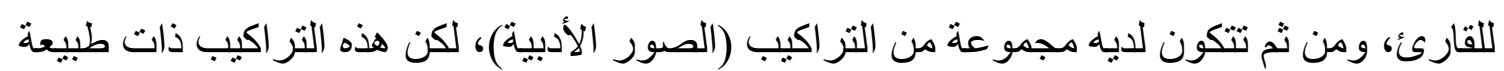

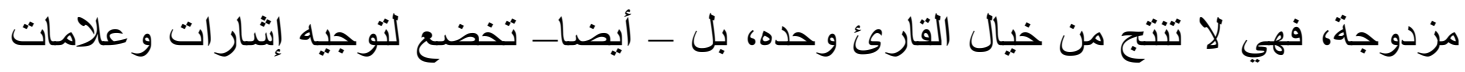

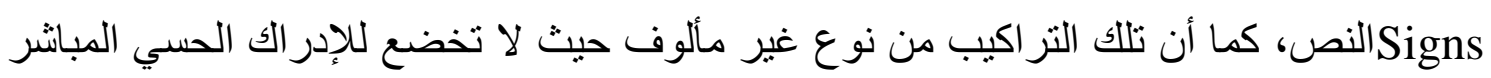

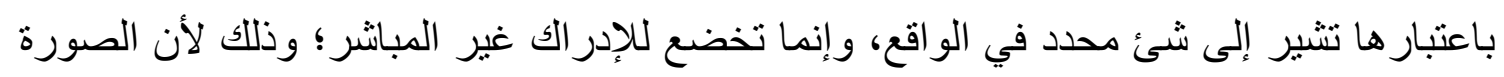

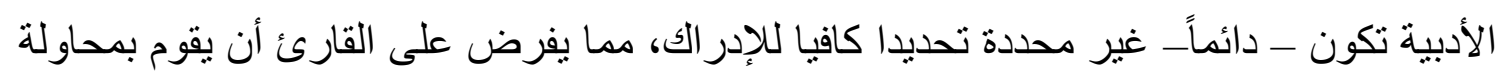
تصور Ideate ما لا يمكن أن ير اه في صورته الفعلية؛ ومن ثم فهذه النر اكيب تتصف بأنها سلبية فئرية

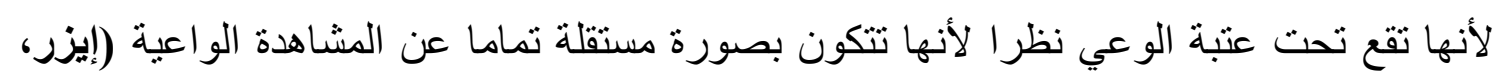

\section{. ( $1 \leqslant$ r r . . . .}

و على هذا، يقصد بالتر اكيب السلبية: التداعيات الحرة التي تتشأ في ذهن المتلقي عند قر اءته

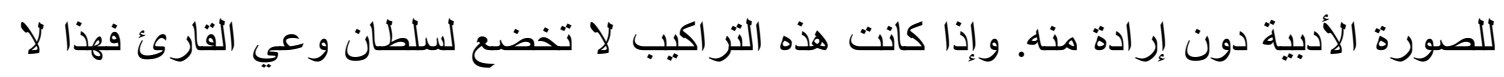

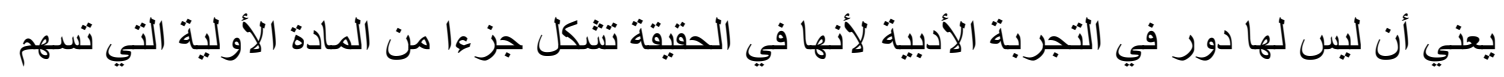

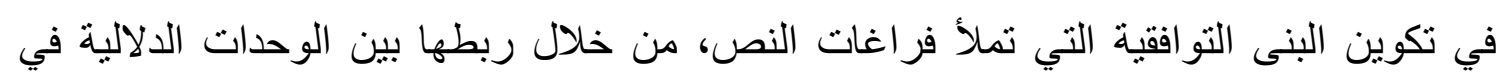


النص، بمشاركة القارئ، ليتم التفاعل المطلوب بين النص و المتلقي. من هنا نجد أن دور ها يتمثل

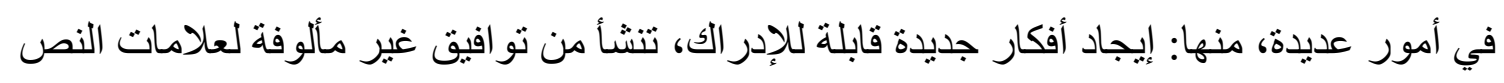

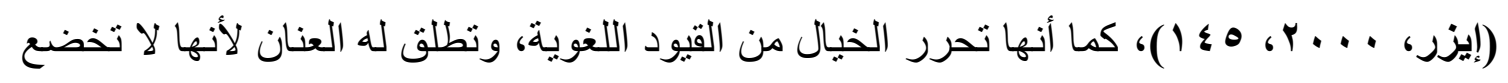

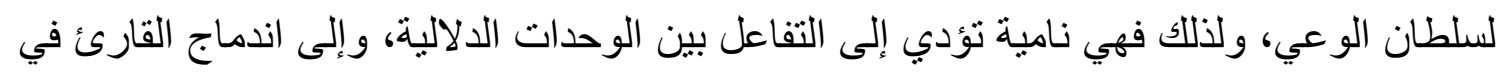

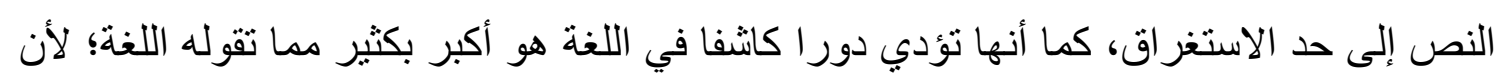

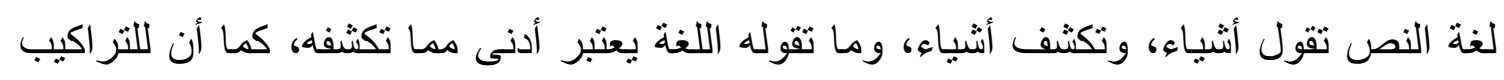
السلبية طابعا مهجنا، فهي تصورية في لحظة، ودلالية في لحظة أخرى، ولذلك يستحيل أن تتكرر

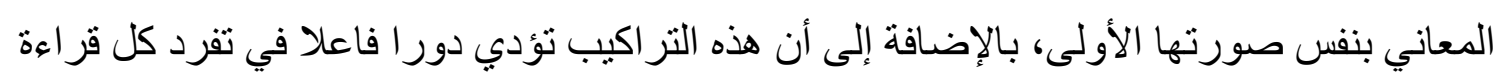

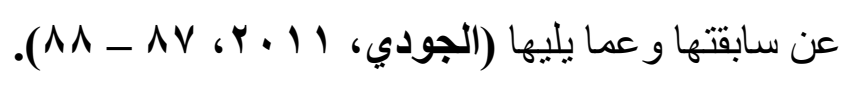

ويمكن أن نحدد - بصورة إجرائيةــ العنصر الرئيس للتراكيب السلبية حيث يتمثل في الصور الأدبية التي تتشكل لدى المتلقي في أثناء قراعته للنص، بما تتضدنه من ألوان بلاغية

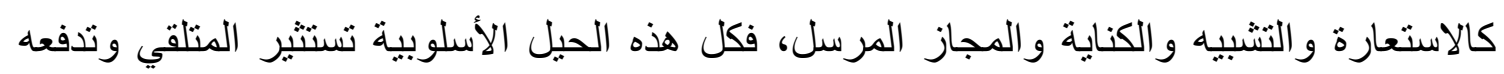
لتأويل النص. وفي ضوء مفهوم وجهة النظر الجوالة يمكن اشتقاق بعض الكفايات النقدية المتعلقة

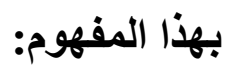
- يبرز التر اكيب السلبية في النص محددا أثر ها في تكوين صوره العميقة. • المحور الثاني : نظرية التلقي : دواعي ظهورها ، وافتراضاتها الأساسية ، ومبادؤها :

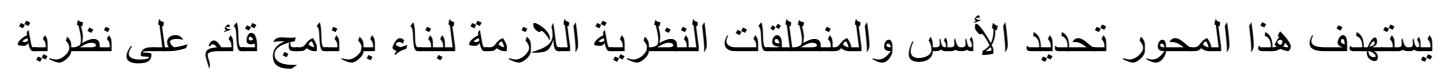

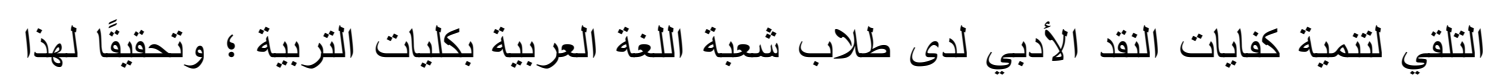

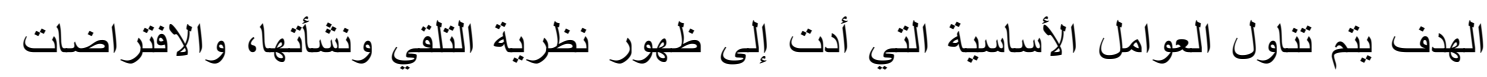
والمبادئ التي أسس في ضوئها رائدا النظرية ( ياوس ، و إيزر ) التلقي الأدبي، وفيما ليلى عرض فئي

أولًا : العوامل التي أدت إلى ظهور نظرية التلقي :

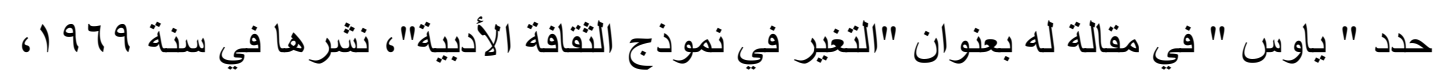

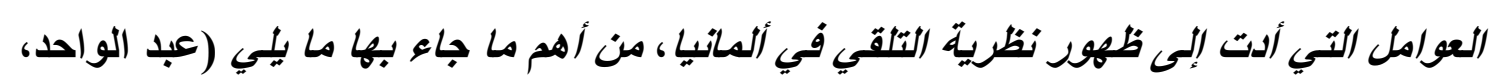

$$
\text { : (1. - } 99 \text { ، 1999 }
$$


ـ الاستجابة لأوضاع جديدة فرضت إحداث تغييرات جذرية للمناهج و البرامج الأكاديمية الجامعية في مجال تعليم الأدب و اللغة، مما جعل جميع الاتجاهات ـ على تباينها - تستجيب للتحدي.

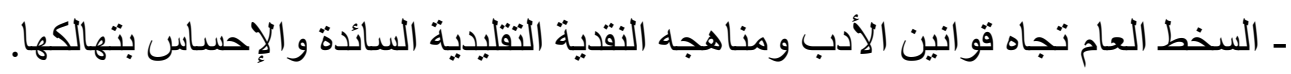
- حالة الفوضى و الاضطر اب السائد في نظريات الأدب المعاصرة. - وصول أزمة الأدبية خلال فترة المد البنيوي إلى حد لا يمكن قبوله واستمراره، وكذا الثنورة المتنامية ضد الجوهر الوصفي للبنيوية. ـ ميول وتوجه عام في كتابات كثيرة نحو القارئ بوصفه العنصر المهمل في عملية التو اصل الأدبي

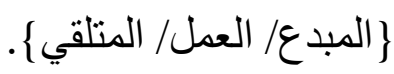
وفي ضوء العوامل التي أدت إلى ظهور نظرية التلقي ، يمكن اشتقاق بعض أسس بناء البرنامج المقترح في الاراسة الحالية :

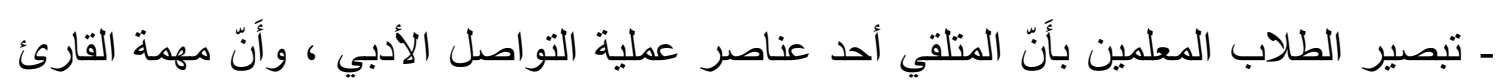

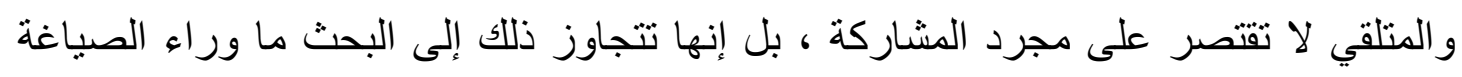

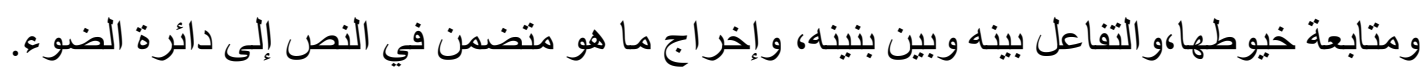

\section{ثانيًا : الافتراضات الأساسية التي قامت عليها نظرية التلقي :}

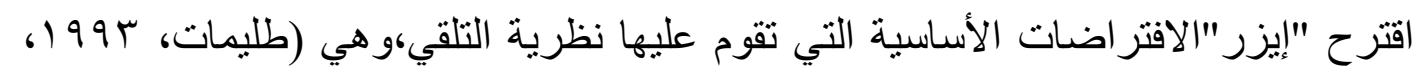

:(10r

ـ النص ليس هو المعنى،بل هو ذللك الوسيط الضروري الذي يمكن القارئ من بناء معنى النص. ـ ـ المعنى ليس سابقا على تدخل القارئ. ـ التلقي يخرج المعنى من حالة الكمون إلى حالة التجسيد.

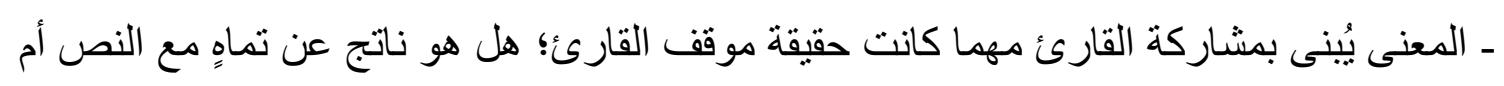

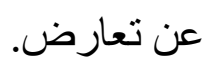
- بداية تكوين المعنى وتأسيسه هي تللك النقطة التي يلتقي عندها النص بالقارئ. وفي ضوء الافتراضات الأساسية التي قامت عليها نظرية التلقي ، يمكن اشتقاق بعض أسنائ أسس بناء البرنامج المقترح في الاراسة الحالية : 


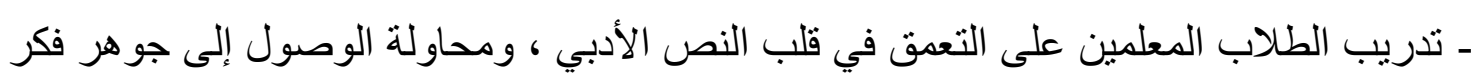

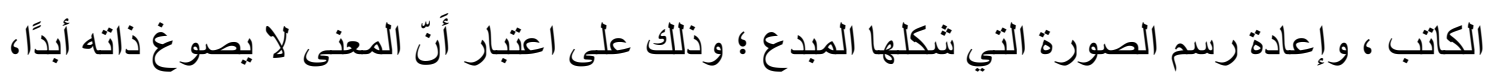

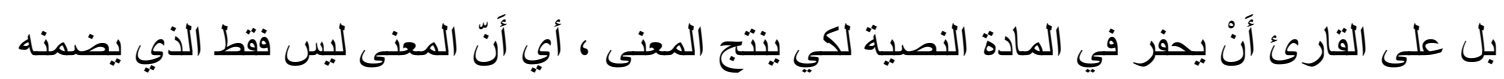

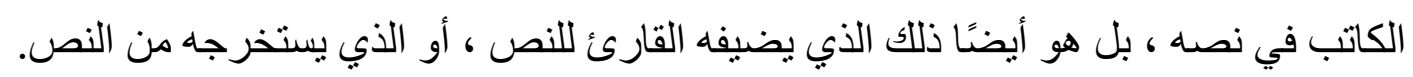
ثالثًا : مبادئ نظرية التلقي : سعى "ياوس" إلى بناء نموذج أو نظرية أو منهج نقدي جديد، بنطلق من عدة مبادئ، هي (خضر،

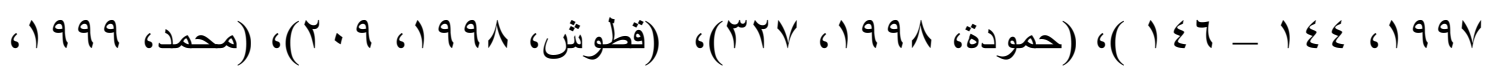

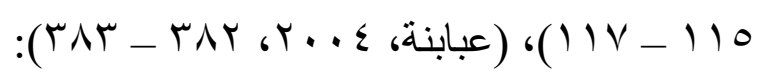

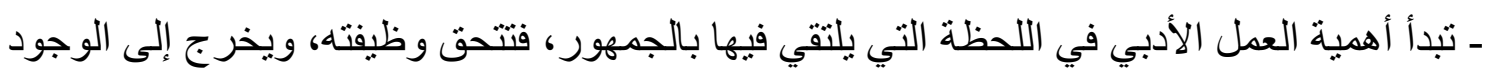

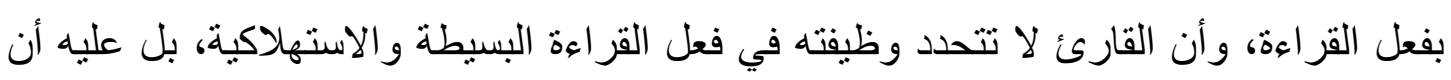

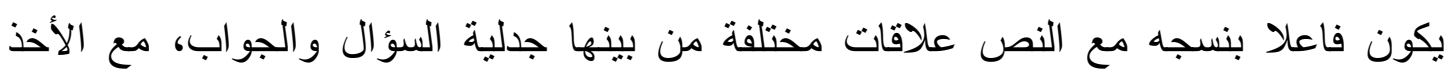
بالاعتبار لأهمية الأحكام التي تم إصدار ها، و هذا ما يؤكد أهمية المبدأ التعاقبي في عملية تاريخ الأدب. ـ تعد القر اءة عملية منتجة وذات فعالية وليست مجرد استجابة، ومتعة القارئ تبدأ عندما يصبح هو

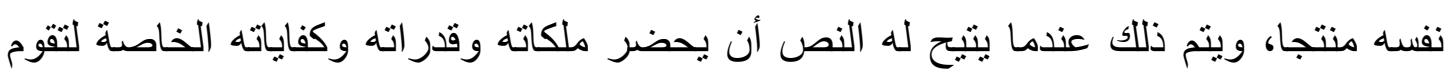

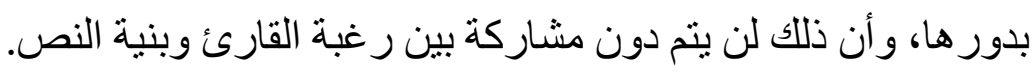

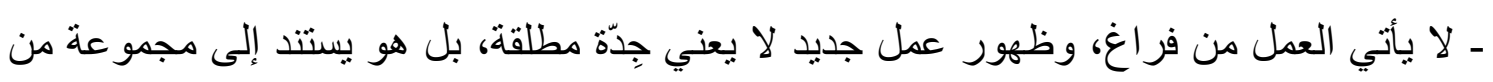

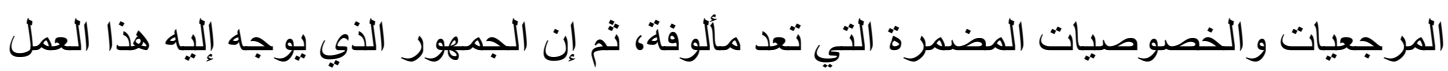
هو جمهور مسلح بمجموعة من المعايير اكتسبها عبر تجاربه الخاصة مع النصوص السابقة، ويستدعي العمل بشكل ضمني مجموعة من القراءات، واضعا المتلقي في حالة انفعالية معينة،

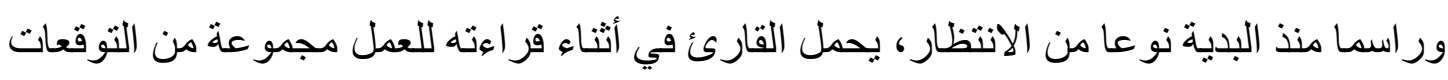

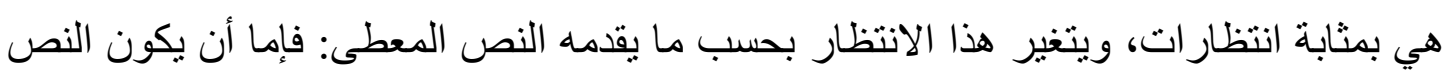

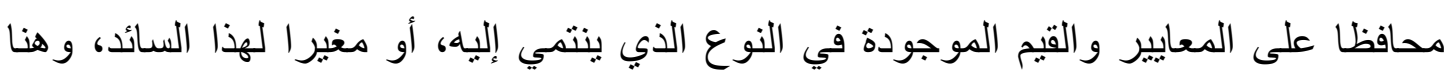

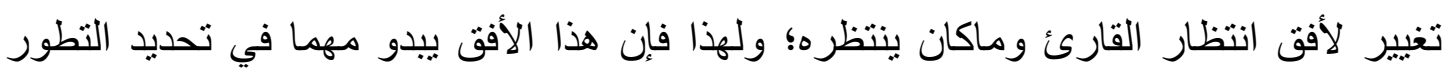
الأدبي في الأشكال و المضامين.

\section{V}


- ينبغي تتخيص الإجابات التي يقدما العمل الأدبي لأسئلة القُرّاء عبر فترات تاريخية متفاوتة، و هذا يدل على أن كل عمل جديد يشمل في طياته رغبات المتلقي في تعديل شروط الاستجابة و والتو اصل.

- يتعين تحديد وضعية العمل الأدبي في إطار السلسلة الأدبية التي ينتظم فيها، إذ تفترض جمالية

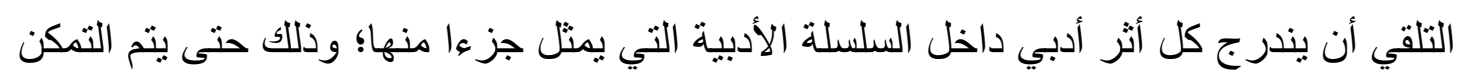
من تحديد وضعيته التاريخية وأهميته أو دوره داخل السياق العام للتجربة الأدبية.

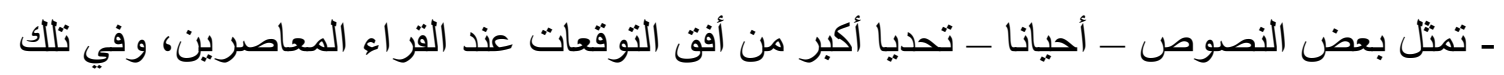
الحالات فإن على تلك النصوص أن تنتظر اليوم الذي يجيء فيه قراء تكون أفق توقعاتهم قادرة على فهمها. ـ تعد كل قراءة للنص وصفا نقديا لفهم المتلقي لهذا النص، أب وصف للعلاقة بين المتلقي و النص. ـ ـ تسلم جماليات التلقي بالوظيفة الاجتماعية للأدب، وترى أن قراءة الفرد تؤثر في سلوكه الاجتماعي.

وفي ضوء مبادئ نظرية التلقي ، يمكن اشتقاق بعض أسس بناء البرنامج المقترح في الدراسة الحالية : ـ توجيه الطلاب المعلمين إلى أن نظرية التلقي تمكن القارئ من التفاعل مع النص الأدبي، بحيث

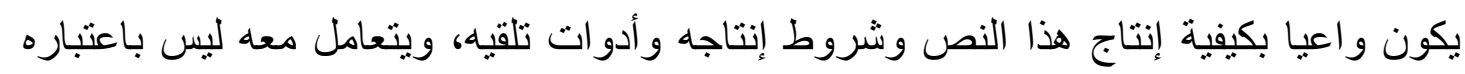

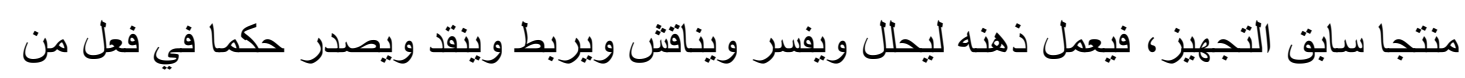

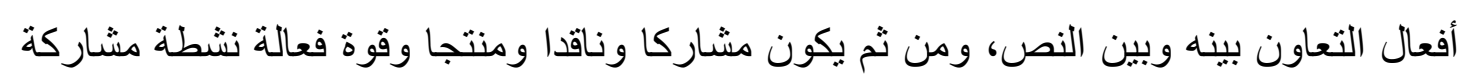
مبدعة للنص. ـ تبصير الطلاب المعلمين بأن قارئ النص الأدبي ليس مجرد مستقبل سلبي، بل هو متلق منتج،

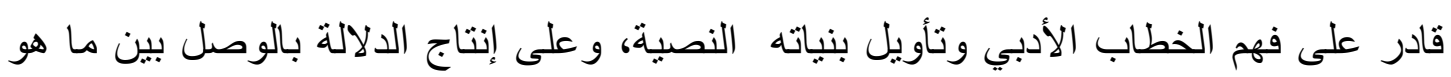
مو افق وما هو مفارق في هذا الخطاب، بين الصريح والضمني، بين المبنين وما هو قابل للبنية.

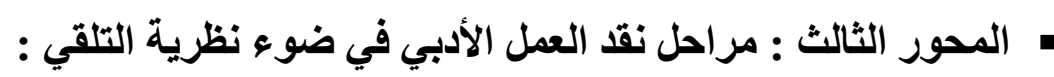

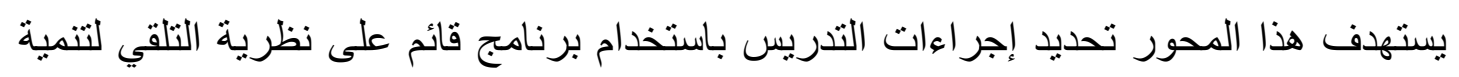

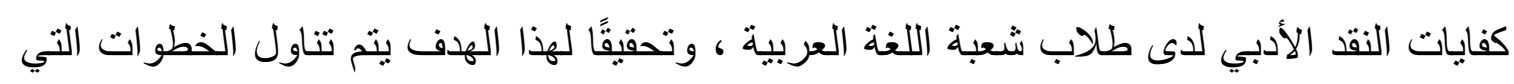


تساعد الطلاب المعلمين على التفاعل مع النص الأدبي استجابةً وتذوقًا ونقدًا و إنتاجًا ، وفيما يلي عرض لذلك. يتفق مؤيدوا نظرية التلقي على أنها تصلح - بما تتضمنه من افتراضات ومفاهيم نقدية ترسم

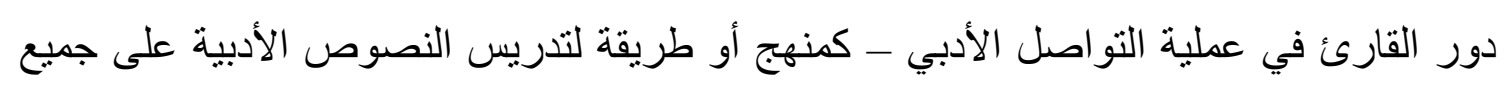

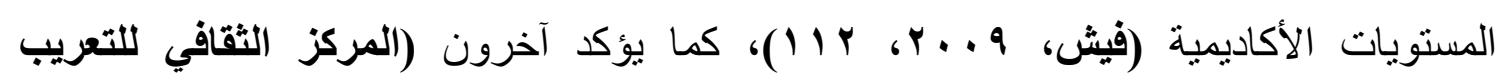

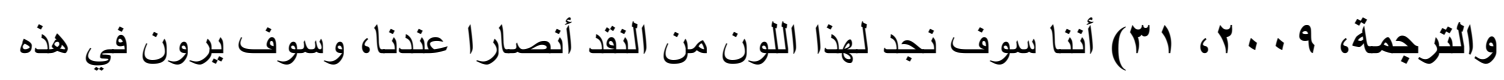

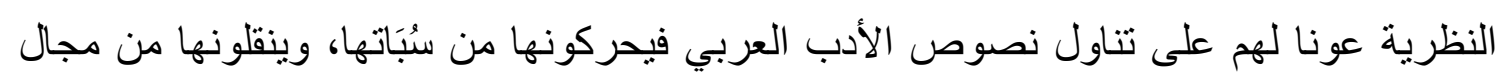

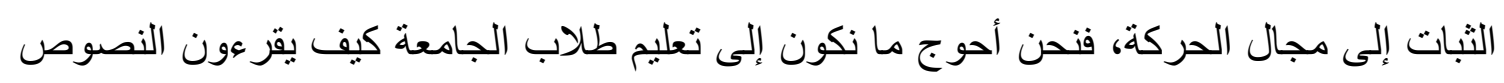

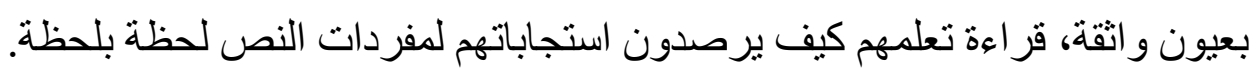

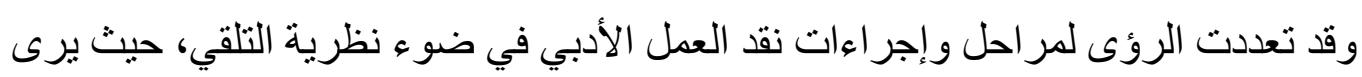

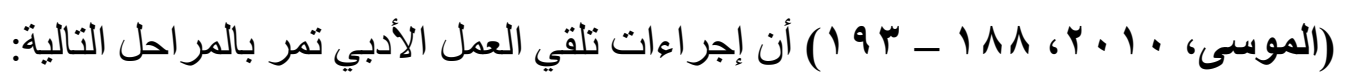

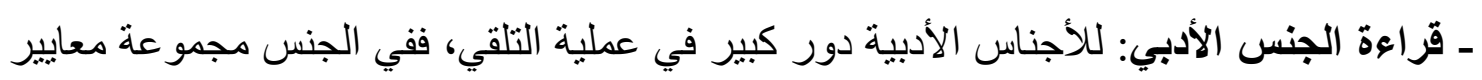

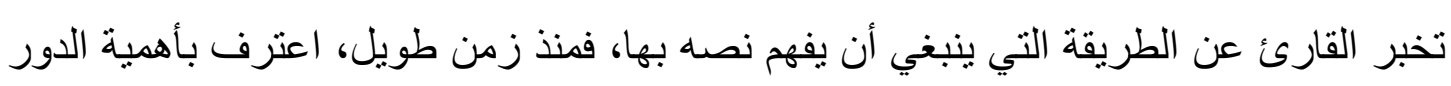

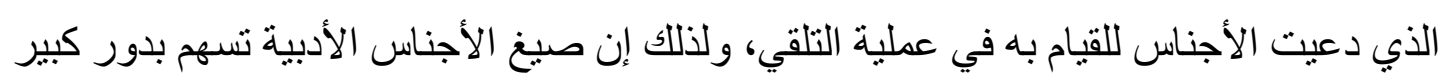
في إلقاء الضوء على معنى النص، فمعاني المأساة غير معاني الكوميديا، وللأجناس الثعرية

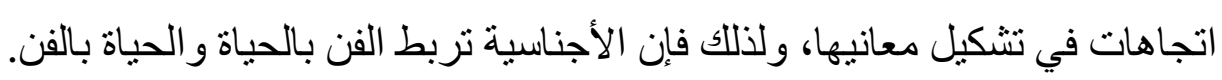

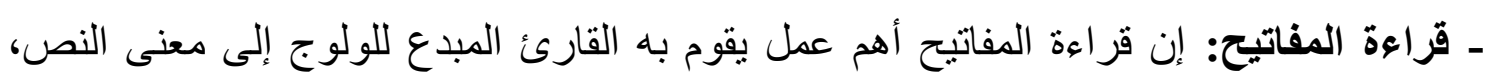

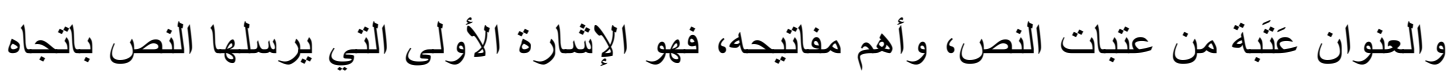

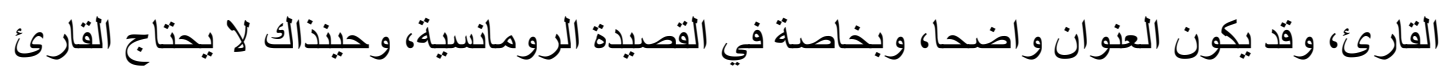

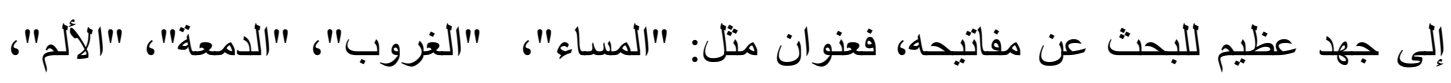

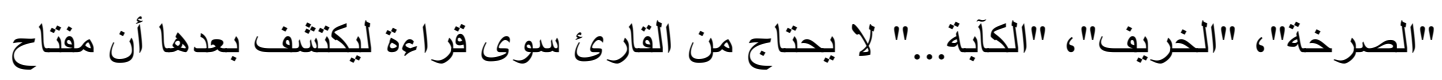

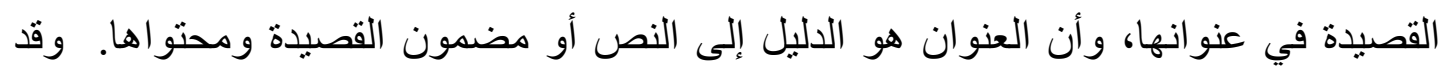

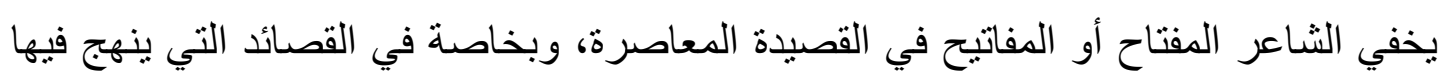

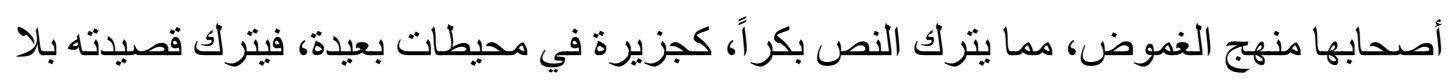

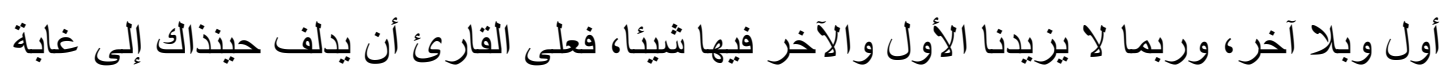

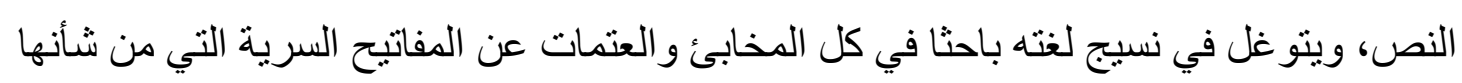

\section{9}


أن تقوده إلى اكتثاف الأبواب و الأدر اج السرية للقصيدة، وقد تكون الدفاتيح في العنوان أو في الخط أو في البياض أو في الفراغ، أو في الخاتمة أو في أب مكان آخر ، وقد تكون في معجمها لأبها

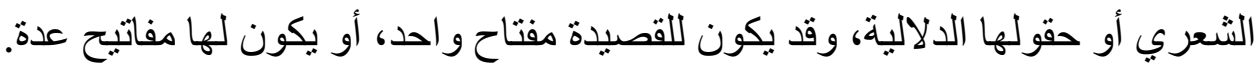

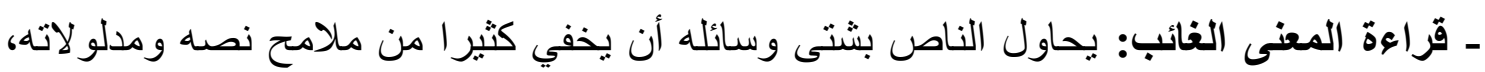

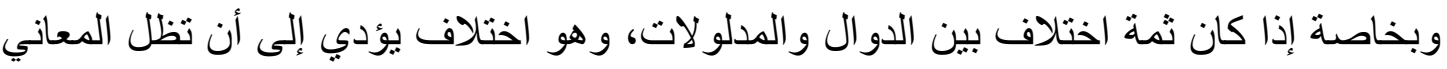
غير محددة لا تعرف الاستقرار و الثبات، ولذلك يحاول القارئ أن يستخدم مناهجه لتفكيك النص للوصول إلى المعنى الغائب و النص الغائب، وما القراءة سوى استكناه الغياب باعتبار أن الغائب

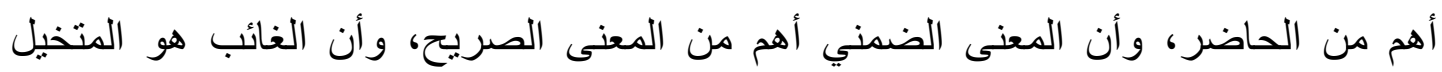

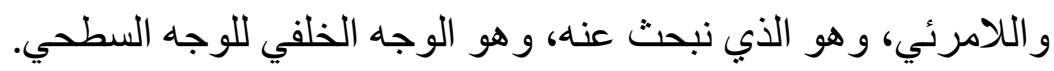

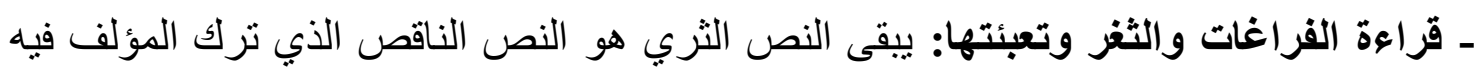

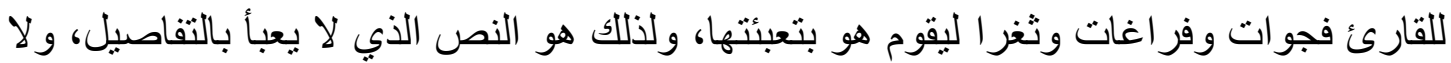
يندخل في شؤون القارئ ..هو النص المفتوح على التأويل، ويستخدم كل قارئ ثقافته وخبرته لتعبئة النقص، متقبدا بالمعنى الظاهر ليصل إلى المعنى الخفي، حيث تتم استثارة مخيلة القارئ حين يذكر النص معنى غير محدد، ودلالة الحضور تستدعي دلالة الغياب، والنص واحد، لكن القر اء كثيرون في كل زمان ومكان، و الجزء المكتوب يمنحنا المعرفة، لكن الجزء المسكوت عنه

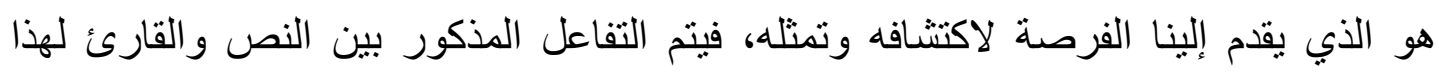

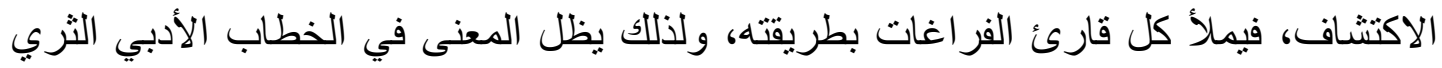
نسبيا، و هكذا يكون أيضاً المعنى الكامن في النص غير التير المعنى الظاهر فيه.

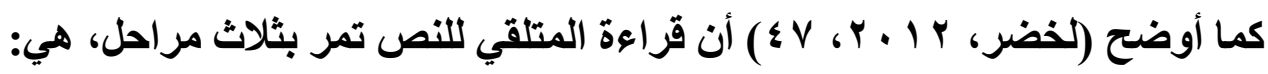

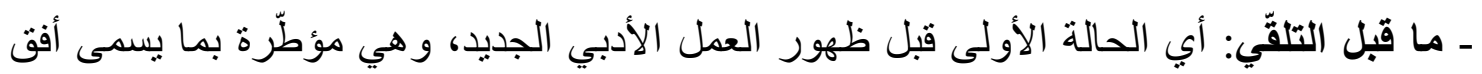
توقّع (انتظار ) الجمهور، و الذي تحكمه المعايير الفنية و الجمالية السائدة.

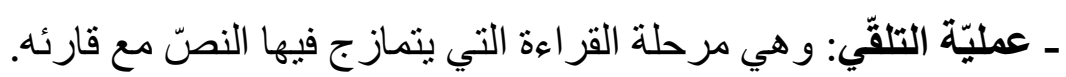
ـ ناتج التلقي: بعد دخول الحمولة المعرفيّة (أفق التوقّع)، أو منظومة المعايير السائدة، في حوار

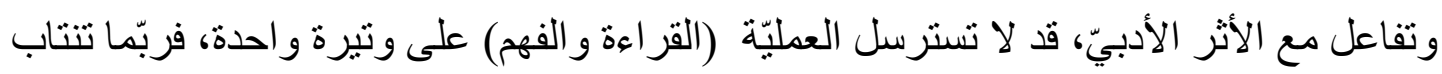
القارئ مشاعر و انفعالات مختلفة، أو ما يسمّى بكيمياء التلقيّ. 
ومهما تعددت الرؤى حيال مراحل وإجراءات تلقي العمل الأدبي نقديا، فإن هنالك ثوابت

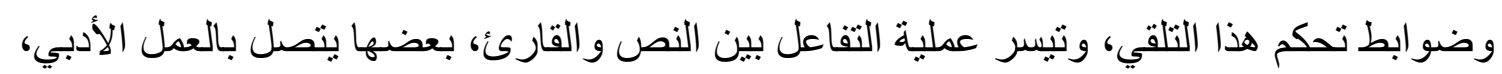
و هي: الموسوعة النصية, والبنيات اللغوية، وسياق النص، وبعضهائها الآخر يتصل بالقارئ، وهي:

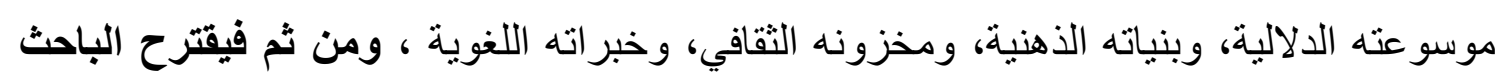
تصورا لمراحل وإجراءات تلقي العمل الأدبي نقديا، كالآتي : ـ تحديد أفق انتظار القارئ: ويتم ذلك من خلال تسجيل المتلقي لخبر اته السابقة ومعرفته الفَبْيليَّة بكل

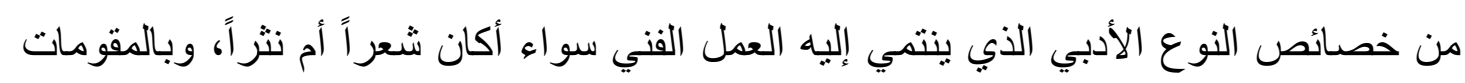
الفنية للعصر الذي ينتمي إليه الثناعر، و أيضا بأساليب المبدع ومعاييره الفنية و الجمالية و الفكرية. ـ تحديد أفق توقعات النص: ويتم ذلك من خلال فحص المتلقي لموسوعة النص أو ذخيرثه، مبتدئا

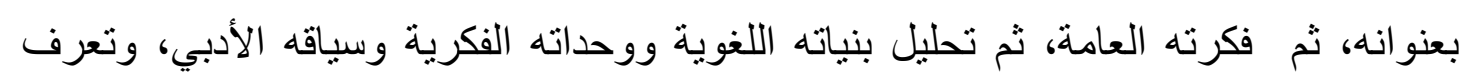

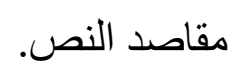

ـ قياس المسافة الجمالية للنص: وفيها يتم المقارنة بين أفق القارئ و أفق النص، وذلك من خلال

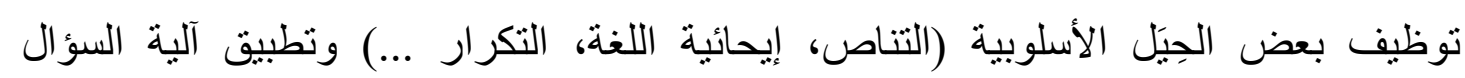
و الجواب، وأيضا عن طريق تقييم النص في ضوء ما بتضندهن من اتجاهات وقيم إنسانية واجتماعية.

ـ قراءة المعنى الغائب في النص: وذلك من خلال تحديد فجوات النص وملئها، و السياحة في فضاء

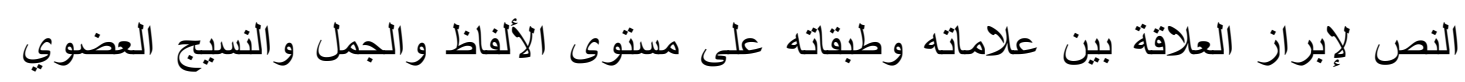
و الفكري، وتَلمّس حضور القارئ الضمني في النص، واكتشاف التر اكيب السلبية ومدى قدرنها

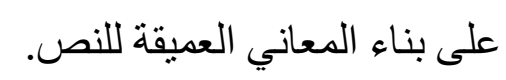
ـ إنتاج نص موازِ للنص الأصلي: و هذه المرحلة تهدف إلى محاولة استثمار العمل الأدبي في إنتاج

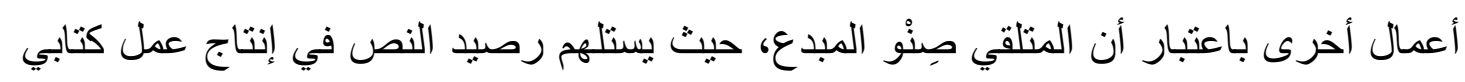

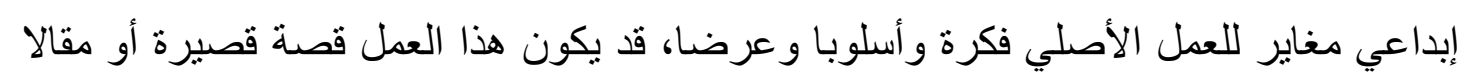

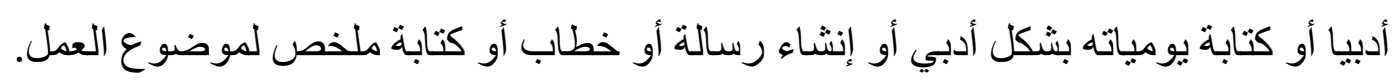
• المحور الرابع : البحوث السابقة التي تناولت نظرية التلقي في الأدب العربي ونقده :

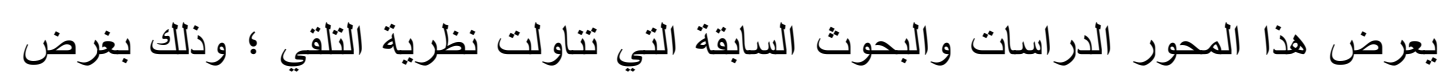
اشتقاق بعض كفايات النقد الأدبي المرتبطة بنظرية التلقي ، وتحديد بعض أسس البرنامج المقترح 
الذي تعده الدراسة الحالية لتنمية تلك الكفايات لدى طلاب شعبة اللغة العربية بكليات التربية ، وفيما يلي عرض للار اسات و البحوث السابقة ذات الصلة. أجريت العديد من الدراسات والبحوث السابقة التي تناولت نظرية التلقي في ميادين معرفية متنوعة، سواء أكان ذلك في توظيف آلياتها ومفاهيمها المعرفية في مقاربة الأدب شعره ونثره

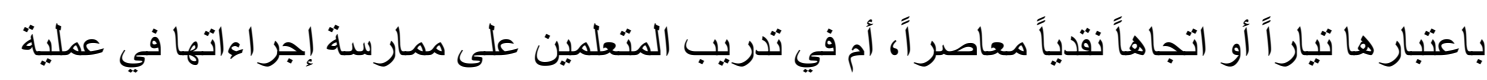

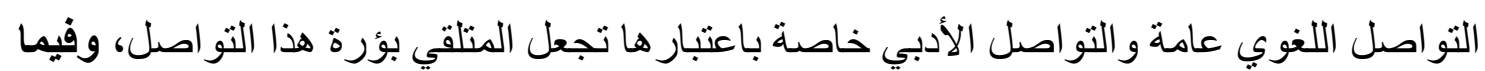
يلي عرض لذلك : قام حبيبي (بو 99 1) بدر اسة استهدفت قياس فاعلية كل من استراتيجية التعاون النصي "القارئ

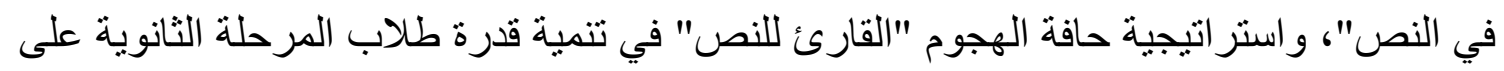

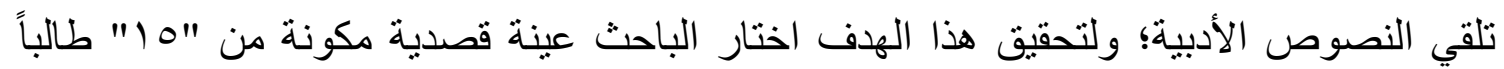
بالصف الأول، وعينة أخرى مماتلة لها بالصف الثاني من مدينة الرباط بالمملكة المغربية، وتم

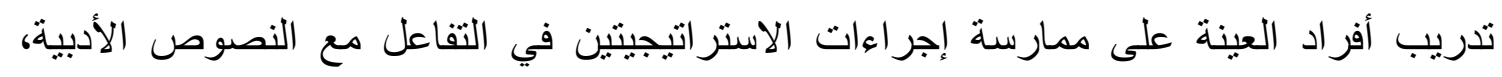

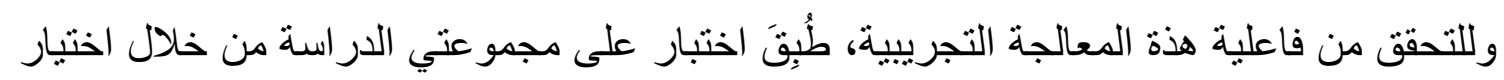

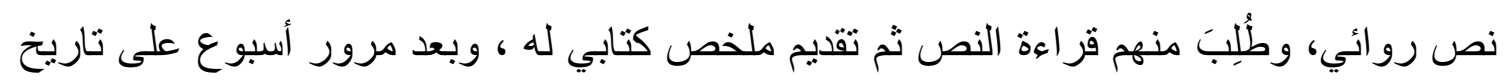

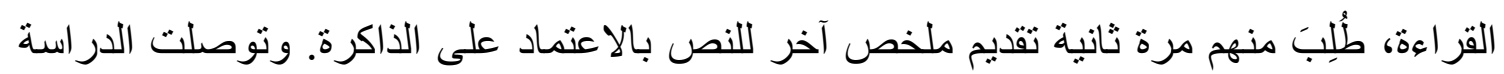

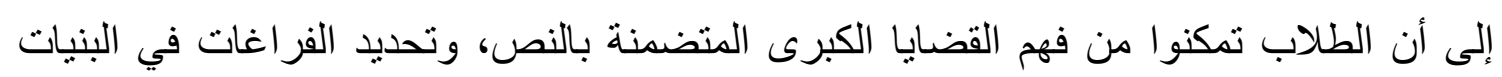
النصية، و إعادة إنتاج النص بأساليب منتو عة.

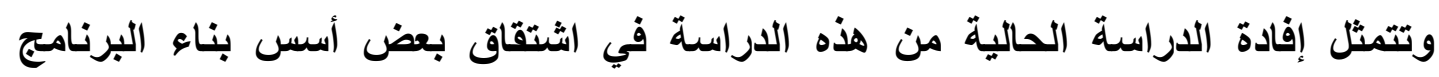

المقترح:

ـ تبصير الطلاب المعلمين بأنه في أثناء تلقي النص الأدبي لا يكتفي القارئ بتقبل المعلومات المخبر

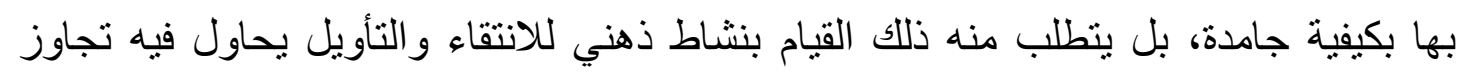

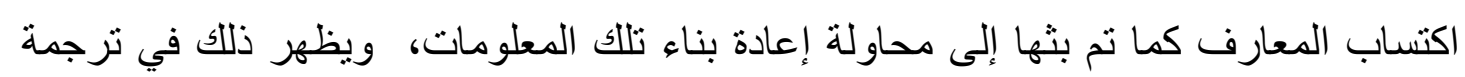

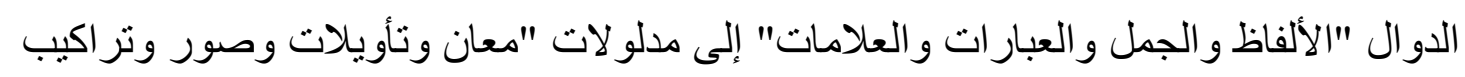
ذهنية"، وانتقاء المعلومات المهمة، وتجاوز سطح النص إلى البحث عن المسكوت عنه في نسيج

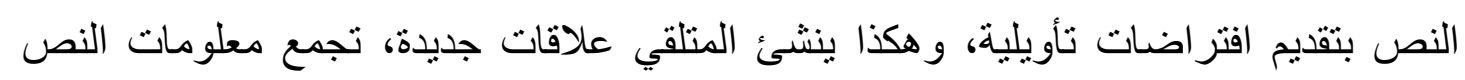


البارزة والمفيدة، وتعيد بناءها عن طريق التنظيم والاختزال، بشكل يساير العلاقات النصية

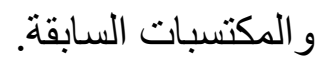

و هدفت دراسة الحمداني (ب 199 () إلى قياس مستويات تلقي القصة القصيرة لاى طلاب شعبة

اللغة العربية بكلية الآداب جامعة فاس بالمملكة المغربية؛ ولتحقيق هذا الهدف قام الباحث باستقر اء

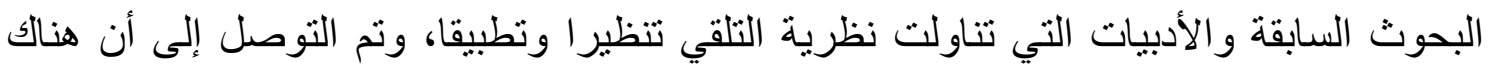
أربعة مستويات لتلقي الأدب، هي: "القراءة الحدية" ووظيفتها حصول المتلقي على المعرفة والتذوق، و "القراءة الإيديولوجية" ووظيفتها حصول المتلقي على المنفعة، و"القراءة المعرفية" ووظيفتها التحليل، و"القراءة المنهجية" ووظيفتها التأمل والمقارنة وإدراك الأبعاد، وللتحقق من ون

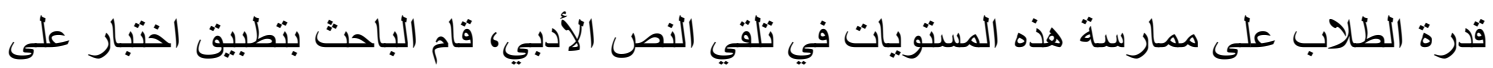

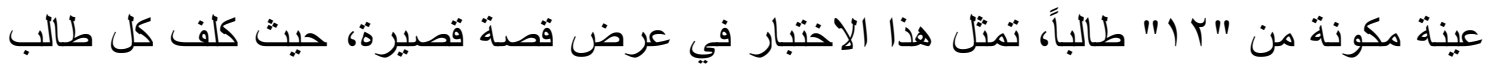

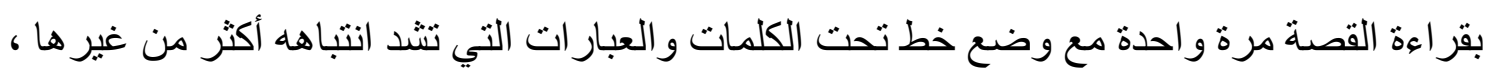

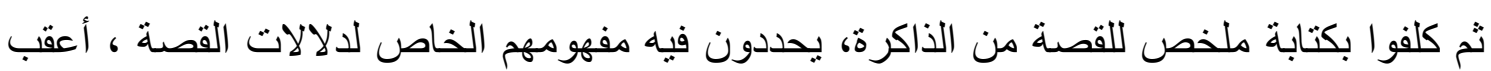

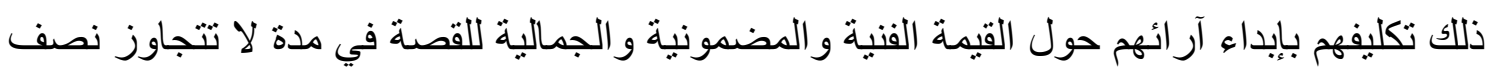

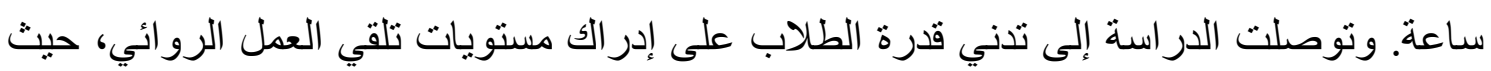

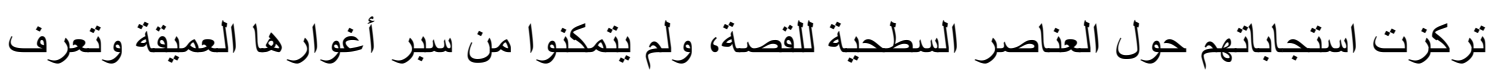

$$
\text { دلالاتها الرمزية وتحديد المسكوت عنه في بنائها. }
$$

وتتمثل إفادة الاراسة الحالية من هذه الدراسة في اشتثقاق بعض أسس بناء بناء البرنامج

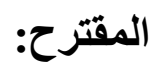

ـ تخطيط المواقف التعليمية التي توجه الطلاب المعلمين إلى أن قارئ الأدب ينظر إلى النص

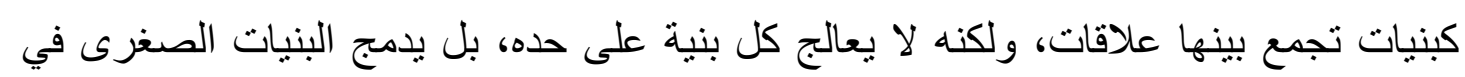

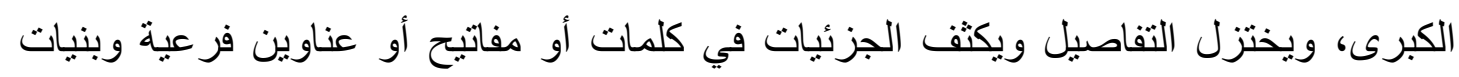

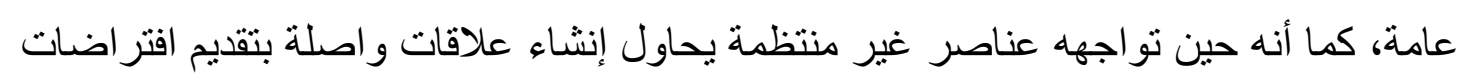

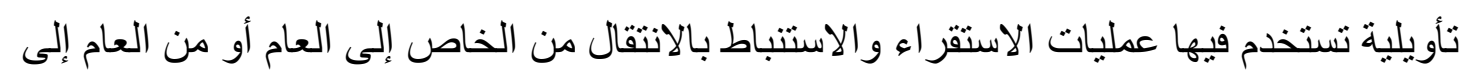

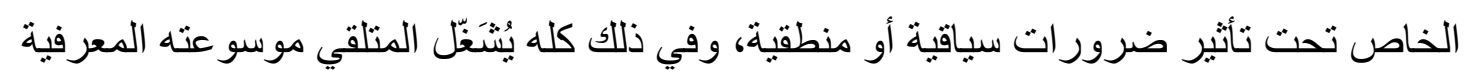
المكونة من معارف وخبر ات ومو اقف ووجهات نظر. 
كما قام حبيبي (1990) بدراسة أخرى استهدفت تعرف الاستراتيجيات التي يوظفها طلاب

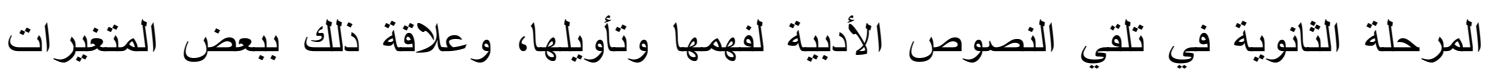

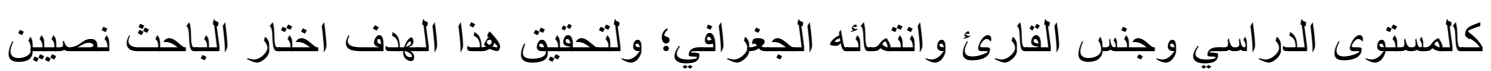

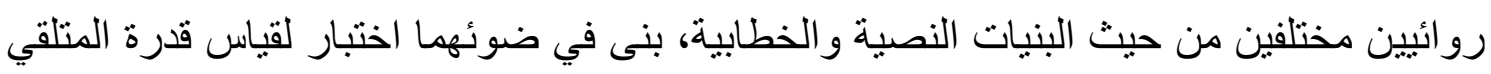
على فهم الكلمات و الجمل، وتوظيف خبر اته السابقة في استكمال ما سكت عنه النص، وتصني وتحليل العناصر الأساسية للنص، وإعادة إنتاجه عن طريق كتابة ملخصات كتابية بسترجع فيها المتلقي

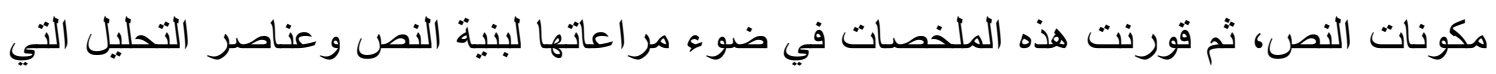

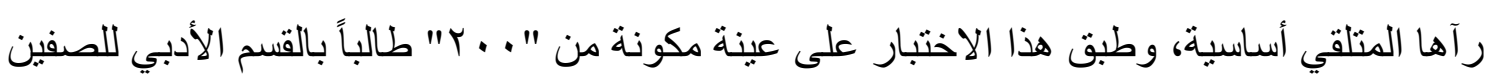

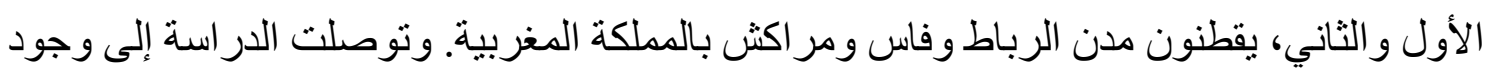

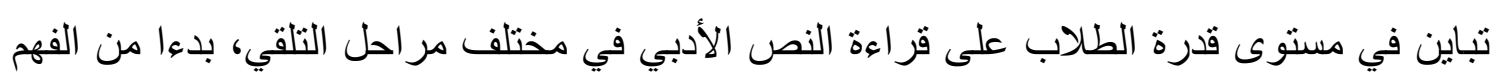

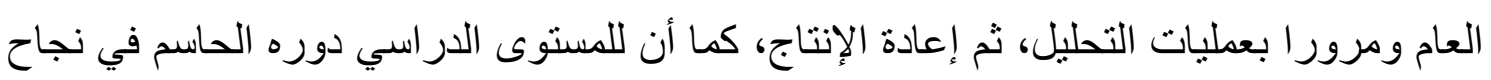

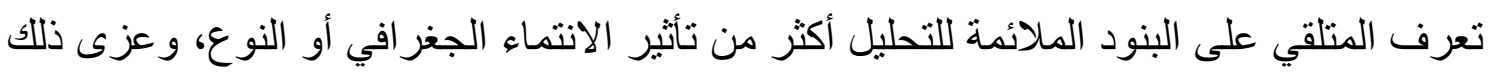

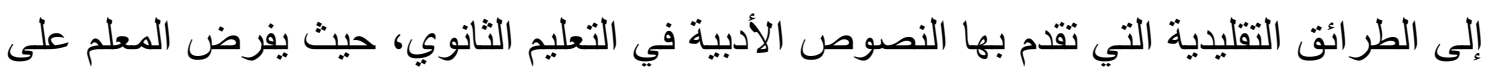

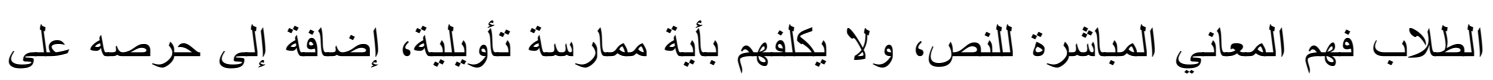
تكوين تطابق بين أفق توقع النص و أفق انتظار المتلقي.

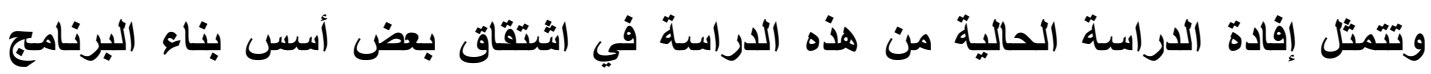

المقترح: ـ نوجيه الطلاب المعلمين إلى أن نظرية التلقي تمكن القارئ من التفاعل مع النص الأدبي، بحيث

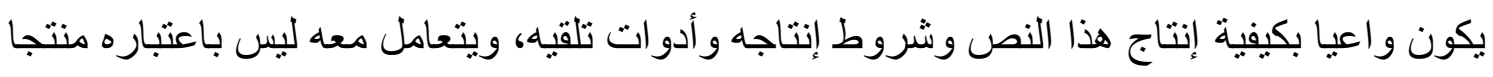
سابق التجهيز، فيعمل ذهنه ليحلل ويفسر ويناقش ويربط وينقا ويصدر حكما في فعل من أفعال

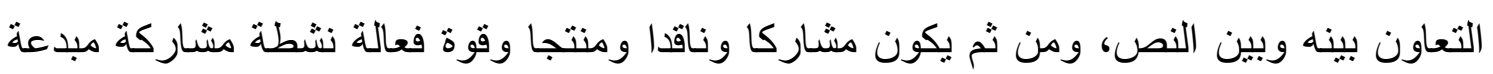
للنص. وأجرى حسن (ع . . Y) دراسة سعت إلى تعرف علاقة نظرية التلقي بالإبداع الأدبي في فن الثعر خاصة في العصر الجاهلي؛ ولتحقيق هذا الهدف استقرى الباحث الدراسات السابقة

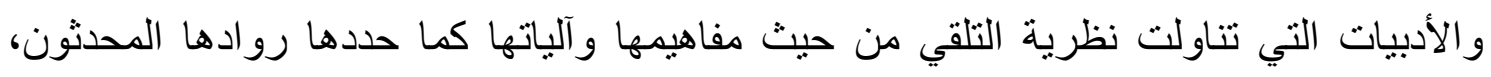
ومكانة التلقي في التراث العربي من حيث دور المتلقي الجاهلي في عملية الإبداع، وصلة المتلقي 
بالمبدع في المجتمع العربي، ودور المتلقي في تحديد موضو عات القصيدة الجاهلية، و علاقة غنائية

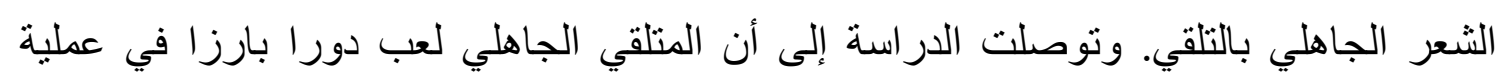

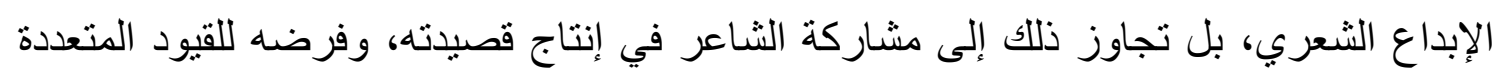

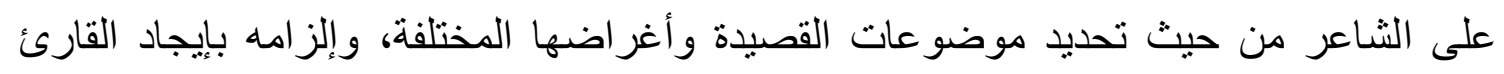
الضمني في نصد، وومر اعاة البنية الفنية "عمود الثعر مثلاً" التي تنسجم مع أفق توقعه و انتظاره.

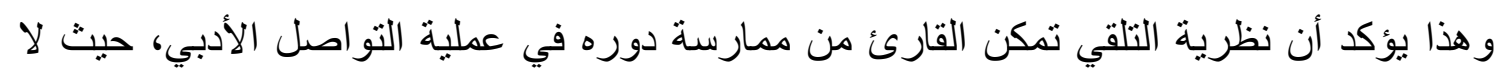

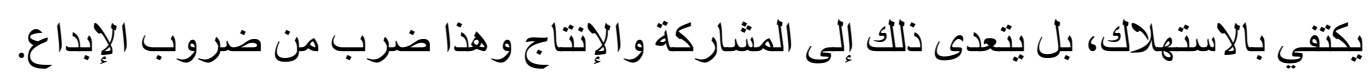

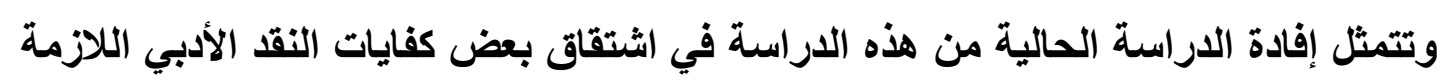

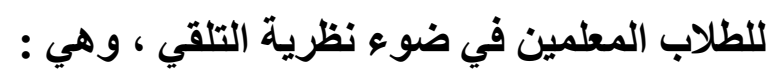
- يقارب النص الأدبي في ضو فو رؤية جديدة.

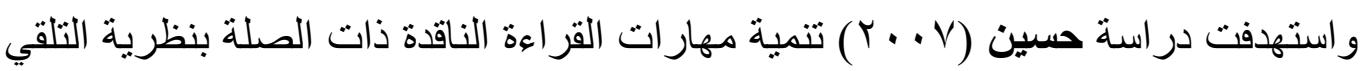

لاى التلاميذ المتفوقين بالمرحلة الإعدادية؛ ولتحقيق هذا الهدف قام الباحث بتحديد قائمة بالمهار ات دهات

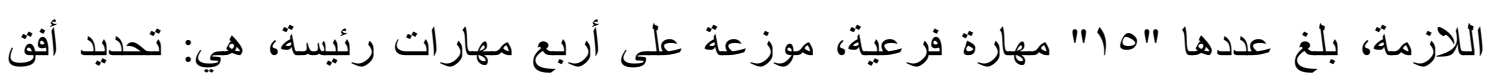

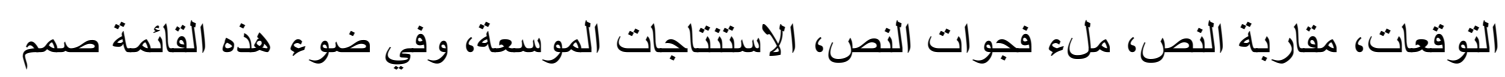

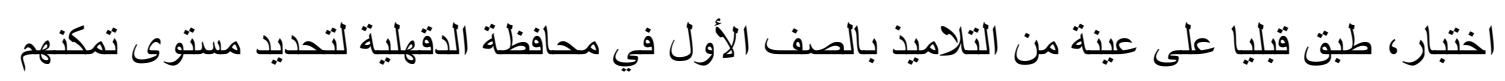

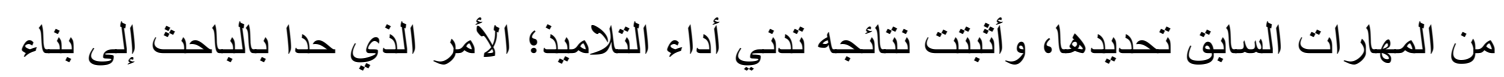

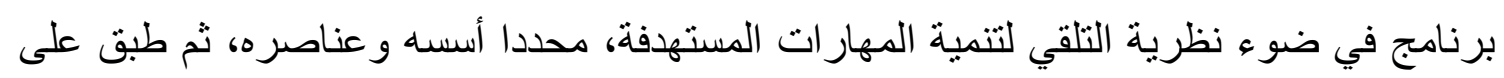

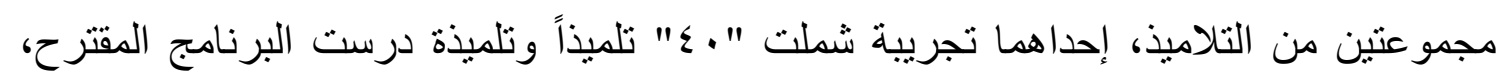
والأخرى ضابطة ضمت "،؛" تلميذا وتلميذة درست موضوعات القراءة المقررة بالطريقة

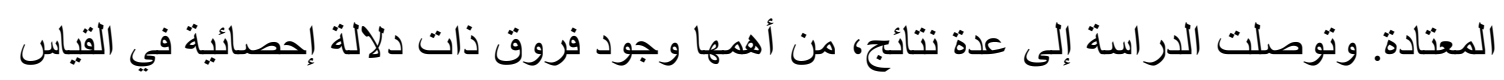

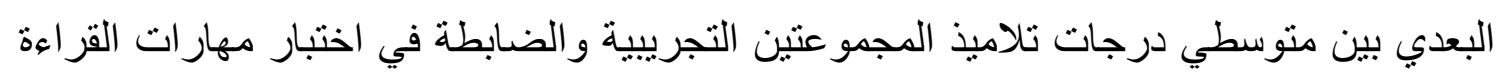

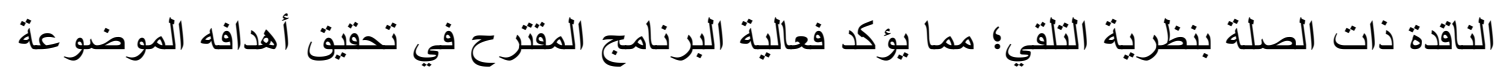
له، وبما يثبت كفاءة نظرية التلقي في تنمية مهار ات القارئ الفعال. وتتمثل إفادة الدراسة الحالية من هذه الدراسة في اشتقاق بعض كفايات النقا الأدبي اللازمة

للطلاب المعلمين في ضوء نظرية التلقي ، وهي : - يميز بين البنية السطحية والبنية العميقة في النص الأدبي. 
وقام الزيود (1 \& IV ) بدر اسة سعت إلى تأويل شعر الأديب الفلسطيني محمود درويش في ضوء نظرية التلقي؛ ولتحقيق هذا الهدف استقرئ الباحث الدراسات السابقة والأدبيات التي تناولت نظرية التلقي من حيث مرجعيتها في التراث النقدي العربي القديم، وأصولها النظرية والإجرائية عند روادها في العصر الحديث، وأهم مفاهيمها ومصطلحاتها النقدية، مثل: أفق التوقعات، و المنعطف التاريخي، و المسافة الجمالية، و القارئ الضمني، وفر اغات النص، ثم قام الباحث بتطبيق مفاهيم أفق التوقعات والمسافة الجمالية وفراغات النص على نماذج من شعر محمود درويش. وتوصلت الدراسة إلى دور التقنيات النقدية التي أفرزنها نظرية التلقي في إبراز جماليات النص

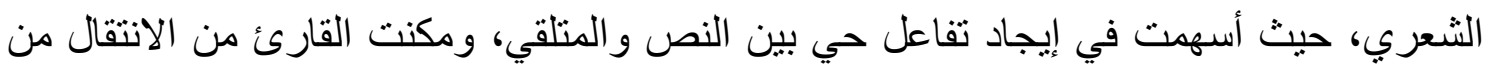
خارج النص إلى داخله محاوراً ومنتجاً ومبدعا لا مستهلكا مستمتعا. وتتمثل إفادة الدراسة الحالية من هذه الدراسة في الشتقاق بعض كفايات النقا الأدبي اللازمة

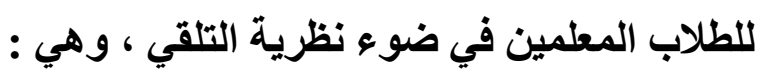
- يحدد فجوات النص الأدبي.

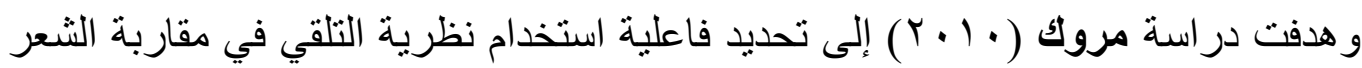
الجاهلي وإزالة الغموض العالق به واستجلاء جو انبه الفنية والجمالية وفق منظور نقدي معاصر؛ ولتحقيق هذا الهذف قامت الباحثة باستقراء الدراسات السابقة والأدبيات التي تناولت نظرية التلقي

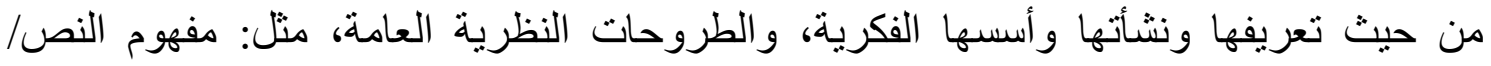
المؤلف الأدبي، مفهوم النص التخيلي/ النص التخييلي، مفهوم القارئ وعلاقته بالتاريخ الأدبي،

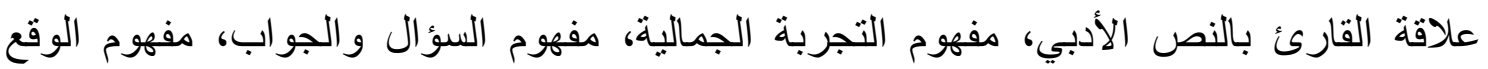
الجمالي، مفهوم الانزياح، و أيضاً الطروحات الإجرائية، متل: مكانة القارئ في نظرية التلقي، مفهوم أفق الانتظار وتجديد تاريخ الأدب، مفهوم تغيير الأفق عند ياوس، إدراك المتلقي في بناء المعنى عند إيزر، القارئ النموذجي عند إيكو ، وكذلك أسس القراءة و إجر اءاتها وثو ابتها وحدودها، ثم طبقت الباحثة الإجراءات التطبيقية لنظرية التلقي على معلقة امرئ القيس، باعتبارها تمثل نموذجاً فنياً فريداً للشعر الجاهلي، حيث تناولت المعلقة في ضوء أفق الانتظار الأدبي من حيث المتوقع واللامتوقع في ظاهرة الوقوف على الأطلال مثل: حسن الابتداء وتأثيره في المتلقي، وجدلية الأنا والآخر، و الأنا المتعالية، والتعالي النصي، وأيضاً من حيث التثكيلات الجمالية

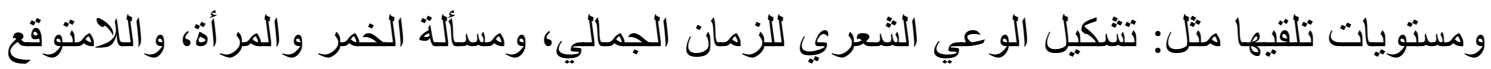

\section{7}


في الصورة الفنية، ودلالة اللون، وكذلك من حيث المهيمنات الأسلوبية في المعلقة ودلالاتها الفنية و الجمالية. وتوصلت الدراسة إلى أن نظرية التلقي تعد منهجا نقديا رصينا لها أدو اتها الدقيقة القادرة

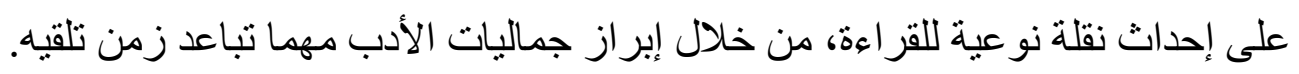
وتتمثل إفادة الدراسة الحالية من هذه الدراسة في اشتقاق بعض كض كفايات النقا الأدبي اللازمة

للطلاب المعلمين في ضوء نظرية التلقي ، وهي : - يثير بعض الأسئلة حول الجوانب الغامضة في النص.

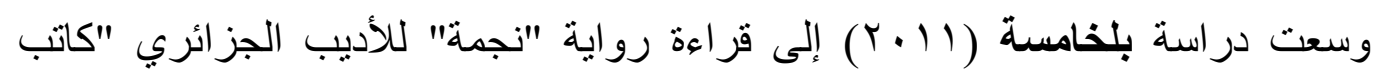
ياسين" في ضوء نظرية التلقي؛ ولتحقيق هذا الهذف راجعت الباحثة الدراسات السابقة والأدبيات التي تناولت نظرية التلقي من حيث منطلقاتها المنهجية وأسسها المعرفية ومفاهيمها المركزية لدى ولى الديه

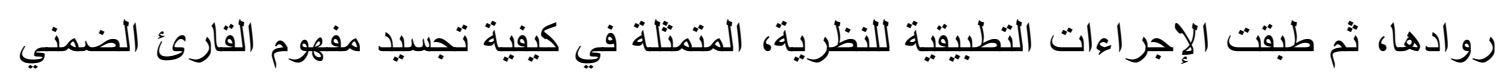

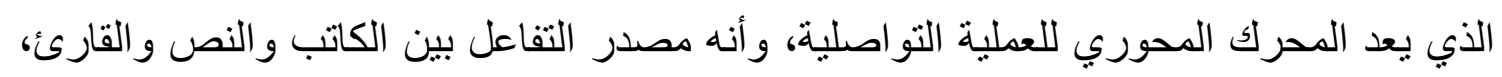

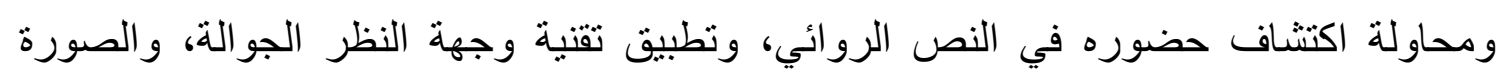
الذهنية، وتفكيك بنية الفراغات، وطاقة النفي، وكذا تفكيك الاستراتيجيات النصية وعلاقتها بقيام

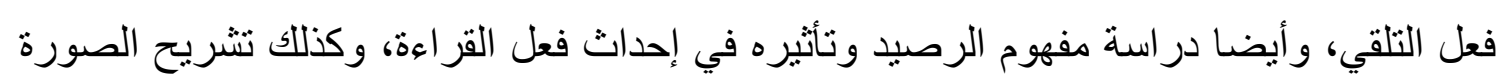
الأمامية والصورة الخلفية التي يبنى عليها الخطاب الأدبي. وتوصلت الدراسة إلى كفاءة الدنهج النقدي في ضوء نظرية التلقي في محاورة النص الروائي وكثف فر اغاته و إبراز جمالياته و إنتاج نصوص موازية له. وتتمثل إفادة الدراسة الحالية من هذه الدراسة في الثتقاق بعض كفايات النقا الأدبي اللازمة للطلاب المعلمين في ضوء نظرية التلقي ، وهي :

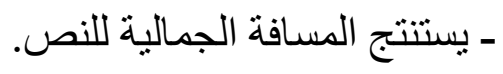

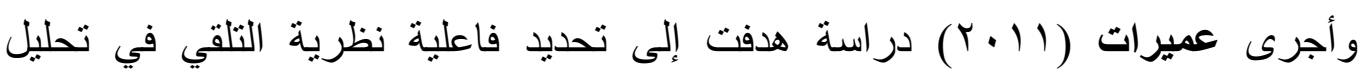

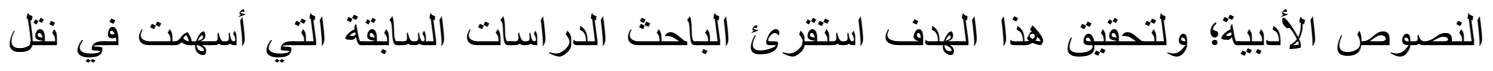

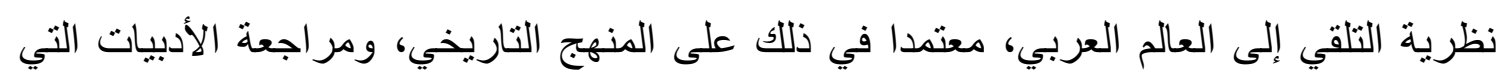
تناولت تلك النظرية النقدية، موظفا في ذلك المنهج الوصفي بهدف تحليل المنطلقات المعرفية

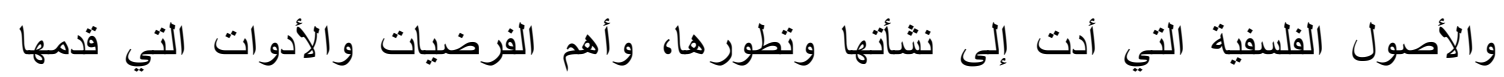
مؤسساهذه النظرية "ياوس، وإيزر"، مثل: أفق التوقع، والمسافة الجمالية، والقارئ الضمني، واني، 
والتفاعل بين القطب الفني و الجمالي وسيرورة القراءة، ثم طبق الإجر اءات التطبيقية لنظرية التلقي على نماذج من شعر المتنبي. وأوصت الدراسة بضرورة تفاعل المنظومة النقدية العربية مع نظرية التلقي باستثمار مبادئها ومفاهيمها وتطبيق فرضيات روادئ وادها من أجل ترقية الخطاب النقاي العربي المعاصر. وتتمثل إفادة الدراسة الحالية من هذه الدراسة في اشتقاق بعض كفايات النق الأدبي اللازمة للطلاب المعلمين في ضوء نظرية التلقي ، وهي :

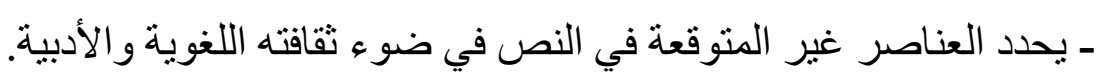

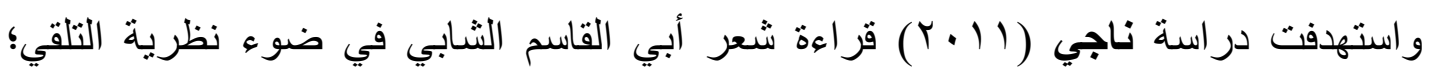

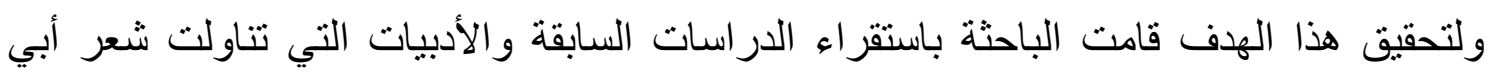
القاسم وحياته ومفارقاتها، وكذا التي تناولت نظرية التلقي من حيث دفهودها وأصوات لها في التراث

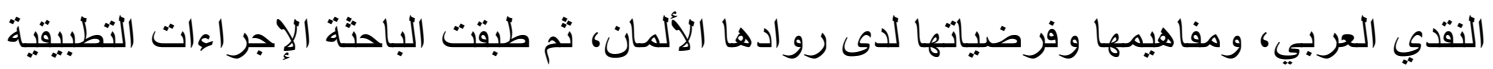
لنظرية التلقي على نماذج من شعر أبي القاسم المتضمنة في " ديو انه أغاني الحياة "، خاصة إجراء أهراء

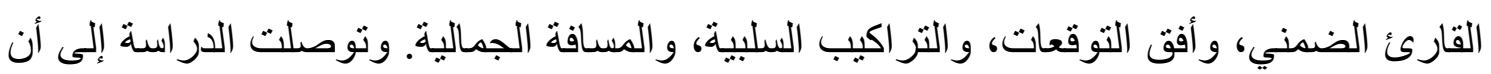

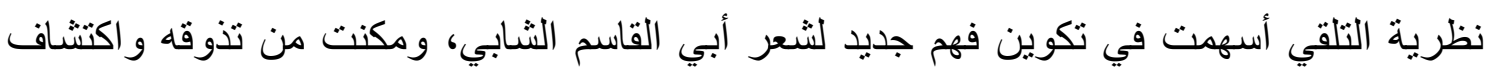

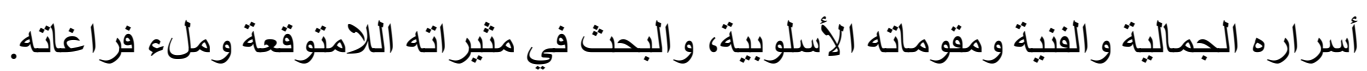
وتتمثل إفادة الدراسة الحالية من هذه الدراسة في اثتقاق بعض كفايات النقل الأدبي اللازمة

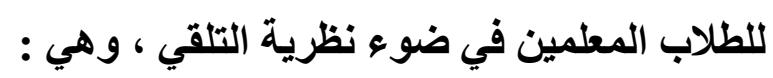
- يتو اصل مع النص وفقًا لمحمو لاته الفنبة. المحور الخامس : تحديد كفايات النقا الأدبي اللازمة لطلاب شعبة العربية بكليات التربية في ضوء نظرية التلقي : إذا كانت الدراسة الحالية تستهدف تنمية كفايات النقد الأدبي باستخدام برنامج قائم على نظرية التلقي؛ فإنه يجب تحديد الكفايات اللازمة للطلاب المعلمين باعتبار ها من الركائز الأساسية التي يعتمد عليها بناء البرنامج، وقد تم حصر تلك الكفايات التي تم التوصل إليها من خلال المصادر التالية: ـ در اسة البحوث السابقة التي تناولت نظرية التلقي في الأدب العربي ونقده. ـ در اسة البحوث السابقة التي تناولت نظرية التلقي في تدريس مهار ات اللغة العربية. 
ـ در اسة الأدبيات التي تناولت نظرية التلقي من حيث نشأتها و أهم رو ادها ومفاهيمها و أسسها. وقد نوصل الباحث إلى قائمة بكفايات النقد الأدبي في ضوء نظرية التلقي اللازمة للطلاب المعلمين، ثم قام بوضعها في صورة استبانة، بدأها بمقدمة تبين فكرة الدراسة، وما تتطلبه من بناء

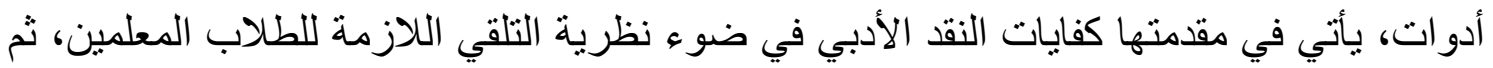
نم عرض الاستبانة على مجموعة من المحكمين المتخصصين في مجالي الأدب والنقا وطر ائق تعليم اللغة العربية ؛ لإبداء آر ائهم حول: ـ مدى ارتباط كفايات النقد الأدبي بنظرية التلقي. ـ مدى شمول الكفايات لجميع الفرضيات و الدفاهيم النقدية التي قدمها مؤسسا النظرية ومن أعقبهما من أنصار ها. ـ ـدى مناسبة الكفايات للطلاب المعلمين بشعبة اللغة العربية بكليات التربية. - إمكانية إضافة أو حذف أو تعديل ما يرونه مناسبا لهذه الدراسة. وقد أسفرت دراسة آراء السادة المحكمين عن الآتي :

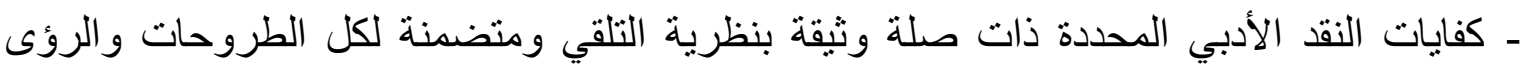
الفكرية والإجر ائية التي أسس عليها وفي ضوئها ياوس و إيز ومن تبعهما نظرية التلقي. ـ مناسبة الكفايات للطلاب المعلمين المتخصصين في اللغة العربية بكليات التربية، سواء من حيث أهداف تدريس مقررات النقد الأدبي التي يتلقونها في مرحلة الإعداد، أو من حيث تنمية ثقافتهر الأدبية و النقدية، وكذا من حيث صقل أدائهم التدريسي لمهار ات اللغة العربية. ـ إعادة صياغة كفاية "يقيس تغيير الأفق" إلى "يعلل تغيير أفق انتظاره للنص"، وقد استجاب الباحث لذلك. - حذف الكفايات الآتية : " يقارن بين المعرفة التاريخية و المعرفة الجمالية للعمل الأدبي ، يتتبع تاريخ

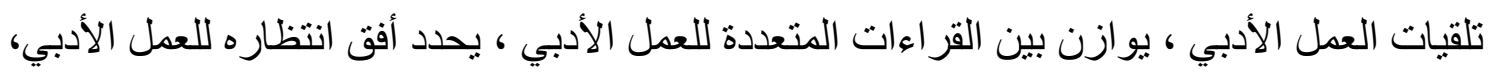

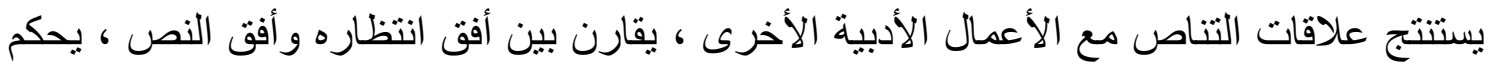
على النص الأدبي في ضوء انزياحاته الجمالية ، يحدد العناصر غير المتوقعة في النص في ضوء

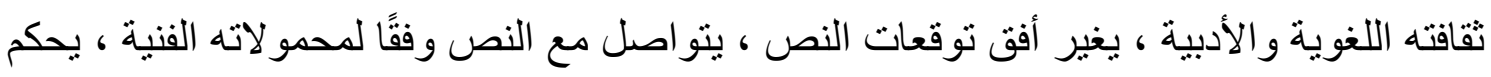

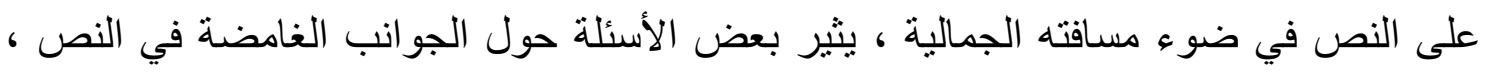

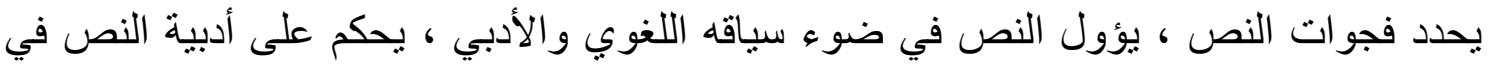

\section{9}




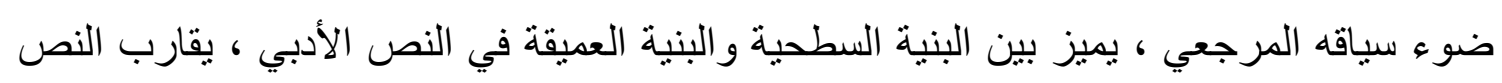

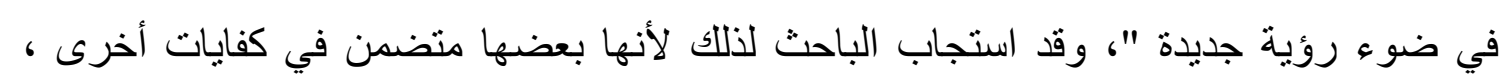
و البعض الآخر أعلى من مستوى الطالب المعلم.

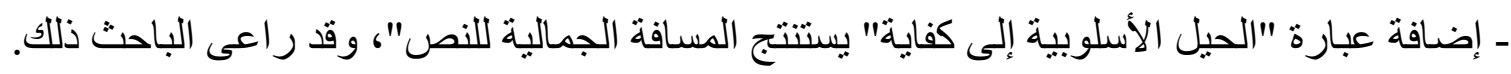

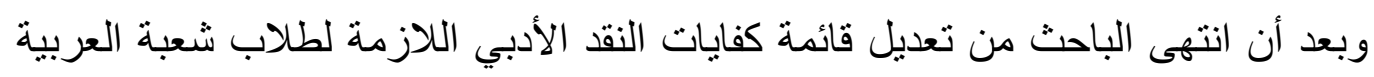

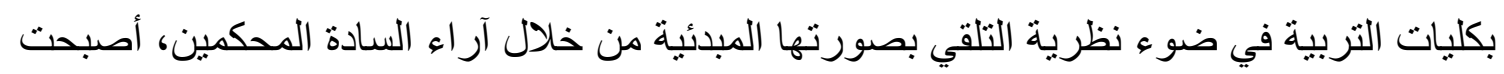

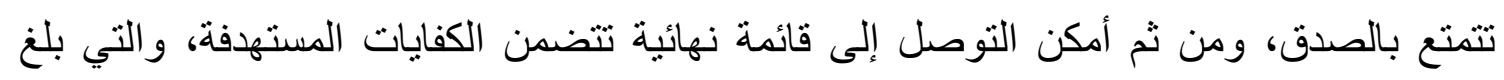
عددها " • (1" عشر كفايات(*). • المحور السادس : بناء اختبار كفايات النقا الأدبي لاى طلاب شعبة اللغة العربية بكليات التربية في ضوء نظرية التلقي: يستهدف هذا المحور تحديد مستوى تمكن الطلاب المعلمين المتخصصين في اللغة العربية من فن فئرئ

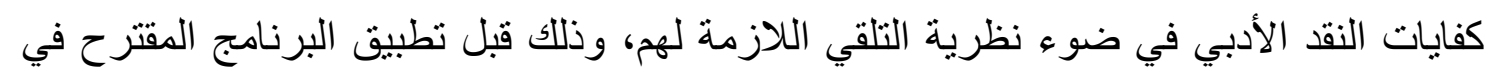
الدراسة الحالية وبعده ؛ لتعرف مدى تحقق أهداف الدراسة ؛ ولتحقيق هذا الهدف تم بناء اختبار

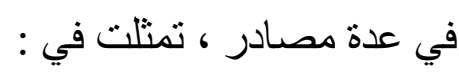

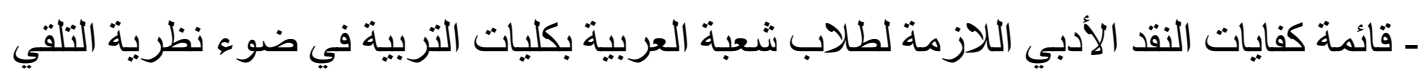

$$
\text { التي تم التوصل إليها. }
$$

ـ البحوث و الدراسات السابقة التي تناولت قياس الأدو ار المتجددة للقارئ خاصة في ضوء لنظرية

$$
\text { التلقي، وقامت بإعداد اختبار ات ومقاييس في هذا المجال، ومنها در اسة (حسين، V . . ب). }
$$

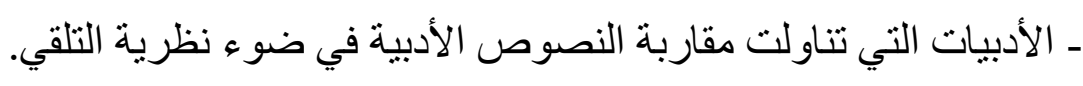

وقد تم بناء هذا الاختبار في ضوء مجموعة من الخطوات ، تضمنت الإجراءات التالية :

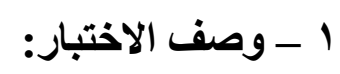

تم وضع الاختبار في صورة مبدئية، وقد تضمن الآتي:

ـ صفحة الغلاف، مكتوب عليها عنوان الاختبار ، وبيانات الباحث.

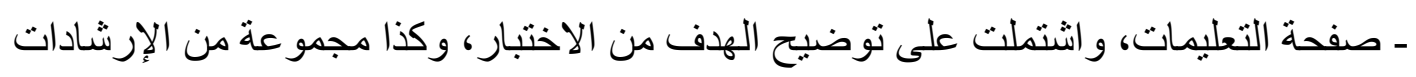
التي تبين للطالب المعلم كيقية الاستجابة لمفردات الاختبار. 
ـ محتوى الاختبار، وتضمن مفردات الاختبار، وصيغ بعض هذه المفردات في شكل اختيار من متعدد، وصيغ بعضها الآخر في صورة استجابة حرة انطلاقا من رؤية نظرية التلقي في هني

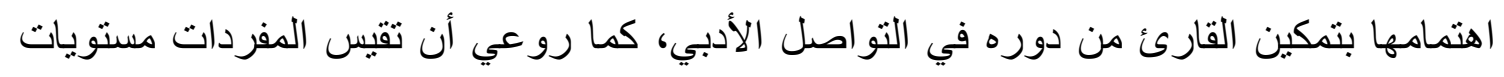
متنوعة من الجانب المعرفي، من أهمها مستوى التذكر؛ لقياس قدرة الطالب المعلم على الإلمام

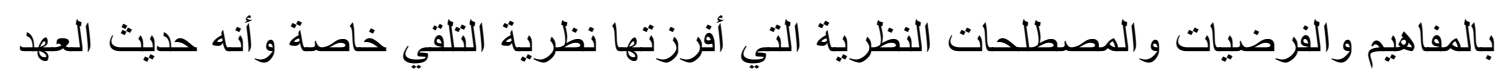

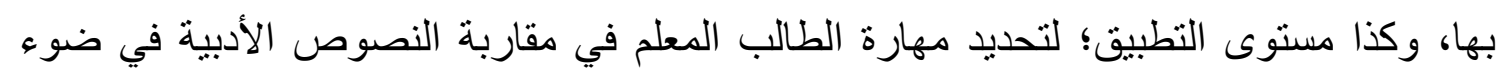
إجر اءات نظرية التلقي.

\section{r ـ تحقيق الصدق الظاهري للاختبار:}

لتحديد مدى مناسبة الاختبار للطلاب المعلمين، وكذا معرفة مدى ملاءمة الاختبار للسمات

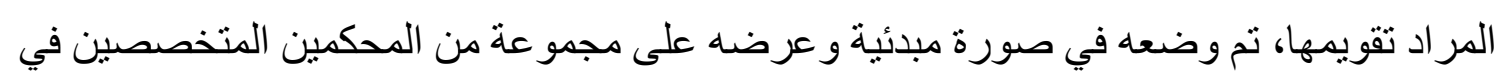

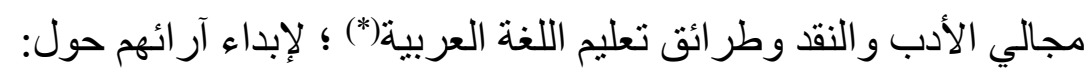
ـ مناسبة الأسئلة لقياس الكفايات المستهدفة.

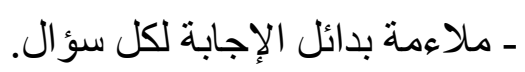

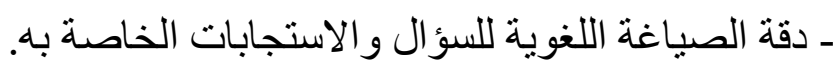
- مر اعاة الأسئلة لمستوى الطالب المعلم. - كمانه ـ كفاية الأسئلة للجو انب المعرفية المحددة. - موضوح تعليمات الاختبار. ـ صحة الإجابات المحدة لكل سؤال، والتقدير الكمي للارجات المخصصة له. وقد أسفرت دراسة آراء السادة المحكمين عن الآتي : ـ الاختبار في محتو اه يتوفر له الضبط العلمي، سو اء من حيث شمول مفرداته لكفايات النقد الأدبي

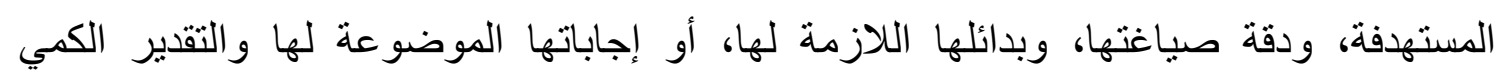
لدرجاتها، أو كفايتها للجو انب المعرفية المرتبطة بها، أو مناسبتها لمستوى المفحوصين.

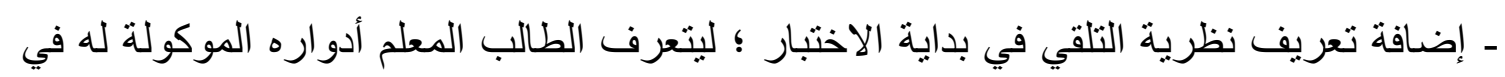

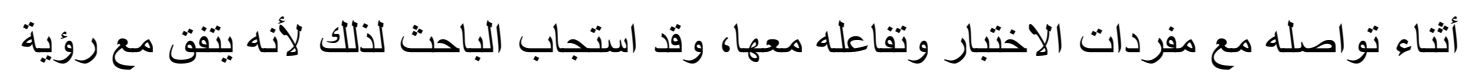
هذا التوجه النقدي المعاصر.

(*) ملحق [r] 
- حذف سؤ الين متعلقين بأهم المؤلفات و الأعمال الأدبية لقطبي نظرية التلقي، وقد استجاب الباحث لذلك لأنهما لا يضيفان جديداً للبنية المعرفية للطالب المعلم حول النظرية.

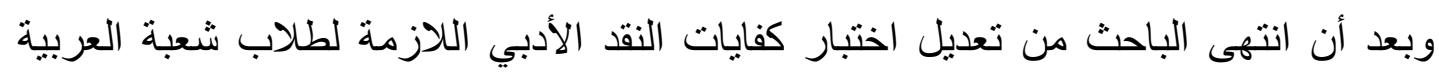

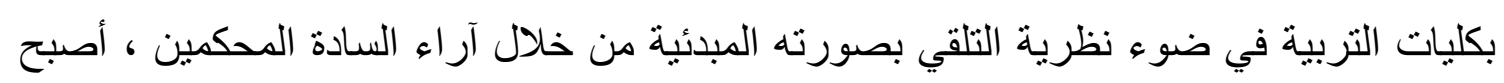

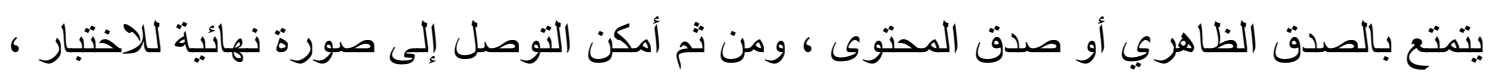

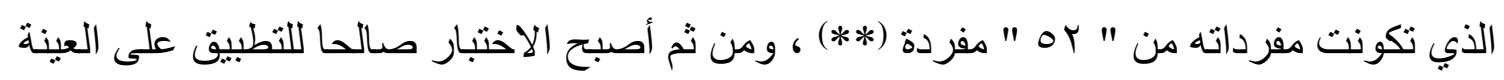
الاستطلاعية.

\section{ب - التجربة الاستطلاعية للاختبار:}

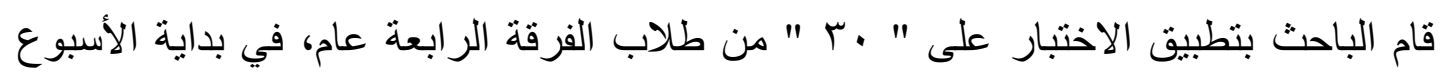

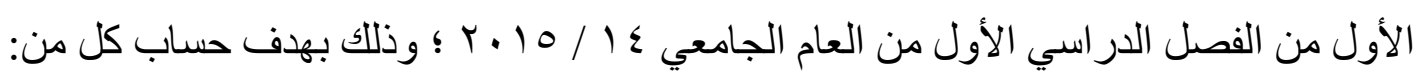

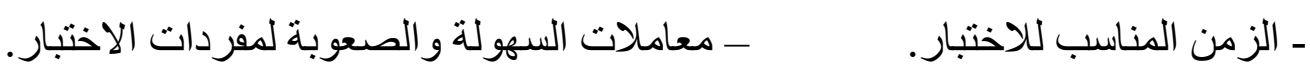
ـ معامل التمييز لمفردات الاختبار. - ثبات الاختبار. وقد أسفرت التجربة الاستطلاعية عن التائج التالية: أ - س حساب الزمن المناسب للاختبار : نم تحديد زمن تطبيق الاختبار من خلال المعادلة الآتية (أبو علام، 1991 (10، 70): الوقت الذي استغرقه أسرع طالب + الوقت الأي استغرقة أبطأ طالب الون

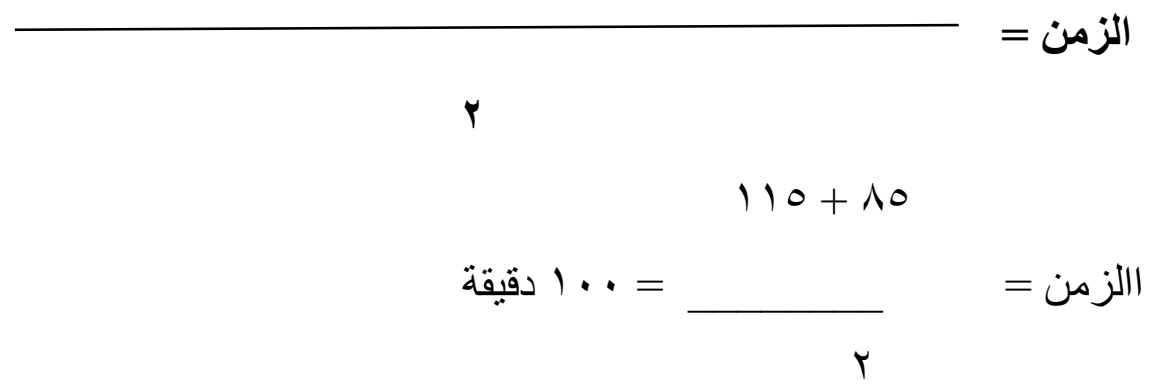

ب - حساب معاملات السهولة والصعوبة للاختبار :

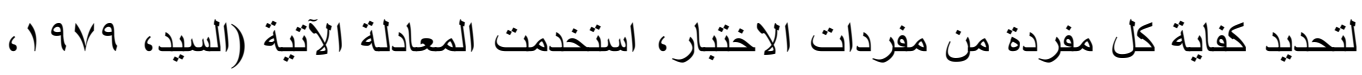




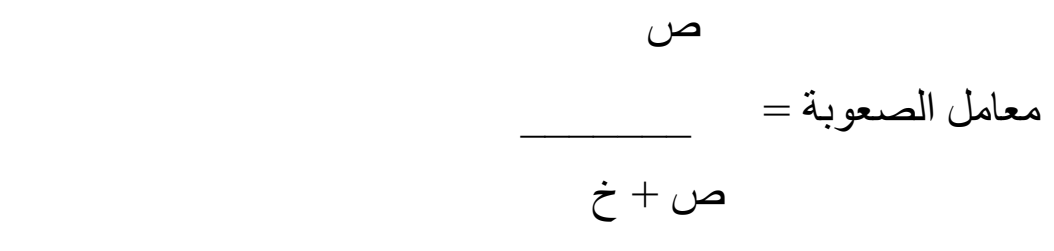

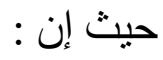

ص = عدد الطلاب المعلمين الذين أجابو ا إجابة صحيحة عن السؤال.

خ = عدد الطلاب المعلمين الذي أجابو إجابة خطأ عن السؤال.

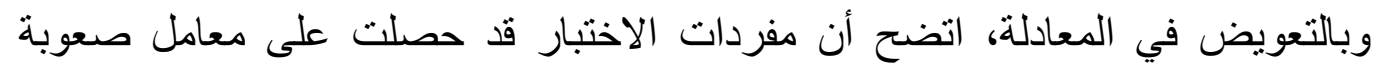

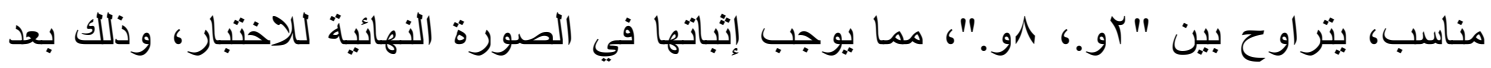

حساب معامل تمييز ها.

ج - حساب معامل التمييز لمفردات الاختبار:

لتحديد مدى قدرة كل سؤال من الأسئلة على التمييز بين الطلاب المعلمين ذوي الأداء

المرتفع و الطلاب المعلمين ذوي الأداء المنخفض، اتبعت الخطوات اتلنئ التالية:

- رتبت درجات الاختبار المصححة من أثر التخمين تنازلياً.

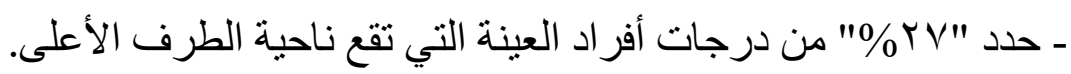

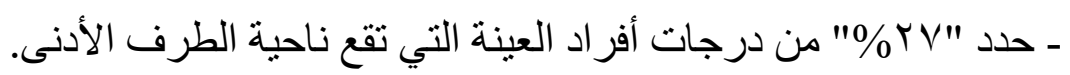

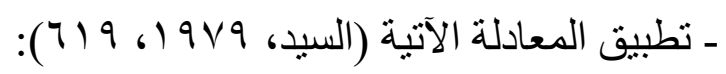

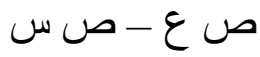
معامل تمييز المفردة = ن. ${ }^{r V}$

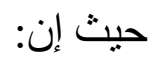
ـ ص ع = عدد إجابات السؤال الصحيح في الطرف الأعلى. ـ ص س = عدد إجابات السؤ ال الصحيح في الطرف الأدنى. - ن = عدد الأفر اد الذي أجابوا عن الاختبار. وبالتعويض في المعادلة، أمكن معرفة أن جميع دفردات الاختبار كانت على درجة تمييزية الانية عالية ومقبولة إحصائيا، حيث تراوحت بين "זو.، ؤو.". 


\section{د - د - دساب ثبات الاختبار:}

تم حساب ثبات الاختبار عن طريق تطبيق معادلة " كيودرور تثادسن " للأسئلة الموضوعية

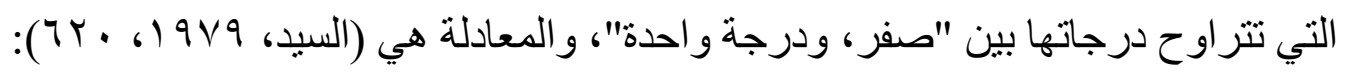

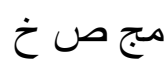

( $-1)$ ن
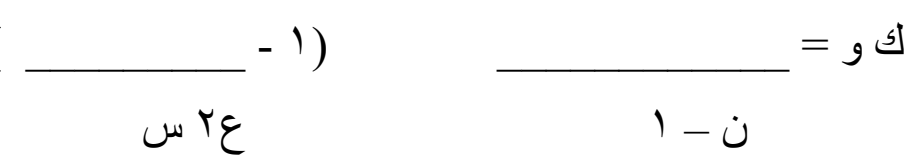

$$
\text { حيث إن: }
$$

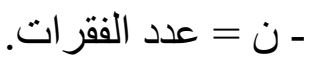

ـ مج ص خ = مجمو ع نسب الإجابات الصحيحة × نسب الإجابات الخطأ لجميع الفقرات.

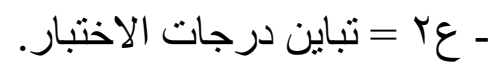
كما استخدمت معادلة " ألفا " لأسئلة المقال ؛ وذللك لاختلاف درجات درجات أسئلتها، وهي (السيد، :(7r) 6) $9 \vee 9$

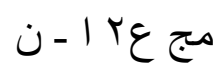

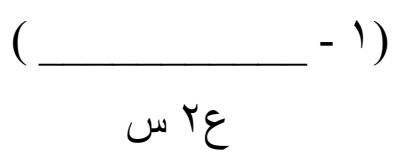

$$
\text { حيث إن: }
$$

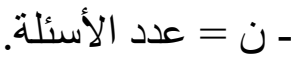

ـ مج ع = مجموع تباين الأسئلة من " (" إلى نهاية الأسئلة.

$$
\text { - ع ع س = تباين درجات الاختبار. }
$$

ومن خلال تطبيق المعادلتين السابقتين ورصد بيانات التجربة الاسنطلاعية للاختبار، وجد

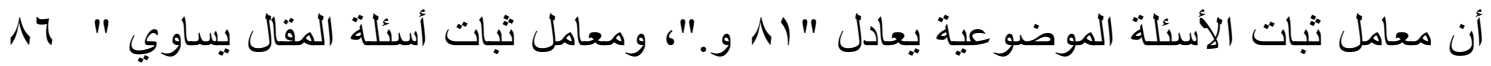

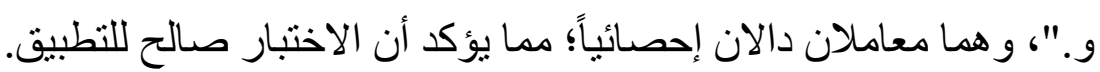

$$
\text { ؛ - إعداد نموذج تقدير درجات الاختبار: }
$$

لضمان تقييم استجابات الطلاب المعلمين على الاختبار تقييما موضو عيا أعد الباحث كراس

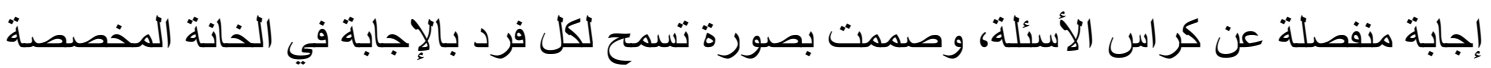


لكل سؤال(*)، كما تم وضع مفتاح الإجابة عن مفردات الاختبار، وقدرت درجات كل مفردة في ضوء ما تقيسه من معلومات، فالمفردة التي يتطلب فيها القيام باستجابة واحدة ـ كما هو في أسئلة الاختيار من متعدد - تحصل على درجة واحدة، أما أسئلة المقال، فقد وزعت الدرجات حسب حجم إجابة السؤال، ومن ثم أعطيت درجة عن كل فقرة مطلوب الإجابة عنها(**). وقد تم توزيع الاختبار على الأبعاد أو الكفايات المقيسة، و الجدول التالي يوضح ذللك : جدول ( 1 ) توزيع مفردات الاختبار على الكفايات المقيسة

\begin{tabular}{|c|c|c|c|c|c|c|c|c|}
\hline \multirow{3}{*}{ الالازبة } & \multicolumn{6}{|c|}{ نمـــــــالأسئلة } & \multirow{3}{*}{ كفايات التقد الأدبي في ضوء } & \multirow{3}{*}{ p } \\
\hline & \multicolumn{3}{|c|}{ مقالية } & \multicolumn{3}{|c|}{ موضوعية } & & \\
\hline & درجاتها & عددها & أرقامها & درجاتها & عددها & أرقامها & & \\
\hline 7 & - & - & - & 7 & 7 & 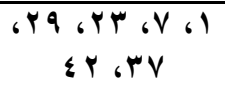 & يحدد أفق توقعات العمل الأدبي & 1 \\
\hline 7 & $r$ & $\bar{Y}$ & rism. & $r$ & $r$ & 176968 & يقارن بين أفق انتظاره وأقق النص & $r$ \\
\hline 7 & $r$ & $r$ & YI. Y. & $\varepsilon$ & $\varepsilon$ & $11,1 Y 6 Y_{6} Y_{0}$ & يعلل تغييز أفق انتظاره للنص & $r$ \\
\hline 7 & $r$ & $r$ & $\begin{array}{l}11 \\
115\end{array}$ & $r$ & $r$ & Tr, & يستنتج المسافة الجمالية للنصل بعض الحيل الحيل & $\varepsilon$ \\
\hline$\varepsilon$ & $r$ & 1 & $\varepsilon V$ & 1 & $T$ & IV & بطبق آلية السؤال والجواب في النصأئي & 0 \\
\hline$r$ & - & - & - & $r$ & $r$ & $0.6 \leq \Gamma$ & يقيم التص في ضوهات وقيم اجتماعية يتضنه & 7 \\
\hline $1 \cdot$ & $r$ & 1 & $\varepsilon \varepsilon$ & V & $\mathrm{V}$ & $\begin{array}{l}\text { h } \\
\text { h }\end{array}$ & يملأ فجوات النص لإعادة بنائه & $\mathrm{V}$ \\
\hline 1. & $r$ & 1 & $\varepsilon 7$ & $\mathrm{~V}$ & $\bar{v}$ & 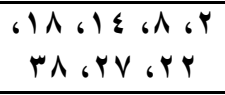 & يستنتج علامـات القارئ الضمني & $\Lambda$ \\
\hline$\Lambda$ & 1 & 1 & Or & $\mathrm{V}$ & $\mathrm{V}$ & $\begin{array}{c}6 \varepsilon \cdot 610,4 \\
6 \leqslant 96 \leqslant \wedge, \leqslant 1 \\
01 \\
\end{array}$ & 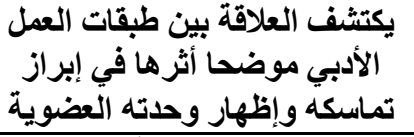 & 9 \\
\hline 0 & $\varepsilon$ & 1 & $\leqslant 0$ & 1 & 1 & 7 & محدر الثراكيب السلبية في النص تكوين صوره & 1 . \\
\hline Tr & Yr & 11 & & $\$ 1$ & $\sum 1$ & & المجموع & \\
\hline
\end{tabular}


• المحور السابع : بناء البرنامج القائم على نظرية التلقي لتنمية كفايات النقد الأدبي لاى طلاب شعبة اللغة العربية بكليات التربية:

يستهذف هذا المحور تحديد أسس بناء البرنامج المقترح في الدراسة الحالية ، وكذا تحديد

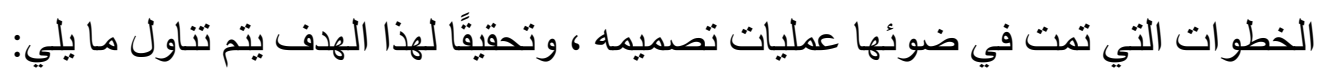

أولًا : تحديد أسس بناء البرنامج :

انطلق البرنامج المقترح في الدر اسة الحالية من عدة أسس، اشتقت من خلال ما تم عرضه من

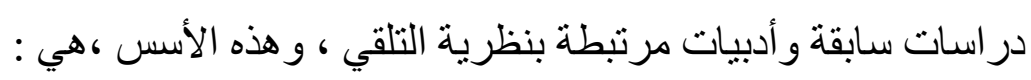

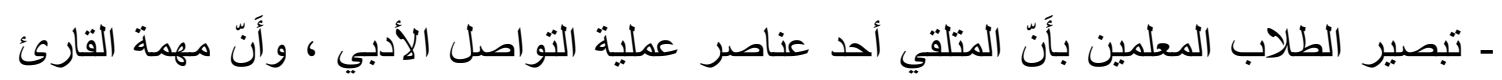
و المتلقي لا تقتصر على مجرد المشاركة ، بل إنها تتجاوز ذلك إلى البحث ما وراء الصيه الصياغة الصدئ

ومتابعة خيوطهاهو التفاعل بينه وبين بنينه، و إخر اج ما هو منضمن في النص إلى دائرة الضود الضها.

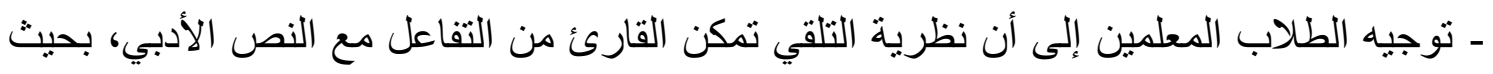

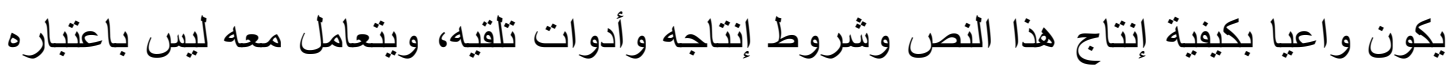
منتجا سابق التجهيز، فيعمل ذهنه ليحلل ويفسر ويناقش ويربط وينقا ويصدر حكما في فعل من ون

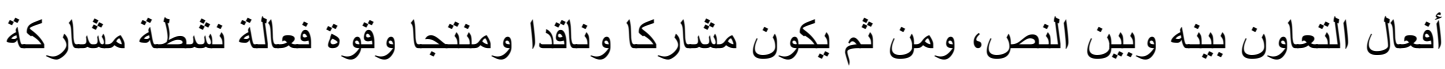
مبدعة للنص.

ـ تبصير الطلاب المعلمين بأن قارئ النص الأدبي ليس مجرد مستقبل سلبي، بل هو متلق منتج،

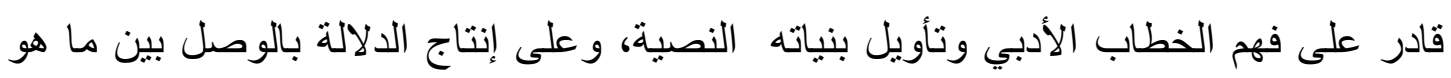
مو افق وما هو مفارق في هذا الخطاب، بين الصريح و الضمني، بين المبنين وما هو قابل للبنية.

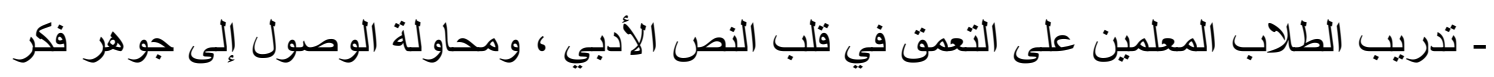

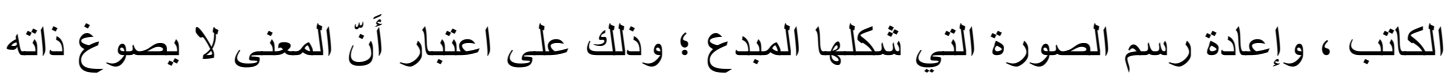

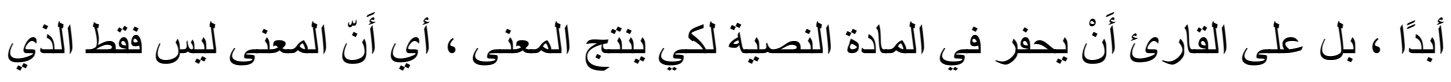

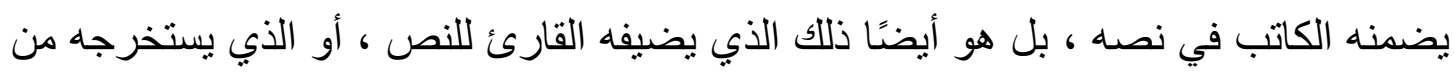
النص.

- إن النص الأدبي الكامل بانسجامه و اتساقه أكثر قدرة على جعل المتلقي يتفاعل معه فهما وتحليلا و إنتاجا؛ ولذا فقد حرصت الدراسة الحالية على تقديم نصوص أدبية متكاملة تمكن الطلاب 
المعلمين من تكوين رؤية كلية عن أفكار ها ومحتو اها وبما يسمح لهم من نقدها في ضوء نظرية

التلقي.

ـ تبصير الطلاب المعلمين بأنه في أثناء تلقي النص الأدبي لا يكتفي القارئ بتقبل المعلومات المخبر

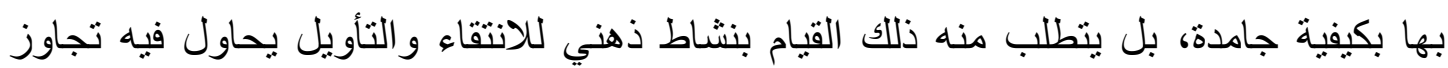

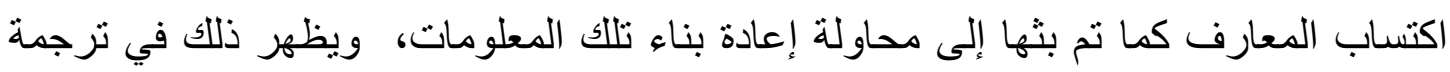

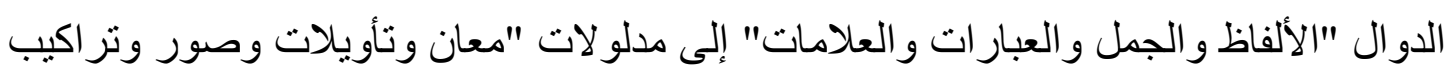
ذهنية"، و انتقاء المعلومات المهمة، وتجاوز سطح النص إلى البحث عن المسكوت عنه في نسيج

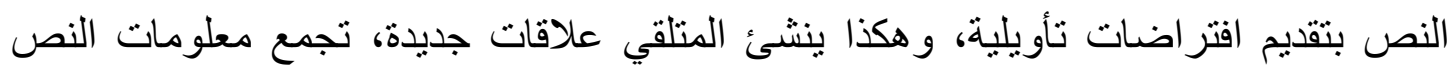

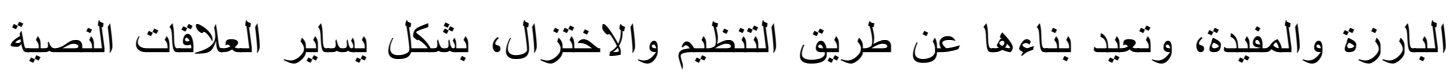

$$
\text { و المكتسبات السابقة. }
$$

ـ تخطيط المواقف التعليمية التي توجه الطلاب المعلمين إلى أن قارئ الأدب ينظر إلى النص

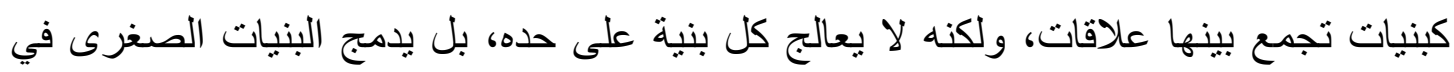

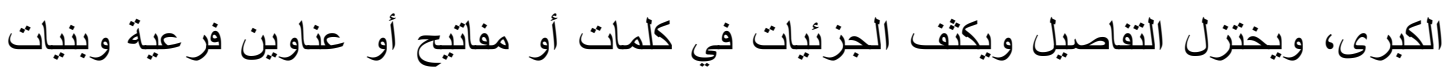

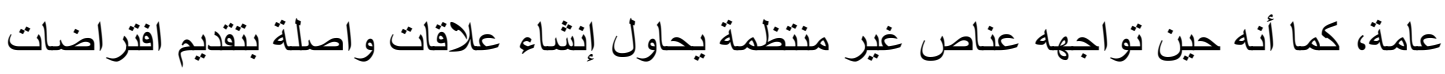

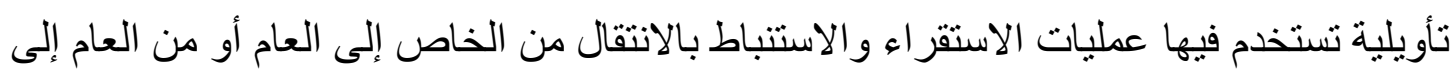

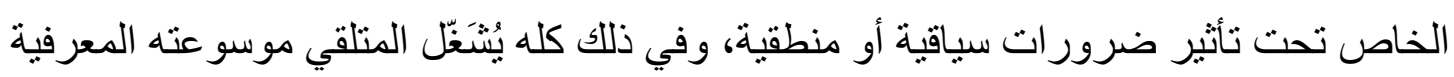
المكونة من معارف وخبر ات ومو اقف ووجهات نظر. ـ تبصير الطلاب المعلمين بأن للمعارف السابقة للمتلقي دورا في الوصل بين القارئ والمقروء، فئه فالنص الأدبي له مرجعيته الخاصة به وسجله أو ذخيرته، وكلما اتسعت رقعة هذا السجل

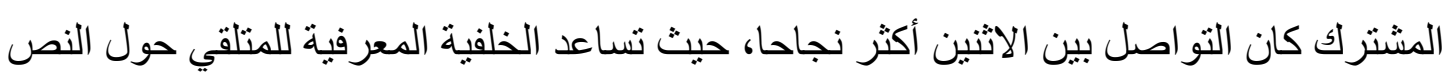

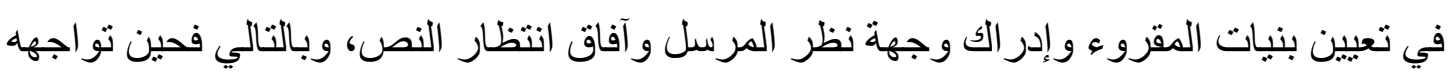

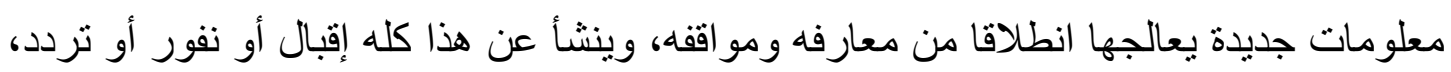
و هذا ما عبر عنه "ياوس" بالمسافة الجمالية.

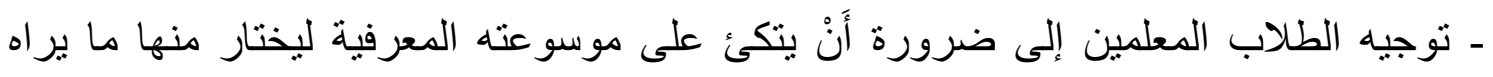

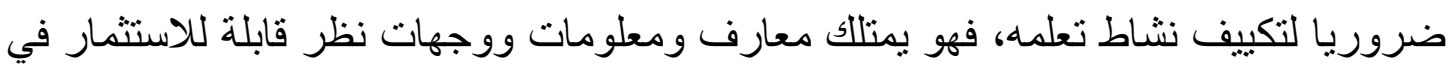

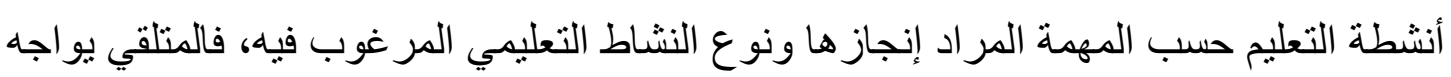


النص انطلاقا من مؤشرات نصية "اسم المبدع - جنس النوع الأدبي...." وكذلك تحديد مؤشر ات

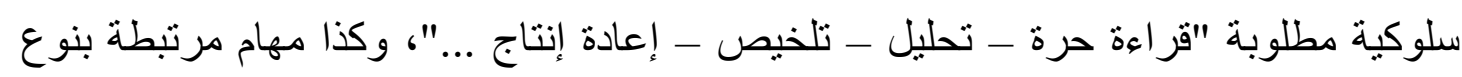

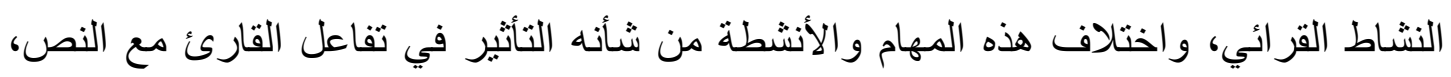

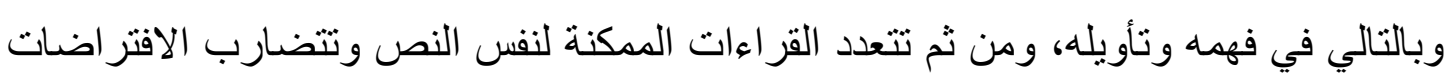
التأويلية وتتداخل آفاق الانتظار. ـ مر اعاة أن الاهتمام بالقراءة والقارئ قاسم مشترك بين أصحاب النقد الأدبي وعلماء النفس

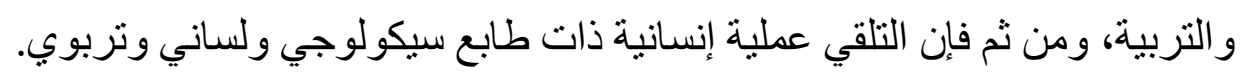

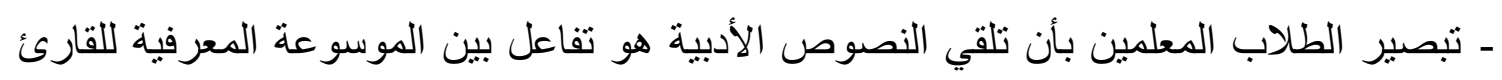

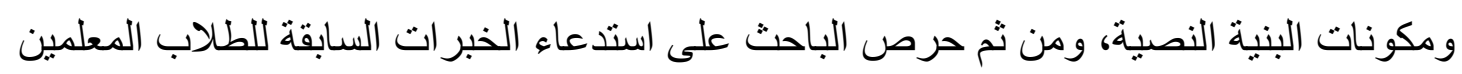

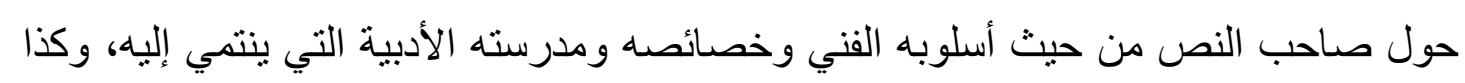
خصائص النوع الأدبي المقدم لهم من حيث سماته ومقوماته و عناصره.

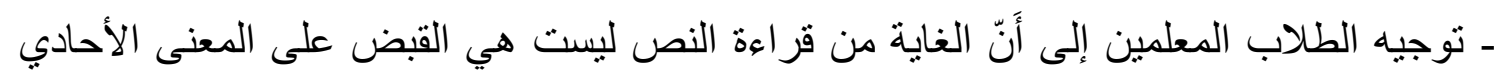

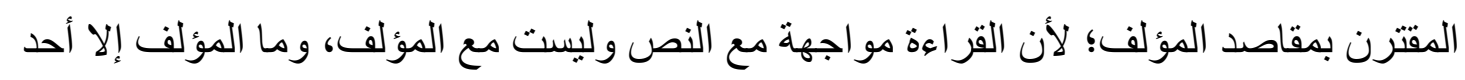

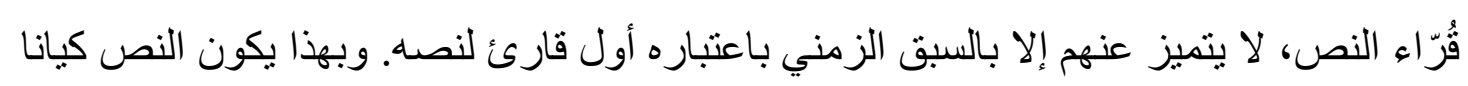

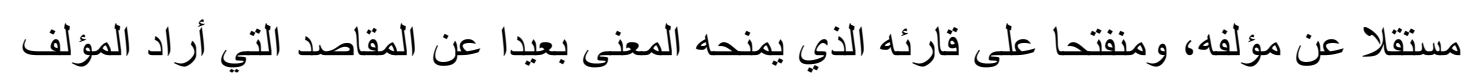

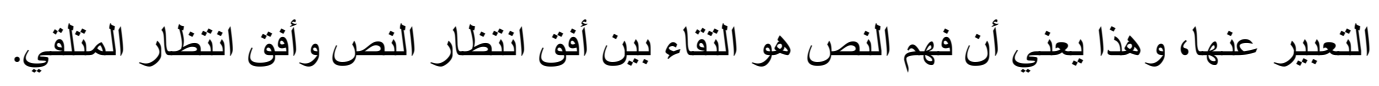

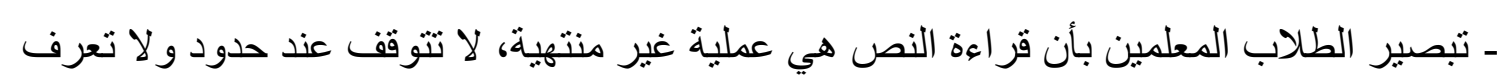

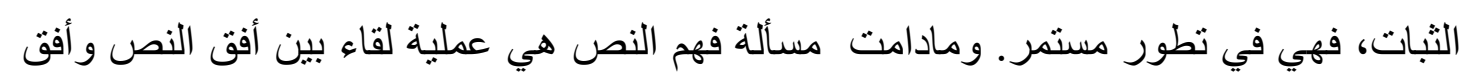
قارئه، فإن كل تحول في أفق انتظار المتلقي من شأنه أن ينتج إمكانية جديدة للتركيب و والامتز اجي،

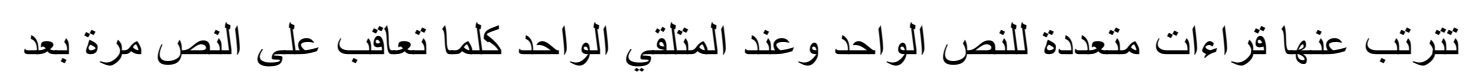

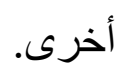

ـ تبصير الطلاب المعلمين بأن تلقي النص الأدبي لا يتحقق إلا بوجود قارئ يمتلك كفايات نقدية تمكنه من تعيين البنيات النصية وتأويلها.

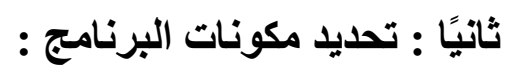

اعتمد الباحث في بناء البرنامج المقترح في الدراسة الحالية البادية على الدصادر التالية:

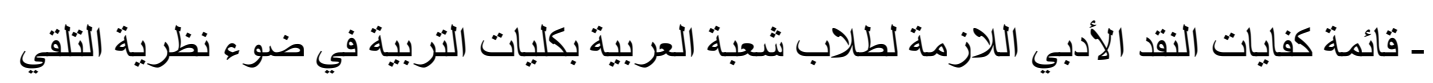


التي تم التوصل إليها.

ـ الأدبيات التي تناولت مقاربة النصوص الأدبية في ضوه إنهاء نظرية التلقي.

ـ أهداف تدريس النقد الأدبي للطلاب المعلمين شعبة اللغة العربية بكليات التربية.

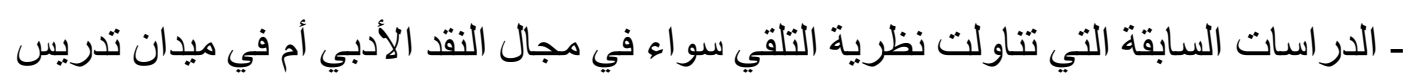
مهار ات اللغة العربية.

وقد تضمن البرنامج المقترح في الدراسة الحالية العناصر والمكونات التالية :

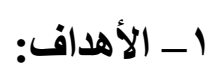

سعى البرنامج الحالي إلى تحقيق هدف رئيس تحدد في تنمية كفايات النقد الأدبي لاى الدى

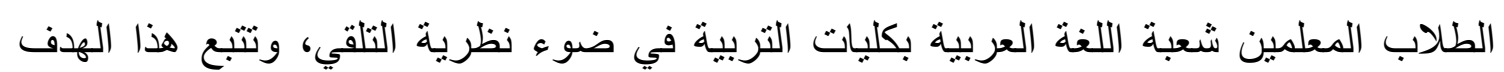
أهداف عامة أخرى، تمثلت في تنمية قدرة الطالب المعلم على الآتي: - ـ تحديد أفق توقعات العمل الأدبي.

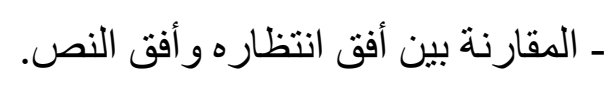
ـ ت تعليل تغيير أفق انتظاره للنص. ـ استنتاج المسافة الجمالية للنص من خلال بعض الحيل الأسلوبية، مثل: التناص، و إيحائية اللغة، و التكر ار.

ـ تطبيق آلية السؤال و الجواب في بناء معاني النص وتأويلها. ـ تقبيم النص في ضو ء ما يتضمنه من اتجاهات وقيم اجتماعية و إنسانية. ـ ملء فجو ات النص لإعادة بنائه و إنتاج معناه.

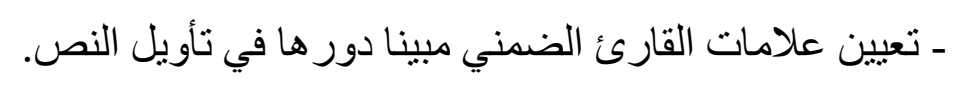

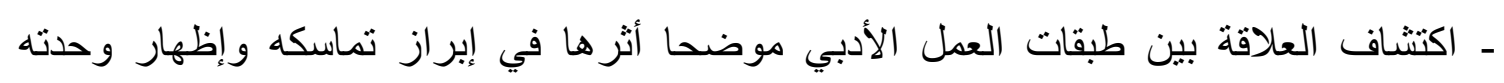
العضوية.

- إبر از التر اكيب السلبية في النص محددا أثر ها في تكوين صوره العميقة. ـ التمييز بين البنية السطحية و البنية العميقة في النص الأدبي.

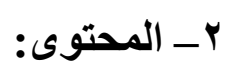

في ضوء الأهداف العامة السابقة للبرنامج المقترح اختير المحتوى الدراسي للبرنامج، وروعي أن يتضمن المحتوى مادة علمية صحيحة، وأن يكون في مستوى الطلاب المعلمين، ويسهل تعلمه الاهن

\section{ipq}


ذانيا، ويغطي الكفايات المحدة، ويسمح بإتاحة الفرص للمندرب للمناقثة، و الاستعانة بالقراءات الخارجية، والقيام بالأنشطة التعليمية المصاحبة التي تدعم عملية التعلم.

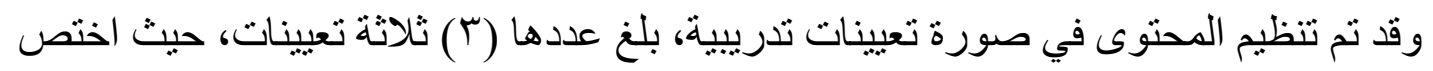

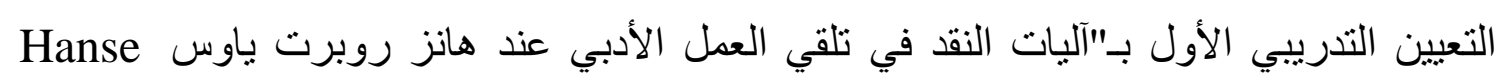

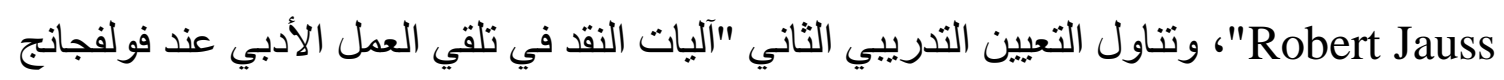
إيزر Wolfgang Iser" " ، وخصص التعيين التدريبي الثالث لـ"مر احل و إجراءات نقد العمل فئل الأدبي في ضوء نظرية التلقي".

وروعي أن يتضمن كل تعيين تدريبي العناصر التالية : ـ أهداف التعيين: وهي أهداف تعليمية إجر ائية ينوقع تحقيقها عقب اكتساب الطالب المعلم الكفايات المتضمنة بالتعبين. ـ محتوى التعيين: ويتضمن الخبرات التي تسعى إلى إكساب المندرب الكفايات الواردة به، كما أعقب كل جزء من أجز اء المحتوى أنشطة تعليمية يقوم بها المتدرب لدئ لدعم ما تم تعلمه.

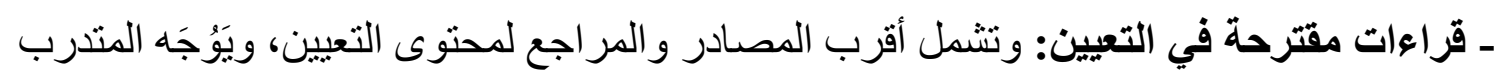
إليها لإثر اء أفقه المعرفي حوله. ـ تقويم التعيين: ويتضمن أسئلة تستهلف قياس أثر دراسة التعيين في إكساب الطالب المعلم

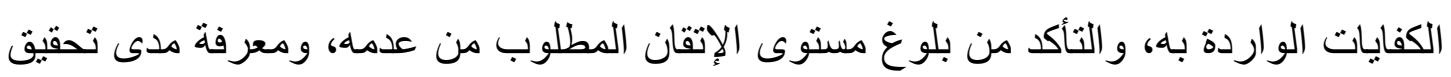

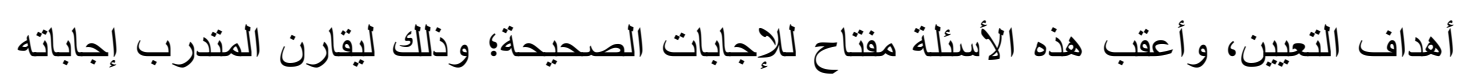

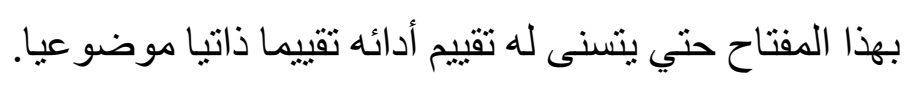

واعتبر كل تعيين من تعيينات البرنامج وحدة تعلم متصلة منفصلة في الوقت نفسه، فهو يعد بلدي

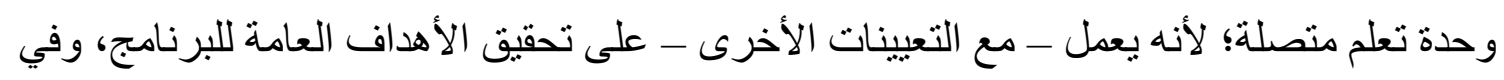

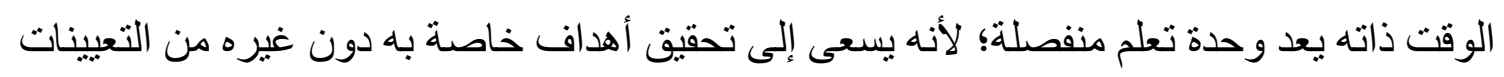

$$
\begin{aligned}
& \text { إذا ما درسه الطالب المعلم دراسة مستقلة. } \\
& \text { r-_طرائق التدريس: }
\end{aligned}
$$

اعتمد البرنامج الحالي على توظيف عدة طر ائق واستر اتيجيات تدريسية تناسب طبيعة الكفايات المستهدف تنميتها باستخدام هذا البرنامج لدى الطلاب المعلمين شعبة اللغة العربية بكليات التربية، وفيما يلي عرض لهذه الطر ائق و الاستر اتيجيات: 


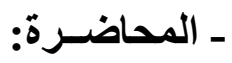

وهي عبارة عن عملية اتصال بين فرد ومجموعة، يقوم فيها المحاضر بتقديم معلومات

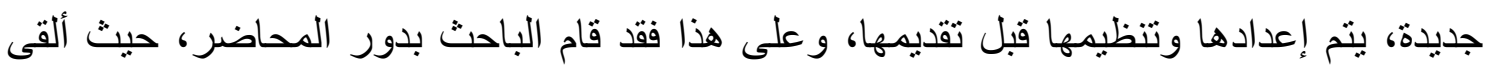
بعض المحاضرات الخاصة بالطروحات الفكرية والفلسفية لنظرية التلقي، ومنطلقاتها المعرفية و أصولها المنهجية، ومفاهيمها المركزية لدى روادها، و التي تتضمنها الكفايات الواردة بالتعينين التدربيين الأول و الثاني، على الطلاب المعلمين عينة الدر اسة. وقد راعى الباحث حين توظيف هذه الطريقة حُسْن عرض وتقديم المادة العلمية بأسلوب يناسب مستوى المندربين واحتياجاتهم، وتبسيط الدصطلحات و المفاهيم النقدية التي طرحتها نظرية التلقي، وإدادهم بدليل للدحاضرة، يتناول النقاط الأساسية المطروحة، والمشكلات التي سيتم إثارتها، و القراءات والمصادر التي يمكن الرجوع إليها-مع توفير ها- حتى يتهيأ الطلاب المعلمون للإنصات للمحاضرة، و إعداد النقاط التي قد تثير استفسار اتهم، كما تم تخصيص وقت عقب الانتهاء

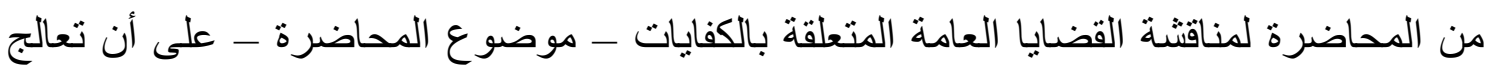
المشكلات والأفكار الفر عية في حلقات المناقشة، وكذا الإجابة عن بعض تساؤلات أفر اد العينة مثل: الفرق بين نظرية التلقي والمناهج النقدية السابقة، وعلاقتها بتلك المناهج، ومميزات النظرية، ومكانتها في الفكر النقدي المعاصر، ودور ها في تدريس مهار ات اللغة العربية وتعليم مناهج الأدب و النقد في مر احل التعليم وتعلمها.

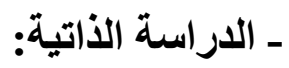
وتلائم هذه الطريقة التعيينات التدريبية التي تمثل المحتوى الدراسي للبرنامج الحالي أو

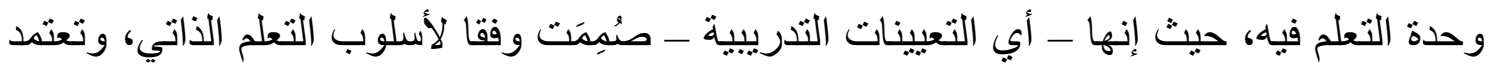
در استها - في أجز اء كبيرة منها - على التعلم الذاتي، وقد نم توظيف أسلوب الدراسة الذاتية عن طريق توجيه الطلاب المعلمين إلى الرجوع إلى بعض الكتب و المر اجع والدراسات السابقة التي

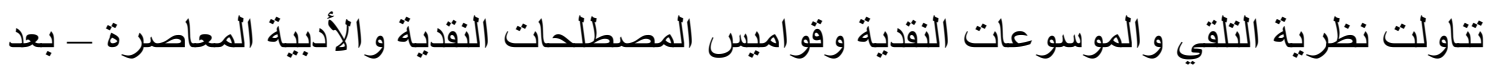
توفير بعضها - بهدف جمع المعلومات المرتبطة بتعلم كفاية نقدية معينة من الكفايات المتضمنة في التعيين، ثم كتابتها في تقرير بذللك، وعرضه على الباحث، كما تم توجيه الطلاب إلى تنفيذ الأنشطة التي تعقب تعلم كل عنصر من عناصر التعيينات التدريبية وذلك لإكمال فهمه و إتمام در استها. 


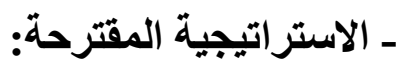

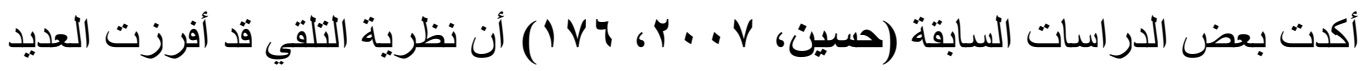

من الاستراتيجيات التدريسية الهناسبة لآلياتها النقدية، منها: استراتيجية الإسهاب أو التفصيل، لهيك،

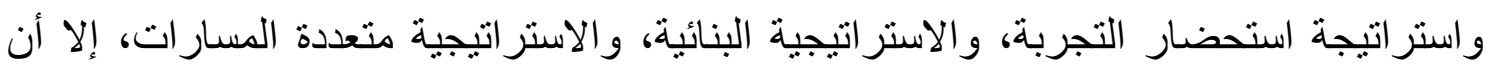
الباحث اقترح استراتيجية تتضمن مجموعة من الخطوات والإجراءات تم ذكرها في الإطار

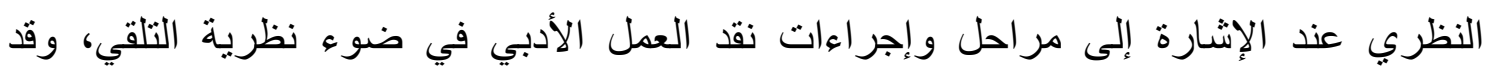
استخدمت هذه الاستر اتيجية المقترحة في تدريس التعيين التدريبي الثالث.

\section{؛ - الأنشطة والوسائل التعليمية:}

لمساعدة الطلاب المعلمين على تحقيق أهداف البرنامج الحالي و إتقان ما تضدئه من كفايات

؛ فقد استخدمت الأنشطة و الوسائل التالية:

ـ كُنَيَب البرنامج " التعيينات التندريبية ". ـ الإجابة عن الأسئلة التي تلي كل عنصان لتصر من عناصر التعيين. - المو اقع الأدبية الإلكترونية.

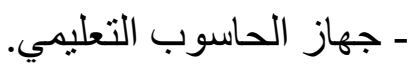
- إعداد قو ائم بمصادر القر اءات الخارجية.

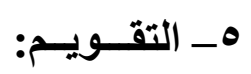

لقياس قدرة البرنامج الحالي على تتمية كفايات النقد الأدبي في ضوء نظرية التلقي لدى طلاب شعبة اللغة العربية بكلبات التربية، وتحديد مدى تمكن هؤلاء الطلاب من هذه الكفايات

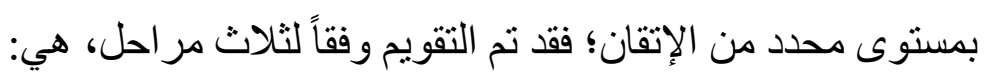
ـ التقويم القبلي: ويكون قبل الانطلاق في دراسة البرنامج، ويهدف هذا النوع من التقويم إلى هنى

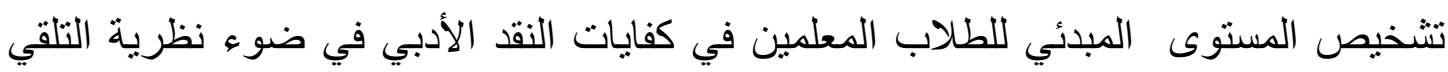

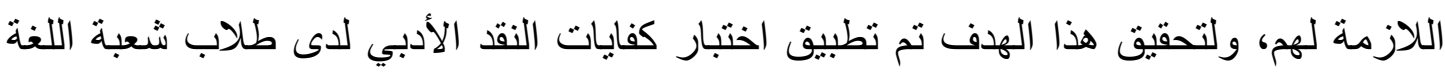
العربية بكليات التربية في ضوء نظرية التلقي السابق التوصل إليه.

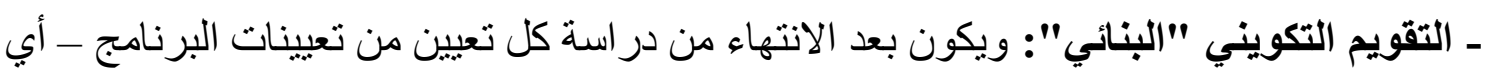

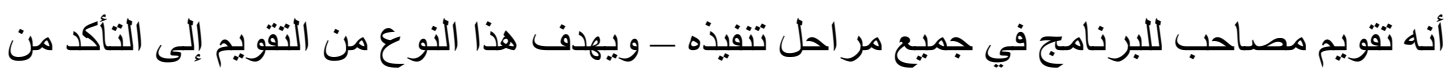

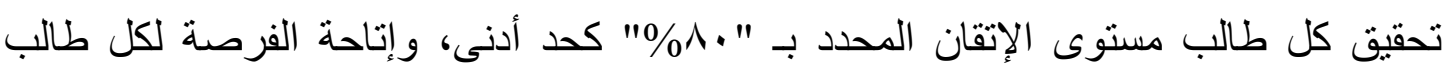


للانتقال إلى دراسة تعيين نال، وتقديم التغذية الراجعة لكل متدرب إذا أخفق في بلوغ مستوى

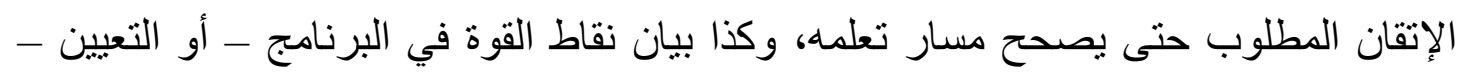

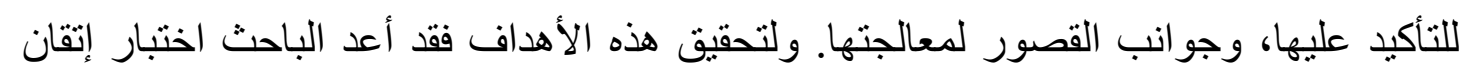

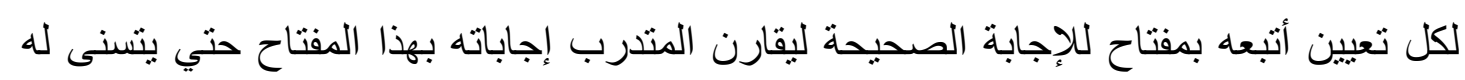
تقييم أدائه تقييما ذاتيا موضو عيا.

ـ التقويم النهائي "الختامي، التجميعي": ويكون بعد الانتهاء من دراسة البرنامج ككل، ويهذف

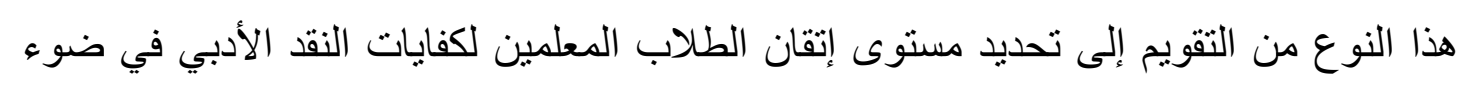

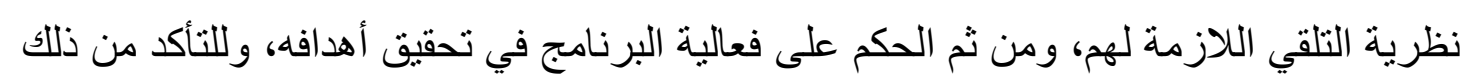
أعبد تطبيق الاختبار الذي استخدم في التقويم القبلي.

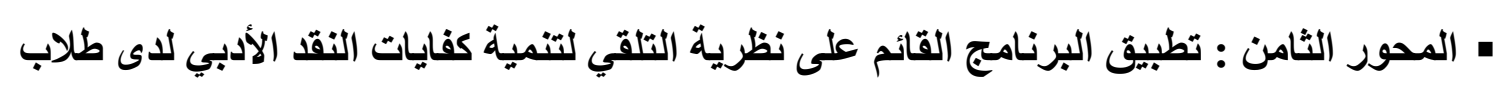
شعبة اللغة العربية بكليات التربية : تم تتفيذ التجربة الميدانية للبرنامج المقترح في الدراسة الحالية وفقا لمجموعة من

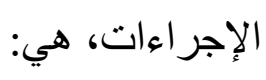

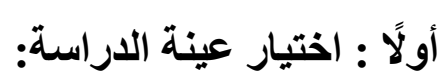
تم تطبيق البرنامج على عينة من طلاب وطالبات الفرقة الرابعة عام شعبة اللغة العربية

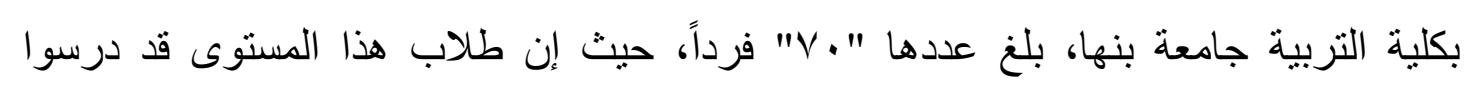

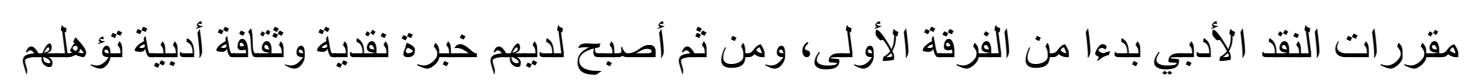

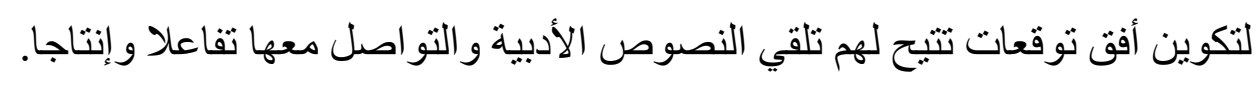
ثانيًا : تحديد التصميم التجريبي: انطلاقاً من جِّةّة البرنامج التدريبي المقترح في الدر اسة الحالية، وحداثته في ميدان تعليم كفايات النقد الأدبي في ضوء نظرية التلقي لطلاب شعبة اللغة العربية بكلبات التربية، وباعتباره البرنامج الوحيد و الفريد المر اد تجريبه وقياس فعاليته وتقويم أثره؛ فقد استخدم تصميم المجمو عة الواحدة؛ لأنه أفضل تصميم تجريبي يناسب طبيعة الدراسة الحالية ويحقق أهدافها.

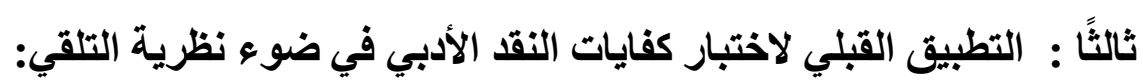

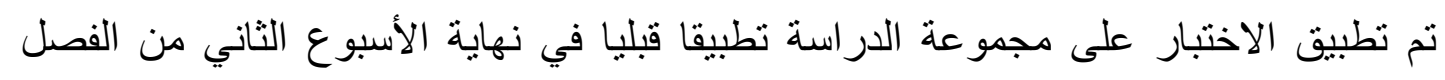

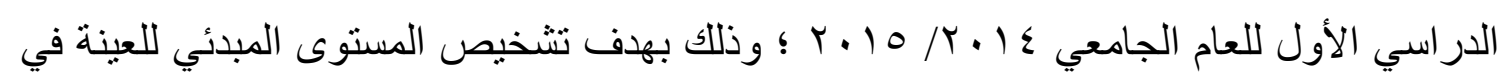




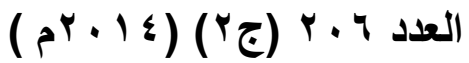 \\ مجلة دراسات في المناهج وطرق التدريس}

كفايات النقد الأدبي في ضوء نظرية التلقي اللازمة لهم ؛ والتحقق من صِحِّة الفَرْض الذي ينص على " يوجد تدني في مستوى تمكن طلاب شعبة اللغة العربية بكليات التربية من كفايات النقد الأدبي في ضوء نظرية التلقي اللازمة لهم ، وذلك في مجموع الكفايات ككل ، وفي كل كفاية نقدية على حده " ، وحتى يمثل ذلك نقطة الانطلاق في تنفيذ البرنامج المقترح في الدر اسة الحالية ، وبعد الانتهاء من التطبيق القبلي تم رصد البيانات ومعالجتها إحصائيا باستخدام البرنامج الإحصائي SPSS ، و الجدول التالي يوضح ذللك : ه

جدول ( r ) نتائج اختبار (ت) لتحديد مستوى تمكن أفراد العينة من كفايات النقد الأدبى ككل

\begin{tabular}{|c|c|c|c|c|c|c|}
\hline القيمة الاحتمالية & درجة الحرية & قيمة (ت) & الالحياري & المتوسط & التطبيق & العدد \\
\hline$\cdot, \ldots 1$ & 79 & $\Delta V, Y \otimes$ & $\bar{r}$ & $1 \cdot, 7$ & القبلي & $V$. \\
\hline
\end{tabular}

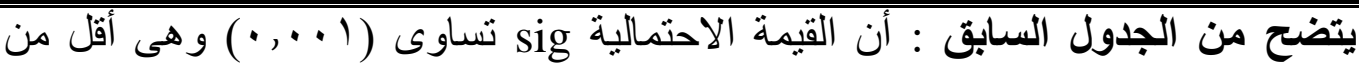

مستوى المعنوية (0 . , • ) و هذا يعنى أننا نقبل الفرض البديل الذى نص على وجود تدن في مستوى تمكن طلاب شعبة اللغة العربية بكلية التربية فى كفايات النقد الأدبى في ضوء نظرية التلقي اللازمة

$$
\text { لهم ، وذللك في مجموع الكفايات ككل. }
$$

ثم قام الباحث برصد البيانات القبلية الخاصة بكل كفاية نقدية فر عية على حده ، و الجدول التالي يوضتح ذللك :

جدول ( r ) نتائج اختبار (ت) لتحيد مستوى تمكن أفراد العينة من كل كفاية نقدية على حده

\begin{tabular}{|c|c|c|c|c|c|c|}
\hline 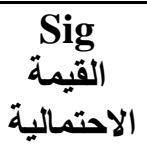 & 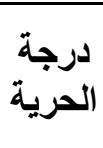 & قيمة (ت) & المعياري & المتوسط & التطبيق & الكفاية \\
\hline$\cdot, \cdots 1$ & 79 & $r \cdot, \wedge q$ & ., 74 &., 70 & القبلي & 1 - يحدد أفق توقعات العمل الأدبي . \\
\hline$\cdot, \cdots 1$ & 79 & $r T, 10$ & $\cdot, V \leq$ & $\cdot, 9 Y$ & القبلي & r-يقارن بين أفق انتظاره وأفق النص. \\
\hline$\cdot, \cdots 1$ & 79 & $r \wedge, 19-$ & $\cdot, V \cdot$ & $\cdot, 71$ & القبلي & "ץ-يعلل تغيير أفق انتظاره للنص. \\
\hline$\cdot, \cdots 1$ & 79 & $19, \wedge \vee=$ & $\cdot, \wedge \uparrow$ & $\cdot, 9 \leq$ & 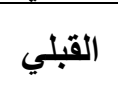 & بـ يستتنج المسافة الجمالية للنص من خلال \\
\hline$\cdot, \cdots 1$ & 99 & $r \cdot, I V$ & $\cdot, 71$ & $\cdot, \mathrm{VV}$ & 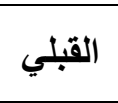 & النص ويطق آلية السؤال والجواب في بناء معانى \\
\hline$\cdot, \cdots 1$ & 79 & $14,7 \cdot-$ & $\cdot, \leqslant \leqslant$ & $\cdot r v$ & 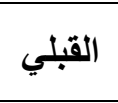 & 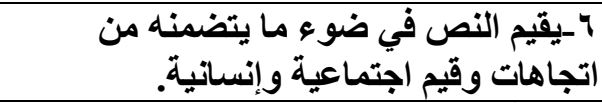 \\
\hline$\cdot, \cdots 1$ & $\cdot, 79$ & $\mu_{\Delta, \theta_{-}}$ & $\cdot, \mathrm{VV}$ & $1, \leqslant \wedge$ & لاقة. & إنتاج معناه. فَوات النص لإعادة بنائه و \\
\hline$\cdot, \cdots 1$ & 79 & $r_{\bullet, \Delta r_{-}}$ & $\cdot, V Y$ & 1,9 & القبلي & ^ـ-يستنتج علامات القارئ الضمني مبينًا \\
\hline
\end{tabular}

\section{\&}




\begin{tabular}{|c|c|c|c|c|c|c|}
\hline $\begin{array}{l}\text { Sig } \\
\text { الاحتمالية }\end{array}$ & 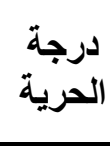 & قيمة (ت) & المعياري & المتوسط & التطبيق & الكفاية \\
\hline & & & & & & دورها في تأويل النص. \\
\hline$\cdot, \ldots 1$ & 7. & $r \mu, r \Lambda_{-}$ & $\cdot, \mathrm{Vr}$ & 1,90 & القبلي & 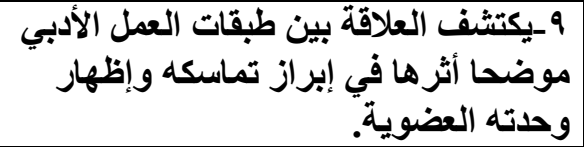 \\
\hline$\cdot, \ldots 1$ & 79 & $\mid v, \varepsilon \cdot-$ & 47 & 1,1 & القبلي & 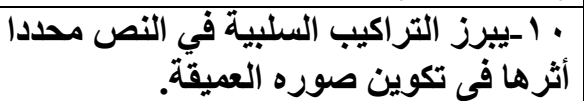 \\
\hline
\end{tabular}

يتضح من الجدول السابق: أن القيمة الاحتمالية sig تساوى ( (.., • ) وهى أقل من مستوى

المعنوية (0. . • ) و هذا يعنى أننا تقبل الفرض البديل الذى نص على وجود تدن في مستوى تمكن طلاب شعبة اللغة العربية بكلية التربية فى كفايات النقد الأدبى في ضوء نظرية التلقي اللازمة لهم ، وذلك في كل كفاية نقدية على حده. وتؤكد هذه النتيجة المبررات التي انطلقت منها الدراسة الحالية

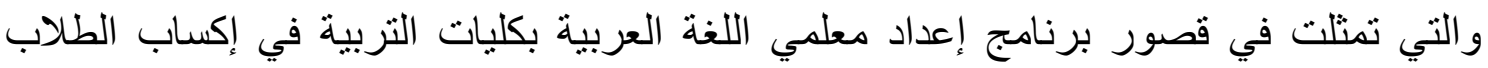
كفايات النقد الأدبي اللازمة لهم في ضوء نظرية التلقي ، كما تتفق هذه النتيجة مع نتائج بعض

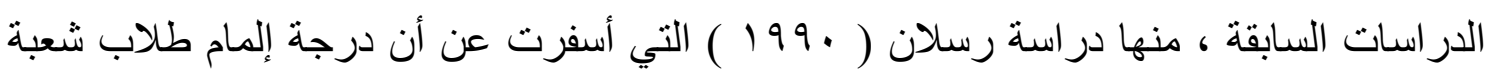

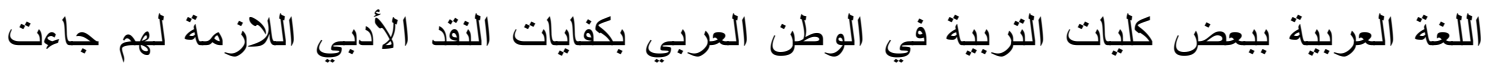

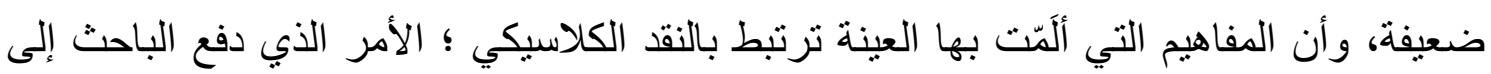
ضرورة تنفيذ البرنامج المقترح في الدراسة الحالية لإكساب طلاب شعبة اللغة العربية بكليات التربية كفايات النق الأدبي اللازمة لهم في ضوء نظرية التلقي.

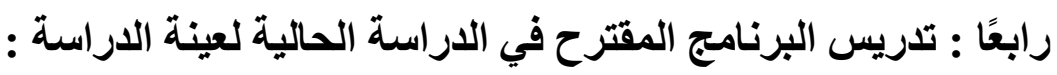

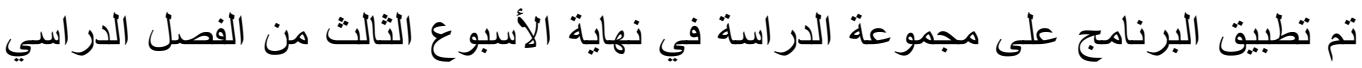

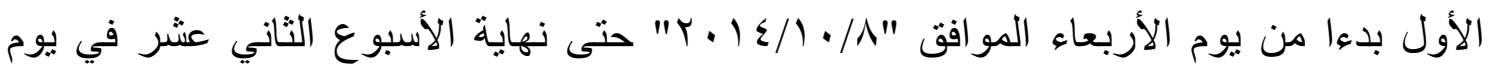

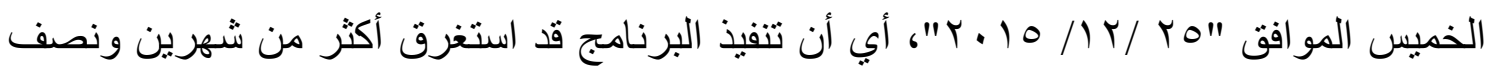
الثهر، كما أتاح الباحث أسبوعا آخر لبعض الطلاب المعلمين الذين لم يحققوا مستوى الإتقان

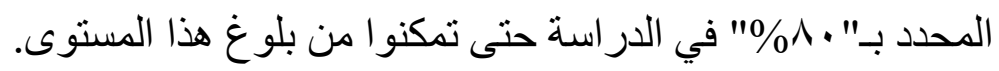

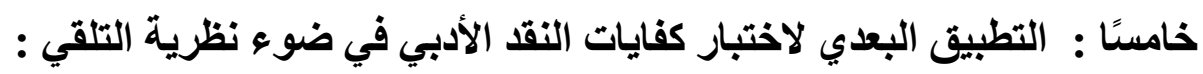

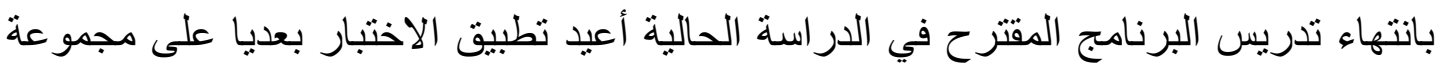

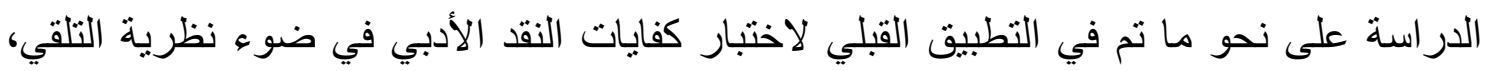


وذللك في يوم السبت الموافق "ب/10/1 ـ ץ"، وقد نم رصد البيانات ومعالجتها إحصائيا باستخدام البرنامج الإحصائي Spss لاستخلاص ما تسفر عنه الدراسة من نتائج.

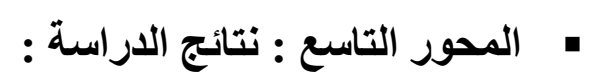

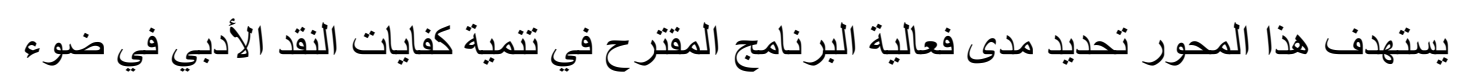
نظرية التلقي لدى طلاب شعبة اللغة العربية بكلبات التربية ، ورصد أهم النتائج والتوصيات و المقترحات التي أسفر عنها تطبيق البرنامج ؛ وتحقيقًا لكل ما سبق سيتم تناول الآتي :

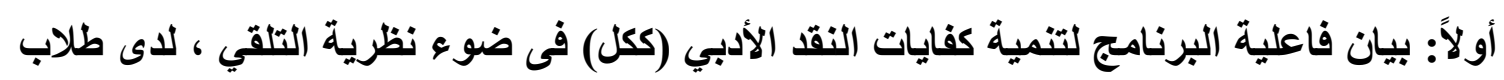
الفرقة الرابعة شعبة اللغة العربية بكلية التربية : تمت صياغة الفرض الخاص بهذا الجزء على النحو التالي : " توجد فروق ذات دلالة إحصائية عند مستوى (0. . . •) بين متوسطى درجات طلاب شعبة اللغة العربية فى اختبار كفايات النقد الأدبى ( ككل ) في ضوء نظرية التلقي قبليًا وبعديًا لصالح التطبيق البعدي.

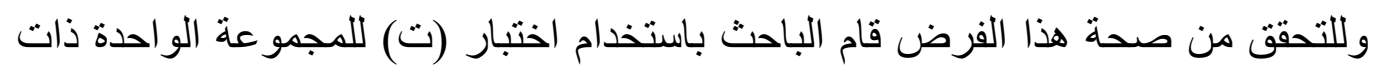

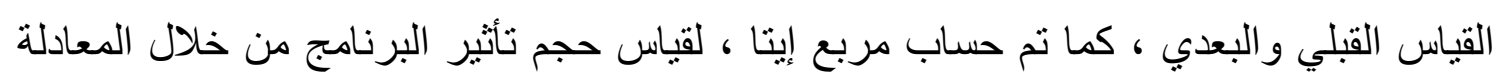

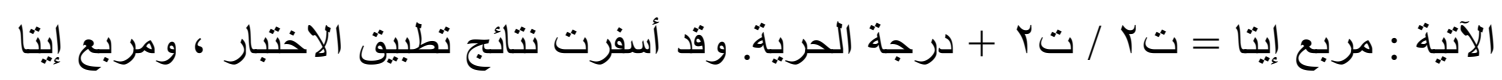

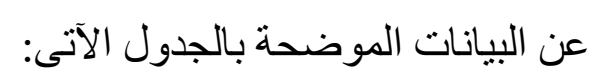

جدول ( ؛ ) نتائج اختبار (ت ) وحجم التأثير لتحديد دلالة الفروق بين درجات أفراد العينة في التقويمين القبلي و البعدي لكفايات النقا الأدبي ككل

\begin{tabular}{|c|c|c|c|c|c|c|c|}
\hline التأثبر & مستوي & قيمة (ت) & الدرجة & المعياري & المتوسط & التطبيق & العدد \\
\hline \multirow{2}{*}{$\cdot, 99$} & \multirow{2}{*}{$\cdot, .0$} & \multirow{2}{*}{ I } & \multirow{2}{*}{79} & $\begin{array}{r} \\
\end{array}$ & $1 \cdot, 7 r$ & القبلي & \multirow{2}{*}{$v$. } \\
\hline & & & & $r, \leqslant 0$ & $0 q, \leqslant \xi$ & البعدي & \\
\hline
\end{tabular}

يتضح من الجدول السابق أن هناك فرقا ذا دلالة إحصائية عند مستوى (0., •) بين

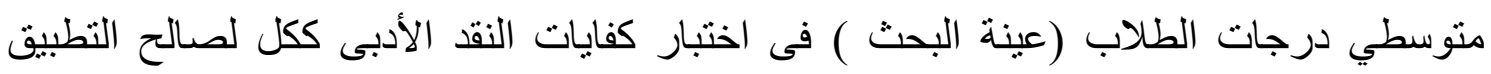

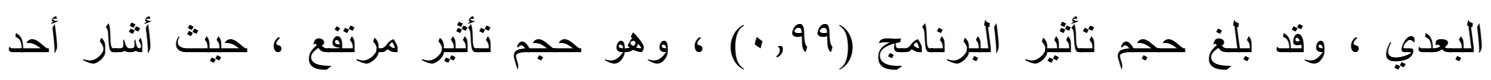

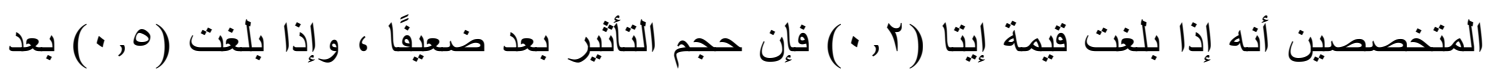

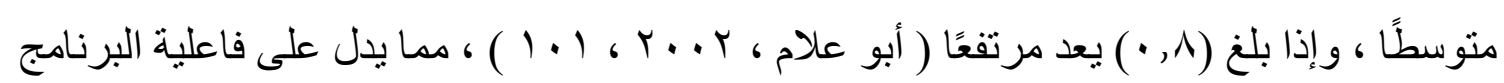


المقترح فى تتمية كفايات النقد الأدبى في ضوء نظرية التلقي لاى طلاب الفرقة الر ابعة عام شعبة اللغة العربية ( عينة الدراسة ).

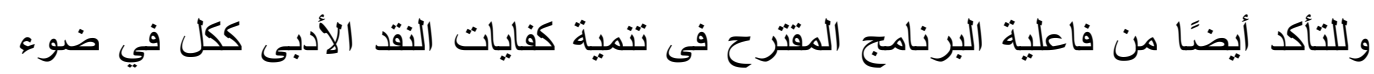

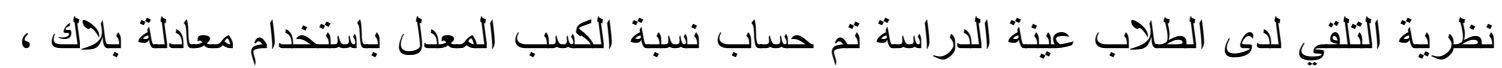
وهى:

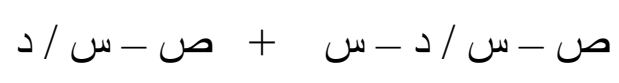

حيث ص = متوسط درجات الطلاب فى التطبيق البعدي. س = متوسط درجات الطلاب فى التطبيق القبلي. د = النهاية العظمى لدرجات الاختبار.

جدول (•) نسبة الكسب المحقى لاراسة البرنامج المقترح

\begin{tabular}{|c|c|c|c|c|}
\hline الالالة & نسبة الكسب & النهاية العظمى & المتوسط البعدي & المتوسط القبلي \\
\hline مقبول & 1,01 & $v$. & $09, \leqslant \xi$ & T., \\
\hline
\end{tabular}

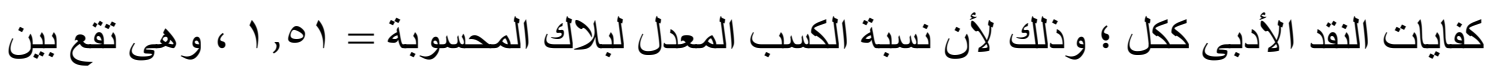

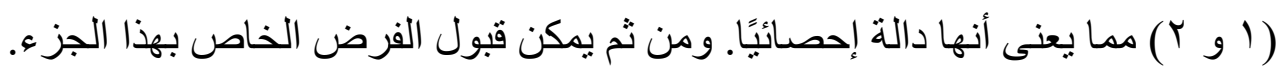

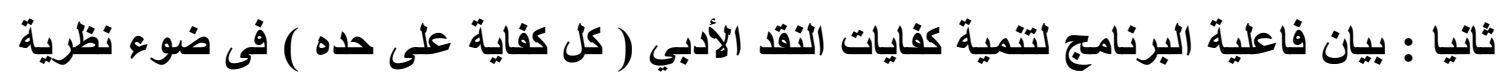
التلقي ، لاى طلاب الفرقة الرابعة شعبة اللغة العربية بكلية التربية:

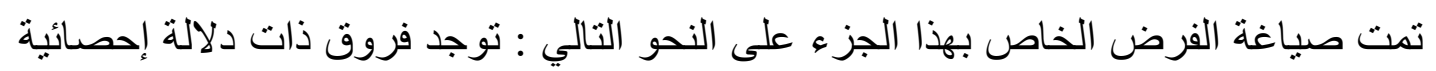

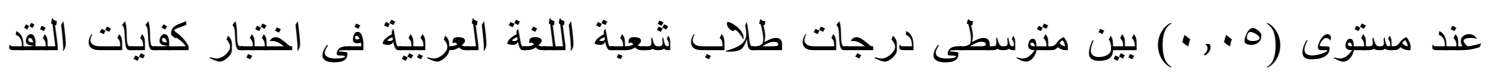
الأدبى ( في كل كفاية على حده ) في ضو و نظرية التلقي قبليًا وبعديًا لصالح التطبيق البعدي.

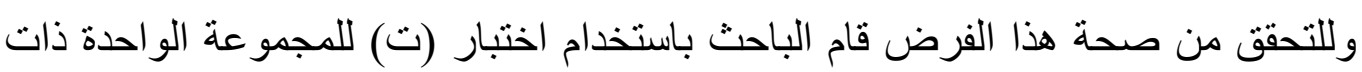

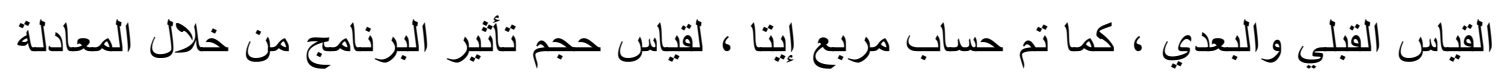

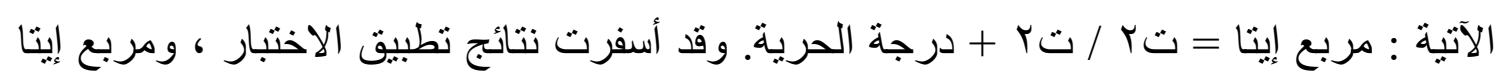

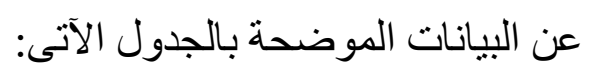




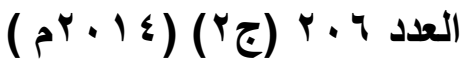
مجلة دراسات في المناهج وطرق التدريس

جدول ( 7 ) نتائج اختبار ( ت ) وحجم التأثير لتحديد دلالة الفروق بين درجات أفراد

العينة في التقويمين القبلي والبعدي لكل كفاية نقدية على حده

\begin{tabular}{|c|c|c|c|c|c|c|c|c|}
\hline الدولةع & التأثخي & مستوى & قيمة ت & الدرجة & الالانحراف & المتوسط & التطبيق & الكفاية \\
\hline \multirow{2}{*}{ إحصائية } & \multirow{2}{*}{$\cdot, 9 \mathrm{~V}$} & \multirow{2}{*}{$\cdot, \cdot 0$} & \multirow{2}{*}{$\Lambda V, \bullet \leq-$} & \multirow{2}{*}{79} & . & $\cdot, 70$ & القبلي & \multirow{2}{*}{ الأيحدي أفق توقعات العمل } \\
\hline & & & & & $\cdot, 0$ & $0, V \leqslant$ & البعدي & \\
\hline \multirow{2}{*}{ إحصائيا } & \multirow{2}{*}{$\cdot, 90$} & \multirow{2}{*}{$\cdot, \cdot 0$} & \multirow{2}{*}{$\begin{array}{c} \\
T r, \varepsilon .\end{array}$} & \multirow{2}{*}{79} & $\cdot, \mathrm{V} \leqslant$ & $\cdot, 9 Y$ & القبلي & \multirow{2}{*}{ وأفيقارن النص بين أقق انتظاره } \\
\hline & & & & & $\cdot, 7 r$ & 0,7 & البعدي & \\
\hline \multirow{2}{*}{ إحصائيا } & \multirow{2}{*}{$\cdot 99$} & \multirow{2}{*}{$\cdot, \cdot 0$} & \multirow{2}{*}{$\leqslant r, 9 \Lambda_{-}$} & \multirow{2}{*}{79} & $\cdot, v$. & $\cdot, 71$ & القبلي & \multirow{2}{*}{ با-يطل تغيير أفق انتظاره } \\
\hline & & & & & $\cdot, \Delta Y$ & $0,0 \leq$ & البعدي & \\
\hline \multirow{2}{*}{ إحصائيا } & \multirow[b]{2}{*}{$\cdot, 9 \varepsilon$} & \multirow[b]{2}{*}{$\cdot, 0$} & \multirow[b]{2}{*}{$r_{0}, V r_{-}$} & \multirow[b]{2}{*}{79} & $\cdot, \wedge \uparrow$ & $\cdot, 9 \leqslant$ & القبلي & \multirow{2}{*}{ اللأسلو من خيستج المسافة بعض الجمالية } \\
\hline & & & & & $\cdot, 0$ & $0, V \leqslant$ & البعدي & \\
\hline \multirow{2}{*}{ إحصائيا } & \multirow[b]{2}{*}{$\cdot, 90$} & \multirow[b]{2}{*}{$\cdot, \cdot 0$} & \multirow[b]{2}{*}{ M,,$\nearrow_{-}$} & \multirow[b]{2}{*}{79} & $\cdot, 71$ & $\cdot, \mathrm{VV}$ & القبلي & \multirow{2}{*}{ 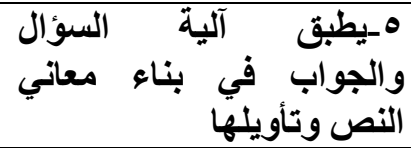 } \\
\hline & & & & & • & $r, \Lambda \varepsilon$ & البعدي & \\
\hline \multirow{2}{*}{ إحصائيا } & \multirow[b]{2}{*}{$\cdot, 9 r$} & \multirow[b]{2}{*}{$\cdot, \cdot 0$} & \multirow[b]{2}{*}{$r \wedge, r \varepsilon_{-}$} & & $\cdot, \leqslant \varepsilon$ & $\cdot, r V$ & القبلي & 7-يقيم النص في ضوء ما \\
\hline & & & & 79 & $\cdot, r \cdot$ & 1,90 & البعدي & اجتماعية وإنسانية من اتجاهات وقيم \\
\hline دال & & & & 79 & $\cdot, \mathrm{VV}$ & $1, \leqslant \wedge$ & القبلي & V-يملا فجوات النص لإعادة \\
\hline إحصائيا & $\cdot, 4 \lambda$ & $\cdot, \cdot 0$ & - & 79 & $\cdot, 0 \mathrm{~V}$ & 9,7 & البعدي & بنائه و إنتاج معناه \\
\hline & & & & & $\cdot, V Y$ & $1,9 \leq$ & القبلي & 1_-يستنتج ج علامات القارئ \\
\hline إحصائيا & $\cdot, 9 \mathrm{~V}$ & $\cdot, \cdot 0$ & $01,1 \Lambda_{-}$ & 79 & 1 & $q, r Y$ & البعدي & دورها في \\
\hline & & & & & $\cdot, V r$ & 1,90 & القبلي & 9 -يكتشف العلاقة بين طبقات \\
\hline إحصائيا & - 99 & $\cdot, \cdot 0$ & $\varepsilon \varepsilon, \mu V_{-}$ & 79 & $\cdot, \mathrm{TV}$ & $V, \varepsilon r$ & البعدي & 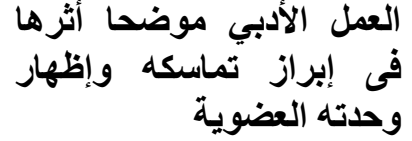 \\
\hline & & & & & $\cdot, 74$ & 1,1 . & القبلي & · ا-ييرز التراكيب السلبية \\
\hline إحصائيا & $\cdot, 9 \leqslant$ & $\cdot, \cdot 0$ & $m q, \cdot \varepsilon-$ & 79 & $\cdot, 09$ & \&, Tr & البعدي & فكوين النصور محددا أثُرها فى العميقة \\
\hline
\end{tabular}

يتضح من الجدول السابق وجود فروق ذات دلالة إحصائية عند مستوى (0. • •) بين متوسطى

درجات الطلاب عينة الدراسة فى اختبار كفايات النقد الأدبى ( لكل كفاية على حده ) في ضوء نظرية التلقي قبليًا وبعديًا لصالح التطبيق البعدي ، كما كان حجم التأثير مرتفعا لكل كفاية نقدية كالتالي :

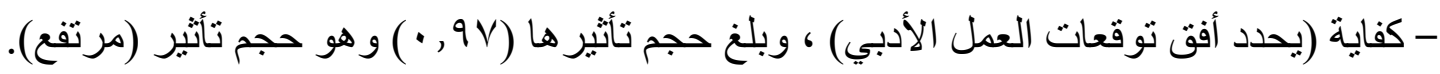
- وكفاية (يقارن بين أفق انتظاره و أفق النص) ، و وبلغ حجم تأثير ها (90 ، • •) وهو حجم تأثير (مرتفع). - وكفاية (يعلل تغيير أفق انتظاره للنص) ، وبلغ حجم تأثير ها (79 و ، •) وهو حجم تأثير (مرتفح). 
- وكفاية (بستنتج المسافة الجمالية للنص من خلال بعض الحيل الأسلوبية) وبلغ حجم تاثيرها

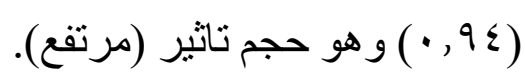

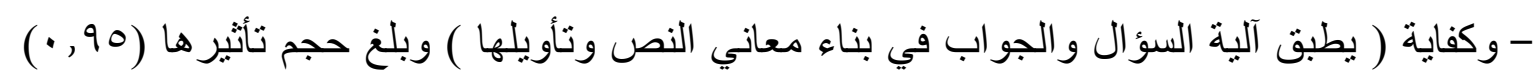
وهو نأثير ( مرتفع ). - وكفاية (يقيم النص فى ضوء ما يتضمنه من اتجاهات وقيم اجتماعية و إنسانية) وبلغ حجم تأثير ها

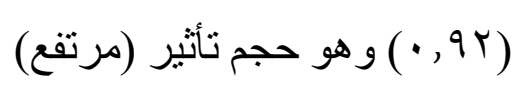

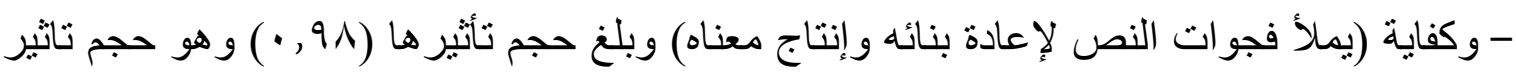

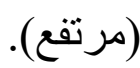
- وكفاية (بستنتج علامات القارئ الضمنى مبينًا دور ها فى تأويل النص) وبلغ حجم تأثثر ها ( و , • ) و هو حجم تاثثير (مرتفع). - وكفاية (يكتثف العلاقة بين طبقات العمل الأدبي موضحا أثرها فى إبراز تماسكه و إظهار وحدته العضوية) وبلغ حجم تأثير ها (7 9 , • ) و هو حجم ناثير (مرتفع).

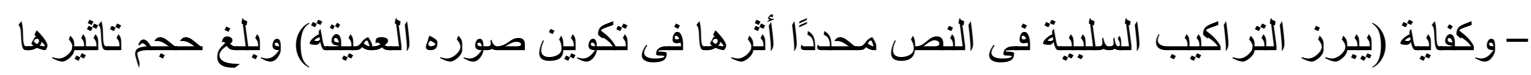

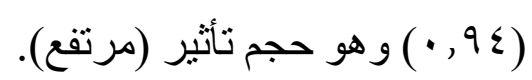

و هذا يعنى أنه قد حدث تحسن فى مستوى أداء الطلاب عينة الدهاب الدراسة فى كل كفاية على حده

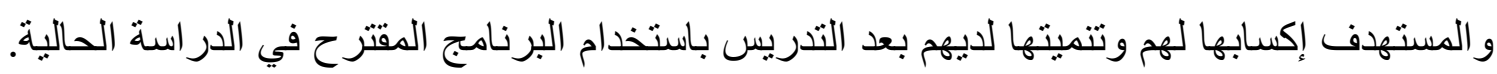

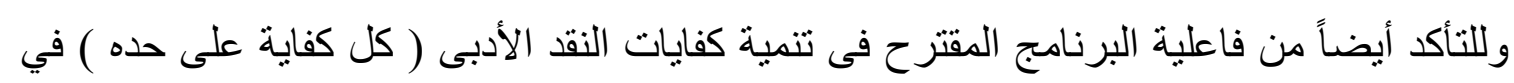

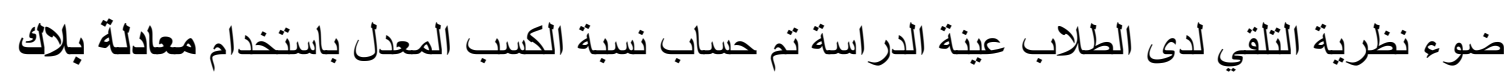

$$
\text { ص - س / د - س + ص - س / د }
$$

حيث: ص = متوسط درجات الطلاب فى التطبيق البعدي.

س = متوسط درجات الطلاب فى التطبيق القبلي. دـ النهاية العظمى لدرجات الاختبار.

\section{$1 \% q$}




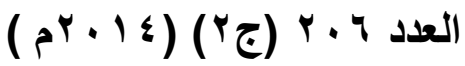
مجلة دراسات في المناهج وطرق التدريس

جدول ( V ) نسبة الكسب المحقق لكل كفاية نقدية على حده

\begin{tabular}{|c|c|c|c|c|c|}
\hline الدلالة & الكسبة & 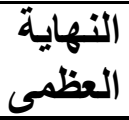 & البعدي & القبلئ المبط & الكفاية \\
\hline مقبول & $1, \sqrt{1,9}$ & 7 & $0, V \varepsilon$ & $\cdot, 10$ & 1-يحدد أفق توقعات العمل الأدبي. \\
\hline مقبول & $1, v$. & 7 & 0,7 . & $\cdot, 94$ & Y-يقارن بين أفق انتظاره وأفق النص. \\
\hline مقبول & $1, r v$ & 7 & $0,0 \leq$ & $\cdot, 71$ & r-يعلل تغيير أفق انتظاره للنص. \\
\hline مقبول & $1, v \leq$ & 7 & $0, V \leqslant$ & $\cdot, 9 \leq$ & بوض الحيتج الأسلوبة الجمالية للنص من خلال \\
\hline مقبول & $1, v_{1}$ & $\varepsilon$ & $\mu, \wedge \varepsilon$ & $\cdot, \mathrm{V} V$ & معاني النص آلية السؤال و والجواب في بناء \\
\hline مقبول & $1, \lambda 1$ & r & 1,90 & $\cdot, Y V$ & آجاهاهات وقيم اجتماعية و إنسانية. يتضمنه من \\
\hline مقبول & $1, \vee 7$ & 1 . & $9,7$. & $1, \leqslant \wedge$ & لمعناه. لمأ فجوات النص لإعادة بنائه وإنتاج \\
\hline مقبول & 1,70 & 1 . & $q, r Y$ & $1,9 \leq$ & 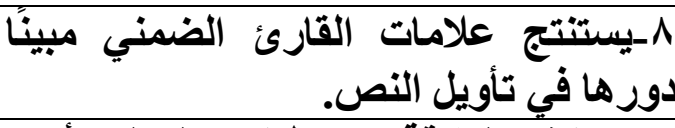 \\
\hline مقبول & 1,01 & $\Lambda$ & $V, \varepsilon Y$ & 1,90 & 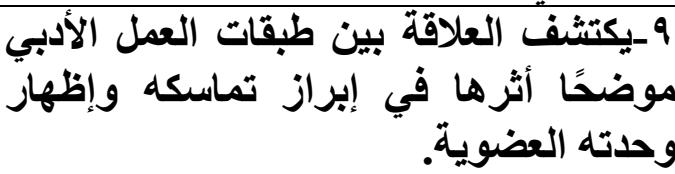 \\
\hline مقبول & 1,71 & • & $\varepsilon$ & 1,1 . & 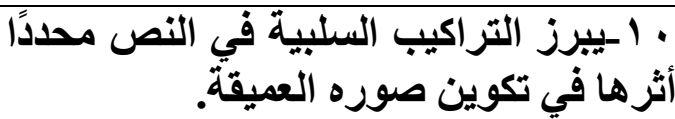 \\
\hline
\end{tabular}

يتضح من الجدول السابق أن البرنامج المقترح قد ساعد فى إكساب الطلاب عينة الدراسة

كفايات النقد الأدبى كل كفاية على حده ؛ وذلك لأن نسبة الكسب المعدل لبلاك المحسوبة لكل منها

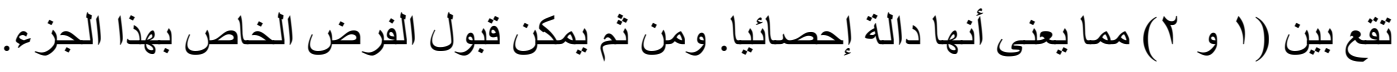

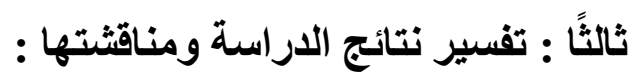
بما أن الدراسة الحالية قد توصلت إلى أن البرنامج المقترح ثبتت فاعليته في إكساب طلاب

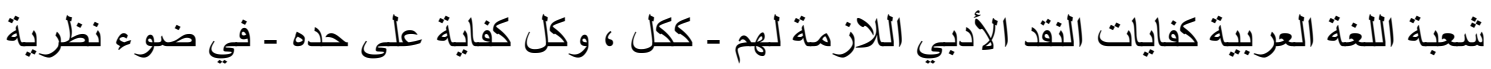

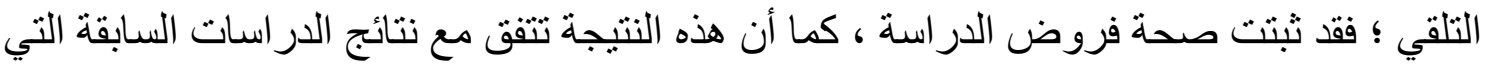

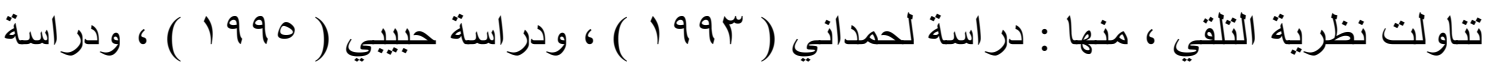

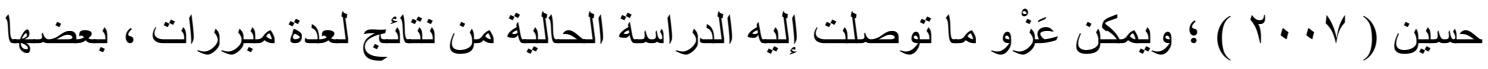
يتصل بنظرية التلقي ، وبعضها الآخر يرتبط بطبيعة البرنامج المقترح ، حيث أسهمت نظرية التلقي في تزويد الطلب المعلم بجملة من المفاهيم النقدية التي مكنته من ممارسة دوره كمستقبل

\section{$1 \leq$}


إيجابي ومُنْنِج باعتباره أحد أركان عملية التواصل الأدبي ، لا يقتصر دوره في الحكم على النص

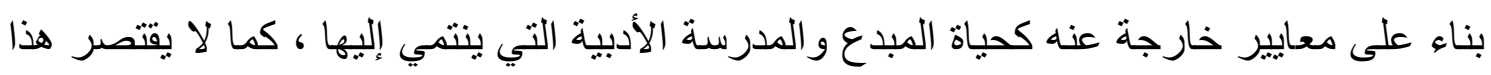
الدور في نقد العمل الأدبي على الثرح و التفسير والتذوق السطحي لبعض الألفاظ والأفكار

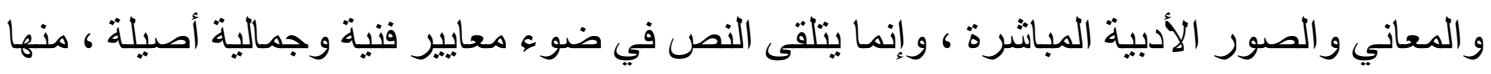

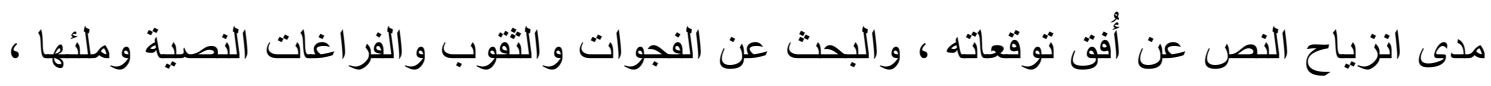

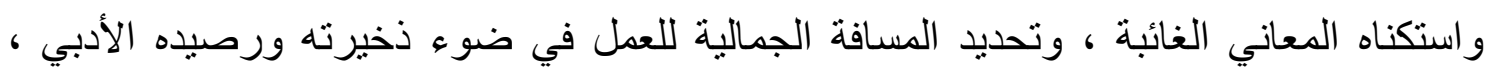

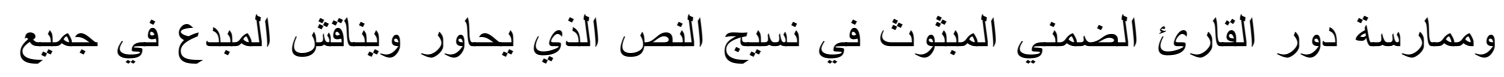

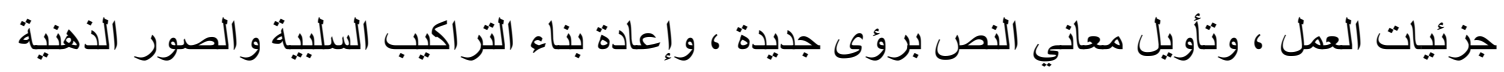

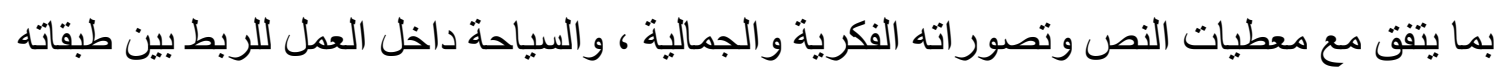
و إبر از مدى تماسكه فنيا ودلاليا. كما أن البرنامج المقترح الذي أعدته الدراسة الحالية بما تضمنه من عناصر ومكونات ، فقد

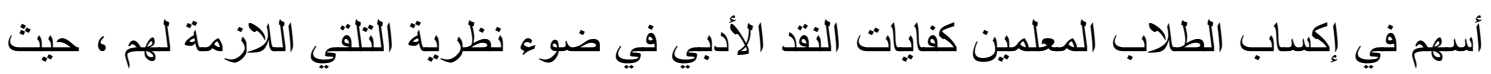

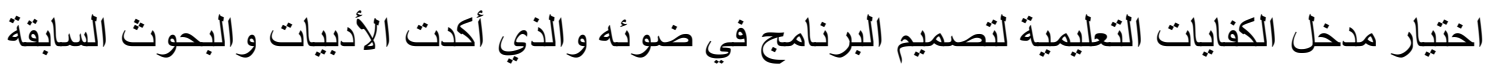
فعاليته في إعداد المعلمين وتدريبهم ، وتنظيم محتوى البرنامج في صورة تعيينات تدريبية ، تتميز باحتو ائها على عناصر كاملة وذاتية في المحتوى ، مع الارتباط المتصل ببقية التعيينات ، وتركيز

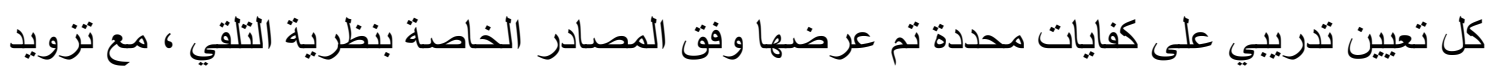

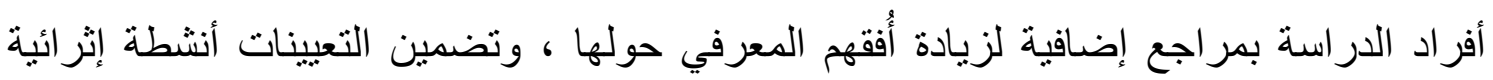

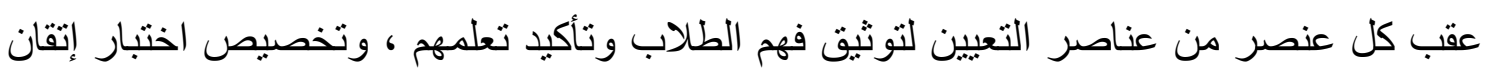

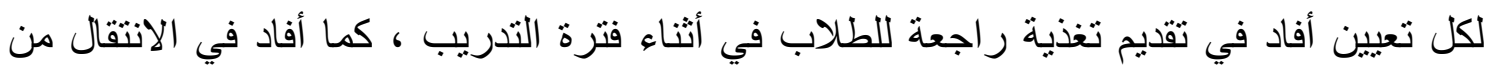

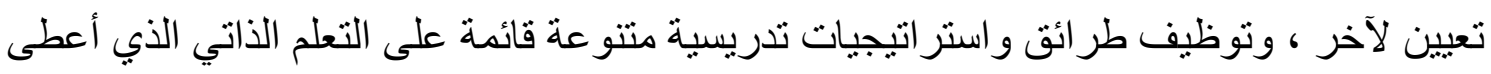
كل متدرب حرية الدراسة في الوقت الذي يناسبه وبالسر عة التي يستطيعها ، كما أن تنويع تعيينات

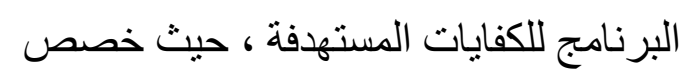

تعيينان تدرييان لإكساب الطلاب المعلمين الكفايات النظرية الخاصة بمفاهيم النقد الأدبي في ضوء

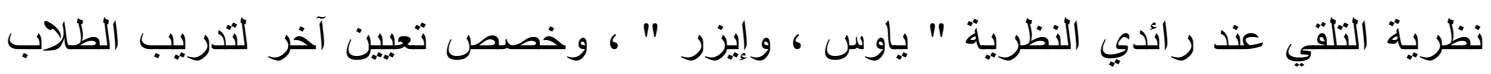

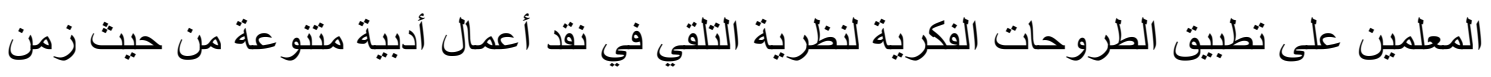
تلقيها ، أسهم في زيادة دافعية أفراد الدر اسة لاكتساب الكفايات المستهدفة. 


\section{رابعًا : توصيات الاراسة:}

في ضوء ما أسفرت عنه الدر اسة الحالية من نتائج يمكن تقديم التوصيات و التوجهات التالية: ـ تضمين مقرر ات النقد الأدبي لطلاب شعبة اللغة العربية بكليات التربية النظريات و المناهج النقدية

المعاصرة و التي من أهمها نظرية التلقي، و عدم الاقتصار على المناهج النقدية الكلاسيكية.

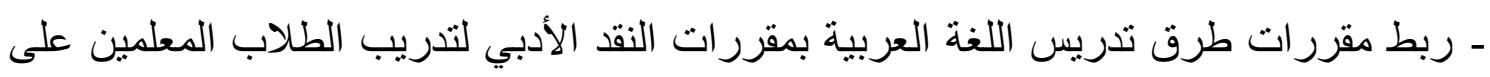
توظيف إجر اءاتها في تلقي الأدب و التفاعل معه إبداعاو إنتاجا. ـ تدريب الطلاب المعلمين على فهم العلاقات والصلات التي نربط بين نظرية التلقي والمناهج

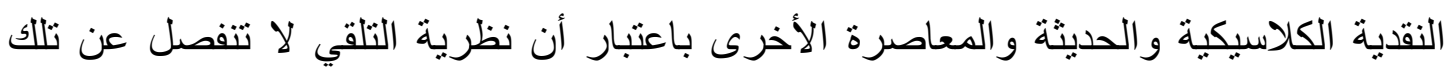

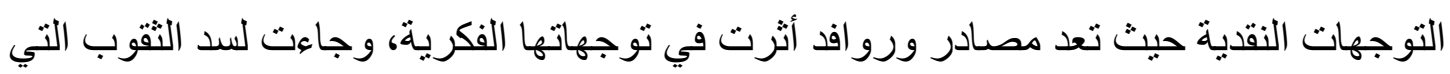

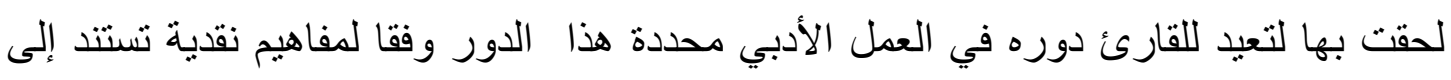
مسلمات وضو ابط علمية رصينة. ـ تدريب الطلاب المعلمين على نقد نصوص متنوعة من الآداب الأجنبية المترجمة والإبداعات العربية شعر ا ونثرا في ضو هو نظرية التلقي لصقل تقافتهم النقدية والأدبية. ـ تبصير الطلاب المعلمين بأن نظرية التلقي لها أصولها في الفكر النقدي العربي القديم وكذا في التراث الإسلامي، مع التطبيق على ذللك من خلال عرض مواقف نقدية مثل حلقات النقد في أسو اق عكاظ و البصرة والكوفة، و عرض مؤلفات كبار النقاد، مثل: الموازنة بين شعر أبي تمام

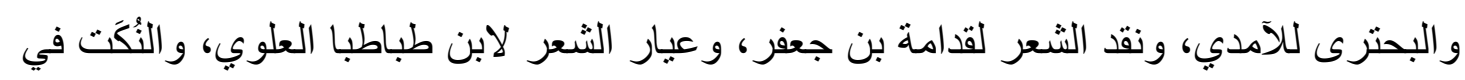

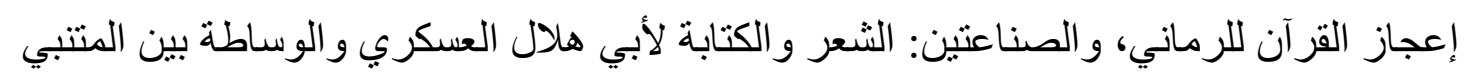

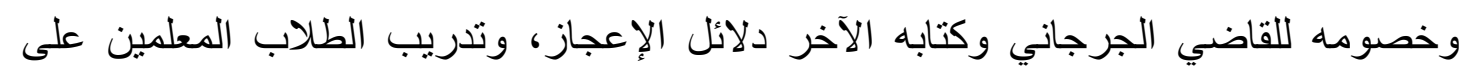

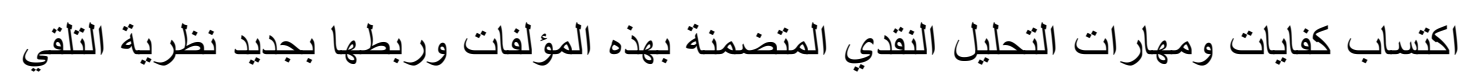
الألمانية. ـ عقد ندوات أدبية يُدَعَى لها بعض النقاد و الثعر اءه و الكُتَّاب لعرض تجاربهم النقدية والإبداعية

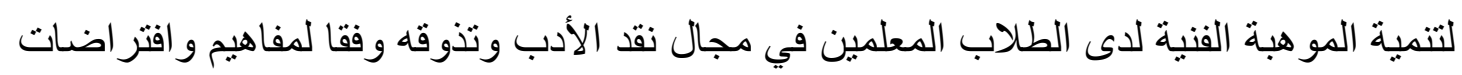
نظرية التلقي. ـ دعم الكفايات و المهار ات النقدية في ضوء نظرية التلقي لدى الطلاب المعلمين وملاحظة أدائهم التدريسي لتلاك الكفايات و المهار ات في أثناء تدريهم الميداني بمدارس التعليم العام. 


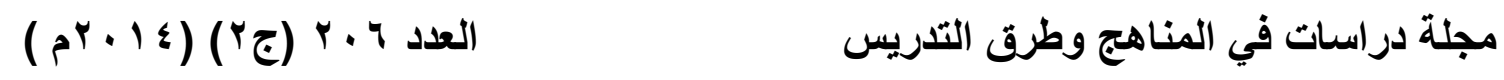

خامسًا : مقترحات الاراسة :

في ضوء ما توصلت إليه الدراسة الحالية من نتائج وما قدمته من توصيات يمكن إجراء

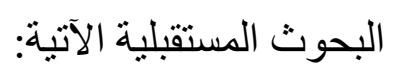

ـ تصور مقترح لتطوير بعض برامج إعداد معلم اللغة العربية بكليات التربية في ضوء نظرية التلقي.

ـ منهج مقترح في اللغة العربية لطلاب المرحلة الثانوية في ضوء نظرية التلقي لتنمية مهارات الإبداع اللغوي.

- برنامج مقترح لتنمية مهارات التذوق الأدبي لدى طلاب شعبة اللغة العربية بكليات التربية في ضوء نظرية التلقي.

- برنامج مقترح لتنمية كفايات تلقي النص القرآني وتدريسه لدى طلاب شعبة اللغة العربية بكليات التربية.

- برنامج مقترح لتتمية مهار ات القراءة و الكتابة لدى طلاب شعبة اللغة العربية بكليات التربية في ضو نظرية التلقي. 


\section{قــــائمة المراجـع}

ـ أبو علام، رجاء محمود (991 (1)): "مناهج البحث في العلوم النفسية والتربوية "، طس، القاهرة: دار النشر للجامعات.

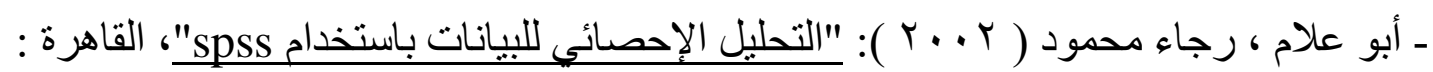
دار النشر للجامعات.

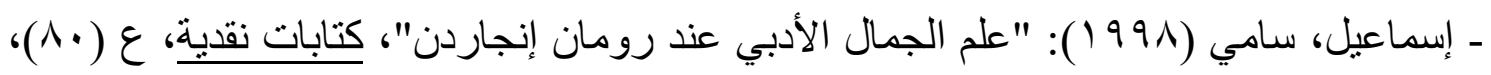
القاهرة: الهيئة العامة لقصور الثقافة.

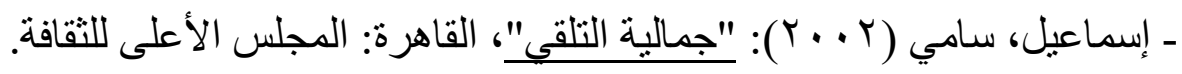

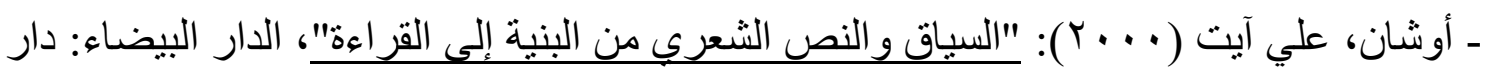
الثقافة للنشر و التويع. - إيبانوكس، خوسيه ماريا بوثويلو (1991): "نظرية اللغة الأدبية"، ترجمة: حامد أبو أحمد، القاهرة: مكتبة غريب.

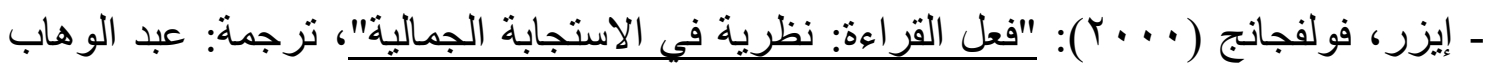
علوب، القاهرة: المجلس الأعلى للثقافة.

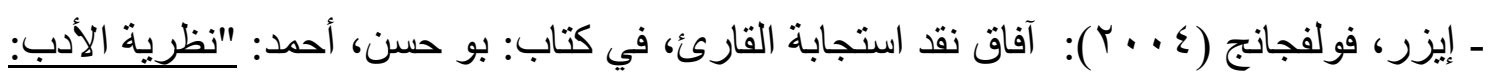

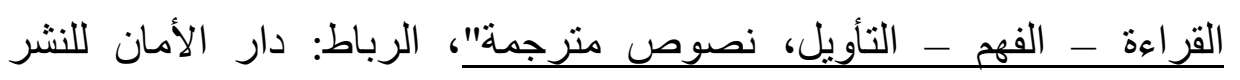

$$
\text { و التوزيع. }
$$

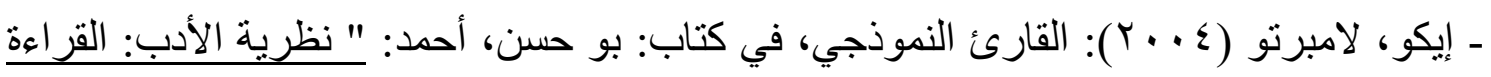

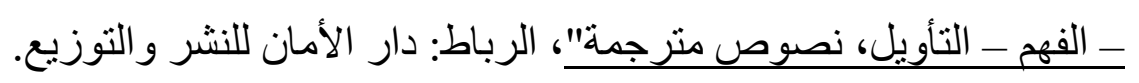

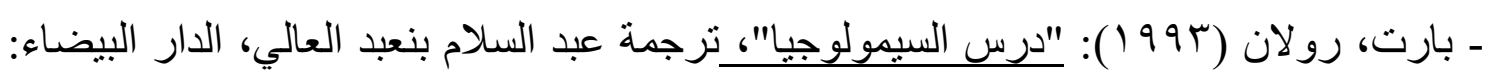

$$
\text { دار توبقال. }
$$

- بلخامسة، كريمة (11) (1)): "إنثكالية التلقي في أعمال كاتب ياسين"، رسالة دكتور اه، غير

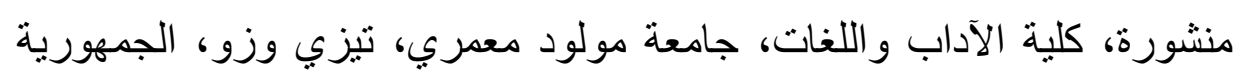

$$
\text { الجز ائرية الديمقر اطية الشعبية. }
$$

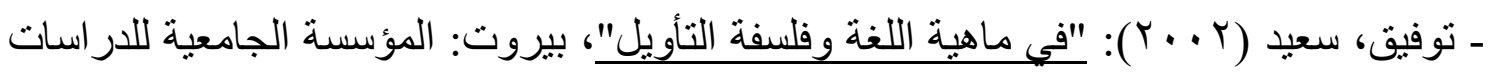

$$
\text { و النشر. }
$$

\section{$1 \leq \varepsilon$}


ـ الجودي، لطفي فكري محمد (1) ب. (1): "النص الثعري بوصفه أفقا تأويليا: قراءة في تجربة التأويل الصوفي عند محي الدين بن عربى، ديوان ترجمان الأشواق نموذجاً"،

$$
\text { القاهرة: مؤسسة المختار للنشر و التوزيع. }
$$

- حبيبي، ميلود (بو99): "النص الأدبي بين التلقي وإعادة الإنتاج من أجل بيداغوجيا تفاعلية

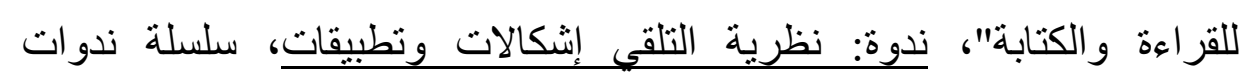

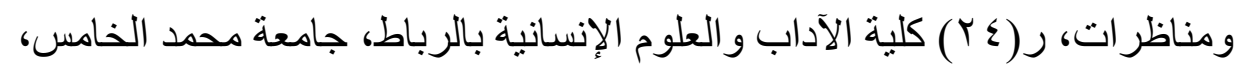

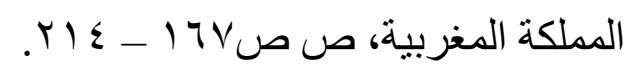
- حبيبي، ميلود (1990) : "بيداغوجية التلقي و استر اتيجيات التعلم: تلقي النصوص الأدبية بين تأثثر

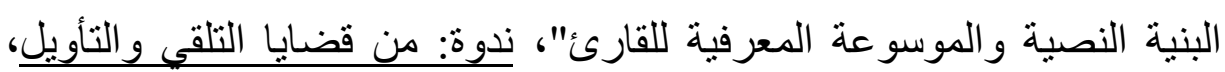

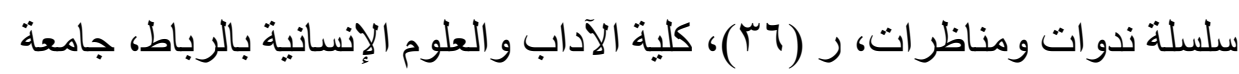

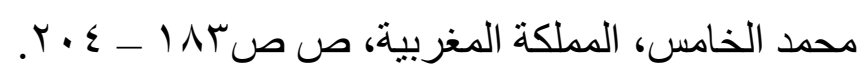

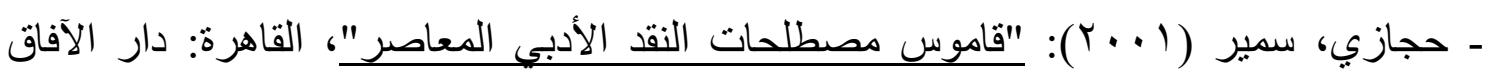
العربية.

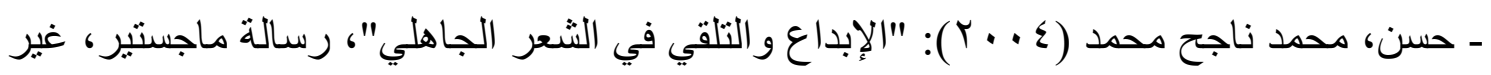
منشورة، كلية الدر اسات العليا، جامعة النجاح الوطنية بنابلس، دولة فلة فلسطين.

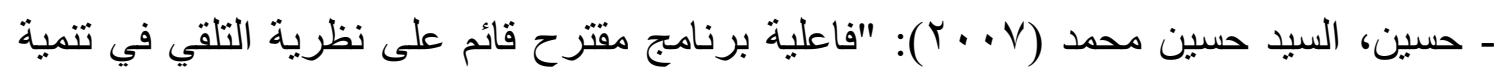

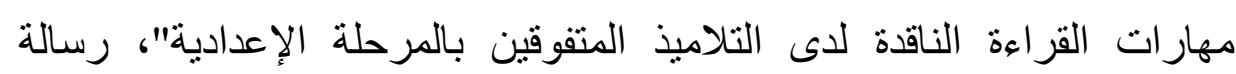
دكتور اه، غير منشورة، كلية التربية بدمياط جامعة المنصورة.

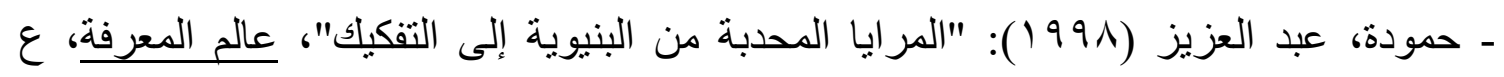

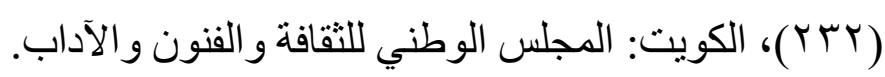
ـ خضر، ناظم عودة (Y99 (1): "الأصول المعرفية لنظرية التلقي"، عَمّان: دار الثروق للنشر و التوزيع.

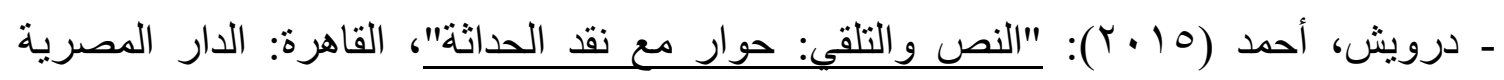
اللبنانية.

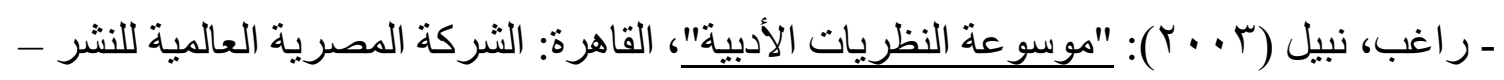
لونجمان. 
- رسلان، مصطفى (•199 (19): "كفايات النقد الأدبي لمعلم اللغة العربية"، المؤتمر العلمي الثاني

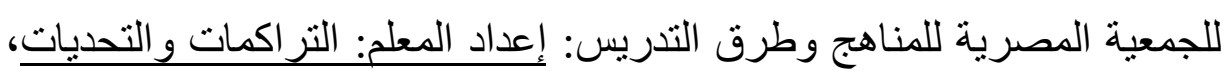

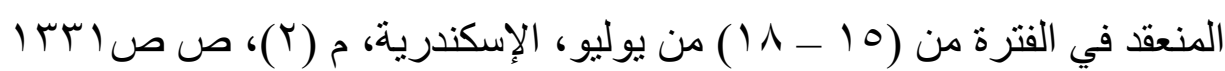
$.1400-$

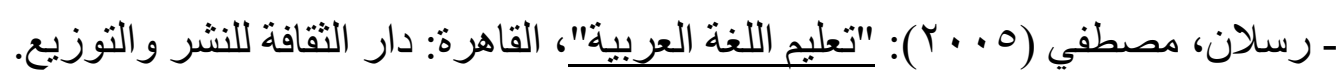

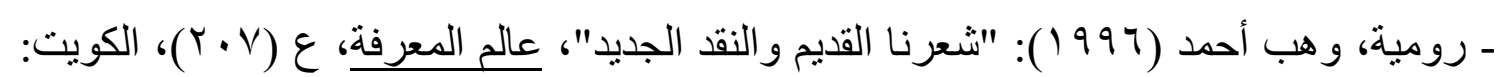
المجلس الوطني للتقافة و الفنون و الآداب.

ـ الرويلي ميجان، البازعي سعد (r +. r): "دليل الناقد الأدبي: إضاءة لأكثر من سبعين تياراً

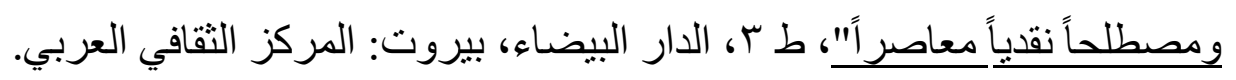

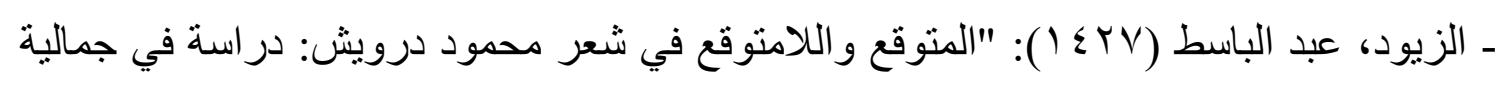

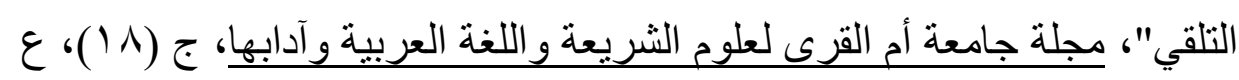

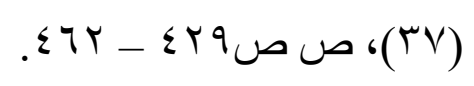

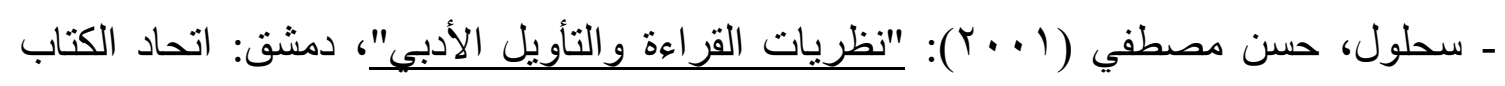

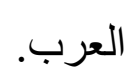

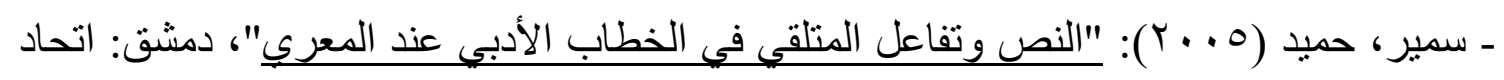

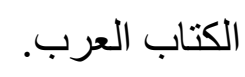

ـ السيد، فؤاد البهي (9>9 (1): "علم النفس الإحصائي وقياس العقل البشري"، طس، القاهرة: دار

$$
\text { الفكر العربي. }
$$

ـ شحاتة، حسن ( 1997 ) ): "تعليم اللغة العربية بين النظرية والتطبيق"، ط س، القاهرة: الدار

$$
\text { المصرية اللبنانية. }
$$

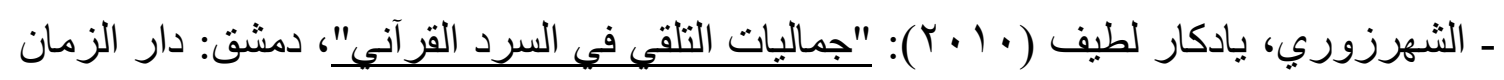

$$
\text { للطباعة والنشر و التوزيع. }
$$

ـ شوشة، فاروق (9 . . †): "سؤال الثعر"، الندوة الرئسية لمهرجان القرين الثقافي الثاني عشر:

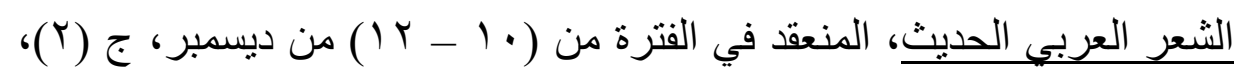

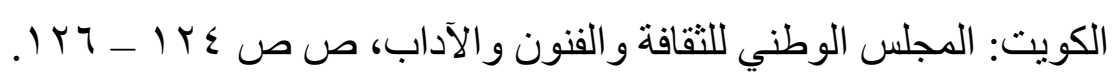

\section{$1 \leq 7$}




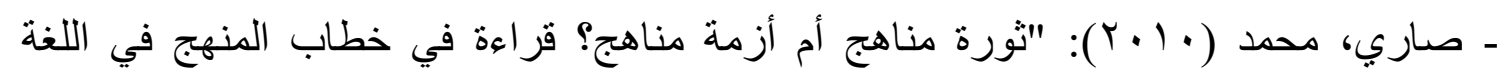

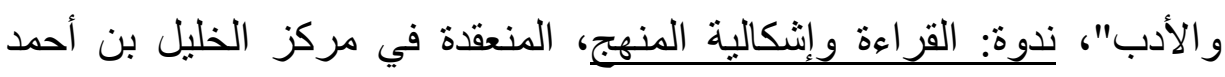

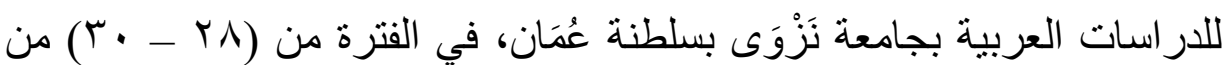

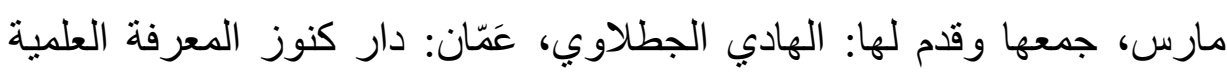

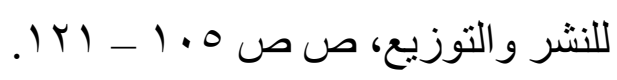

ـ الصكر ، حاتم (• • ؟ ): "موجهات القر اءة ومحددات التلقي: إجر اءات مقترحة وتطبيقات"، ندوة:

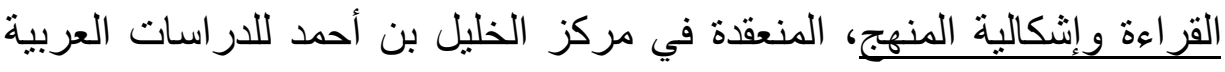

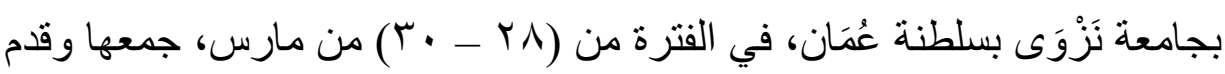

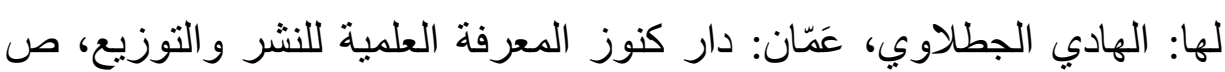

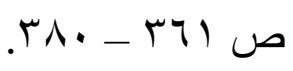

ـ طبانة ، بدوي (19V0 ) :" در اسات في نقد الأدب العربي من الجاهلية إلى نهاية القرن الثالث"

$$
\text { ، القاهرة : الأنجلو المصرية. (الني. }
$$

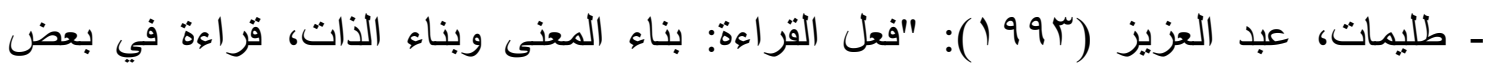
أطروحات ولفغانغ إيزر "، ندوة: نظرية التلقي إثكالات وتطبيقات، سلسلة ندوات اتهاه

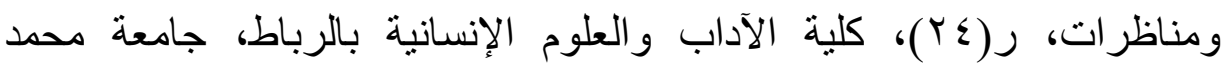

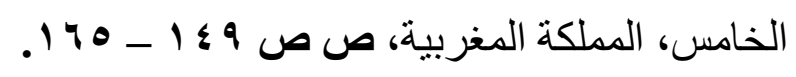

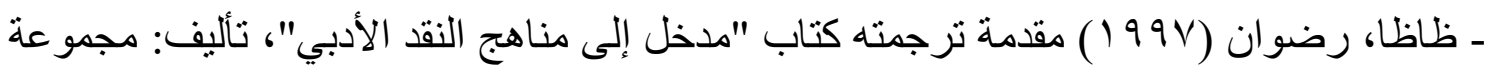

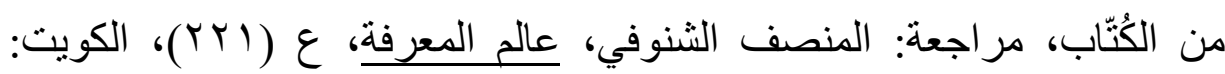

$$
\text { المجلس الوطني للتقافة و الفنون و الآداب. }
$$

ـ عامر، رمضان أحمد عبد النبي (د. ت) القارئ و أثره في تثكيل النص الأدبي: "قراعة في شعرنا

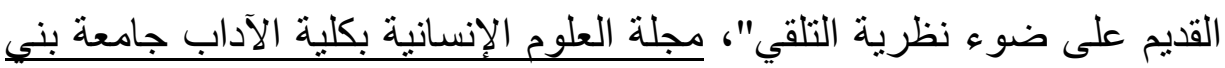

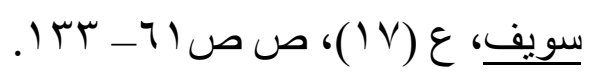

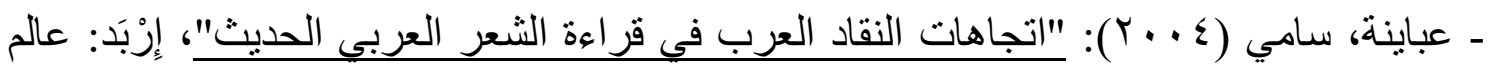

$$
\text { الكتب الحديث للنشر و التوزيع. }
$$

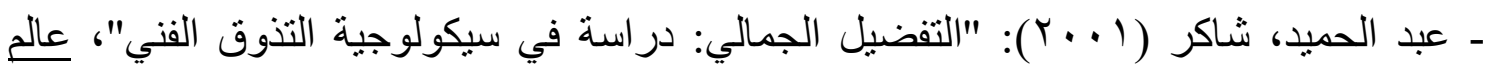

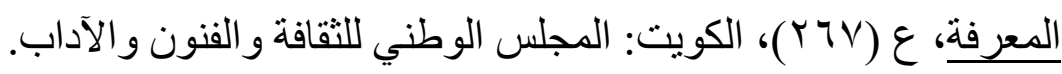


ـ عبد الو احد، محمود عباس (1997 ) : "قر اءة النص وجماليات التلقي بين الدذاهب الغربية الحديثة وتر اثنا النقدي: دراسة مقارنة"، القاهرة: دار الفكر العربي.

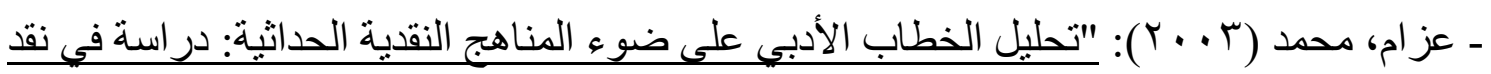
النقد"، دمشق: اتحاد الكتاب العرب.

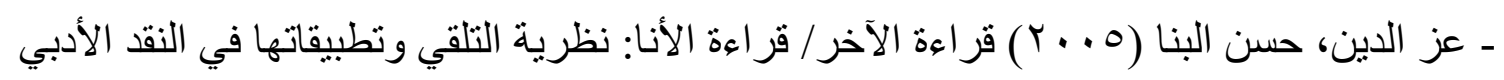

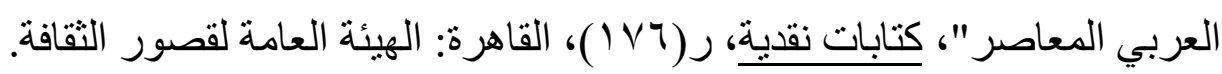

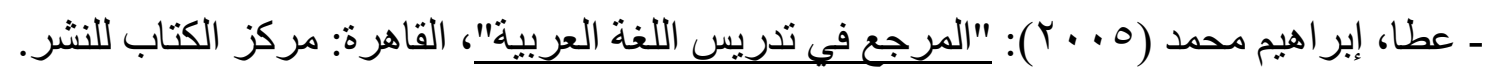

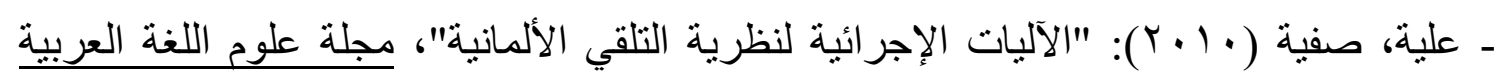

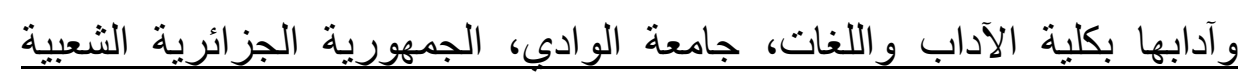

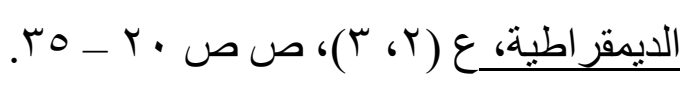

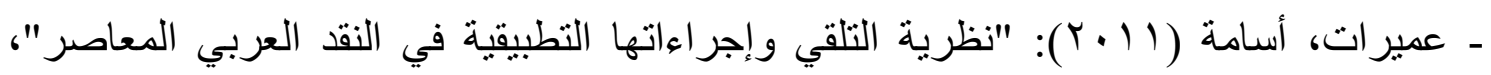
رسالة ماجستير، كلية الآداب و اللغات، جامعة الحاج لخضر - باتنة، الجمهورية

\section{الجز ائرية الثُعبية الديمقر اطية.}

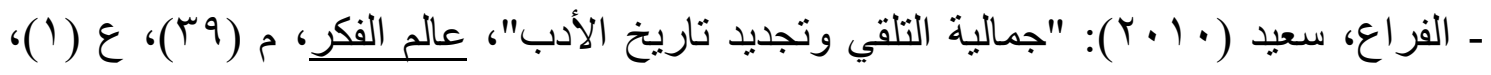

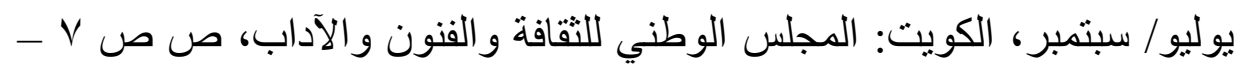

\section{r}

ـ فضل، صلاح (1991 (1): "علم الأسلوب: مبادئه و إجر اءاته"، القاهرة: دار الثروق.

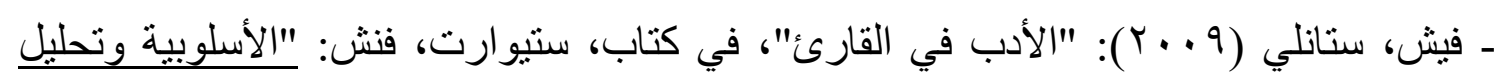
النص"، ترجمة: المركز الثقافي للتعريب و الترجمة، القاهرة: دار الكتاب الحديث.

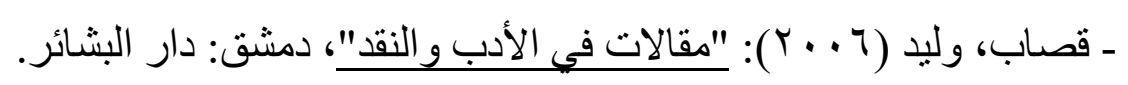

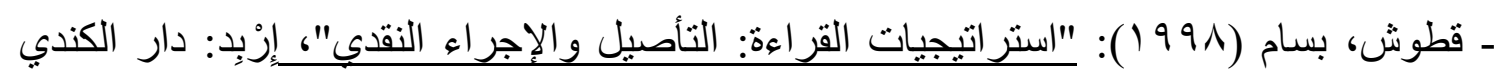

للنشر و التوزيع، ومؤسسة حمادة للخدمات و الدر اسات الجامعية.

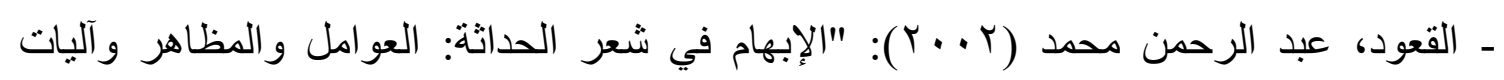

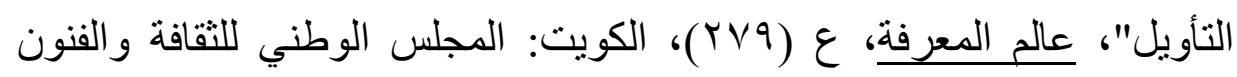

$$
\text { والآداب. }
$$


ـ كلية الآداب و العلوم الإنسانية بالرباط، جامعة محمد الخامس (ب999) ("ندوة نظرية التلقي إنشالات وتطبيقات، سلسلة ندو ات ومناظر ات، ر( ؟ ب)، المملكة المغربية. ـ كلية الآداب و العلوم الإنسانية بالرباط، جامعة محد الخامس (1990)): "ندوة من قضايا التلقي و التأويل"، سلسلة ندو ات ومناظر ات، ر ( حب)، المملكة المغربية. ـ لحمداني، حميد (1991): "مستويات التلقي: القصة القصيرة نموذجاً"، ندوة: نظرية التلقي إنكالات، وتطبيقات سلسلة ندوات ومناظرات، ر (؟ع)، كلية الآداب و العلوم

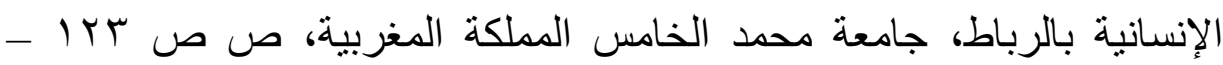
. I $\leqslant \vee$

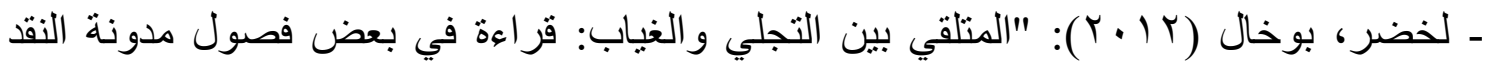

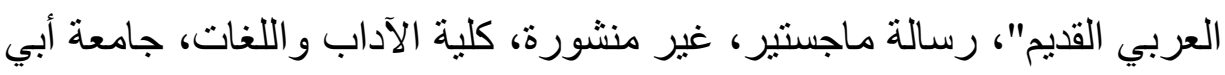
بكر بلقايد - تلمسان، الجمهورية الجزائرية الثعبية الديمقر اطية. ـ محمد، عبد الناصر حسن (999 (19): "نظرية التوصيل وقراءة النص الأدبى"، القاهرة: المكتب المصري لتوزيع المطبو عات. ـ المركز الثقافي للنعريب و الترجمة (9 . . ب) مقدمة ترجمته كتاب، "الأسلوبية وتحليل النص"ك إعداد: ستيوارت فنش، القاهرة: دار الكتاب الحديث.

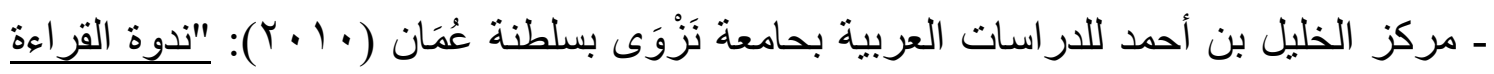

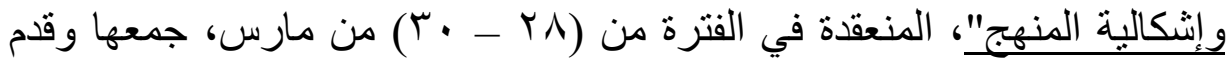

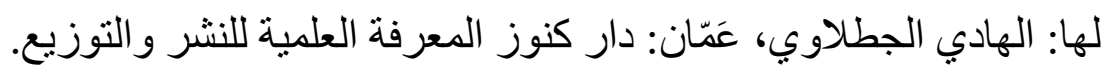

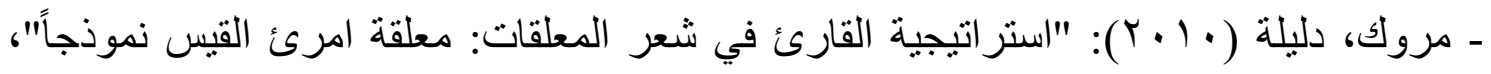

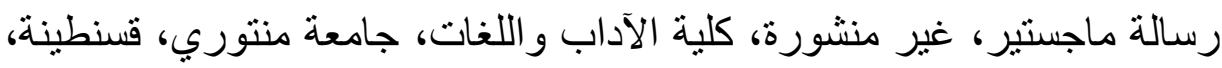
الحمهورية الجزائرية الثعبية الديمقر اطية.

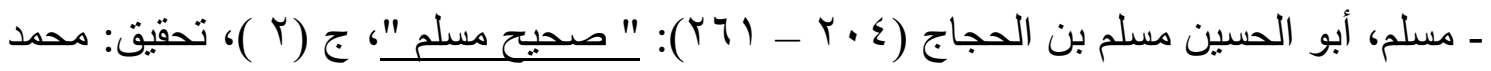

$$
\text { أحمد عيسى، القاهرة: دار الرحاب. }
$$

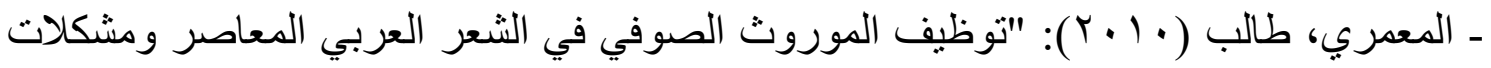

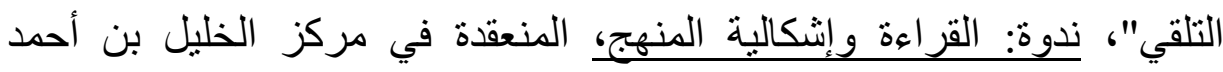

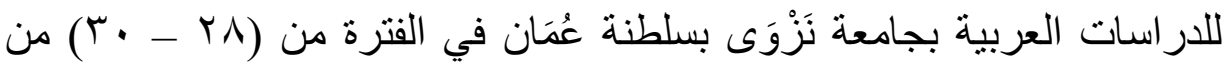


مارس، جمعها وقدم لها: الهادي الجطلاوي، عَمّان: دار كنوز المعرفة العلمية

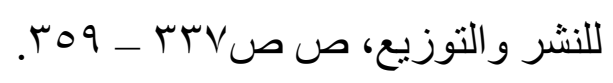

ـ الموسى، خليل (• (†)): "آليات القراعة في الثعر العربي المعاصر"، دمشق: الهيئة العامة

السورية للكتاب.

ـ ناجي، آلاء داود محمد (11 + Y): "شعر أبي القاسم الثابي في ضوء نظرية التلقي"، رسالة

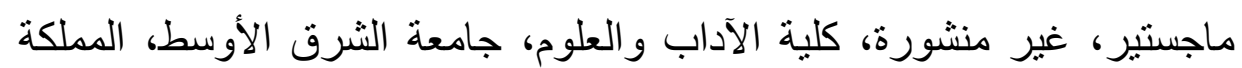

$$
\text { الأردنية الهاشمية. }
$$

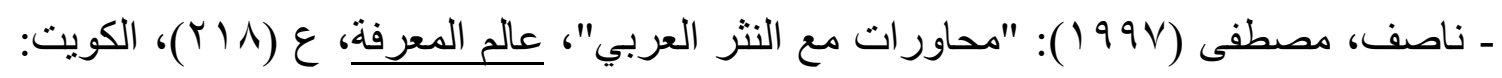
المجلس الوطني للثقافة و الفنون والآداب.

ـ الناقة ، محمود كامل ( 997 ( ):"البرنامج التعليمي القائم على الكفاءات : أسسه ، و إجر اءاته" ، ط ب ، القاهرة : سعد سمك للطباعة و النسخ.

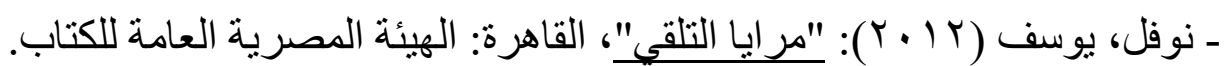

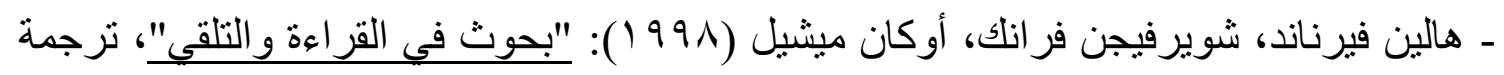
وتقديم وتعليق: محمد خير البقاعي، حَلَب: مركز الإنماء الحضاري.

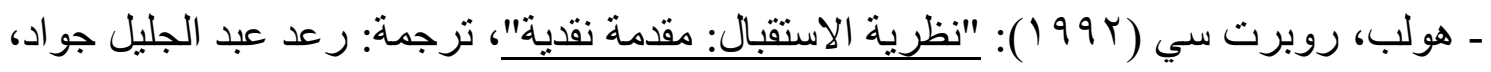

$$
\text { اللاذقية: دار الحوار للنشر والتوزيع. }
$$

ـ هولب، روبرت سي (ع 99 (1): "نظرية التلقي: مقدمة نقدية"، ترجمة: عز الدين إسماعيل، جِدّة:

$$
\text { النادي الثقافي الأدبي. }
$$

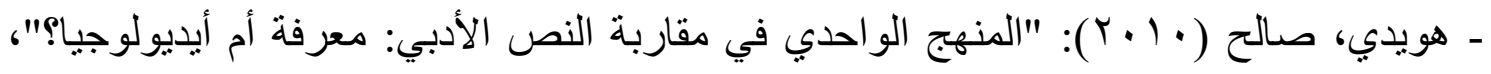

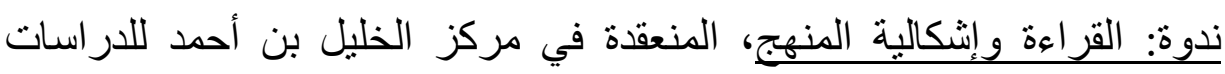

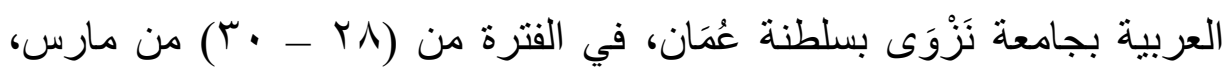

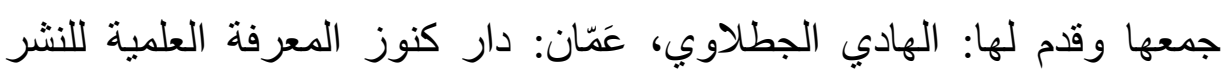

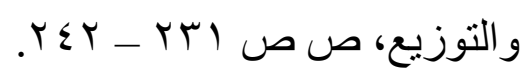

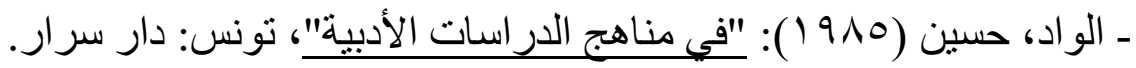

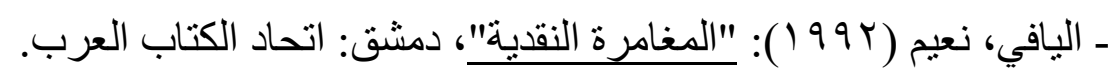




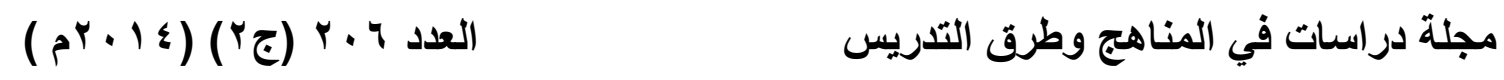

- ياوس، هانز روبرت (ع . ㄷ): "جمالية التلقى: من أجل تأويل جديد للنص الأدبى"، ترجمة وتقديم: رشيد بنحدو، القاهرة: المجلس الأعلى للثقافة.

- يونس فتحي، الناقة محمود كامل، طعيمة رشدي أحمد (9Av (19)): "تعليم اللغة العربية: أسسداه و إجر اءاته"، ج ( (1)، القاهرة: مطابع الطوبجي. 